\title{
HUNGARY
}

\author{
Károly Bárd*
}

\section{The Legal Order of Hungary and the European Convention on Human Rights}

\subsection{Hungary's Constitutional Order}

Although the country's official name was changed from Republic of Hungary to Hungary by the Fundamental Law $(\mathrm{FL})^{1}$ that replaced the previous Constitution ${ }^{2}$, this has not altered the form of government: Hungary is still a republic. [Article B (2)] The FL proclaims that "Hungary shall be an independent and democratic State under the rule of law" [Article B (1)] and that the State shall function on the basis of the separation of powers. [Article C (1)] The FL proclaims the principle of people's sovereignty and that the people exercise their power through their representatives, and also directly in exceptional cases. [Article B (3) and (4)]

The Fundamental Law forms the basis of the country's legal system. No law may be contrary to the Fundamental law. Review of legislation with regard to their conformity with the $\mathrm{FL}$ is in the exclusive competence of the Constitutional Court.

The Parliament is the supreme body of popular representation. [Article 1 (1)] Among the tasks of the body are the adoption of the FL and other acts, the adoption of the central budget, the election of the President of the Republic, the members and the President of the Constitutional Court, President of the Curia (Supreme Court), the Chief Public Prosecutor, and the Prime Minister. Further the Parliament decides upon the declaration of a state of war, and on the conclusion of peace. [Article 1 (2) a)-k)] The President of the Republic is the head of State of the country. The President's powers are relatively weak, however, he/she may initiate an Act of Parliament and national referenda. The President convenes the inaugural session of the Parliament and may - in narrowly defined cases dissolve the Parliament. Further the President may send an Act of Parliament to the Constitutional Court for review on its conformity with the FL. The President appoints among others the professional judges, the Ministers and also the President of the National Bank. [Article 9] The Government is the supreme organ of the executive. The head of the executive is the Prime Minister who is elected by the Parliament upon the nomination of the President of the Republic. [Articles 15 and 16]

The Constitutional Court (CC) is defined by the FL as "the supreme organ for the protection of the Fundamental law." [Article 24 (1)] The CC is composed of fifteen members elected by the Parliament with the majority of two-thirds of the votes of all Members of the Parliament and hold their office for twelve years. The competence of the $\mathrm{CC}$ includes among others the ex ante examination of unconstitutionality of Acts of Parliament adopted but not yet promulgated; the review of laws adopted and promulgated with regard their conformity with the $\mathrm{FL}$; on the basis of a constitutional complaint the review of laws to be applied in a specific case or of a judicial decision as to their conformity with the $\mathrm{FL}$; the examination of conflicts between domestic law and international treaties. [Article 24]

The FL gives a long list of human rights and proclaims that "the inviolable and inalienable human rights shall be respected" putting on the State the obligation to protect these rights." [Article 1 (1)]

\footnotetext{
1 The Fundamental Law of Hungary was adopted by Parliament on 18 April 2011 and entered into force on 1 January 2012.

2 Act no. XX of 1949. The 1989 and 1990 amendments repealed practically all provisions of the original "Stalinist Constitution".
} 
According to Article 1 (2) of the FL "Hungary shall recognize the fundamental human rights [...]." Any law that fails to respect the fundamental rights is to be struck down by the CC. Thus one may say that the CC is perhaps the most important guarantor of human rights. However, there is also the Commissioner for Fundamental Rights with the exclusive task of protecting human rights. The Commissioner "shall investigate those controversies related to fundamental rights that came to his or her attention, or have those controversies investigated, and initiate general or specific measures to redress them." [Article 30 (2)] Also the judiciary plays an important role in the protection of human rights. According to the $\mathrm{FL}$ "judges shall be independent and subject only to Acts of Parliament"; they "may not be instructed in relation to their judicial activities." [Article 26 (1)] However, the FL itself in a rather unconventional way instructs judges on how to interpret the law: when applying laws "courts shall interpret the law primarily in the light of their purpose and in accordance with the Fundamental Law. When interpreting the Fundamental Law or any other law, it shall be presumed that they are reasonable and serve the public good and morally right and economic purposes (emphasis KB)." [Article 28]

\subsection{Accession by Hungary to the European Convention on Human Rights and Fundamental Freedoms}

Hungary was the first "post-communist" country to join the Council of Europe and signed the European Convention on Human Rights and Fundamental Freedoms (ECHR or Convention) on 6 November 1990. Although there was some pressure on the Ministry of Justice to guarantee that Hungary be also the first new democracy to ratify the Convention it was decided to thoroughly scrutinize Hungarian legislation on its compatibility with Strasbourg case-law and to first prepare legislation in areas where compliance with the jurisprudence of the Convention organs called for modifications. Thus an Inter-Ministerial Committee was set up chaired by the then Ministry of Justice Deputy Secretary of State and composed of senior civil servants working in the various ministries. After 17 months of study and analysis the report was submitted to the government. The conclusions were published in a Hungarian human rights journal and were made available to all Members of Parliament. ${ }^{3}$ The Committee identified relatively few areas where the Convention required modification of Hungarian laws. This was partly explained by the fact that by the 1989 amendment of the Constitution the chapter on human rights was radically modified. Further Parliament enacted in the years of 1989 and 1990 numerous acts relating to basic rights, such as the right to strike, freedom of assembly, freedom of conscience. In addition amendments to the Code of Criminal Procedure and the Penal Code also contributed to narrowing the gap between Hungarian law and the Convention. Whereas earlier law authorized the prosecutor to order and prolong pretrial detention in the investigation phase the amendment put the decision in the hands of a judge. The chapter on political offenses in the Criminal Code was completely reformulated and the difference in the level of protection afforded for private and public property was eliminated.

In spite of the enormous progress in the protection of human rights through legislation in the years of 1989 and 1990 the Committee found that the absence of judicial review in a number of areas rendered Hungarian law incompatible with the Convention. Before the amendment of the relevant acts in 1994 Hungarian law precluded judicial review of detention for medical reasons in psychiatric hospitals, of detention as a disciplinary sanction of members of the armed forces or of disciplinary sanctions imposed on lawyers and medical doctors. The Committee took the position that the amendments of the relevant acts can be submitted to Parliament before ratification. At the same time it concluded that due to the need to enact a brand new law, which may take a couple of years, access to a court as required by Article 6 (1) of the Convention may not be guaranteed in

\footnotetext{
${ }^{3}$ For a detailed summary of the findings see Doc. $\mathrm{H}(95) 2$ of the Council of Europe published also in Andrew Drzemczewski, 'Ensuring Compatibility of Domestic Law with the European Convention on Human Rights Prior to Ratification: The Hungarian Model. Introduction to a Reference Document,' 16 Human Rights Law Journal (1995) no. 7-9, 241-260.
} 
proceedings for administrative offenses (regulatory offenses, Ordnungswidrigkeiten) prior to ratification. That is why the instrument of ratification contained a reservation in this respect. ${ }^{4}$

Most of the recommendations made by the Committee were accepted by Parliament and the relevant laws were amended accordingly though in December 1994 only. ${ }^{5}$

\subsection{The status of the ECHR in the domestic legal order}

Hungary's new Fundamental Law (FL) adopted on 18 April 2011 and which has been in effect since 1 January 2012 defines the relation between international and domestic law in the same way as the former Constitution. The FL first stipulates that "Hungary shall ensure the conformity between international law and Hungarian law in order to fulfill its obligation under international law". [Article $\mathrm{Q}$ (2)] Further, the FL proclaims that "Hungary shall accept the generally recognized rules of international law" and that "other sources of international law shall become part of the Hungarian legal system by promulgation". [Article Q (3)]

Generally recognized rules of international law become automatically part of the Hungarian legal order (and in the CC's interpretation are above domestic laws), while international treaties must be proclaimed in a domestic law. ${ }^{6}$

Thus the FL like the previous Constitution opted for the dualist approach: international treaties must be transformed in the form of an Act of Parliament or a decree to be part of the Hungarian legal system and by this to become directly enforceable. ${ }^{7}$ Since rules on fundamental rights and obligations may be laid down exclusively in an Act of Parliament international human rights treaties must also be promulgated in an Act enacted by Parliament.

From all this it may appear that the Convention promulgated by an Act of Parliament has the same rank as any other act and in case of conflict the lex posterior prevails.

However, in the Constitutional Court's interpretation the act transforming an international treaty is superior to other acts and in the case of conflict the latter have to be annulled. ${ }^{8}$ It should be noted that the Fourth Amendment to the FL repealed the rulings of the Constitutional Court given prior to the entry into force of the FL. ${ }^{9}$ This was interpreted to mean that the Court is no longer bound by its earlier rulings and may not even make reference to them. However the Constitutional Court made it clear that it still may make reference to arguments used in earlier decisions provided that it gives a detailed reasoning why it does so. However, the $\mathrm{CC}$ added that due to the Fourth Amendment to the FL it may disregard legal principles elaborated in earlier decisions even if the text of the given provision in the $\mathrm{FL}$ and the previous Constitution is identical. ${ }^{10}$ In principle the Constitutional Court is

\footnotetext{
4 The ratification instrument was deposited on 5 November 1992.

${ }^{5}$ Act no. XC of 1994 on the amendment of Law Decree no. 3 of 1984 on attorneys, Act no. XCII of 1994 on the amendment of the Code of Criminal Procedure. The acts amending the Criminal Code were enacted in December of 1994.

${ }^{6}$ Constitutional Court Decision no. 53/1993. (X. 13.).

7 The "generally recognized rules" are transformed directly by the Constitution (and similarly by the Fundamental Law). Constitutional Court Decision no. 53/1993. (X. 13.).

${ }^{8}$ Constitutional Court Decision no. 15/2004. (V. 14.), Decision no. 2/1994. (I. 14.), and Decision no. 99/2008. (VII. 3). For details see Petra Bárd, 'Hungary' in: Leonard Hammer and Frank Emmert (eds.), The European Convention on Human Rights and Fundamental Freedoms in Central and Eastern Europe (The Hague: Eleven Publishing, 2012), p. 225-226.

${ }^{9}$ Article 19 of the Fourth Amendment, incorporated as point 5 in the Closing and Miscellaneous Provisions of the Fundamental Law. This provision might have been the legislator's response to the Constitutional Court Decision no. 22/2012. (V. 11.), which explicitly declared that the Court in subsequent cases may use the arguments appearing in its decisions rendered prior to the entry into force of the Fundamental Law provided that the content of the provision in the Fundamental Law is identical or similar to that of the previous Constitution and if the rules of interpretation of the Fundamental Law permit the use of the arguments.
} 
therefore free to reconsider its position on the supremacy of acts promulgating international treaties over other Acts of Parliament in the future.

However, this is very unlikely since both the $\mathrm{FL}$ and the law on the Constitutional Court ${ }^{11}$ provide for the review of domestic laws on their compliance with international treaties and not the other way round. According to Article $24(2) f$ ) of the FL the Constitutional Court shall examine whether rules of law are in conflict with an international treaty. Article 24 (3) stipulates that the CC may "annul the law or its provision conflicting with an international treaty." Section 32 (1) of the law on the Constitutional Court provides that "(P)ursuant to Article $24(2) f$ ) of the Fundamental Law, the Constitutional Court shall examine legal regulations on request or ex officio in the course of any of its proceedings." In addition to listing those entitled to request such a review ${ }^{12}$ par. (2) of the same section provides that "judges shall suspend judicial proceedings and initiate Constitutional Court proceedings if, in the course of the adjudication of a concrete case, they are bound to apply a legal regulation that they perceive to be contrary to an international treaty." ${ }^{13}$

The relation between the $\mathrm{FL}$ and the Convention is not completely clear. Already the report of the Inter-Ministerial Committee raised the question of how an eventual conflict between the Constitution and the Convention should be resolved. It observed that in principle such a conflict may not be ruled out. First, because not all Convention rights are guaranteed by the Constitution, and second because the Constitutional Court and the European Court of Human Rights (ECtHR) may come to different conclusions when interpreting the content of the very same right. The Committee's proposal was to grant the Convention constitutional status ${ }^{14}$ but the recommendation was not accepted by the legislator. From a ruling of the CC dating back in 1993 one could eventually infer that the Convention as part of international law is above the country's basic law. Article $Q$ (2) of the FL provides that " $(I) n$ order to comply with its obligations under international law, Hungary shall ensure that Hungarian law is in conformity with international law". The text follows the interpretation given by the CC of Article 7 (1) of the 1949 Constitution which stipulated that Hungary shall ensure that domestic law is in conformity with the country's obligations assumed under international law. According to the $\mathrm{CC}$ the duty to ensure conformity extends to the entire domestic legal system, the Constitution included..$^{15}$ From this one may deduce the supremacy of international law since Hungary - in case of conflict - can modify unilaterally only its domestic law, the Constitution included, in order to ensure conformity with international law. However, one could argue that in order to ensure harmony with domestic law international treaties may be renegotiated or should this be not feasible the conflict between domestic law and the international obligation can be abandoned by the country relieving itself of the obligation by denouncing the treaty in question.

Those who are in favor of the supremacy of the Convention as an international treaty might be tempted to invoke the argumentation of the European Court of Justice in support of their claim. According to ECJ jurisprudence EU law is superior to national laws and EU law is supreme even over

\footnotetext{
${ }^{10}$ Constitutional Court Decision no. 13/2003. (VI. 17.), par. 30-31.

${ }^{11}$ Act no. CLI of 2011 on the Constitutional Court.

12 One quarter of Members of Parliament, the Government, the President of the Curia, the Prosecutor General and the Commissioner for Fundamental Rights.

13 Judges' authorization to initiate proceedings before the Constitutional Court constitutes a laudable development. Under the former law on the Constitutional Court (Act no. XXXII of 1989) this could only be done by the President of the Supreme Court and the Chief Public Prosecutor. The Inter-ministerial Committee preparing the ratification in its report in 1992 suggested that each court should be given the right to suspend the proceedings and invoke the Constitutional Court in case of a perceived conflict between domestic legislation and the Convention. See Andrew Drzemczewski, 'Ensuring Compatibility of Domestic Law with the European Convention on Human Rights Prior to Ratification: The Hungarian Model. Introduction to a Reference Document,' 16 Human Rights Law Journal (1995) no. 7-9, 250.

14 Ibid 249-250.

${ }^{15}$ Constitutional Court Decision no. 53/1993. (X. 13.).
} 
provisions of national Constitutions. ${ }^{16}$ At the same time the EU in exercising its powers must respect international law. Measures adopted must be interpreted, and their scope limited, in the light of the relevant rules of international law. ${ }^{17}$ International law is part of the European Union legal order and is binding on the institutions. ${ }^{18}$ In other words international law is above EU law. Thus international law appears to be superior over national Constitutions. The problem with this argumentation is that the supremacy doctrine has not been extended to the area of human rights. According to Article 51 of the Charter of Fundamental Rights the provisions of the Charter are addressed to the EU institutions and to Member States only when they are implementing EU law. Thus Member States shall respect the rights enshrined in the Charter "in accordance with their respective powers."19

\subsection{Potential conflicts between Hungary's Fundamental Law and the}

\section{Convention}

In sum the relationship between the basic law of Hungary and the Convention is not completely clear and there is no guidance on how a potential conflict should be resolved. Unfortunately such a conflict between the new Fundamental Law and the Strasbourg jurisprudence may not be ruled out. The Venice Commission (VC) in its report on the Fourth Amendment to the $\mathrm{FL}^{20}$ identified those provisions which fail to comply with European standards set among others in the judgments of the ECtHR. Thus the VC when assessing the concept of family as set forth in the Amendment recommended that "the FL should not exclude other guarantees of family and family life" and pointed out that the ECtHR "has gradually broadened the scope of Article 8 of the ECHR on the right to family life". ${ }^{21}$

Article $L$ of the Fundamental Law as amended stipulates that "Hungary shall protect the institution of marriage as the union of a man and woman established by voluntary decisions and the family as the basis of the nation's survival. Family ties shall be based on marriage and the relationship between parents and children."

It should be noted that prior to the adoption of the Fourth Amendment the Constitutional Court struck down the provision on the definition of family in the Family Protection Act. ${ }^{22}$ Section 7 of the Act defined the family as "the relationship between natural persons in an economic and emotional community that is based on a marriage between a woman and a man, or lineal descent." The Commissioner for Fundamental Rights challenged the constitutionality of the narrow definition of the family. With reference to numerous ECtHR judgments he also claimed that Section 7 of the Family Protection Act is contrary to the right to respect for private and family life guaranteed by Article 8 of the Convention. ${ }^{23}$ The Constitutional Court struck down Section 7 of the Family Protection $\mathrm{Act}^{24}$ and found that it was therefore unnecessary to extend the examination to its

\footnotetext{
${ }^{16}$ Constitutions of the Member States cannot prejudice the primacy of Community law. See especially Case 11/70, Internationale Handelsgesellschaft $\mathrm{mbH}$ v. Einfuhr-und Vorratsstelle für Getreide und Futtermittel, 1970 E.C.R. 1125, par. 3, and Case 314/85, Foto-Frost v. Hauptzollamt Lübeck-Ost, 1987 E.C.R. 4199, par. 11-16.

17 Joined Cases 402/05, Yassin Abdullah Kadi and Al Barkaat International Foundation, 2008 E.C.R. 6351, par. 291

${ }^{18}$ Case 364/10 Hungary v. Slovak Republic, Judgment of the Court (Grand Chamber) of 16 October 2012 par. 44.

${ }^{19}$ Charter of Fundamental Rights of the European Union, 200/C 303/01, Article 51.

20 European Commission for Democracy through Law (Venice Commission), Opinion 720/2013, CDLAD(2013)012, Strasbourg, 17 June 2013 (Opinion).

21 Ibid, par. 20

${ }^{22}$ Act no. CCXI of 2011 on the protection of families.

${ }^{23}$ X., Y. and Z. v. United Kingdom [GC] 21830/93 (22/04/1997), Reports of Judgments and Decisions 1997-II, par. 36;. Schalk and Kopf v. Austria 30141/04 (24/06/2010), Reports of Judgments and Decisions 2012, par. 94; Kozak v. Poland 13102/02 (02/03/2010), par. 98; K. and T. v. Finland [GC] 25702/94 (12/07/2001), Reports of Judgments and Decisions 2001-VII, par. 150.
} 
compatibility with the ECtHR. However, the Constitutional Court acting beyond the confines of the petition has extensively reviewed Strasbourg case law on Article 8 and $14^{25}$ and it drew - partly on the basis of ECtHR jurisprudence - the conclusion that also Section 8 of the Family Protection Act excluding non-married couples and same-sex registered partners from intestate inheritance was in breach of the FL. ${ }^{26}$ As a reply to the Constitutional Court ruling the narrow definition of family was transferred to the $\mathrm{FL}$ itself. ${ }^{27}$

Another potential source of conflict between the FL and the Convention created through the Fourth Amendment is the process of the recognizing churches. Article VII of the FL as amended stipulates among others that certain organizations engaged in religious activities may be recognized as churches by Parliament through a cardinal law. The cardinal law may prescribe as a requirement for recognition an extended period of operation, social support and suitability to promote community goals.

The Venice Commission expressed its concern as to the fact that the decision is in the hands of Parliament and therefore recognition or denial will be based more or less on political considerations. It also noted that the absence of transparency of the decision making process, the lack of giving reasons for the decision does not comply with standards of due process of law. ${ }^{28}$ Invoking the jurisprudence of the ECtHR the Commission also noted that Article 9 of the Convention in conjunction with Article 14 (prohibition of discrimination) "obliges the State to remain neutral and impartial in exercising its regulatory power in the sphere of religious freedom." ${ }^{29}$ In the Commission's view the absence of a remedy on substance in case of refusal may result in a breach of the right to an effective remedy guaranteed by Article 13 of the Convention. ${ }^{30}$

The Commission rightly criticized the provision in the Fourth Amendment that had added a paragraph 5 to Article IX of the FL and which could easily be abused for oppressing political criticism. The new provision prohibits the exercise of the right to freedom of speech "with the aim of violating the dignity of the Hungarian nation or of any national, ethnic, racial or religious community." Prohibiting speech aimed at violating "the dignity of the Hungarian nation" might be applied "to curtail criticism of the Hungarian institutions and office holders which could be incompatible" ${ }^{31}$ with ECtHR jurisprudence on freedom of expression (Article 10).

As pointed out earlier the relationship between the Fundamental Law and the Convention is unclear. However, the lack of clarity is of little practical significance. Most provisions of the FL become operative through "ordinary" implementing legislation. True, in order to prevent the Constitutional Court from finding certain legal norms to be contrary to the $\mathrm{FL}$ those rules were incorporated into the FL. ${ }^{32}$ Similarly certain provisions found already to be incompatible with the FL by the

\footnotetext{
24 Constitutional Court Decision no. 43/2012. (XII. 20.). The Court found that the provision was contrary to Article $L$ of the $F L$ which at that time - in addition to defining marriage - simply proclaimed that the family was the basis of the nation's survival without providing a definition of that.

25 Ibid, par. 66-72.

${ }^{26}$ This, too, was challenged by the Commissioner for Fundamental Rights. The Constitutional Court's primary concern with the inheritance provision was that due to its conflict with other laws it violated the principle of legal certainty, an important aspect of the rule of law.

27 In fact the FL further narrowed the definition of family as compared to that in the Family Protection Act. For a critical assessment of the amendment of Article $L$ see Tamás Dombos - Eszter Polgári, The definition of family (Article 1 of the Fourth Amendment). Available at:

http://www.fundamentum.hu/sites/default/files/amicus_brief_on_the_fourth_amendment4.pdf.

28 Par. 32. of the Opinion

${ }^{29}$ Religionsgemeinschaft der Zeugen Jehovas v. Austria 40825/98 (31/07/2008), par. 97. (quoted in par. 34. of the Opinion).

30 Par. 36. of the Opinion.

31 Par. 53 of the Opinion. The Venice Commission refers to the ECtHR judgment in Altug Taner Akçam v. Turkey $27520(25 / 11 / 2011)$.
} 
Constitutional Court were transferred to the $\mathrm{FL}^{33}$ Therefore the $\mathrm{FL}$ contains numerous detailed provisions, which should be regulated on the level of ordinary law. ${ }^{34}$ However, even these detailed provisions may not be applied directly but need implementing legislation.

As concerns the human rights listed in the FL their scope and limits have definitely to be specified in separate acts. As indicated earlier treaties guaranteeing fundamental rights have to be promulgated in the form of an Act of Parliament and according to the Constitutional Court's ruling the promulgating act is superior to any other act. Therefore in case of conflict between the act transforming an international treaty and another act it is the former that prevails and the latter that has to be annulled.

\section{Mechanisms of implementation}

\subsection{Legislation to bring Hungarian law in line with the court's jurisprudence}

If the source of a Strasbourg judgment condemning Hungary is a piece of legislation that cannot be applied in line with the Convention, the necessary amendments to the law are made relatively rapidly. Thus following the Csüllög judgment ${ }^{35}$ which in the year 2011 found Hungary in violation of Article 3 and Article 13 in conjunction with Article 3 due to the cumulative effects of the stringent prison regime to which the applicant was subjected and the absence of any effective means to challenge the prison authorities' decision, the law on the penitentiary system was amended in the same year. ${ }^{36}$ In the Ternovszky case ${ }^{37}$ the Court found that the absence of comprehensive legislation on medical doctors and health professionals who assist home birth and the fact that they are thus exposed to a potential conviction for regulatory offense has limited the choices of the applicant considering home delivery and violated her right to private life. A few months after the judgment a Government decree on the rules and conditions of giving birth outside a medical institution was adopted. ${ }^{38}$

However, following the Fratanolo judgment ${ }^{39}$ which found that the criminal conviction for the use of the red star amounted to the violation of the applicant's freedom of expression ${ }^{40}$ the Hungarian Parliament explicitly proclaimed its unwillingness to amend the Criminal Code. Resolution 58/2012(VII.10) pointed out that "the provision of the Criminal Code prohibiting the use of symbols of totalitarian regimes was adopted for the protection of the democratic social order, with a view to the country's historical past, in line with principles which guarantee respect for human dignity and in compliance with the constitutional order. Therefore, Parliament disagrees with the judgment appl.

\footnotetext{
32 See for instance Article IV (2) permitting the imposition of life imprisonment without parole or the detailed rules on the reopening of the prosecution of crimes committed during the Communist regime after the expiration of the prescription period. [Article U (6)-(8) subsequent to the Fourth Amendment].

33 See for instance Article VII (2) and (4) on the recognition of churches following the Fourth Amendment. Also the previous Constitution was amended several times following rulings of the Constitutional Court finding a piece of legislation to be contrary to the Constitution. For details see par. 83 of the Opinion of the Venice Commission.

${ }^{34}$ Also the Venice Commission criticizing Article U (6)-(8) of the FL on the prolongation of the statute of limitation for crimes not prosecuted under the Communist regime observes that individual criminal responsibility and limitation periods "should be regulated in the penal code or other ordinary law, rather than directly by the Constitution. Par. 29. of the Opinion.

${ }^{35}$ Csüllög v. Hungary 30042/08 (07/06/2011).

${ }^{36}$ Act no. CL of 2011 on the amendment of certain laws on criminal justice.

${ }^{37}$ Ternovszky v Hungary 67545/09 (14/12/2010).

38 Government Decree no 35/2011 (III.21.).

39 Fratanoló v Hungary 29459/10 (03/11/2011).

40 This was the second time that the ECtHR found the criminal conviction of a politician for wearing the red star to be contrary to the Convention. The first case was Vajnai v. Hungary 33629/06 (08/06/2008).
} 
no. 29459/10 finding Hungary in violation of the Convention, the opinion of the ECtHR and with the amendment of the Criminal Code." The Resolution also stated that the amount of compensation Hungary will have to pay in the future due to the application of the Criminal Code's relevant provision should be paid from the parties' budget. By this Parliament sent out the message that it is prepared to take upon itself the financial obligation deriving from its insistence on upholding the criminal prohibition of the use of symbols of totalitarian regimes as it stands.

In the laconic reasoning the Parliament made reference to the Constitutional Court Decision no. $14 / 2000$ (V. 12.) which found the relevant provision of the Criminal Code to be in compliance with the Constitution. Therefore "[preserving the Criminal Code unamended] within the legal system and its application in individual cases is compatible with the democratic principles. Also the country's historical past justify upholding the provision." Without elaborating on the Resolution ${ }^{41}$ I would like to make two comments. First, the Vajnai and Fratanoló judgments do not suggest that the only way to guarantee compliance with the Convention is through the amendment of the Criminal Code. The judgments give clear instructions on how the provision prohibiting the use of symbols of totalitarian regimes can be applied without infringing the Convention. Second, invoking the Constitutional Court's decision rendered in the year 2000 as a justification for not amending the relevant provision of the Criminal Code is clearly mistaken since the $\mathrm{CC}$ ruled on the matter prior to the Vajnai and Fratanoló judgments. Indeed the CC in 2013 reviewed its position and found that the criminal offense of using symbols of totalitarian regimes as formulated in the Criminal Code violates the constitutional principle of legal certainty and freedom of expression. ${ }^{42}$

As indicated earlier a comprehensive review of the Court's jurisprudence was undertaken prior to the ratification of the ECHR and as a result Hungarian law was brought in line with Strasburg caselaw. At present there is no unit within the Government with the mandate to permanently follow the Court's jurisprudence and signal if in the light of a judgment "condemning" a country other than Hungary also Hungarian law has to be amended. The staff of the department within the Ministry of Public Administration and Justice ${ }^{43}$ who represent the government as agents before the Court occasionally draw the attention of the competent department to consider the amendment of a given law if they come across a judgment that might be relevant for Hungary as well. However, there is no explicit obligation to follow the case-law and signal the need for legislation. From time to time the Hungarian Council of Europe Mission in Strasbourg contacts the Department if they consider a judgment rendered in respect of another State Party to be of relevance for Hungary. Thus "Strasbourg proofing" is incidental and not systematic. It should be noted that only three civil servants work in the Office of the Agent before ECHR who not only represent the government before the Court but are also responsible for coordinating the execution of judgments. Thus they hardly have the capacity to follow the case-law regularly and review Hungarian legislation on its compliance with Strasbourg jurisprudence. The failure to regularly follow the jurisprudence of the ECtHR and the absence of "proactive harmonization" increases the likeliness that Hungary will be found in breach of the Convention. The condemnation for the breach of the equality of arms principle in Art. 5 (4) procedure in $2013^{44}$ for instance could have been avoided had the Hungarian legislator drawn the lesson from the Garcia Alva judgment of the ECtHR dating back to $2001 .{ }^{45}$

\footnotetext{
${ }^{41}$ For a detailed and in depth analysis of the legal, moral and political implications of the non-enforcement of the Fratanoló judgment see: Petra Bárd, 'The non-enforcement of Strasbourg decisions and its consequences' in: Jürgen Busch, Konrad Lachmayer et al. (eds.), International Constitutional Law in Legal Education. Proceedings of the Erasmus IP NICLAS 2007-2012, International and Comparative Public Law Series (Schriften zum Internationalen und Vergleichenden Öffentlichen Recht) (Vienna: Nomos, 2013), forthcoming, p. 8.

42 Constitutional Court Decision no. 4/2013(II. 21.) According to the new Penal Code (Act no. C of 2012) that entered into force on 1 July 2013 the display of symbols of totalitarian regimes is punishable only if done in a manner that is suitable for disturbing public peace (Section 335).

${ }^{43}$ Department of International Criminal Law and the Office of the Agent before ECHR.

${ }^{44}$ X.Y. v. Hungary 43888/08 (19/03/2013).

45 Garcia Alva v. Germany 23541/94 (13/02/2001).
} 
If a draft law ${ }^{46}$ by its nature obviously interferes with fundamental rights as it is the case with the Criminal Code or the Code of Criminal Procedure, the draft is submitted to the Office of the Agent for review on its compliance with Strasbourg case law. However where the human rights implications of a draft law are less evident it depends on the competence of the civil servants working on the draft if the Office of the Agent receives the draft or not. Unfortunately some of the draft laws of financial nature are as a rule not submitted to the Office although they might run counter to Strasbourg standards. Over the last two years several important bills have been submitted by individual Members of Parliament and not by the Government. In these cases the Office of the Agent is prevented from reviewing the bill on its compliance with Strasbourg jurisprudence. The absence of review resulted in finding Hungary in breach of the right to the peaceful enjoyment one's possessions (Article 1 of Protocol No. 1) in a number of cases where the applicants complained of the withdrawal of their severance payments based on an Act adopted upon the initiative of individual Members of Parliament. ${ }^{47}$

It has to be noted, that irrespective of who is the initiator the bill ${ }^{48}$ it has to be reviewed by the competent Parliamentary Committees. Thus the Parliamentary Committee on Human Rights, Minorities, Civic and Religious Affairs or the Constitutional, Judicial and Standing Orders Committee may in principle signal their human rights concerns and propose amendments to the bill accordingly. ${ }^{49}$

\subsection{Execution of judgments}

The Office of the Agent before ECHR in the Ministry of Public Administration of Justice is responsible for the execution of the Court's judgments. The Office is in charge of reporting to the Committee of Ministers (CM) on the payment of the sum awarded by the Court as just satisfaction or set in a friendly settlement. The Office is responsible to inform the $\mathrm{CM}$ on the individual measures taken to remedy the violation.

In case general measures are required due to structural deficiencies in order to prevent future breaches of the Convention the Office after consulting the competent authorities prepares an action plan and submits it to the $\mathrm{CM}$. Currently four areas are identified where multiple violations are to be expected unless structural problems are solved. First, the length of proceedings must be shortened and an effective remedy in case of unreasonable delay must be introduced. In the overwhelming majority of the cases that are brought before the ECtHR it is the unreasonable length of civil proceedings that is complained of by the applicants. On 31 December 2012 out of the 89 pending cases 50 concerned the length of proceedings and out of the 1046526351 Hungarian Forint 813 630760 Hungarian Forint was paid for compensation in the year 2012 because of unreasonable delays in proceedings. ${ }^{50}$

The second structural deficiency identified by the $\mathrm{CM}$ has its source in the provision of the Criminal Code that penalizes the public display of symbols of totalitarian regimes, the red star among them and the way courts apply the relevant provision. It was already in 2008 that in the Vajnai case ${ }^{51}$ the ECtHR found the conviction of the applicant for the use of totalitarian symbols to be in violation of Article 10 of the Convention. In 2010 the Court again in a case the facts of which were practically

\footnotetext{
${ }^{46} \mathrm{~A}$ draft law is a legal text discussed and commented by the competent Ministries, interest groups, civil society prior to its submission to Parliament. The text submitted to the National Assembly it is termed a "bill".

${ }^{47}$ For example: R. Sz. v. Hungary 41838/11 (02/07/2013); Gáll v. Hungary 49570/11 (25/06/2013); and N.K.M. v. Hungary 66529/11 (14/05/2013).

${ }^{48}$ According to Article 6 (1) of the FL a draft law can be submitted by the President of the Republic, the Government, a Parliamentary Committee or any Member of Parliament.

${ }^{49}$ For a detailed description of the legislative process visit Parliament's website http://parlament.hu/angol/legislation.htm.

50 Information provided by the Office of the Agent before the ECtHR.

51 Vajnai v. Hungary 33629/06 (08/07/2008).
} 
identical with those in Vajnai found that the criminal conviction was a disproportionate interference with the applicant's freedom of expression. ${ }^{52}$ For the time being several applications are pending before the Court alleging that the conviction for the public display of the red star was in violation of the Convention. ${ }^{53}$ The execution of the Court's judgment requires legislative action or change in judicial practice.

A further area of concern calling for structural changes is overcrowding in Hungarian prisons. The penitentiary system fails to comply with the requirement set by the European Committee for the Prevention of Torture and Inhuman or Degrading Treatment or Punishment ("the CPT") to guarantee at least four square meters for each inmate resulting in a series of ECtHR judgments finding Hungary in breach of freedom from inhumane treatment. ${ }^{54}$ Finally long term measures, such as education, training, effective investigation, must be taken to reduce police violence. ${ }^{55}$

\subsection{Ensuring compliance of court judgments with ECtHR jurisprudence}

All judgments that concern Hungary are published in Hungarian on the website of the Ministry for Public Administration and Justice. ${ }^{56}$ The summary of numerous important judgments of the ECtHR that concern other countries are published in Hungarian on the website of the Curia. ${ }^{57}$ However, the majority of the judgments date back to the 1980s and 1990s. (It is worth of being noted that also the last Recommendation of the Committee of Ministers available on the Curia's website in Hungarian is the 2004 Recommendation on the improvement of domestic remedies, ${ }^{58}$ whereas since then a number of important Recommendations affecting the judiciary and the administration of justice have been adopted such as the Recommendation on effective remedies for the excessive length of proceedings ${ }^{59}$ or the Recommendation on judges. ${ }^{60}$ )

Furthermore, the Curia's Office for International Relations and European Law publishes a monthly newsletter in Hungarian also available on the website of the Curia ${ }^{61}$ which - on the basis of the press releases issued by the Court - gives summaries of the most important judgments rendered by the ECtHR in the previous month.

Information in Hungarian on the overall jurisprudence of the ECtHR is available in manuals and commentaries. It was in 1999 that Vincent Berger's "Case-Law of the European Court of Human Rights" 62 summarizing the most important judgments of the ECtHR was published in Hungarian. This was followed by several editions of a manual on Strasbourg jurisprudence written by András Grád. ${ }^{63}$

\footnotetext{
52 Fratanoló v. Hungary 29459/10 (03/11/2011).

53 See the communicated cases of Krisztina Noé, Attila Vajnai and András Attila Bakó v. Hungary 24515/09; 24539/09; and 24611/09.

54 Szél v. Hungary 30221/06 (07/07/2011); Fehér v. Hungary 69095/10 (02/07/2013).

55 See for example: Réti and Fizli v. Hungary 31373/11 125/09/2012); Gubacsi v. Hungary 44686/07 (28/06/2011) or Barta v. Hungary 26137/04 (10/04/2007).

${ }^{56}$ Available at: http://igazsagugyiinformaciok.kormany.hu/az-emberi-jogok-europai-birosaganak-iteletei.

${ }^{57}$ Curia is the former Supreme Court. Available at: http://www.lb.hu/hu/nemzetkozi-kapcsolatok-esembjog?tid=96\&tid 1=102\&tid 2=All\&tid 3=All\&tid 4=All\&title=\&body value=\&page=2.

${ }^{58} \operatorname{Rec}$ (2004) 6 (adopted by the Committee of Ministers on 12 May 2004).

${ }^{59} \operatorname{Rec}(2010) 3$ (adopted by the Committee of Ministers on 24 February 2010).

${ }^{60} \operatorname{Rec}(2010) 12 \mathrm{E}$ Recommendation of the Committee of Ministers to member states on judges: independence, efficiency and responsibilities ( adopted by the Committee of Ministers on 17 November 2010).

${ }^{61}$ Available at: http://www.lb.hu/hu/hirlevel.

62 Volume I: 1960-1987 (Dublin: The Round Hall Press, 1989); Volume II: 1988-1990 (Dublin: The Round Hall Press, 1992).

63 The fourth edition of the manual with Mónika Weller as co-author was published in 2011. Grád Andás, Weller Mónika, A strasbourgi emberi jogi bíráskodás kézikönyve [Handbook on the Human Rights Jurisprudence of the Strasbourg Court] (Budapest: HVG-ORAC, 2011). For further publications on Strasbourg jurisprudence in selected areas see Petra Bárd,'Hungary', in: Leonard Hammer, Frank Emmert (eds), The
} 
Some of the judges of the Curia are appointed by the President of the Curia as advisors on European law to assist - in collaboration with the Office for International Relations and European Law - their colleagues at all levels of the court system in the interpretation of the ECtHR judgments. ${ }^{64}$ This is all the more important since - in principle - Hungarian judges are under the obligation to directly apply the Convention and the Strasbourg judgments. According to the law on the procedure concerning international treaties ${ }^{65}$ "in interpreting an international treaty the decisions of the body entrusted with the authority to settle disputes arising out of the treaty must also be considered" [Section 13(1)]. This provision was meant to put an end to the debate on the extent to which Strasbourg jurisprudence has to be followed in domestic proceedings. ${ }^{66}$ Prior to the entering into force of the law on international treaties only the Constitutional Court's duty to observe Strasbourg jurisprudence was obvious due to the constitutional provision that Hungary shall ensure the conformity between international and Hungarian law in order to fulfill its obligation under international law [Article Q (2)]. Although the Supreme Court in its judgments dating back to 2003 and 2004 stated that all Hungarian courts have to follow the jurisprudence of the ECtHR, this position was not shared by all judges: some insisted on applying exclusively domestic laws and opined that that the ECtHR judgments were not binding for Hungarian courts. ${ }^{67}$ Unfortunately even after the entering into force of Act $L$ of 2005 on the procedure concerning international treaties there have been cases where courts consciously disregarded judgments of the ECtHR arguing that those are binding on the Government as party to the Strasbourg proceedings only. As the Metropolitan Court of Appeal argued in a case: although ECtHR "judgments - as a result of legal harmonization - shape Hungarian law, [...] Hungarian courts are not obliged or authorized to apply them directly" ${ }^{68}$ Also in the mentioned Fratanoló case ${ }^{69}$ which resulted in finding Hungary in breach of the Convention for the applicant's conviction for using the red star in public, the Pécs Court of Appeal argued that it may not apply the test developed by the ECtHR in the Vajnai judgment. In the court's opinion it has to apply the provision of the Hungarian Criminal Code according to which the offense is completed by the mere public display of symbols of totalitarian regimes. Therefore the court is prevented from extending the inquiry to further facts as indicated in the Vajnai judgment. ${ }^{70}$

Fortunately more and more courts in Hungary invoke Strasbourg jurisprudence in different type of cases, such as custody of children, pre-trial detention, judges' disqualification for lack of impartiality, or in personality rights law suits. ${ }^{71}$ However, as concerns the latter group all ECtHR judgments cited by the Hungarian courts are those which "appear in the relevant Constitutional Court decisions."72 It

European Convention on Human Rights and Fundamental Freedoms in Central and Eastern Europe (The Hague: Eleven International Publishing, 2012) p.229.

${ }^{64}$ Section 23(2) of Instruction 9/2012 of the President of the Curia on the Organizational and Operational Regulation of the Curia. Available at http://www.kuria-birosag.hu/sites/default/files/szabalyzatok/szmsz 1.pdf 65 Act no. L of 2005.

${ }^{66}$ Eszter Polgári, 'The European Convention on Human Rights and the Case-Law of the European Court of Human Rights in Hungarian Judicial Practice', Fundamentum (2008), no. 5, 74.

67 Ibid, pp. 74, 75, 80.

68 Judgment no. Pfv.V.20.607/2007/9. Cited in Ibid, p. 75.

69 Fratanoló v. Hungary 29459/10 (03/11/2011).

${ }^{70}$ According to the Vajnai judgment the criminal conviction for using the red star is in line with the Convention if it can be proven that there was a real danger of restoring Communism and that the defendant identified herself/himself with the meaning of the sign representing a totalitarian regime. For a critical assessment of the position of the Pécs Court of Appeal. Petra Bárd, 'The non-enforcement of Strasbourg decisions and its consequences' in: Jürgen Busch, Konrad Lachmayer et al. (eds.), International Constitutional Law in Legal Education. Proceedings of the Erasmus IP NICLAS 2007-2012, International and Comparative Public Law Series (Schriften zum Internationalen und Vergleichenden Öffentlichen Recht) (Vienna: Nomos, 2013), forthcoming.

${ }^{71}$ For references to ECtHR case-law see Eszter Polgári, 'The European Convention on Human Rights and the Case-Law of the European Court of Human Rights in Hungarian Judicial Practice', Fundamentum (2008), no. 5, 74-80.

72 Ibid, p.77. 
must also be noted that when reading the references to Strasbourg jurisprudence in some of the decisions of higher courts and of the CC one may gain the impression that ECtHR case-law is invoked rather to give additional legitimacy to the conclusion the courts have already arrived at under Hungarian law.

From time to time in order to justify the desired outcome courts invoke Strasbourg jurisprudence when this is clearly inappropriate, or arbitrarily select certain passages of ECtHR decisions which are in complete contrast to the spirit of the judgment at hand. The CC for instance in the decision finding the provision of the Criminal Code that penalizes the violation of national symbols to be compatible with the Constitution ${ }^{73}$ invoked the Otto-Preminger Institute ${ }^{74}$ and Wingrove ${ }^{75}$ judgments. It rightly noted that in those cases the interference with the applicants' freedom of expression was found to be justified for the protection of others' right to respect for religious feelings but drew the arbitrary conclusion that the conviction and feeling of belonging to a given state should be afforded similar protection. The CC disregarded the fact that the ECtHR found the interference acceptable through reading Article 9 and 10 of the Convention together, while the "feeling of belonging to a certain state" may not be brought under any right listed in the ECHR. ${ }^{76}$

The decision of the Metropolitan Court on the prolongation of the pretrial detention in the case underlying the Hagyó judgment of the ECtHR ${ }^{77}$ is a striking example of the abusive reference to Strasbourg jurisprudence. ${ }^{78}$ According to the decision "there is extremely pressing public interest in fully and accurately exploring the criminal conduct that caused loss of state property of a magnitude unprecedented in the history of the Republic of Hungary and in convicting all members of the criminal organization suspected of having committed the crimes. The unimpeded conduct of the investigation requires that the suspects are completely deprived of their personal liberty. The authorities' activity aiming at proving the suspects' guilt must be given preference over the rights of the suspects. The suspects' right to liberty is outweighed by the public interest in prolonging the pretrial detention." The Metropolitan Court in brackets noted without indicating one single judgment that this is the position of the ECtHR. ${ }^{79}$

Fortunately the majority of judges correctly use Strasbourg jurisprudence when interpreting Hungarian law. This is partly due to the numerous trainings and workshops organized by the Hungarian Academy of Justice. In the period between 2008 and 2012 the Academy organized seminars and training courses targeting judges and prosecutors on ECtHR jurisprudence on among others expulsion, family life, the right to a fair trial in civil proceedings, pre-trial detention, detention of aliens, segregation, sexual violence, and guardianship. In addition to Hungarian judges and academics also foreign experts and representatives of human rights NGOs (Hungarian Helsinki Committee, Mental Disability Advocacy Center, European Roma Rights Center) were invited to give lectures or lead workshops. ${ }^{80}$

\footnotetext{
${ }^{73}$ Constitutional Court Decision no. 13/2000. (V. 12.).

${ }^{74}$ Otto-Preminger Institute v. Austria 13470/87 (20/09/1994), A295-A.

${ }^{75}$ Wingrove v. United Kingdom 17419/90 (25/11/), Reports of Judgments and Decisions 1996-V.

76 Judge Németh in his concurring opinion noted that the reference to the ECtHR judgments and the conclusion drawn was incorrect.

77 Hagyó v. Hungary 52624/10 (23/04/2013). The Court found Hungary in violation of Articles 3, 5(3), 5(4), 8, and Article 13 in conjunction with Article 8.

${ }^{78}$ Case no. 30. Bnf. 1355/2010.

79 The full text of the decision is available at http://hagyomiklos.com/files/07.pdf. I am grateful to Mr. András Kádár, co-president of the Hungarian Helsinki Committee for drawing my attention to the decision of the Budapest Court.

80 See for instance the program of the two days training session "Building bridges: Human rights in judicial practice and communication with the involvement of civil organizations" (28001/2008 OIT Hiv.).
} 


\section{The influence of the Strasbourg case-law in the democratization process and political pluralism - selected issues}

Undoubtedly the Strasbourg jurisprudence has had an impact on enhancing the democratic process and political pluralism. The Alajos Kiss judgment ${ }^{81}$ is of paramount importance as regards the right to free elections. The source of finding Hungary in breach of Article 3 of Protocol No. 1 was Section 14 of the Civil Code in conjunction with Article 70 (5) of the Constitution. Under the former provision a partial guardianship order enables the court to limit the legal capacity of persons with "diminished faculties". By virtue of Article 70 (5) of the Hungarian Constitution, such an order also entails the automatic loss of the right to vote. The applicant was therefore prevented from voting in the parliamentary elections in 2006. The ECtHR found that while the measure of disenfranchisement pursued a legitimate aim, the indiscriminate removal of voting rights without an individualized judicial assessment is incompatible with the Convention.

The ECtHR judgment might have reminded Hungarian law-makers that in the light of the Hirst judgment ${ }^{82}$ also the disenfranchisement of persons sentenced to imprisonment requires individualized assessment. According to the relevant provision of the Criminal Code in force until 1 July 2013 (section 41(3) of Act IV of 1978) during the execution of imprisonment convicts were prevented - among others - from taking part in elections.

The Fundamental Law brought Hungarian legislation in line with both the Alajos Kiss and the Hirst judgment. Article XXIII (6) stipulates that "a person disenfranchised by a court for committing an offense or due to his/her mental capacity shall have no suffrage." Thus persons with mental problems and individuals sentenced to imprisonment may be deprived of their right to take part in elections only by a specific court ruling preceded by an individualized assessment.

Also the judgments of the ECtHR finding Hungary in breach of Article 11 strengthened political pluralism. In Bukta and Others v. Hungary ${ }^{83}$ the Court found that the dispersal of a spontaneous peaceful assembly because of the demonstrators' failure to notify the police in advance was in breach of Article 11. Following the Bukta judgment the Constitutional Court ruled that freedom of assembly extends also to demonstrations held without prior organization and annulled the provision of the law on freedom of assembly (Act no. III of 1989) which listed the absence of prior notification among the grounds for dispersing demonstrations. ${ }^{84}$

In Patyi and Others v. Hungary 85 the ECtHR found that the interference with the applicants' freedom of assembly had been disproportionate. The applicants who were among the creditors of an insolvent private company were planning to hold silent demonstrations in front of the Prime Minister's private home. They duly notified the police, which refused to grant permission with the explanation that the demonstration would hinder traffic. The decision of the police was confirmed by the Budapest Regional Court. Although the interference pursued the legitimate aims of protecting others' rights and the prevention of disorder the ECtHR found the explanation given by the police and the court unconvincing and concluded that the limitation of the applicants' freedom of assembly was not necessary in a democratic society.

The above judgments of the ECtHR have broadened the scope of freedom of expression and contributed significantly to the strengthening of political pluralism primarily via rulings of the Constitutional Court. In 1994 the CC found in its decision focusing on freedom of the press ${ }^{86}$ that the

\footnotetext{
${ }^{81}$ Alajos Kiss v. Hungary 38832/06 (20/05/2010).

82 Hirst v. the United Kingdom [GC] 74025/01 (06/10/2003), Reports of Judgments and Decisions 2005-IX. See also Greens and M.T. v. the United Kingdom 60041/08 (23/11/2010).

83 Bukta and Others v. Hungary 25691/04 (17/07/2007).

${ }^{84}$ Constitutional Court Decision no. 75/2008. (V. 29.).

85 Patyi and Others v. Hungary 5529/05 (07/10/2008).

${ }^{86}$ Constitutional Court Decision no. 36/1994. (VI. 24.).
} 
criminal offense of insult to an authority or an official which carried a heavier penalty than ordinary slander and defamation is incompatible with the freedom of expression as guaranteed in the Constitution and repealed the relevant provision of the Criminal Code. The CC asserted that with the annulling of the offense the reputation of public figures and those exercising official authority is protected under the general provisions of the Criminal Code on slander and defamation.

The decision of the CC also implicitly modified the provision on slander if committed to the detriment of officials and politicians. According to the relevant provision of the Criminal Code the offender was criminally liable of an allegation if that could impugn the honor of the injured party irrespective of the truthfulness of the allegation. However, the court could permit the defendant to prove the truthfulness of the allegation if this was justified by public or pressing private interest. If permission was granted and the defendant succeeded in proving the truthfulness of the slanderous allegation he/she had to be acquitted. Accordingly only proven truth precluded criminal liability. ${ }^{87}$

However, with respect to slanderous allegations made in respect of politicians and other public figures the CC asserted that the person making the allegation can be held criminally liable only if he/she knew that the statement was in essence untrue, or was only unaware of its untruthfulness because he/she failed to display the necessary care and circumspection incumbent upon him/her according to the relevant rules of his/her vocation or profession. Thus contrary to the text of the Criminal Code the $\mathrm{CC}$ recognized impunity also for false allegations provided that the injured party was a public figure and the defendant could not be blamed for negligence with regards to the error in fact.

The CC relied heavily on the case law of the ECtHR. It summarized and employed the principles developed by the Court on the scope and the limits of criticism infringing the honor of politicians and public officials in the leading cases such as Lingens v. Austria ${ }^{88}$, Castells v. Spain ${ }^{89}$ or Thorgeirson v. Iceland. ${ }^{90}$

In 2004 the CC - through the adoption of a constitutional requirement - extended the immunity of Members of Parliament on their expressions containing a value-judgment made against fellow MPs, politicians acting in public or persons exercising public power in the context of debates pertaining to public affairs. ${ }^{91}$ The CC reviewed the rules on the immunity of Members of Parliament in constitutional democracies and with reference to numerous judgments it summarized the Strasbourg case-law on politicians' freedom of speech. The CC stressed the importance of free debate of public affairs in Parliament and concluded that in the case of allegations that could impugn the honor of a politician the immunity of a Member of Parliament can be suspended only if he/she knew that the statement was, in essence, untrue. By this the CC further broadened impunity from prosecution for slander: Members of Parliament may not be held criminally liable for false allegations even if the error can be attributed to their failure to display the necessary care provided that the allegation concerns public affairs and is made against other politicians or persons exercising public power.

In sum, the ECtHR case-law via the decisions of the Constitutional Court has had considerable impact on raising awareness of the crucial place of uninhibited political speech in a democratic society. However, some recent legislative measures raise concerns and it may not be ruled out with certainty that the achieved standard in guaranteeing freedom of political speech will be lowered. As noted earlier the Venice Commission had criticized the provision of the Fourth Amendment of the FL, which prohibits the exercise of the right to freedom of speech "with the aim of violating the dignity of the Hungarian nation." The VC rightly fears that this provision could easily be abused for curtailing

\footnotetext{
${ }^{87}$ Act no. IV of 1978 on the Criminal Code, Section 232.

88 Lingens v. Austria 9815/82 (08/07/1986), A103.

${ }^{89}$ Castells v. Spain 11798/85 (23/04/1992), A236.

90 Thorgeir Thorgeirson v. Iceland 13778/88 (25/06/1992), A239.

${ }^{91}$ Constitutional Court Decision no. 34/2004. (IX. 28.).
} 
the criticism of the Hungarian institutions and office holders. The new Criminal Code penalizes the violation of not only the national anthem, the flag or the coat of arms of Hungary as did the previous Criminal Code, but also violation of the Holy Crown [Section 334 of Act no. C of 2012]. The Fourth Amendment to the FL brought about a rather problematic change to political advertisement during election campaign: parties and candidates may only publish political content through the public media, which as research and perception shows stands close and is loyal to the governing coalition. [Article IX (3)]

A third area where Strasbourg case-law has already strengthened democracy, openness and transparency is freedom of information. The judgment in Társaság a Szabadsagjogokért v. Hungary ${ }^{92}$ is regarded as a groundbreaking decision..$^{93}$ Társaság a Szabadságjogokért (TASZ-the Hungarian Civil Liberties Union) is an NGO promoting the rule of law and human rights. One can only praise TASZ for making - through litigation pursued - a remarkable contribution to the development of Article 10 jurisprudence. For the first time the Court recognized the right to access to public information when it stated: the state can not create undue barriers to the gathering of public information and through that to an informed public debate. The state can not impede the flow of information sought. In Kenedi the ECtHR ${ }^{94}$ found again violation of Article 10 for the failure of the authorities to respect the court decisions and grant access to information on the operation of the Hungarian State Security Service in the 1960s, which the applicant as a historian needed for his research.

Both the Társaság a Szabadságjogokert and the Kenedi judgment might have contributed to the growing awareness of the right to have access to public information. The number of cases brought before courts was significantly increased when in 2010 atlatszo.hu (átlátszó means transparent in Hungarian) was established. It was launched by a group of pro-transparency and anti-corruption journalists, lawyers, experts, etc., and serves as an online portal for investigative journalism. Atlatszo.hu has generated a large number of cases drawing attention to corruption and the lack of transparency. Atlatszo.hu in May 2013 won a landmark case against a company providing meal, travel, etc. vouchers, where the court found: "since the company is using public funds, all and any financial data is public interest" ${ }^{95}$ Although the willingness to release public data has been growing, there are still many cases where public authorities need to be taken to court to comply with their obligation. It is also rather disquieting that after an NGO coalition filed a petition to receive the public information related to the state monopolization of tobacco sale, the Parliament amended the freedom of information act in order to limit "excessive" or "abusive" request of public data. ${ }^{96}$

\section{Conclusion}

In 2012 Gábor Kardos, professor of international human rights law, recalled the concerns voiced by Western European experts more than twenty years ago when the accession of the former Communist countries of Eastern Europe had been put on the agenda. He also made an attempt to assess taking Hungary as the example whether the concerns have proven to be valid or not. ${ }^{97}$ As Kardos observes it was feared that the accession of the transition countries would lower the level of protection reached by the early 90's resulting in the alienation of the old state parties from their

\footnotetext{
92 Társaság a Szabadságjogokért v. Hungary 37374/05 (14/04/2009).

93 Petra Bárd, 'Hungary' in: Leonard Hammer and Frank Emmert (eds.), The European Convention on Human Rights and Fundamental Freedoms in Central and Eastern Europe (The Hague: Eleven Publishing, 2012), p. 241.

${ }^{94}$ Kenedi v. Hungary 31475/05 (26/05/2009).

95 See: http://atlatszo.hu/2013/07/16/budapest-metropolitan-court-decided-against-secretive-state-ownedcompany/.

${ }^{96}$ Also known as Lex Átlátszó. The text of the amendment: http://www.parlament.hu/irom39/10904/10904.pdf.

97 Gábor Kardos, 'Az Emberi Jogok Európai Bírósága és Magyarország: Jogi kultúra és hatékonyság' [The European Court of Human Rights and Hungary: Legal Culture and Efficiency], Kriminlógiai Közelmények (Magyar Krtiminológiai Társaság, 2012), 205-207.
} 
own human rights protection system. It was also anticipated that as a result of the applications from the new Member States the Court would be confronted with problems of basically political nature such as the protection of minorities, compensation for property nationalized after World War 2 or difficulties arising from prosecution of crimes committed under the Communist regime. This - in the skeptics' view - would have hindered the Court in further refining its jurisprudence on human rights problems arising in the context of established democracies of Western Europe. As regards the Hungarian experience Kardos concludes that the fears and concerns have proven to be unfounded. The Court was successful in avoiding the use of a "double standard" and the judgments rendered in respect of Hungary have not lowered the level of protection. The Court, of course, was confronted with cases that had their source in the Communist past. In Rekvényig8 the Court accepted the restriction imposed on police persons' political activities taking into account - among others - the difficulties new democracies were faced with in the period of transition. However, the Court in Vajnai and Fratanolo made it clear that the historical experience of a nation that it was prepared to consider right after the collapse of the Communist regime when assessing the necessity of the interference may no longer be invoked with the passing of time when the country had become a stable democracy.

The ECtHR has contributed to strengthening democracy in Hungary through among others judgments concerning the right to vote, freedom of expression and access to information. Its jurisprudence has become part of Hungarian legal culture. Mandatory, restricted elective or elective courses on various aspects of Strasbourg case-law are offered at all law faculties in the country and by the recently established Human Right MA program of the Social Science Faculty of the Eötvös Loránd University. Strasbourg case-law is regularly invoked by the Hungarian Constitutional Court and human rights NGOs, and an increasing number of attorneys use frequently ECtHR jurisprudence in litigation before domestic courts. The National Academy of Justice offers training courses on various aspects of Strasbourg case-law. Courts from time to time invoke ECtHR judgments but this is certainly not the rule. However, research indicates that also in the Western European democracies it took for judges two decades to regularly rely on judgments of the Strasbourg Court. ${ }^{99}$

Strasbourg judments are duly implemented and legislation is amended if required for ensuring compliance with the ECHR. The resolution adopted following the Fratanoló judgment in which Parliament expressed its disagreement and its resolve not to amend the Criminal Code is definitely the exception.

In certain areas general measures have to be taken in order to prevent multiple violations in the future. Thus, in order to prevent future Article 3 violations prison conditions have to be improved and the incidences of excessive police violence the victims of which are mostly members of the Roma community must be reduced through - among others - intensive training and effective investigation into the allegations of police brutality.

Since structural deficiencies may not be corrected overnight we may expect a further increase in the number of applications. Also, some recent amendments to the Fundamental Law, which fail to comply with the European standards set for example in the judgments of the ECtHR, the narrowing down of the competence of the Constitutional Court, the incorporation of provisions of law found to be unconstitutional by the CC into the FL itself and laws adopted on the basis of the FL, such as the provision in the Criminal Code on mandatory life imprisonment ${ }^{100}$ or the law criminalizing homelessness ${ }^{101}$ are likely to contribute to a further increase of the workload of the Strasbourg Court.

\footnotetext{
98 Rekvényi v. Hungary 25390/94 (20/05/1999), Reports of Judgments and Decisions 1999-III.

99 Gábor Kardos, 'Az Emberi Jogok Európai Bírósága és Magyarország: Jogi kultúra és hatékonyság' [The European Court of Human Rights and Hungary: Legal Culture and Efficiency], 'Kriminlógiai Közelmények' (Magyar Krtiminológiai Társaság, 2012), 207.

${ }^{100}$ Act no. C of 2012,. Section 90 (2)
} 
${ }^{101}$ Section 1 of Act no. CLIII of 2011 amending Act no. LXIX of 1999 on Petty Offenses 


\title{
LATVIA
}

\author{
Martins Mits*
}

\section{Consolidating democratic changes in Latvia: the various roles of the European Convention on Human rights}

\section{Introduction}

Latvia ratified the European Convention on Human Rights (ECHR) and its Protocols No. 1, 2, 4, 7 and 11 on 4 June 1997. It took almost two and a half years for Latvia to accede to the ECHR, instead of one year, as it was expected from joining the Council of Europe in 1995. Compatibility review of domestic legislation with the ECHR prior to its ratification was lengthy and, as it later turned out, it did not adequately address the country's heaviest problems in the area of criminal procedure.

At the same time, ratification of the ECHR coincided with drafting of the national catalogue of human rights - Chapter 8 of the Constitution. The Latvian legal system was in the process of discovering international law. Re-introduction of the Satversme (Constitution) from 1922, the need to facilitate smooth transition from the Socialist law to that of the modern Continental Europe and lack of corresponding human rights traditions set ground for potentially deep influence of the ECHR. It was even suggested in scholarly writings that the ECHR had to become a guideline for determining fundamental values of the society.

There are areas where such an influence can be identified. Through the judgments of the European Court of Human Rights (ECtHR) involving Latvia the ECHR made a deep impact on due process guarantees in criminal procedure, balancing of freedom of expression with protection of private life and contributed to searching for a delicate balance in lustration proceedings. Besides, the ECHR has served as the last bastion for domestic courts in socially sensitive questions of freedom of assembly in absence of rulings against Latvia by the ECtHR. Similarly, the ECHR has served as a pillar for domestic courts for raising domestic standards regarding poor prison conditions.

The Latvian judges have accepted the ECHR. Case law of the ECtHR is followed irrespective of the country concerned. The newly established courts - the Constitutional Court and Administrative Cases Department of the Supreme Court - use the ECHR as a tool for interpretation of standards and methodology of the domestic legal provisions to the extent that its role becomes similar to that of a textbook. Downside of this overall acceptance, though, is the application of the ECHR on a level of its literal reading or as an argument for blocking judicial law-making. There are different dynamics of application of the ECHR within the Supreme Court and this captures the fact that the Latvian legal system today is a mixture of elements inherited from legal positivism of the Socialist law and from a comparatively flexible system of Civil law penetrating Latvian legal system also through the ECHR.

The pragmatically open use of the ECHR as a daily working tool by a part of judiciary is something that Latvia may offer in return to the ECHR system. Besides, such cases as Kononov v. Latvia and Ždanoka v. Latvia reminds the ECtHR about the importance of application of the ECHR in a broader framework of international law and with due regard of the historical details that determine today's conduct.

Overall, the ECHR has made a positive contribution on consolidating democratic changes in Latvia on various levels - legislation, judiciary, civic activism and through shaping the values of the society. It will be attempted to explore these impacts and to see whether there is a room for the further expansion. 


\section{Historical aspects of accession to the ECHR}

\subsection{Overview of the constitutional order}

Latvia is a parliamentary democracy and Satversme (the Constitution) was adopted on 15 February 1922. The Republic of Latvia was proclaimed on 18 November 1918, but its de facto existence was interrupted by incorporation into the Union of Soviet Socialist Republics (USSR) starting from 17 June 1940. Latvia followed the doctrine of state continuity and viewed its Constitution and other legal acts as de jure in force during the occupation by the USSR (and by Nazi Germany from 1941-1944). ${ }^{102}$ De facto force of the Constitution was fully restored on 6 July 1993 on the day of the first session of the Saeima (the Parliament) elected in free elections after the restoration of independence.

The principles and structures laid down in the Constitution were considered so up-to-date and efficient that majority of lawyers and politicians did not see an immediate need to change them. Thus, unlike in the neighbouring Baltic countries, there was not a new constitution adopted following restoration of independence in the beginning of 1990ies. This and the fact that the Constitution was supplemented with Chapter 8 "Fundamental Human Rights" - a national catalogue of human rights only in 1998, was one of the factors that made Latvian legal system open to international law and direct application of international human rights treaties.

The powers are shared among the Parliament, consisting of 100 members who are elected for a period 4 years based on proportional representation, the Cabinet of Ministers (the Government) consisting of the Prime Minister and 13 ministers, as well as the judiciary. The Prime Minister is nominated by the President who is the Head of a State. The President is elected by the Parliament for a period of 4 years and, apart from the representative functions, he possesses important tools of the qualified right to veto laws and initiate dismissal of the Parliament. The latter right was exercised recently, and, as a reaction to deep distrust to politicians and public institutions in general, the people of Latvia for the first time dismissed the Parliament through a public referendum in July 2011.

The judiciary is comprised of the Constitutional Court and courts of general jurisdiction. The Constitutional Court has 7 judges and it was established in $1996 .{ }^{103}$ It exercises abstract judicial review over compliance of legal norms with higher legal norms that may be initiated by a wide range of subjects. Notably, since 2000 individuals may submit constitutional complaints about alleged violations of their fundamental rights set out in the Constitution.

There is a three-tiered court system with 35 district/city courts, 6 regional courts and the Supreme Court hearing civil, criminal and administrative cases. ${ }^{104}$ Administrative courts were introduced in 2004 with the entry into force of entirely new Administrative Procedure Law. Therefore administrative courts have distinctive structure with one district court and five regional branches and one regional court dealing exclusively with administrative cases while the rest of district/city and regional courts deal with both civil and criminal cases. The Supreme Court has a Senate with three departments (civil, criminal and administrative) acting as a court of cassation and two Chambers for civil and criminal cases acting as a court of appeal in certain cases. Both Chambers are going to be gradually abolished and starting from 2017 the Supreme Court will have only three departments acting as a court of cassation. ${ }^{105}$

\footnotetext{
102 On Latvia's claim to state continuity see Ineta Ziemele State Continuity and Nationality: the Baltic States and Russia, Martinus Nijhoff Publishers: Leiden, 2005, in particular, 31-36.

${ }^{103}$ Satversmes tiesas likums [Law on the Constitutional Court], adopted on 5 June 1996, published in Latvijas Vēstnesis [Official Gazzette] No. 103, 14 June 1996.

104 Likums "Par tiesu varu" [Law on Judical Power], adopted on 15 December 1992, published in Zinotājs [Official Reporter] No. 1, 14 January 1993.

${ }^{105}$ Grozijumi likumā par tiesu varu [Amendments to the Law on Judicial Power] Latvijas Vēstnesis [Official Gazzette] No. 128, 4 July 2013, Article 32 (paragraph 57 in transitional provisions).
} 


\subsection{The status of the ECHR in the domestic order}

\subsubsection{Relationship between domestic and international Law}

The relationship between domestic and international law in Latvia is best characterised by two phrases: openness and lack of clear regulation. Openness was largely determined by the need to have legal standards in place that would help transforming legal system in the beginning of 1990-ies as fast as possible. The lack of a clear regulation, in its turn, was largely influenced by the fact that Latvia chose to restore its Constitution from 1922 where this question was not expressis verbis regulated.

The starting point is Article 1 of the Declaration on the Renewal of Independence of the Republic of Latvia (the Independence Declaration) in which the Parliament (then - the Supreme Soviet of the Latvian Soviet Socialist Republic) undertook:

"To recognize the supremacy of the fundamental principles of international law over national law. (...)"106

As it was later explained by one of the drafters of the Independence Declaration, by the "fundamental principles of international law" the drafters meant ius cogens norms, international customary rules and general principles of law recognised by civilised nations. ${ }^{107}$ Since the Independence Declaration itself had a constitutional status, there is a strong basis for an argument that the said sources of international law are directly applicable and their legal force is at least equal to that of the Constitution.

Among all sources of international law the highest practical significance has the question of the place of international treaties in the hierarchy of domestic legal norms. The Constitution, unlike with other sources of international law, does address the question of international treaties, but only from the point of view of the procedure. Article 68(1) of the Constitution states:

"The ratification of the Saeima [the Parliament] shall be indispensable to all international agreements dealing with matters to be settled by legislation." ${ }^{\prime 108}$

This means that all international treaties dealing with questions normally falling within the competence of the Parliament, including protection of human rights, must be reviewed and ratified by the Parliament. The ratification takes the form of passing a law that contains a brief statement that the treaty has been approved, with the text of the treaty attached in the original and Latvian languages. This suggests that international treaties after ratification have equal status to the laws passed by the Parliament. It seems that such reading of Article 68(1) was followed by the Parliament when it adopted Law on the International treaties of the Republic of Latvia in 1994 affording priority to provisions of the ratified international treaties over domestic laws in case of a conflict. ${ }^{109}$ The Law on the International treaties of the Republic of Latvia acknowledged direct applicability of international treaties on domestic level.

106 Deklarācija Par Latvijas Republikas neatkarības atjaunošanu [Declaration On the Renewal of Independence of the Republic of Latvia] Zinotājs [Official Reporter] No. 20, 17 May 1990.

107 Egils Levits "Cilvēktiesību normas un to juridiskais rangs Latvijas tiesību sistēmā" [Human Rights Norms and their Legal Rank in the Latvian Legal System] Juristu Žurnāls Nr.5 / Cilvēktiesību Žurnāls Nr.6 [Law Journal No.5 / Human Rights Quarterly No.6] 1997, 49-50.

108 Latvijas Republikas Satversme [Constitution of the Republic of Latvia] Latvijas Vēstnesis [Official Gazzette] No. 43, 1 July 1993.

${ }^{109}$ Article 13 of the Law on the Republic of Latvia International Treaties reads:

"If an international treaty approved by the Saeima [the Parliament] provides for other provisions than those in the Republic of Latvia legislative acts, the provisions of the international treaty shall be applied." Likums "Par Latvijas Republikas starptautiskajiem līgumiem" [Law on the Republic of Latvia International Treaties] Latvijas Vēstnesis [Official Gazzette] No. 11, 26 January 1994. 
However, this is only one of the possible models of the relationship between binding international treaties and laws passed by the Parliament. The work of the Constitutional Court and development of legal doctrine in the area of human rights law indicate two other possible models.

The competence of the Constitutional Court was defined, inter alia, as follows: compliance of laws passed by the Parliament has to be reviewed against the Constitution, compliance of domestic legal norms (including laws passed by the Parliament) has to be reviewed against those international agreements that are in compliance with the Constitution, compliance of signed or binding international treaties has to be reviewed against the Constitution. ${ }^{110}$ The logics of the set competence implies hierarchical relationships where the Constitution is on top, international treaties between the Constitution and the laws, and laws passed by the parliament below international treaties and the Constitution. Such reading of the Law on the Constitutional Court means that binding international treaties have priority over laws passed by the Parliament by virtue of their higher legal rank and not because rule of the collision affording priority to the norms in the international treaty in the case of a conflict as it was discussed above.

It is important to note that Judge Juris Jelāgins in his separate opinion specifically addressed this question in 2004. ${ }^{111}$ His reading of the Law on the Constitutional Court was based on the first model discussed above: since international treaties after ratification acquire the same legal rank as a law passed by the Parliament then the Constitutional Court does not have competence to examine submissions concerning compliance of laws passed by the Parliament against binding international treaties. It is because such conflict is between legal norms of the same legal rank, while the Constitutional Court is mandated to examine disputes between norms with a different legal force. ${ }^{112}$ Notably, the majority of judges did not follow this line of reasoning, they found the submission admissible and decided that provisions of the Code of Administrative Violations (law passed by the Parliament) were contrary to the provisions of the Convention on Facilitation of International Maritime Traffic (international treaty ratified by the Parliament). ${ }^{113}$ This gives strength to an argument that the majority of the judges of the Constitutional Court viewed the legal rank of international treaties as being above the laws passed by the Parliament, but below the Constitution.

Both discussed models approach the question of the place of international treaties from the point of view procedure how international treaties enter into the Latvian legal system. Another approach developed in the area of human rights and it looked upon the place of international treaties from the point of view of the subject matter regulated.

Since the Constitution did not contain a national catalogue of human rights such a catalogue was adopted in the form of a Constitutional Law on the Rights and Obligations of a Citizen and a Person on 10 December 1991 (the Constitutional Law). ${ }^{114}$ Despite its title, the constitutionality of the Constitutional Law could be challenged. The Constitution did not provide for such category as

\footnotetext{
110 Article 16 of the Law on Constitutional Court reads:

"The Constitutional Court shall review cases regarding:

1) compliance of laws with the Constitution;

2) compliance of international treaties signed or concluded by Latvia (including treaties that have not been accepted by the Parliament yet) with the Constitution; (...)

6) compliance of the national legal norms of Latvia with the international treaties concluded by Latvia, which are not contrary to the Constitution."

111 Dissenting Thoughts of Judge Juris Jelāgins to the Judgement of the Constitutional Court No. 2004-01-06, 7 July 2004, par. 4 and 6.

112 In another separate opinion Judge Jelāgins confirmed the previously expressed view that the Constitutional Court only has the competence to examine cases involving legal norms of a different legal force. Dissenting Thoughts of Judge Juris Jelāgins to the Judgement of the Constitutional Court No. 2008-35-01 (Lisbon Treaty Case), 21 April 2009.

113 Judgement of the Constitutional Court No. 2004-01-06, 7 July 2004.

114 Konstitucionālais likums "Cilvēka un pilsoṇa tiesības un pienākumi" [Constitutional Law on the Rights and Obligations of a Citizen and a Person] Ziṇotājs [Official Reporter] No. 4, 30 January 1992.
} 
"constitutional laws" and it was adopted in the Parliament with a simple majority vote depriving this law of a "strong legitimacy" argument. In order to provide safe ground for the protection of human rights, a noteworthy doctrine was developed relying on the concept of "democracy".

The essence of this doctrine can be summarized as follows: protection of human rights is an inalienable feature of any democratic state governed by the rule of law; this means that human rights have to take precedence over ordinary laws, otherwise protection of human rights would be in constant danger; the core of human rights has to be recognized by any democratic state, but the national catalogues may go further than the core; the Constitutional Law makes it clear which rights are considered as fundamental rights in Latvia and the concept of "democracy" laid down in Article 1 of the Constitution ${ }^{115}$ affords constitutional rank to the Constitutional Law. ${ }^{116}$ In a nutshell, this means that human rights laid down in the Constitutional Law had constitutional status and priority over laws passed by the Parliament because the protection of human rights is a fundamental principle of a modern democratic state governed by the rule of law and because it is rooted in the concept of "democracy" in Article 1 of the Constitution.

This doctrine was applied also to binding international human rights treaties, affording them constitutional rank alongside with the Constitutional Law because of their subject matterprotection of human rights. ${ }^{117}$ More so, it was applied beyond the scope of human rights arguing that any binding international treaty that regulated matters covered by selected articles in the Constitution because of its object and purpose would have priority over laws passed by the Parliament. ${ }^{118}$

This approach advocated by legal scholars in the area of human rights was shared by the Parliament. When the Constitution was finally supplemented with a chapter on human rights in 1998, Article 89 referred to binding international treaties alongside with the Constitution and domestic laws:

"The State shall recognise and protect fundamental human rights in accordance with this Constitution, laws and international treaties binding upon Latvia."119

As a minimum, this article lays down constitutional obligation to ensure protection of human rights on the level of binding international standards, but it does not preclude domestic standards from going further. It also implies obligation to interpret domestic (constitutional) and international norms in harmony to avoid conflicts between them - the Constitutional Court soon developed so called principle of "harmonious interpretation" and in its work extensively relied on it. Article 89 also implied that binding international treaties could be directly applied on domestic level - courts of general jurisdiction gradually started to apply international treaties since mid 1990-ies.

To summarise, the Latvian legal system developed in the way that acknowledged direct applicability of international law and priority of international law over domestic law (except the Constitution). There are three possible models how the relationship between laws passed by the Parliament and

\footnotetext{
${ }^{115}$ Article 1 of the Constitution reads:

"Latvia is an independent democratic republic".

116 Egils Levits "Interpretation of Legal Norms and the Notion of "Democracy" in Article 1 of the Satversme" Latvian Human Rights Quarterly No. 1, 1997, 67-70.

117 Egils Levits "Eiropas Cilvēktiesību konvencijas piemērošana Latvijas iestādēs un tiesās" [Application of the European Convention of Human Rights in the Latvian courts and administrative authorities] in Ineta Ziemele (ed.) Cilvēktiesību istenošana Latvijā: tiesa un administratīvais process [Implementation of Human Rights in Latvia: Judiciary and Administrative Procedure], Latvian Human Rights Institute: Riga, 1998, 58; Ineta Ziemele "Rasu diskriminācijas aizliegums Latvijas tiesību sistēmā un praksē" [Prohibition of Racial Discrimination in the Latvian Legal System and the Practice] Likums un Tiesïbas [Law and Justice] No. 11, 2004, 331.

118 Ineta Ziemele "Starptautiskās tiesības Latvijas tiesību sistēmā un tiesu un administratīvajā praksē" [International Law in the Latvian Legal System and Its Application by the Courts and Administration] in Ineta Ziemele (ed.) Cilvēktiesību istenošana Latvijā: tiesa un administratīvais process [Implementation of Human Rights in Latvia: Judiciary and Administrative Procedure], Latvian Human Rights Institute: Riga, 1998, 43.

${ }^{119}$ Grozijumi Latvijas Republikas Satversmē [Amendments in the Constitution of the Republic of Latvia] Latvijas Vēstnesis [Official Gazzette] No. 308, 23 October 1998.
} 
binding international treaties can be seen: treaties have the same force as laws, treaties are placed between laws and the Constitution, the place of the treaties depends on the subject matter regulated. The latter approach was developed by legal scholars in the area of human rights and it is supported by the text of Article 89 of the Constitution. ${ }^{120}$ Thus, binding human rights treaties have constitutional status.

\subsubsection{Status of the ECHR in the national legal order}

The ECHR and its Protocols No. 1, 2, 4, 7 and 11 were ratified by the Parliament on 4 June 1997.121 When ratifying the ECHR and its protocols, Latvia made a reservation exempting application of Article 1 of Protocol No.1 (property rights) to the matters of property reform. ${ }^{122}$ The Parliament also recognised competence of the Commission and the ECtHR to deal with individual applications involving Latvia, but this question was surrounded by controversy and it captures the general tone of discussing important questions of international treaty law at the time of active transition from Socialist legal system to that of continental Europe in mid 90ies.

When the Law on the European Convention for the Protection of Human Rights and Fundamental Freedoms of 4 November 1950 and its Protocols No.1, 2, 4, 7 and 11 (the Ratification Law) was discussed during the second and the final reading in the Parliament, Antons Seiksts, Chairman of the Committee of Human Rights and public Affairs of the Parliament who was in charge of the Ratification Law, made the following statement during the debates:

“(...) Jurisdiction of the Council of Europe enters into force in Latvia in three years. This is the term during which we still can set everything in order. (...) We have already exceeded the time limit and at the moment none of the articles take effect in a way that binds Latvia socially or politically."123 (Author's translation)

The Chairman of the responsible committee was of the opinion that there were three more years during which Latvia could harmonise its laws with the ECHR, but the European Commission of Human Rights (Commission) and the European Court of Human Rights (ECtHR), seemingly, would not have competence to deal with individual applications. This matter was not discussed further and the Ratification Law was adopted.

This statement could be explained, if the relevant articles of the Ratification Law, whose object and purpose was to recognise the competence of the Commission and the ECtHR to receive complaints against Latvia, were read as not recognising the competence for a period of three years, but only after three years from the ratification of the ECHR. ${ }^{124}$ However, it is clear that, following recommendations of the Parliamentary Assembly and prior to entry into force of Protocol No.11, the intention was to recognise immediately the competence of the Commission and the ECtHR to deal

${ }^{120}$ As the latest authority see Ineta Ziemele and Daiga Rezevska "15.pants [Article 15]" in Jautrīte Briede (Ed.) Administratīvā procesa likuma komentāri: $A$ un B dalas [Commentary to Administrative Procedure Law: Parts $A$ and B], Tiesu namu aǵentūra: Riga, 2013, 232-233. The authors argue that, in order to determine the place of international treaties, not only procedure of ratification is relevant, but also the subject-matter and that binding human rights treaties have constitutional status.

121 Likums "Par 1950.gada 4.novembra Eiropas Cilvēka tiesību un pamatbrīvību aizsardzības konvenciju un tās 1., 2., 4., 7. un 11.protokolu" [Law on the European Convention on Human Rights and Fundamental Freedoms and Its Protocols No.1, 2, 4, 7 and 11] Latvijas Vēstnesis [Official Gazzette] No. 143/144, 13 June 1997.

122 Reservation contained in Note Verbale from the Minister of Foreign Affairs of Latvia is available at: http://conventions.coe.int/Treaty/Commun/ListeDeclarations.asp?CL=ENG\&NT=009\&VL=1.

123 “Eiropas padomes jurisdikcija Latvijā stājas spēkā trīs gados. Šis terminš̌ ir laiks, kurā mēs vēl varam visu sakārtot. (...) Mēs esam jau pārtērējuši laika limitu, un šobrīd neviens no pantiem nestājas spēkā tādā veidā, kas Latviju saistītu sociālā vai politiskā ziñā." (Original text in the Latvian language). Latvijas Republikas 6. Saeimas pavasara sesijas četrpadsmitās sēdes stenogramma [Transcript of the $14^{\text {th }}$ Meeting of the Spring Session of the Sixth Saeima of the Republic of Latvia], 4 June 1997, Latvijas Vēstnesis [Official Reporter] No. 139/140, 10 June 1997.

${ }^{124}$ See the text of Article 4 of the Ratification Law recognising competence of the ECtHR in chapter 4.2 below. 
with individual applications under Articles 25 and 46 of the ECHR respectively. This is clearly reflected in the text of declarations contained in a Note Verbale from the Minister for Foreign Affairs of Latvia and deposited together with the instrument of ratification. ${ }^{125}$ Likewise, the ECtHR did not hesitate to deal with applications from Latvia within a three years period following ratification of the ECHR. ${ }^{126}$

It could be argued that this is an accurate illustration, on the one hand, of the primary interest of the political elite (and the public at large) to be part of the modern Europe and, on the other hand, the secondary interest attached to the scope of legal obligations that this entails. The ratification of the ECHR at the Parliament was surrounded by ambiguity as to when Latvia has to comply with its obligations.

Irrespective of this ambiguity, the ECHR after ratification was directly applicable and had constitutional status. While the ECHR was one of the many human rights treaties and it was not spelt out among other treaties on the level of legislation, it did have a special standing among other treaties when it came to its application in the courts.

This is particularly evident in the work of the Constitutional Court as illustrated by a study examining application of international human rights treaties by the Constitutional Court during the first nine years of its work (from 1997 until 1 April 2006). ${ }^{127}$ Altogether the Constitutional Court referred to international human rights treaties in 74 judgments. The ECHR was referred to in 49 cases (11 upon the initiative of the applicants). By comparison, the International Covenant on Civil and Political Rights (ICCPR) was referred to in 30 cases (4 upon the initiative of the applicants). The difference between the two treaties is not striking, however, it is growing in favour of the ECHR when a more detailed analysis is undertaken. Thus, contents of ECHR standards were clarified with a reference to scholarly writings or case law of the ECtHR (or the Commission) in 38 cases. Contents of ICCPR standards were clarified on the basis of scholarly writings or documents produced by the Human Rights Committee in 11 cases. References to case law of the ECtHR more than twice in one judgement were made in 24 cases while there were no references made more than twice to scholarly writings or documents under ICCPR at all. ${ }^{128}$

References to case law and scholarly writings indicate a pragmatic interest to clarify contents or methodology of application of legal provisions. The above study showed that the ECHR was the most extensively applied international human rights treaty by the Constitutional Court, it was also the most often invoked treaty by the applicants. ${ }^{129}$

More recent study on the application of the ECHR by the Supreme Court (from 1 January 2011 till 17 August 2012) reveals diverse picture with respect to its application by the three departments. In Criminal Law Department contents of the ECHR standards were clarified with reference to case law of the EC/tHR in 6 out of 56 cases where ECHR was referred to ( 3 upon the initiative of the applicants), in Civil Law Department - in 25 out of 60 cases (11 upon initiative of the applicants); in Administrative Law Department - in 40 out of 54 cases ( 7 upon initiative of the applicants). ${ }^{130}$

\footnotetext{
125 Declaration contained in Note Verbale from the Minister of Foreign Affairs of Latvia is available at: http://conventions.coe.int/Treaty/Commun/ListeDeclarations.asp?PO=LAT\&NT=005\&MA=999\&CV=0\&NA=EX$\underline{25 \& C N=999 \& V L=1 \& C M=5 \& C L=E N G}$.

126 The earliest admissibility decision involving Latvia considered by the Court was the case Pancenko v. Latvia Application No. 40772/98 introduced on 16 December 1997, registered on 15 April 1998, and decided on 28 October 1999.

127 Martins Mits European Convention on Human Rights in Latvia: Impact on Legal Doctrine and Applications of Legal Norms, Media Tryck: Lund, 2010, 150.

128 Ibid.

129 By way of comparison, International Covenant on Economic, Social and Cultural Rights was invoked by applicants in 1 case and referred to by the Constitutional Court in 12 cases, Universal Declaration of human rights - not invoked by applicants, but referred to in 17 cases, European Social Charter - not invoked, but referred to in 8 cases and European Union Charter of Fundamental Rights - not invoked, but referred to in 4 cases.

130 Martins Mits Eiropas Cilvēktiesību tiesas judikatūra Latvijas Republikas Augstākās tiesas nolēmumos [Case
} $-24 / 240-$ 
There is a very high number of cases in the Administrative Law Department where the contents of ECHR were clarified with a reference to case law of the ECtHR and usually it was done on the initiative of judges themselves. Similar situation was in the Constitutional Court discussed above. Such extensive use the ECHR suggests that it fulfilled a role of a "textbook". References to case law of the EC/tHR were mostly used to clarify contents of the standards in the ECHR (more seldom methodology for application of ECHR standards) in order to interpret in the same way contents (methodology for application) of human rights provisions contained in the Constitution or in laws passed by the Parliament.

This also shows that the ECHR de facto was equally important to the Constitution, supporting the argument about the constitutional status of the human rights treaties. The Constitutional Court, however, has clearly indicated, with a reference to the German Federal Constitutional Court, that the ECHR has to be used for interpretation of the provisions of the Constitution only "as far as possible", leaving to the Constitution the role of the supreme law. ${ }^{131}$ At the same time, the Constitutional Court has always followed a principle of harmonious interpretation of domestic legal provisions (including the Constitution) with the ECHR and has avoided conflicts.

To summarise, the ratification of the ECHR in the Parliament was surrounded by ambiguity as to when Latvia has to start complying with its obligations. Irrespective of this, the ECHR like other binding human rights treaties was directly applicable and had constitutional status. The ECHR stood out among other human rights treaties when it came to its application - in the work of the Constitutional Court and Administrative Cases Department of the Supreme Court the ECHR had an influence that exceeded the traditional function of an international treaty - it fulfilled a role of a "textbook." The ECHR de facto was equally important as the Constitution and it has had a strong influence on the interpretation and application of human rights provisions contained in the Constitution.

\subsection{Mechanisms of implementation and coordination}

\subsubsection{Legislative level}

The Rules of Procedure of the Parliament in Article 85(5) set requirement that annotation accompanying any draft law submitted by eligible entities (the President, Parliamentary Committee, five Members of the Parliament) must, inter alia, provide an answer to the question: "How does the law conform to the international obligations assumed by Latvia?"132 Although the ECHR is not specifically spelled out, it is covered by the question. The Government is also entitled to submit draft laws and it is required to provide more detailed information concerning compliance with the ECHR. ${ }^{133}$

An obligation to prepare an annotation rests with the relevant subject submitting draft law. Nobody is required to check how diligently or whether at all this requirement has been complied with. Apart from this obligation, the Legal Office of the Parliament independently is required to carry out a general monitoring whether the draft law complies with the Constitution, binding international agreements and legal system in general - this follows from Article 89 of the Constitution and it is spelled out also in the internal rules of procedure of the Legal Office of the Parliament. ${ }^{134}$

There is only one entity - the people - that may submit draft laws for approval in the Parliament without annotation. According to Article 78 of the Constitution, one tenth of eligible voters are

Law of the European Court of Human Rights in Decisions of the Supreme Court of the Republic of Latvia], Supreme Court of the Republic of Latvia, December 2012, para. 1 and 7 of the Conclusions, available at: http://at.gov.lv/lv/judikatura/tiesu-prakses-apkopojumi/citi/.

131 Judgement of the Constitutional Court No. 2001-08-01, 17 January 2002, para.3.

132 Saeimas kārtības rullis [Rules of Procedure of the Parliament] Latvijas Vēstnesis [Official Gazzette] No.96, 18

August 1994.

133 See chapter 2.3 .2 below.

134 Interview with Gunārs Kusinšs, Head of the Legal Office of the Parliament, 7 October 2013. 
entitled to submit a draft law. However, also in this case the Legal Office of the Parliament is required to provide its opinion on compliance of the draft law with, inter alia, binding international treaties.

To summarise, there is a double check mechanism on compliance of draft laws with binding international treaties (except the draft laws submitted by the people). The parliamentary subjects entitled to submit draft laws have a general obligation to reflect impact of the draft law on Latvia's international obligations. The Legal Office of the Parliament independently carries out such impact assessment. There is no obligation to single out the ECHR among other binding international treaties or to pay particular attention to ECtHR's case law.

\subsubsection{Executive level}

Draft laws that are initially prepared on the level of ministries must also contain annotation. According to Article 3 of the Rules of Procedure of the Government all draft laws submitted for review by the Government must include annotation. ${ }^{135}$ There is an instruction issued by the Government providing detailed regulation of what annotation must contain. ${ }^{136}$ Chapter $V$ in annotation titled "Conformity of the draft legal act to the international obligations of the Republic of Latvia" contains three entries: obligations towards EU, other international obligations and other information. It is within the second entry "other international obligations" where obligations under ECHR primarily fit. Article 57.3 of the instruction specifically points out that conformity with case law of, inter alia, the EC/tHR has to be addressed. However, this obligation to assess conformity with "other international obligations" can be read as very limited in scope. Article 57.1 of the instruction requires indication of those international instruments or documents "whose obligations are implemented or undertaken by the Republic of Latvia".

The above formulation suggests that it would be applicable only to cases when draft law is specifically intended to implement international obligations, for example, directly following from the ECHR or from ruling of the EC/tHR. According to Laila Medin, Deputy State Secretary of the Ministry of Justice, this exactly is the idea of the discussed provision. However, the Ministry of Justice applies broader interpretation and carries out assessment, reflecting it in annotation, also in case when draft law might have negative impact on the obligations under the ECHR. ${ }^{137}$

Despite the broad interpretation applied, there may be several factors, including the discussed narrow wording of the obligation, that may preclude broader assessment of the possible negative impact of a draft law on obligations under the ECHR. An Extradition Treaty between the Government of the United States of America and the Government of the Republic of Latvia (the Extradition Treaty) concluded in 2006 serves as a good illustration. The need for concluding new Extradition Treaty arose from Latvia's membership in the European Union. Despite the fact that the Extradition Treaty was related to several fundamental rights and freedoms regulated under the ECHR, including the prohibition of death penalty, the annotation accompanying draft law on the Extradition Treaty stated that the draft law does not deal with obligations towards international organisations. The old bilateral treaties between Latvia and USA were indicated as the only source among all bilateral or multilateral treaties that contain international obligations relevant for the present case. ${ }^{138}$

\footnotetext{
135 Ministru kabineta kārtības rullis [Rules of Procedure of the Government] Latvijas Vēstnesis [Official Gazzette] No. 58, 16 April 2009.

${ }^{136}$ Tiesību akta projekta sākotnējās ietekmes izvērtēšanas kārtība [Procedure of the Initial Impact Assesment of a Draft Legal Act] Latvijas Vēstnesis [Official Gazzette] No. 205, 30 December 2009.

137 Interview with Laila Medin, Deputy State Secretary of the Ministry of Justice, 8 October 2013.

${ }^{138}$ Likumprojekta „Par Latvijas Republikas valdības un Amerikas Savienoto Valstu valdības līgumu par izdošanu” anotācija, [Annotation of Draft Law "On the Extradition Treaty Between the Government of the Republic of Latvia and the Government of the United States of America"], available from the legislative database of the Parliament at: http://titania.saeima.lv/LIVS11/saeimalivs11.nsf/.
} 
Apart from that, there is no regular monitoring mechanism to assess the need for legislative amendments following judgements delivered against Latvia or the other member states. However, there is an informal joint working group with Representative of the Government of the Republic of Latvia before the International Human Rights Institutions (Representative of the Latvian Government) and the Ministry of Justice which meets several times a year and discusses topical questions in that regard. ${ }^{139}$ As a rule, initiative concerning legislative amendments following rulings of the ECtHR comes from the Representative of the Government before the ECtHR. ${ }^{140}$

To summarise, the obligation to assess the impact of draft law on obligations under the ECHR, including case law of the ECtHR, has been reflected in much more detail on the executive than on legislative level. Despite its narrow wording, it has been interpreted broadly to cover situations of the potential violations of the ECHR, however, there seems not be a uniform practice in this regard. There are no formal mechanisms established to assess the need for legislative changes following rulings of the ECtHR in the cases against Latvia or other countries. Such initiatives usually come from the Representative of the Latvian Government and there have been joint consultations established between the two involved ministries.

\subsubsection{Judiciary}

All procedural laws explicitly allow domestic courts to apply binding international treaties, including the ECHR. However, there is no uniform approach as regards express acknowledgment of the obligation to take into consideration case law of the ECtHR. All three procedural laws emphasize the need to take into account case law of the Court of Justice of the European Union when implementing EU law. ${ }^{141}$ Only Article 5(1) and (6) of the Civil Procedure Law is formulated in a way that lays down equal obligation to consider case law of the ECtHR as that of the Court of Justice of the European Union. ${ }^{142}$ Express acknowledgment of the need to consider case law the ECtHR (and other international courts) in the two other procedural laws would be advisable. This might have positive contribution towards increased use of case law of the ECtHR in particular in criminal cases where its application is rare..$^{143}$

All three procedural laws contain provisions allowing to re-open a case following the ruling from the ECtHR. ${ }^{144}$ The right to ask reopening rests with the affected person (prosecutor acts as a filter in criminal cases and he has the right to initiate re-opening himself). The regulation in the Administrative Procedure Law is more detailed. Besides providing for the right to the affected person to initiate re-start of administrative proceedings in public institution (Article $87(1(3))$ ) or in administrative court (Article 353(6)), there is also an obligation imposed on a public institution to restart administrative proceedings if it is necessary for the implementation of a judgement of the ECtHR (Article 88(2)). Thus, in principle the Latvian courts have tools for re-opening of a case if the ECtHR has specifically indicated such special measure in its judgement or if it follows from the reasoning.

Another important aspect has to be mentioned in the context of implementation. The Supreme Court on its home page maintains a database of translations of all the judgments and decisions of the ECtHR that have been translated into the Latvian language. ${ }^{145}$ This is done in cooperation with the

\footnotetext{
139 Interview with Laila Medin, Deputy State Secretary of the Ministry of Justice, 8 October 2013.

140 Ibid.

${ }^{141}$ Article 2(2) of the Criminal Procedure Law, Article 5(1) and (6) of the Civil Procedure Law and Article 15(4) of the Administrative Procedure Law.

142 Article 5 of the Civil Procedure Law reads:

"(1) Courts shall adjudge civil matters in accordance with laws and other regulatory enactments, international agreements binding upon the Republic of Latvia and the legal norms of the European Union.(...)

(6) In applying legal norms, the court shall take into account case law."

143 See chapter 4.2 below.

${ }^{144}$ Article 655(5) of the Criminal Procedure Law, Article 479(6) of the Civil Procedure Law and Articles 87(1(3)), $88(2)$ and 353(6) of the Administrative Procedure Law.
} 
Office of the Representative of the Latvian Government - the Ministry of Foreign Affairs supplies the translations. Importantly, the database includes all the judgements and selected decisions that the ECtHR has delivered against Latvia. It includes a limited number of case law against other countries as well that has been translated into the Latvian language. This is a very important tool for judges who write their decisions in the Latvian language, not to mention its utmost importance for those judges who do not master the English and (or) French language.

\subsubsection{Informal mechanisms}

It is not an easy task to take stock of informal channels that contribute towards ensuring compliance with the ECHR. There is no particular single mechanism that stands out among the various contributors. Therefore, each of the three actors will be briefly addressed: academia, NGOs and media.

Apart from teaching and scholarship discussed in chapters 6.1 and 6.2 below, a human rights discussion that has become an established tradition and is organised for a duration of more than seven years is worth of noting. This event brings together a Judge from Latvia to the ECtHR, Representative of the Latvian Government, academicians and representatives of the public institutions - each year with a different focus (the Constitutional Court, Ombudsperson, etc.) and an audience of legal practitioners - prosecutors, judges, advocates, representatives from the ministries, the Parliament, NGOs, academicians and students as well. A key component of this half-day event is a discussion of the latest rulings of the ECtHR against Latvia as well as other relevant developments in the ECtHR of interest for Latvia. The event has been established upon the initiative of the Latvian Judge, Ineta Ziemele, it has been organised by the Riga Graduate School of Law and has been supported by the Soros Foundation Latvia. It attracts attention not only of legal practitioners, but also the media and it helps efficiently to disseminate information about the causes for the established violations of the ECHR and to pose questions about the measures required to prevent violations in the future.

As regards NGOs, apart from strategic litigation briefly discussed in chapter 6.4 below, NGOs have been instrumental in using the ECHR and case law of the ECtHR in their advisory or lobbying work. There have been selected important judgments (e.g., Opuz v. Turkey, D.H. v. Czech Republic, etc.) translated and disseminated by NGOs, seminars and training programmes conducted, the standards of the ECHR being constantly referred to by the NGOs in the formal working groups established by public authorities where they have been invited to participate. As it was noted by Anhelita Kamenska, Director of the Latvian Centre for Human Rights, there are growing dynamics as regards the readiness to accept arguments presented by NGOs on the basis of the ECHR in the formal working groups; if an argument is based on specific case law of the ECtHR, the stronger is its impact. ${ }^{146}$

Media regularly report on the judgements delivered against Latvia. Undisputedly, this is an important positive contribution towards raising public awareness about the problems identified and, ideally, to the responses envisaged by the responsible authorities. Media may, however, give also a negative twist when reporting on the rulings of the ECtHR. By way of an example media response following such judgments as Lavents v. Latvia and Bazjaks v. Latvia have to be mentioned. It did not focus on the essence of the violations established, but rather contributed towards the overall public dissatisfaction with the fact that persons who have done "bad things" at home have been acknowledged as victims in Strasbourg.

In the case Lavents $v$. Latvia the applicant was convicted for leading the largest private bank to bankruptcy, leaving thousands of angry Latvian residents without their savings. ${ }^{147}$ This was only the second judgment were violation against Latvia was established and it brought considerable frustration in the public towards the ECtHR without a clear understanding of the exact competence

\footnotetext{
145 http://at.gov.Iv/lv/judikatura/ect-nolemumi/.

146 Interview with Anhelita Kamenska, Director of the Latvian Centre for Human Rights, 25 September 2013.

147 See chapter 3.2.2 below.
} 
and tasks of the ECtHR. In the case Bazjaks v. Latvia ${ }^{148}$ the applicant was convicted in Latvia for raping a 15 years old girl. The ECtHR found a violation of Article 3 (and Article 13) of the ECHR on account of poor prison conditions and awarded compensation of 11700 EUR for non-pecuniary damages. Again, the outcome of the case raised laud dissatisfaction in a large part of the public without a focus on the real cause for a violation established and this was fuelled by the media.

On the one hand, these cases illustrated the important role that the media must play in explaining reasons for the established violations and its responsibility for failing to do so. On the other hand, these cases pointed out that a large segment of the population refused to accept that human dignity of all persons has to be respected irrespective of what they have done. Notably, such views were shared by many legal practitioners as well. It can be argued that such disrespect towards human dignity today has been influenced by the denial of individuality under the Socialist era.

\section{The European Court's case law in relation to the state}

\subsection{Overview}

By 1 November 2013 the ECtHR has delivered 78 judgments against Latvia. If the judgments where violations were not found, or which were referred to the Grand Chamber or where decision on the merits was not taken are excluded, 58 judgments remain where at least one violation by Latvia has been established.

Since a judgment may contain conclusions about existence or non-existence of several violations, it has been counted for the purposes of this research that in total the ECtHR has established 110 violations, while at least on 32 occasions a violation has not been found. As it can be seen from the Table 1, the highest number of violations is related to Article 5 (right to liberty and security of a person), Article 3 (prohibition of torture), Article 6 (right to fair trial) and Article 8 (right to private and family life).

Table 1. Violations established by the ECtHR in relation to Latvia

\begin{tabular}{|l|l|l|l|l|l|l|l|l|l|l|l|l|l|l|}
\hline $\begin{array}{l}\text { ECHR } \\
\text { Article }\end{array}$ & 2 & 3 & 5 & 6 & 8 & 9 & 10 & 13 & 14 & 34 & $\begin{array}{l}\text { P1- } \\
1\end{array}$ & $\begin{array}{l}\text { P1- } \\
3\end{array}$ & $\begin{array}{l}\text { P7- } \\
2\end{array}$ & $\begin{array}{l}\text { In } \\
\text { Total }\end{array}$ \\
\hline Violations & 2 & 20 & 35 & 20 & 14 & 2 & 3 & 2 & 1 & 6 & 1 & 2 & 1 & 110 \\
\hline
\end{tabular}

If the violations are viewed from a perspective of their character, i.e., to which sphere of law they are primarily attributable, then the absolute majority of violations - 90 can be attributed to criminal law provisions under the ECHR. It must be noted, however, that "criminal law" is used here as a broad term covering not only those violations that were directly committed in the course of domestic criminal proceedings, but also such violations that under domestic law would fall within a scope of administrative procedure law, while being associated with criminal law. Such examples include improper conditions in the places of detention under Article 3, disproportionate restrictions on the rights to visits and correspondence of detained or imprisoned persons under Articles 8 and 34 of the ECHR and alike.

For the sake of clarity, all violations will be presented by arranging them into four large groups with examination of one case characterising each group.

148 Bazjaks v. Latvia, Application No. 71572/01, Judgment of the ECtHR, 19 October 2010. 


\subsection{Selected examples}

\subsubsection{Life and torture}

There are two violations established under Article 2 (procedural and substantive aspect) and 20 violations under Article 3 . Article 3 violations can be divided into problems related to efficient investigation (7) and to inhuman and degrading treatment and punishment (13). All latter violations, except in one case, are related to conditions in places of detention, including the regime of punishment, diet or lack of adequate medical treatment. Only on one occasion ill-treatment by the police was established. However, the above mentioned 7 violations concerning the lack of efficient investigation signalise that the problem of ill-treatment is much more serious, but it has not been possible to establish whether it had happened.

The case of Jasinskis v. Latvia ${ }^{149}$ stands out among others since it is the only case concerning right to life and because of the serious nature of the problems revealed. A young deaf and mute person, having used alcohol and after a quarrel, fell down the stairs outside a party place. For the purposes of sobering, the police brought this person to a police station without, however, waiting for the ambulance to arrive and check the state of the health. Having spent more than 14 hours in the police station and not being conscious, the person was brought to the hospital where he soon died due to the head injuries suffered from the fall. Investigations against police officers on duty were discontinued three times until they were passed to the outside investigation by the Bureau of Internal Security of the State Police. However, this investigation was also discontinued due to lack of a crime.

The ECtHR found both substantive and procedural violations of Article 2. The police had failed to safeguard the life of the person by not providing adequate medical treatment, including denial of a means of communication to a deaf and mute person. The investigation carried out by the same police entity lacked the minimum guarantees of independence, nor was it expedient, since three times it was referred back by the prosecutor's office due to being inadequate. Likewise the investigation carried out by the external Bureau of Internal Security of the State Police was not prompt and it did not extend to assessment of all important aspects of the case. In sum, the investigation was neither efficient nor prompt and it pointed out significant shortcomings in the work of all involved institutions. The ECtHR awarded EUR 50000 as a moral compensation.

Thus, apart from a lack of respect towards the health and life of a (deaf and mute) person, this case illustrates serious shortcomings in the investigation mechanisms that did not allow establishing the responsibility of the involved law enforcement personnel.

\subsubsection{Liberty and fair trial}

Altogether there were 35 violations of Article 5 established: Article $5(1)-12$ violations, $5(3)-12,5(4)$ -11. Most of the violations under Article 5(1) were related to criminal proceedings and on 7 occasions there was one and the same problem of a lack of legal basis for continued detention while the person in detention on remand gets acquainted with files of the case. Problems under Article 5(3) and 5(4) were related to the lack of proper reasoning, the need and the length of pre-trial detention to the extent that the ECtHR made a statement in the case Estrikh v. Latvia that this "disclose[s] a systemic problem in relation to the apparently indiscriminate application of detention as a preventive measure in Latvia". ${ }^{150}$

It has to be noted that on three occasions violation of Article 5(1) was established in the context of legally incapacitated person's internment in special institutions. The problems included lack of procedures providing sufficient guarantees against possible arbitrary continued hospitalisation and lack of appeal procedures. In the case Mihailovs v. Latvia, ${ }^{151}$ apart from finding a violation of Article

\footnotetext{
${ }_{149}$ Jasinskis v. Latvia, Application No. 45744/08, Judgment of the ECtHR, 21 December 2010.

150 Estrikh v. Latvia, Application No. 73819/01, Judgment of the ECtHR, 18 January 2007, para. 127.
} 
5(1) on account of a lack of medical opinion justifying detention and its regular re-assessment, a violation of Article 5(4) was found because the law did not provide for automatic judicial review of the lawfulness of placing and keeping the person in a social care institution. This and other two cases point out serious problems in relation to safeguards against arbitrary isolation of individuals from the public sphere.

Article 6 was found violated on 20 occasions: Article 6(1) - 18 violations, Article 6(2) -2 . Of these 20 violations 14 were related to criminal procedure, 5 to civil procedure and 1 to administrative procedure. In the field of criminal law most of the violations (8) concerned length of proceedings. In the field of civil law the problems were related to access to courts (2), proceedings held in absentia (2) and length of proceedings (1). Proceedings in absentia were also the cause for a violation in the only administrative proceedings case (conducted by civil and not administrative courts). A violation of Article 2 of Protocol No.7 has to be mentioned as well. It was related to inability to appeal against decision of a court of the first and final instance imposing sanctions under Administrative Violations Code - minor violations that fell short of criminal responsibility and were classified as administrative violations in the Latvian legal system, but were considered as "criminal" within the meaning of the ECHR.

Absolute majority of the violations under Articles 5 and 6 occurred in the context of criminal proceedings and were related the Criminal Procedure Code inherited from the Soviet legal system. The case Lavents v. Latvia ${ }^{152}$ serves as a good illustration. The applicant was the head of the largest bank in Latvia in mid nineties. In 1997 the court of first instance started consideration of the case and in 2001 the applicant was sentenced to 9 years in prison for five crimes mostly connected to banking and economic activities, as a result of which thousands of Latvian residents lost their investments amounting to 227000000 EUR. The ECtHR established violations of Articles 5, 6 and 8 on seven accounts and awarded 15000 EUR for costs and expenses, but did not award compensation for nonpecuniary damages.

Article 5(3) was violated because of the lack of due diligence on a part of the judicial authorities (4 years and 6 months) and insufficient reasons for continuous detention on remand. Article 5(4) was violated because the court lacked the required elements of independence and impartiality. Article $6(1)$ entailed three separate violations. First, due to unprecedented resignation by one of the two lay judges, the court could not continue examination of the case in the same setting - this was found to be contrary to domestic law and therefore the court panel could not be considered as "established in accordance with law". Second, in interviews to two newspapers the presiding judge had admitted that the applicant would be either fully or partially found guilty and advised the defence to prove his innocence. This was found to be incompatible with the requirement of impartiality of the court. Third, the trial did not take place within a reasonable time. Irrespective of the complexity of the case that in principle could justify the overall duration of 4 years and 6 moths, the violation was caused in particular by 11 months of inactivity following the resignation of the court panel. The statements made by the presiding judge concerning the guilt of the accused person amounted to violation of the presumption of innocence under Article 6(2). Finally, the domestic legal provisions lacked the required precision for the control of correspondence to be "in accordance with the law" and the stringent restrictions on visits by family members during detention on remand set in the by-laws without a possibility of their flexible application both were not "necessary in democratic society" under Article 8(2) of the ECHR.

This was the first case dealing with criminal law provisions that was decided in respect to Latvia. It clearly showed that the letter and spirit of the criminal procedure legislation adopted back in 1961, although amended numerous times, could not live up to the demands of the ECHR standards ten years after the restoration of country's independence. Apart from the fundamental problems of continuous detention and the lack of sufficient motivation, the complicated procedural rules

151 Mihailovs v. Latvia, Application No. 35939/10, Judgment of the ECtHR, 22 January 2013.

152 Lavents v. Latvia, Application No. 58442/00, Judgment of the ECtHR, 28 November 2002. 
contributing towards the overall length of proceedings, prevention of arbitrariness concerning control of correspondence and disallowing proportionality considerations in relation to visits by family members, this case also highlights a broader problem of proper understanding of impartiality and independence and, henceforth, the role of judiciary in a democratic state.

This was the first widely known case when a judge expressed her opinion on the guilt of the accused person. Moreover, a court panel resigned following a joint statement by the Prime Minister and the Minister of Justice published in the Official Gazette where they declared that the decision of a judge to replace detention on remand with a house arrest was contrary to the public interests and expressed the need for review of the existing disciplinary punishments for judges. ${ }^{153}$ Arguably, such actions could be explained by the relatively short experience of independent judiciary.

Without any doubt, the case Lavents $v$. Latvia and other similar judgements made a strong influence on the new Criminal Procedure Law that replaced the old law. Similarly, they shaped understanding of the fundamental principles underlying criminal procedure from a perspective of human rights.

\subsubsection{Privacy, religion and expression}

There were 14 violations of Article 8 established by the ECtHR. The absolute majority of these violations (10) were related to penitentiary system: unjustified control of correspondence on 7 occasions and disproportionate ban on visits on 3 occasions that pointed out deficiencies in the legal regulation as already seen in the case Lavents $v$. Latvia. Two of the remaining "civil rights" cases dealt with expulsion from the country and one each with the right to private life in the context of publication of one's image and with transborder "child abduction" dispute. In the latter case $X v$. Latvia a violation was found on account of reliance on the Hague Convention to determine the place where the child has to stay without sufficient weight given to the best interests of a child. ${ }^{154}$

Article 9 was violated on two occasions - unjustified interference by a public authority into a dispute within religious organisation and denial of entry into the country to a minister without appropriate legal basis for doing so. Article 10 was violated on 3 occasions and these three cases are further examined in the context of a broader impact of ECHR on civil rights. ${ }^{155}$

Several judgements under Article 8 have pointed to the importance of the broader framework of international law and relevance of the historical aspects when deciding on violations of ECHR. These cases concern expulsion of persons who had lost their rights to reside in the country in the context of restoration of Latvia's independence. Altogether there were 4 such judgments: three cases resulted in not finding a violation by the Grand Chamber, but in one case the Grand Chamber found a violation.

The violation of Article 8 was established in the case Slivenko v. Latvia ${ }^{156}$ and 10000 EUR were awarded for non-pecuniary damage. Mrs. Slivenko was married to a military officer of the USSR army and their daughter was born in Latvia. After restoration of Latvia's independence, Mrs. Slivenko and her daughter were registered as ex-USSR citizens, but they were requested to leave Latvia as family members of a military officer in accordance with the bilateral agreement concluded between Latvia and Russia. The majority in the Grand Chamber (11 to 6) noted that the interests of national security carried less weight with respect to the retired military officers and their family members than in the case of active officers. The applicants were found sufficiently integrated into Latvian society since they had spent their lives there and had developed personal, social and economic ties in Latvia. Therefore, Latvian authorities had exceeded their margin of appreciation in striking a balance

\footnotetext{
153 Ibid., para. 20.

${ }^{154}$ X v. Latvia, Application No. 27853/09, Judgment of the ECtHR, 13 December 2011. On 26 November 2013

the Grand Chamber upheld the ruling finding a violation of Article 8 (9 votes to 8 ).

155 See chapter 7.4 below.

156 Slivenko v. Latvia, Application No. 48321/99, Judgment of the ECtHR, 9 October 2003.
} 
between the legitimate aim of protecting the national security and the applicants' rights to private life and home under Article 8.

The dissenting judges emphasised the specific historical context and the purpose of the bilateral treaty - elimination of the consequences of the Soviet rule in Latvia. Since the bilateral agreement pursued legitimate aim - repatriation of the totality of a foreign army, the dissenting judges could not agree that more importance should be attached to the interests of family members of recently retired officers than those of serving officers. ${ }^{157}$ Apart from that, this case raises a question of the special character of multilateral human rights treaties within a general framework of international law and it has been discussed by the International Commission of Jurists in the study on fragmentation of international law. ${ }^{158}$

Interestingly, in all three other related cases violation of Article 8 was initially established by a Chamber, but these cases ended without finding a violation by a Grand Chamber. The Latvian Government proposed to regularise residence status of the applicants to the extent they would not be deported, thus removing the cause for concern. For example, in the case Sisojeva and Others $v$. Latvia $^{159}$ concerning family members of the retired military officer who was not subject to the Latvian-Russian bilateral treaty, the Grand Chamber noted that the ECHR does not guarantee right to specific type of residence permit. Since Mrs. Sisojeva could obtain status of a stateless person and the daughter and a husband could obtain residence permits independently of the first applicant, but they failed to take any action, the Latvian authorities had provided adequate remedy and the case was considered "resolved" and it was struck out of the list. In the case Kolosovskiy v. Latvia ${ }^{160}$ the ECtHR declared inadmissible a complaint about refusal to regularise his stay in Latvia from a demobilised officer of the Soviet army, emphasising the strong links that the applicant had with the army.

By way of a summary, the case Slivenko v. Latvia stands out alone where the violation of Article 8 was established in the context of expulsion of persons with military links. This and the other discussed cases illustrate complexity of the situation for persons who had entered Latvia in the Soviet era and did not qualify for a status that would grant them permanent residence in Latvia and complexity of the questions that required detailed exploration by the ECtHR. In view of the outcomes in these cases, it could be argued that the more importance the ECtHR attributed to the historical context that has led to present-day situations, as well as to broader international law framework, the wider margin of appreciation was attributed to the Government to deal with them.

\subsubsection{Property and elections}

Protocol No. 1 to ECHR has generated very few violations in the Latvian cases, however, all these cases present interesting aspects. There has been one violation established under Article 1 to Protocol No. 1 (and one violation of Article 14 in conjunction with Article 1 of Protocol No. 1 discussed in chapter 7.2. below). In the case Vistinš and Perepjolkins v. Latvia ${ }^{161}$ the problem was in the amount of compensations received for the expropriated property that on one occasion was even 350 times lower than the market value of the property.

Two violations were established under Article 3 of Protocol 1 concerning the right to stand as a candidate in Parliamentary elections. These cases merit particular attention and one of them is discussed in the context of lustration measures (as well as another case - Ždanoka v. Latvia - where

\footnotetext{
157 Joint Dissenting Opinion of Judges Wildhaber, Ress, Sir Nicolas Bratza, Cabral Barreto, Greve and Maruste, para. 4 and 7.

158 Fragmentation of International Law: Difficulties Arising from the Diversification and Expansion of International Law, Report of the Study Group of the International Law Commission finalized by Martti Koskenniemi, A/CN.4/L.682, 13 April 2006, para. 246-248, available from database of the International Law Commission at: http://legal.un.org/ilc/guide/1_9.htm.

${ }^{159}$ Sisojeva and Others v. Latvia, Application No. 60654/00, Judgment of the ECtHR, 15 January 2007.

160 Kolosovskiy v. Latvia, Application No. 50183/99, Decision of the ECtHR, 29 January 2004.

161 Vistiňš and Perepjolkins v. Latvia, Application No. 71243/01, Judgment of the ECtHR, 25 October 2012.
} 
the violation was not found). ${ }^{162}$ The case Podkolzina v. Latvia ${ }^{163}$ concerned language restrictions for persons who wished to run for Parliamentary elections and will be discussed in detail.

Mrs. Podkolzina, as a member of Russian speaking community, was required by law to produce a certificate confirming her knowledge of the state language - Latvian. Despite the fact that the applicant produced duly obtained certificate, the language inspectorate, entitled to supervise compliance with the rules on the state language, requested her to undertake repeated language examination. Since the applicant refused, she was struck off the list of candidates for elections.

The ECtHR established a violation of Article 3 of Protocol No. 1 and awarded 7500 EUR as a compensation for non-pecuniary damages. The ECtHR noted that the requirement itself to have sufficient knowledge of the state language, in view of each country's historical and political considerations, pursued a legitimate am of ensuring that state's institutional system functions properly. However, the procedure to which the applicant was subjected did not comply with the requirements of fairness and legal certainty. There was no legal regulation of the procedure of repeated examinations and, as carried out, it depended on the approach of the respective language inspector, whereas the initial language examination was carried out by a panel of examiners and it was subject to legal regulation. The domestic court that dealt with the complaint afterwards did not consider other relevant aspects, including the fact of the initial examination. Therefore, the decision to remove the applicant from the list of candidates to Parliamentary elections was not proportionate to the above legitimate aim.

This case leads to several conclusions. First, it underlined the need for a proper regulation of the administrative procedure on the level of the Parliament. At the time of the events it was regulated on the level of by-laws issued by the Government and the whole sphere of relationships between individual and a state was terra incognita for the public administration if looked from a perspective of democracy where the executive power is subject to rule of law. This and other fundamental principles the post-Socialist societies started to learn relatively recently.

Second, Podkolzina case also showed that the domestic courts were not equipped to deal with administrative procedure cases. Such cases were reviewed by civil judges who were not sufficiently trained in public law matters. Administrative courts with specially trained judges were introduced with the entry into force of the Administrative Procedure Law.

Third, the Administrative Procedure Law entered into force on 1 February 2004. The adoption of this law was one of the recommendations made by the Ministry of Justice as part of compatibility review carried out prior to ratification of the ECHR. ${ }^{164}$ Thus, the need for such law was obvious and this recommendation was implemented, but it took place almost 7 years after the ECHR became binding on Latvia.

\section{The European Court's case law's effects at a national law}

\subsection{Legislative level}

According to Gunārs Kusiňš, Head of the Legal Office of the Parliament, it is the Ministry of Justice whose primary responsibility it is to assess the need for legislative amendments as a follow up to rulings of the ECtHR. ${ }^{165}$ This means that such legislative initiative would come before the Parliament in the form of a draft law initiated by the Ministry of Justice. However, it also could be submitted by the Members of the Parliament as a proposal for amendment to draft law that has already been submitted to the Parliament and considered in the first or the second reading.

\footnotetext{
162 See chapter 7.1 below.

163 Podkolzina v. Latvia, Application No. 46726/99, Judgment of the ECtHR, 9 April 2002.

164 Letter of the Minister of Justice to the Committee on Human Rights and Public Affairs of the Parliament No. 4-3, 7 May 1997, unpublished.

165 Interview with Gunārs Kusiňš, Head of the Legal Office of the Parliament, 7 October 2013.
} 
It is not frequently when judgments delivered by the ECtHR is the sole reason for amendments in the laws. At the same time, it is difficult to measure the overall impact of the case law of the ECtHR on legislation since it may occur, for example, already at the stage of a permanent or ad hoc working group established for drafting specific law, or later during the discussions in the Legal Committee of the Parliament.

Apart from the area of criminal procedure, an example of a direct influence is amendments to the Parliamentary Elections Law following judgment in the case Ädamsons v. Latvia. In this case the ECtHR established a violation of passive voting rights under Article 3 of Protocol No.1 for the former KGB officer pointing out, inter alia, that the concept of "KGB officer" in the law was very broad. ${ }^{166}$ This concept was narrowed down in the law excluding from restrictions those persons who were involved only in planning, finance and maintenance structures of the KGB.

It is also possible to identify amendments in the laws that were triggered by case law of the ECtHR involving other member states than Latvia. Such example is the judgment in the case Shtukaturov $v$. Russia where the ECtHR found a violation of Article 8 of the ECHR because the law distinguished only between full capacity or full incapacity of mentally ill persons without allowing for boarderline situations. ${ }^{167}$ The Latvian Constitutional Court primarily relied on this judgment when it declared the relevant provisions of the Civil Law in violation of Article 96 of the Constitution. ${ }^{168}$ Afterwards Article 8 of the ECHR and judgment in the case Shtukaturov $v$. Russia were indicated in the annotation among the main reasons for amendments to the Civil Law. ${ }^{169}$

To summarise, there have not been studies carried out assessing the impact of case law of the ECtHR on the Latvian legislation. There can be examples identified of the amendments as a direct result of rulings of the ECtHR in cases against Latvia and against other countries. However, it is not possible to assess the overall extent of the impact.

\subsection{Judiciary}

Latvian courts have accepted that they are bound by case law of the ECtHR and not only in cases involving Latvia. The Latvian Constitutional Court has made a crucial contribution towards this recognition despite the fact that it did not present the most convincing reasons. In a landmark decision in $\mathbf{2 0 0 0}$ the Latvian Constitutional Court made the following pronouncement:

"The case law of the European Court of Human Rights, which in accordance with obligations that Latvia has undertaken (Article 4 of the Law on the European Convention for the Protection of Human Rights and Fundamental Freedoms of 4 November 1950 and its Protocols No.1, 2, 4, 7 and 11), is mandatory with respect to interpretation of the norms of the Convention. This case law has to be used also when interpreting the respective norms of the Constitution." 170

As it was already noted, the object and purpose of declarations made in the Ratification Law was to recognise the competence of the ECtHR (and the Commission) to receive complaints against Latvia for a period of three years. ${ }^{171}$ Its intention was not to recognise judgments delivered against other countries as legally binding. ${ }^{172}$ However, the general character of the pronouncement, the fact the

\footnotetext{
166 See discussion of the case Ādamsons v. Latvia in chapter 7.1 below.

167 Shtukaturov v. Russia, Application No. 44009/05, Judgment of the ECtHR, 27 March 2008.

168 Judgment of the Constitutional Court No. 2010-38-01, 27 December 2010., para. 12.

169 Likumprojekta "Grozījumi Civillikumā" sākotnējās ietekmes novērtējuma ziṇojums (anotācija) [Report of the Initial Impact Assessment (Annotation) to Draft Law "Amedments to Civil Law"], part I, point 2, available from database of the Government at: www.mk.gov.lv.

170 Judgment of the Constitutional Court No. 2000-03-01, 30 August 2000, para. 5.

${ }^{171}$ See chapter 2.2.2 above.

172 Article 4 of the Ratification Law reads:

"In accordance with Article 46 of the Convention the Republic of Latvia three years after depositing of the instrument of ratification and on the basis of mutual agreement among the High Contracting Parties recognises as compulsory ipso facto without special agreement the jurisdiction of the European Court of Human Rights in all matters concerning interpretation and application of this Convention and its protocols (including Articles 1-4 of Protocol No.4 and Articles 1-5 of Protocol 
Latvian Constitutional Court in this judgment referred to a number of judgments delivered by the ECtHR against other countries and the further practice of the Latvian Constitutional Court indicated that it treated Article 4 as imposing legal obligation to follow interpretation of the ECHR provided by the ECtHR in case against any country. This statement was echoed by other courts and it essentially removed any discussion in Latvia on the binding character of case law of the ECtHR.

The Latvian courts have accepted the ECHR as a working instrument in their daily work. All three departments of the Supreme Court have explicitly indicated that the ECHR has to be applied by the courts. There are cases from all three-tier courts demonstrating that the ECHR is applied in both ways: as a source of law and as a tool of interpretation of domestic legal provisions, including the Constitution. There are a number of cases where the ECHR has decisively influenced outcome of a case.

A recent study on the ECHR in the Supreme Court showed that there is no uniform methodology how the ECHR is approached. However, it demonstrated certain tendencies: when the ECHR is invoked mostly at the initiative of the parties, treated as a source of law and applied without a reference to case law of the ECtHR, there is a risk of application of the ECHR on the level of its literal reading and, hence, of its violation. Such situation was predominant in criminal cases. To the contrary, when the ECHR is invoked mostly by judges themselves, used to interpret provisions of domestic law with regular references to case law of the ECtHR, the ECHR fulfils a role of a "textbook". This was prevalent in administrative cases. In civil cases the situation was mixed. ${ }^{173}$

The situation described in relation to criminal cases seems to be characteristic to countries of Central and Eastern Europe in general. Another recent study claims that references to ECHR and case law of the ECtHR in particular in courts of the said countries are rare (the higher the court, the rarer are references) and the knowledge among the lawyers of the ECHR system is typically limited to the text of ECHR and may be to a few most widely discussed cases against their own country. ${ }^{174}$ This is understandable in view of the lack of initial education on the ECHR and the language barrier. There is a high risk of violating ECHR if the Supreme Court, being fully aware that it has to apply ECHR, does it on the level of literal reading assuming that its contents are identical to domestic legal provisions. At least, in the case of Latvia there is a strong correlation between the least number of references to case-law by domestic judges and highest number of violations established by the ECtHR in the area of criminal law.

A use of the ECHR as a "textbook" is an exception from the overall picture. The use of the ECHR with the aim of establishing contents of and methodology for application of domestic legal provisions can be widely observed not only in the Administrative Cases Department of the Supreme Court (and administrative courts in general), but first of all in the Latvian Constitutional Court. These courts were established after the restoration of independence and the newly appointed judges had to apply domestic human rights provisions in the area that lacked practice and doctrine. Here the ECHR with the elaborated case law provided a valuable guidance. From this perspective, it can be argued that the role and impact of the ECHR in these courts significantly exceeded what could have been expected from one of the binding international treaties.

This proves existence of completely different dynamics in judiciary towards application of the ECHR. The differences are illustrated also by diametrically opposite philosophies regarding the role of judiciary in law-making with the ECHR as a point of reference. The Administrative Cases Department of the Supreme Court resorted to the doctrine of the ECHR as a "living instrument" developed by the ECtHR and claimed that the same doctrine is applicable to the Constitution - with the aim of

No.7)."

173 Martins Mits Eiropas Cilvēktiesību tiesas judikatūra Latvijas Republikas Augstākās tiesas nolēmumos [Case Law of the European Court of Human Rights in Decisions of the Supreme Court of the Republic of Latvia], Supreme Court of the Republic of Latvia, December 2012, para. 1 - 7 of the Conclusions, available at: http://at.gov.lv/lv/judikatura/tiesu-praksesapkopojumi/citi/.

174 Frank Emmert "Conclusions" in Leonard Hammer, Frank Emmert (Eds.) The European Convention on Human Rights and Fundamental Freedoms in Central and Eastern Europe, Eleven International Publisher: the Netherlands, $2012,600$. 
interpreting the provisions of the Constitution in accordance with the present day needs (in relation to spelling of a personal name). ${ }^{175}$ The Civil Cases Department of the Supreme Court, in its turn, observed that the ECHR does not impose specific obligation, that the Constitution must be interpreted in accordance with provisions of the Civil Law and concluded, with a reference to scholarly writings from 1937, that the courts do not have competence to interpret broadly the relevant concept without express authorisation by the Parliament (in relation to equal treatment of unregistered relationships and registered marriage). ${ }^{176}$

The above philosophies co-exist within one court and they can be assessed at various levels. It could be said that this demonstrates the different degrees of openness of judges towards application of the ECHR - in one case the ECHR serves as an argument for dynamic application of the domestic law while in the other case the fact that the ECHR does not require something serves as an argument for restrictive application of domestic law. It could be said that they represent different schools of thought (or generations) based on different understanding of the fundamental principles of separation of powers, parliamentary sovereignty and judicial law-making. It could also be argued that they accurately reflect the fact that the current legal system in Latvia contains a mixture of elements from legal positivism as it developed within the Socialist law and from Civil law with its comparatively flexible system of general principles of law and emphasis on interpretation of law according to its object and purpose. The latter started penetrating Latvian legal system through the ECHR, legal doctrines of other European countries, primarily Germany, and EU law. The link has been established and it continuously "upgrades" domestic legal system.

\section{Remedies}

There have been three violations of Article 13 established concerning Latvia. Two violations were related to conditions in the place of detention. ${ }^{177}$ In both cases the Government was unable to demonstrate that the existing remedies at the time - complaint to the police carrying out detention, to the prosecutor supervising detention in general, civil complaint to a court based directly on provisions of the Constitution, or any other possible legal avenue would be an effective remedy. The third violation of Article 13 was established in conjunction with Article 8 in the context of restrictions placed on visits by family members of convicted persons. ${ }^{178}$ There were no remedies available in this situation.

All three cases related to a period of time before entry into force of the Administrative Procedure Law in February 2004. From then on, complaints about conditions in places of detention and restrictions on visits would fall within a competence of the administrative courts. The situation concerning conditions in places of detention require more detailed exploration since the law sets high threshold for its applicability.

According to Article 89 of the Administrative Procedure Law, situations like poor prison conditions fall within the concept of "factual action" and hence are subject to jurisdiction of the administrative courts. ${ }^{179}$ It is important that the administrative courts interpret reasonable claims about poor prison conditions which indicate that the "minimum level of severity" in the language of Article 3 of the ECHR might be reached as "substantial infringement of the rights of the private person" in the language of the Administrative Procedure Law. Otherwise such claims would be left without a remedy. It is beyond any doubt that violation of Article 3 is a "substantial infringement" of

\footnotetext{
175 Judgment of the Supreme Court No. SKA-184/2012, 27 April 2012, para. 10.

176 Judgment of the Supreme Court No. SKC-4/2012, 1 February 2012, para. 10-12.2.

177 Kadikis v. Latvia (No. 2), Application No. 62393/00, Judgment of the ECtHR, 4 May 2006 and Bazjaks v. Latvia, Application No. 71572/01, Judgment of the ECtHR, 19 October 2010.

178 Moisejevs v. Latvia, Application No. 64846/01, Judgment of the ECtHR, 15 June 2006.

179 Article 89(1) of the Administrative Procedure Law reads:

“(...) An actual action is also action that, irrespective of intent of an institution, create such actual consequences which result or may result in substantial infringement of the rights of the private person.(...)".
} 
individual's rights and freedoms. The same reasoning applies to a reasonable claim about violation of any article of the ECHR, however, it is not limited exclusively to the ECHR.

Since their establishment the administrative courts have demonstrated that they apply reasonably broad interpretation of the "substantial infringement" clause and the ECHR has played a very important role in this process. Moreover, it is this area where the Administrative Cases Department of the Supreme Court has raised the domestic standard.

In the case No.SKA-120/2012 the applicant complained about prison conditions and requested compensation for non-pecuniary damages. The Prison Administration did not dispute that the conditions were "inhuman and degrading", but denied the right to compensation. The Supreme Court noted that, irrespective of the economic situation in Latvia, the compensation may not be substantially lower than that awarded by the ECtHR, otherwise the person would continue to be a "victim" in the context of Article 34 of the ECHR. The Supreme Court made the following statement:

“(...) Irrespective of the constant case-law of the [ECtHR] regarding what conditions are considered as violating Article 3 of the [ECHR] (...), the constant case-law of the administrative courts as well as the conclusions made by the Committee on Prevention of Torture (...), the state refrains from providing comprehensive solution to the repeatedly established problems. This observation was supported also in this case, when it transpired from the statements made by the representative of [the Prison Administration] that there is a general practice to reject complaints about conditions in places of detention submitted by the imprisoned persons. Therefore, the [Administrative Cases Department] takes the view that, in order the state prevented re-occurrence of similar situations as soon as possible, the preventive function acquires greater weight in determination of the amount of compensation in Latvia." ${ }^{180}$ (Author's translation)

This case calls for several conclusions. First, the Supreme Court implicitly recognized existence of a structural problem concerning conditions of detention and increased the amount of compensation to influence state policy on this matter. Second, this is one of the cases which illustrates the deep influence that the ECHR has had on establishing violations and provision of remedies in the cases of poor prison conditions. Third, this reasoning potentially may have an influence on the case-law of the ECtHR involving similar situations from Latvia, e.g., in the form of increased compensations. Fourth, this certainly is a positive development from a perspective of ECHR system, since the domestic Supreme Court on its own initiative puts a pressure on the Government to solve a (structural) problem domestically.

Availability of effective remedies is one of the key elements for successful operation of the ECHR system. In the post-Socialist context this question acquires particular importance since the reality in the past was completely different from what was pronounced in laws - human rights were treated as declaratory pronouncements without providing enforcement mechanism. Against this background it comes as a surprise that there have been only three violations established under Article 13 involving Latvia. This partially can be explained by the working methods adopted by the ECtHR, but this certainly does not mean that there are no more issues related to availability of effective remedies in Latvia.

To support the above statement, problems related to effective investigation can be referred to. The case Jasinskis v. Latvia under Article 2 and the seven violations under Article 3 illustrated the scale of the problem - the lack of efficient investigation concerning actions of the police and prison wards. ${ }^{181}$ These problems have been brought to the attention because the ECtHR has developed an obligation to carry out efficient investigation as a part of procedural obligations under Articles 2 and 3 and does not consider them within a framework of Article 13. An increased attention to the existence of efficient remedies would be desirable from the point of view of the whole ECHR system.

\footnotetext{
180 Judgment of the Supreme Court No. SKA-120/2012, 11 May 2012, para. 13.

${ }^{181}$ See chapter 3.2.1 above.
} 


\section{Dissemination}

\subsection{Teaching}

On the level of higher education the ECHR certainly is addressed. A review of the publicly available study programmes however shows that it is done as a part of a broader human rights context either of the United Nations standards or EU law. For example, there is a bachelor's level course at the University of Latvia titled "Basic Human Rights Law" where $1 / 4$ classes is devoted specifically to the ECHR. Besides, students of the Law Faculty regularly take part in the international moot court competitions on the ECHR. A master's level course at the Riga Graduate School of Law is fully devoted to the ECHR, it includes a moot court as a part of the course with regular participation of current or former judges (domestic or from the ECtHR) and it is taught in English.

On the level of judicial training very important contribution is made by the Latvian Judicial Training Centre. It offers courses on a regular basis aiming to provide a wide range of training programmes - a basic training, regular updates on case law of the ECtHR and specialised training on specific topics. The ECHR is approached in both ways: as integrated element of the relevant topic of domestic law and as a separate topic. The training is done by the Representative of the Latvian Government, domestic judges, academicians. Importantly, many courses are open to external participants, including sworn advocates and prosecutors. There are also specialised courses offered only for particular target groups, e.g., employees of land registry or orphans courts, notaries, sworn advocates, etc. which include topics on ECHR. On a negative side, the training is optional for judges and there is no law-based system that would provide additional motivation for judges apart from the professional interest.

Special training seminars for particular target groups - Prison Administration, Citizenship and Migration Department, etc. - are carried out by the Representative of the Latvian Government. Training in the form of special courses or seminars organised by NGOs is another channel of dissemination of information that needs to be mentioned. The ECHR plays an important role in these activities.

\subsection{Scholarship}

Legal scholars have made a significant contribution to the overall openness of the Latvian legal system to international law and to the comparatively active use of the ECHR by legal practitioners. The fundament was laid down at the time of ratification of the ECHR in 1997. Discussions on applicability and the place of the international human rights treaties, drafting of the national catalogue of human rights - Chapter 8 "Fundamental Human Rights" to the Constitution and ratification of the ECHR took place at the same time. In its landmark article Egils Levits argued that the ECHR should not only serve as a source for claims of individuals against public authorities and be used as a tool for clarification of contents of the domestic legal provisions, but, notably, also serve as a guideline for determining fundamental values of the society. ${ }^{182}$ The latter is particularly interesting observation in the post-Socialist environment and as, it will be seen, it is possible to identify such impact.

In the second half of 1990ies there were intense academic activities carried out in particular by the newly established Institute of Human Rights of the University of Latvia, Faculty of Law that involved organisation of seminars and conferences on the ECHR with Council of Europe experts, publishing of the Latvian Human Rights Quarterly, including summaries of important judgments of the ECtHR in the Latvian language, and other publication.

\footnotetext{
182 Egils Levits "Eiropas Cilvēktiesību konvencijas piemērošana Latvijas iestādēs un tiesās" [The Application of the European Convention of Human Rights by public authorities and courts in Latvia] in Ineta Ziemele (ed.) Cilvēktiesību istenošana Latvijā: tiesa un administratīvais process [Implementation of Human Rights in Latvia: Judiciary and Administrative Procedure], Latvian Human Rights Institute: Riga, 1998, 60-67.
} 
Therefore, at the time when the ECHR was published, scholars were prepared to take the added value that the ECHR with its elaborated case law could offer in the post-Socialist context for the development of domestic legal doctrine. It can be said that the scholarship in principle has accepted this and nowadays the ECHR and case law of the ECtHR have become regular and natural point of reference in scholarly articles on various legal issues where the ECHR serves as tool for crystallising contents as well as methodology for application of domestic legal provisions. It is a strong authoritative argument and such perception is shared by judges as well.

\subsection{Judiciary}

There are no special summaries of judgments either in the cases against Latvia or other member states prepared for judges. Partial exception is the Supreme Court whose judges receive daily summaries of press reviews, including press releases about judgments of the ECtHR concerning Latvia, prepared by the Communication Department of the Supreme Court.

As it was discussed in chapter 2.3.3 above, the Supreme Court manages database of judgments and selected decisions of the ECtHR involving Latvia as well as limited number of rulings against other countries that are translated into the Latvian language by the Ministry of Foreign Affairs. This is extremely valuable resource not only for judges, but for every stakeholder since this data base is publicly accessible.

Regular meetings between the Latvian judge in the ECtHR and judges of the Constitutional Court and judges of the Supreme Court must be mentioned as well. Importantly, such meetings take place not only in Riga, but also in Strasbourg.

A growing interest about the ECHR can be observed from the part of judiciary and, in particular, the Supreme Court over the few last years. Supreme Court organised a conference on the role of the ECHR in the work of the supreme courts in Latvia, Lithuania Estonia and Poland, held lectures exclusively for the judges of the Supreme Court, commissioned above mentioned study on the application of the ECHR by all three departments of the Supreme Court. In the annual conference of all Latvian judges convened by the Judicial Council in 2012, a separate panel was organized on the ECHR.

Overall, it can be said that the judiciary and the Supreme Court in particular signalises about the interest of entering into dialogue with various stakeholders - the ECtHR, the Representative of the Latvian Government, the media that is traditionally critical towards domestic judges and the academia. This can be seen as a reaction to the criticism that has been raised in the press in the broader context of the efficiency of judiciary (in particular, length of proceedings) and more narrowly - the violations established by the ECtHR.

\subsection{Lawyering}

In view of the fact that NGO sector is still in the process of development as are all mechanisms of democracy, the most efficient way of bringing changes in a particular policy area still could be through outside channels, e.g., through the ECtHR. Some of the important cases have been brought before the ECtHR by NGOs.

The Latvian Human Rights Centre specialising in asylum rights and non-discrimination has brought a case Longa Yonkeu v. Latvia ${ }^{183}$ where violations on two separate accounts of Article 5(1) were established in the context of asylum proceedings. Deficiencies of the legal regulation were identified with respect to detention of a person after the end of the asylum proceedings in the court and concerning detention of a person with a view of deportation. A working group within the Ministry of Interior has been established to work on the legislative amendments.

183 Longa Yonkeu v. Latvia, Application No. 57229/09, Judgment of the ECtHR, 15 November 2011. 
The Latvian Human Rights Committee specialising in protection of minority rights has brought such cases as Podkolzina v. Latvia - violation of Article 3 of Protocol No. 1 concerning striking the applicant off the list of candidates to Parliamentary elections in a deficient procedure, Andrejeva $\mathrm{v}$. Latvia - a violation of Article 1 of Protocol No. 1 concerning social benefits on the basis of nationality, Ždanoka v. Latvia - no violation of Article 3 of Protocol No. 1 concerning denial to stand as a candidate for Parliamentary elections on account of being a member of the Communist Party. ${ }^{184}$

As to sworn advocates, there is a large number of law offices in Latvia that advertise, as part of their specialisation, submission of complaints to the ECtHR. Representation of the applicants before the ECtHR is a mixture of sworn advocates, lawyers, NGO representatives and applicants themselves with proportion of the sworn advocates increasing.

\section{The influence of the case law and the democratisation process}

\subsection{Political pluralism}

There are three cases where legislation aimed at safeguarding fundaments of the recently restored democracy was put at test. All three cases dealt with restrictions on passive voting rights under Article 3 of Protocol 1 to the ECHR. Apart from the knowledge of the state language discussed in the case Podkolzina v. Latvia, ${ }^{185}$ two other cases explored validity of prohibition to stand as a candidate in Parliamentary elections for former members of organisations whose object and purpose was not compatible with the idea of independent Latvia.

In the case Ždanoka v. Latvia ${ }^{186}$ a member of the Latvian Communist Party was disqualified for elections. The law excluded a category of persons - those who actively were involved in the Latvian Communist Party after 13 January 1991 - from standing as candidates for elections. The ECtHR found that the restriction was compatible with the principle of rule of law and general objectives of ECHR since it pursued legitimate aims of protecting state's independence, democratic order and national security. The law was sufficiently detailed and flexible allowing domestic courts to determine whether the criteria were met. While such a prohibition could scarcely be acceptable in wellestablished political system, it was considered acceptable in the specific socio-political context of Latvia where it was needed to protect the new democratic order from the resurgence of the former authoritarian regime. The ECtHR also attached particular importance to the fact that the Latvian Parliament had "periodically" reviewed the prohibition (in 2004) and that the Latvian Constitutional Court had accepted validity of the prohibition in 2000. The ECtHR established that the law and procedures available to the affected individuals could not be considered as arbitrary and it did not find a violation of Article 3 of Protocol No.1. This ruling of the Grand Chamber (13 votes 4) overruled the Chamber's decision that had found a violation. ${ }^{187}$

In the case Ādamsons v. Latvia ${ }^{188}$ the person was not eligible for Parliamentary elections because before the restoration of Latvia's independence he had been an officer of the USSR Boarder Guard Forces under supervision of KGB. Electoral legislation disqualified from electing officers of institutions related to public security or intelligence of the USSR. In view of the Latvia's experience under the Soviet rule, the ECtHR agreed that the prohibition to run for elections pursued legitimate aim of protecting the independence, democratic order, institutional system and national security. However, the concept of "officer" in the law was found very broad. For this reason, unlike in the case Ždanoka $v$. Latvia, it would have been necessary to take case-by-case approach allowing assessment of a conduct by a particular person. There was nothing in the conduct of the applicant suggesting that he had opposed restoration of Latvia's independence. To the contrary - he had taken high public posts,

\footnotetext{
184 On all three cases see chapter 7.1 below.

185 See discussion of of the case Podkolzina v. Latvia in chapter 3.2.4 above.

186 Ždanoka v. Latvia, Application No. 58278/00, Judgment of the ECtHR, 16 March 2006.

187 Ždanoka v. Latvia, Application No. 58278/00, Judgment of the ECtHR, 17 June 2004.

${ }^{188} \bar{A}$ damsons v. Latvia, Application No. 3669/03, Judgment of the ECtHR, 24 June 2008.
} 
including Membership of Parliament before the restriction was introduced. The legal basis for electoral disqualification was initially introduced for a period of 10 years and then prolonged in 2004 for another 10 years without providing reasons. The ECtHR concluded that the prohibition to stand as a candidate for Parliamentary elections in the applicant's case was arbitrary and amounted to violation of Article 3 of Protocol No.1.

Both cases allow making two conclusions. First, domestic law and procedures before courts must allow sufficient degree of individualisation in each case in order proportionality of the restriction could be assessed with respect to each affected individual. The broader the affected category of persons is defined in the law, the more detailed individualisation must be possible before the courts. Second, there is a general obligation to review periodically the need for restrictions imposed with the aim of protecting the new democratic order. The more time has passed, the more compelling reasons are required to justify such restrictions.

A distinction must be made between both cases as well. While there has not been a general review carried out on the level of the Parliament concerning the continued need for restrictions to former members of the Latvian Communist Party, steps have been taken towards assessment of the validity of restrictions concerning former KGB officers. Restrictions for the former KGB officers to take various posts and enjoy certain rights have been laid down in almost 20 laws. The procedure for establishing cooperation with KGB is determined in the Law on Maintenance, Use of Documents of the Former State Security Committee and on Establishing the Fact of Cooperation with KGB (KGB Law) adopted in 1994. Apart form the procedure, Article 17 of the KGB Law provides that cooperation with KGB may be established and used to the detriment of the rights of a person only for a period of 20 years. It was exactly this article that was amended in 2004 extending the time period from 10 years initially set to 20 years without, however, reviewing the need for maintaining each restriction contained in various laws. The Latvian Constitutional Court confirmed validity of the extension in 2005 without undertaking assessment of the validity of each restriction. ${ }^{189}$ The period of 20 years expires in 2014 and there is a draft law submitted to the Parliament envisaging extension of the time period for another 30 years. ${ }^{190}$

The concept of KGB officers in electoral legislation has been narrowed down. Amendments were made to Article 5(5) of the Parliamentary Elections Law specifying that restrictions to stand as a candidate for elections do not apply to the persons who have been employed in the planning, finance and maintenance structures of the KGB. ${ }^{191}$ The procedure for establishing cooperation with $K G B$, though, has remained intact and it does not require individualisation in each particular case. Individualisation would anyway be hampered by the fact that there is a very limited part of KGB archives at the disposal of the Latvian Government while most of the archives are in Moscow where the Latvian authorities have not been granted access.

Lustration process and passive voting rights of persons who have been members of organisations whose aims are not reconcilable with independent and democratic state are socially and politically sensitive matters. Without any doubt, case of Ždanoka $v$. Latvia through not establishing a violation and Ādamsons v. Latvia through narrowing down the range of affected persons have influenced the categories of persons who by law are not eligible to stand for elections. The same holds true for Podkolzina case - it has expressly acknowledged legitimacy of the state language requirements for candidates and such requirements were recently reintroduced. However, Latvia still needs to carry out a careful assessment of the extent of restrictions for the former members of the Latvian

\footnotetext{
189 Judgment of the Constitutional Court No. 2004-13-0106, 22 March 2005.

190 Grozījumi likumā "Par bijušās Valsts drošǐbas komitejas dokumentu saglabāšanu, izmantošanu un personu sadarbības fakta ar VDK konstatēšanu" [Draft Amendments to the Law on Maintenance, Use of Documents of the Former State Security Committee and on Establishing the Fact of Cooperation with KGB], available from the legislative database of the Parliament at: http://titania.saeima.Iv/LIVS11/saeimalivs11.nsf/.

191 Grozījumi Saeimas vēlēšanu likumā [Amedments to the Parliamentary Elections Law] Latvijas Vēstnesis [Official Gazzette] No. 43, 18 March 2009.
} 
Communist Party and KGB. Of course, the above rulings have also made a significant contribution to the internal public debates on the question of lustration.

\subsection{Equality before the law}

There has been only one case involving Latvia where violation of Article 14 (in conjunction with Article 1 of Protocol No.1) was established, but it concerned important question of Latvian citizenship after restoration of state's independence. The problem raised in the case Andrejeva $v$. Latvia $^{192}$ was that employment in the times of the USSRS carried out on the territory of Latvia, but in enterprises subjected to non-Latvian jurisdiction (Moscow and Kiev), was not calculated towards retirement pension for persons who were not Latvian nationals. Ms. Andrejeva had a passport of Latvian "non-citizen" - a special category of persons who were former citizen of the USSR, were permanently residing in Latvia as of 1 January 1991 and did not have citizenship of any other state. The ECtHR established that the applicant would qualify to a full pension except of the criterion of nationality, that there were no qualifying requirements for calculation of pensions during the Soviet era and that it was Latvia that objectively could assume responsibility over social security of Ms. Andrejeva since she had stable legal ties only with this country. Therefore, the ECtHR did not see "reasonable relationship of proportionality" in not counting the relevant periods of employment for the applicant as it would be in the case of a Latvian national and found violation of Article 14 in conjunction with Article 1 of Protocol No.1 (and of Article 6 in relation to court proceedings before the Supreme Court in absence of the applicant).

It has to be noted that Latvian judge Ineta Ziemele delivered partly dissenting opinion ${ }^{193}$ pointing out broader international law framework that the majority allegedly had failed to take into account. Namely, since Latvia was occupied and its territory was controlled by the USSR in contravention to the rules of international law, then Latvia must not be held responsible for the amounts of pensions that were earned on behalf of the wrongdoing state and which stayed with that state, particularly in view of the fact that Latvia guaranteed a minimum pension to all persons. The ECtHR thus allegedly missed an opportunity to clarify application of the ECHR in the context of state continuity following illegal annexation.

A bilateral agreement between the Republic of Latvia and the Russian Federation entered into force in 2011. According to this agreement, persons could request and obtain recalculation of their pensions in the country of their residence for periods of employment in the other country during the Soviet era and 8900 Latvian non-citizens had submitted such requests to the Latvian authorities. ${ }^{194}$ Thus, with respect to persons formerly employed under jurisdiction of current Russian Federation, the problem was solved by means of a bilateral treaty. This solution was in line with the state continuity doctrine strictly followed by the Latvian Government and without any broader impact on the category of non-citizens residing in Latvia.

\subsection{Due process}

It can be said that the ECHR has made a strong impact on due process regulation in the area of criminal procedure law, to a lesser extent - in civil procedure law, as well as it has pointed out inadequacy of the former administrative procedures before the entry into a force of the Administrative Procedure Law in 2004.

The 65 violations established under Articles 5 and 6 of the ECHR ${ }^{195}$ clearly demonstrate inability of the criminal procedure legislation inherited from the Soviet era to provide sufficient due process

\footnotetext{
${ }^{192}$ Andrejeva v. Latvia, Application No. 55707/00, Judgment of the ECtHR, 18 February 2009.

${ }^{193}$ Action Report of the Government of the Republic of Latvia on the execution of the judgment of the European Court of Human Rights in the case Andrejeva v. Latvia, Secretariat of the Committee of Ministers, DH-DD(2013)746, 2 July 2013, available at: https://wcd.coe.int/ViewDoc.jsp?id=2083611.

194 Ibid., para. 21.

195 See chapter 3.2.2 below.
} 
guarantees. It took more than eight years from the moment of ratification of ECHR, when a new Criminal Procedure Law entered into force in 2005. The new law provides much more detailed regulation concerning issues revealed in the judgements against Latvia by the ECtHR - this has been, for example, confirmed by the ECtHR in admissibility decision in the case Dergacovs $v$. Latvia where the complaint was dismissed due to non-exhaustion of the new remedies concerning extension of detention. ${ }^{196}$ Thus, the ECHR standards have been extensively considered when the Criminal Procedure Law was drafted and a position of investigative judge introduced with the aim of securing observance of human rights standards during criminal procedure.

There was a need to introduce new procedures in all areas of law, thus a new Civil Procedure Law entered into force on 1 March 1999 and Administrative Procedure Law - on 1 February 2004. The Criminal Procedure Law entered into force as the last - on 1 November 2005. Like in the area of administrative procedure, adoption of new criminal procedure legislation was recommended by the Ministry of Justice in the context of compatibility review carried out prior to the ratification of the ECHR. ${ }^{197}$ Interestingly, there was no single recommendation made concerning substance of the criminal procedures during compatibility review. While this can be explained by the fact that the work on drafting the new Criminal Procedure Law had already started at the time of the compatibility review, there was a long period of time when adequate Criminal Procedure Law was neither in place nor issues of concern even identified during compatibility review. This points to a problem of due diligence on the part of the state in complying with its obligations under ECHR.

With regard to Administrative Procedure Law, it is interesting to observe that ECHR made an impact there in a form of a methodological approach that has been developed by the ECtHR and transposed into the domestic law. Article 66 of the Administrative Procedure Law deals with proportionality considerations. ${ }^{198}$ The three elements described in Paragraphs 2-4 are very similar to the "traditional" three elements of proportionality principle - suitability, necessity, proportionality sensu stricto - as developed, for example, in German legal doctrine. ${ }^{199}$ The remaining element in Paragraph 1, however, has been explained with a reference to ECHR. Egils Levits, one of the drafters of the Administrative Procedure Law and the former judge of the ECtHR, has pointed out that this element is called "social necessity" which forms part of the assessment of "necessity in democratic society" of restrictions to human rights and that it corresponds to the concept of "pressing social need" developed by the ECtHR. ${ }^{200}$ This means that in the context of domestic administrative procedure, restrictions to human rights must be assessed in the light of detailed proportionality considerations and the concept of pressing social need. From the point of view of the ECHR system this is a positive development, since it mainstreams methodological approaches applied by domestic courts and the ECtHR and potentially may lower risk of different outcomes on the domestic and international levels.

It is also interesting to note that the right to fair trial in domestic judicial proceedings is the most often alleged violation before the Supreme Court. A recent study showed that Article 6 of the ECHR

\footnotetext{
196 Dergacovs v. Latvia, Application No. 417/06, Decision of the ECtHR, 12 April 2011.

197 Letter of the Minister of Justice to the Committee on Human Rights and Public Affairs of the Parliament No. 4-3, 7 May 1997, unpublished.

${ }^{198}$ Article 66(1) of the Administrative Procedure Law reads:

"In considering the usefulness of the issue of, or of the content of an administrative act (...), an institution shall take a decision regarding:

1) the necessity of the administrative act for the attaining of a legal (legitimate) aim;

2) the suitability of the administrative act for the attaining of the relevant aim;

3) the need for the administrative act, that is, whether it is possible to attain such aim by means which are less restrictive of the rights and legal interests of participants in the administrative proceeding; and

4) the conformity of the administrative act, comparing the infringement of the rights of a private person and the benefits for the public interest, as well as taking into account that substantial restriction of the rights of a private person may only be justified by a significant benefit to the public. (...)"

${ }^{199}$ See, e.g., Nicholas Emiliou The Principle of Proportionality in European Law, Kluwer Law International: London, 1996, 2637.

200 Egils Levits "Samērīguma princips publiskajās tiesībās" [Principle of Proportionality in Public Law], Likums un Tiesības [Law and Justice], No. 9, 2000, 268.
} 
by far is the most often invoked article before all three departments of the Supreme Court taken together - it was invoked in 74 decisions out of 170 examined ( $86 \%$ in Criminal Cases Department), Article 3 - in 19 decisions, Article 13 and Article 34 (the right to complain to ECtHR) - in 18 decisions. ${ }^{201}$ These statistics link with a high number of violations of Article 6 established by the EC/tHR - 43,99\% of all violations ever established against all member states (Article $13-8,11 \%$ ). ${ }^{202}$ This shows that, apart from "structural" problems such as length of proceedings, there is a persistent need to pay particular attention to fair trial aspects in the work of domestic judges, including in the training programmes. "Human rights friendly" interpretation of the domestic procedural law can help to avoid, for example, such violations as denial of access to domestic courts as established by the ECtHR two civil cases.

\subsection{Civil rights}

The influence of the ECHR on protection of civil rights can be characterised as indirect - finding its way mostly through domestic courts. On the one hand, judgments delivered against Latvia under Articles 10 and 8 showed deviations in favour of state power when public interests had to balanced against particular interests of individual. On the other hand, the ECHR filled in gaps in the domestic legislation providing working tools for the domestic judges in the area of freedom of expression and it gave a firm guidance for judges in deciding on sensitive questions for the public at large in the area of freedom of association.

The three judgements delivered against Latvia under Article 10 are good examples of attaching disproportionately great weight to the interests of the state power. Cases Vides Aizsardzības Klubs v. Latvia $^{203}$ and A/S Diena and Ozolinš v. Latvia ${ }^{204}$ both dealt with balancing of freedom of expression with the protection of reputation of politicians. In the former case domestic courts established that an environmental NGO had damaged reputation of chairperson of municipality by not being able to produce sufficient evidence of its allegations of unlawful actions. In the latter case the newspaper was ordered to pay compensation to the Minister of Economics for unjustified accusations of abuse of power in the interests of a private company. The third case Nagla v. Latvia ${ }^{205}$ dealt with searches of a journalist's home to secure evidence in criminal investigation against another person without relevant and sufficient reasons, so it concerned balancing of journalist's freedom of expression (including protection of sources) against the interests of criminal investigation.

All three cases demonstrate that domestic courts attributed greater weight to the protection of the interests of politicians and investigation and did not properly consider the role and the weight of the press in a democratic state. It can be argued that the shift towards protection of the interests of public sector (politicians and investigation) resembles the historical influence of the over-protection of the state power in the Soviet era and of the role of individual as being subordinated to the regime.

The same holds true for those nine violations of Article 8 (correspondence and visits) concerning imprisoned persons although from a different angle. These violations demonstrate that, once convicted or even just suspected of committing a crime, the state power may impose restrictions without a need to enter into detailed analysis of their necessity. The more so, once the rules regulating conduct of the imprisoned persons are violated, this may entail harsh consequences. For example, in the case Kornakovs v. Latvia ${ }^{206}$ the prison authority refused to send the applicant's letter to the ECtHR and, when he did so with a help of another person, he received disciplinary sanction - a

\footnotetext{
${ }^{201}$ Martins Mits Eiropas Cilvēktiesību tiesas judikatūra Latvijas Republikas Augstākās tiesas nolēmumos [Case Law of the European Court of Human Rights in Decisions of the Supreme Court of the Republic of Latvia], Supreme Court of the Republic of Latvia, December 2012, para. 11 of the Conclusions, available at: http://at.gov.lv/lv/judikatura/tiesu-praksesapkopojumi/citi/.

202 http://www.echr.coe.int/Documents/Overview_19592012_ENG.pdf, 5.

${ }^{203}$ Vides Aizsardzïbas Klubs v. Latvia, Application No. 57829/00, Judgment of the ECtHR, 27 May 2004.

204 Diena and Ozolinš v. Latvia, Application No. 16657/03, Judgment of the ECtHR, 12 July 2007.

${ }^{205}$ Nagla v. Latvia, Application No. 73469/10, Judgment of the ECtHR, 16 July 2013.

${ }^{206}$ Kornakovs v. Latvia, Application No. 61005/00, Judgment of the ECtHR, 15 June 2006.
} 
reprimand. Altogether there were six violations of Article 34 established by the ECtHR entailing a hindrance of the right of individual petition by the prison authorities.

The rulings of ECtHR have brought the principle of proportionality into the sphere of restrictions imposed on imprisoned persons. In particular, this applies to legal rules on the visits in pre-trial stage and after conviction. The rules regulating checks on correspondence have been changed as well.

The ECHR has not changed legal rules dealing with protection of reputation, however, it has had and continues to have a strong influence on their interpretation and application. The Civil Law regulating protection of reputation, with few amendments, has been re-introduced from 1937. It does not provide for much guidance on the fundamental principles that have to be considered in order to strike a proper balance between the protection of reputation and the freedom of expression. This has forced judges to draw the relevant principles directly from the case law of the ECtHR, although they usually base their decisions on the relevant provision of the domestic law. Interestingly, it was in the above mentioned dispute between the Minister of Economics Strujēvičs and journalist Ozolinš and newspaper Diena where the Civil Cases Department of the Supreme Court made a precedent setting pronouncement:

"When examining the case anew, the court [of appeal] has to take into account that there is a significant difference between the terms "news" and "opinions". It must be examined whether publication of the opinion in the press about the issues of interest to the public could infringe upon the dignity and reputation of Laimonis Strujēvičs as a Minister of Economics (...) by exceeding the limits of the press, and whether it happened in compliance with the standards laid down in Article 10 of the Convention and with the interpretation and application of the said standards by the European Court of Human Rights". ${ }^{207}$

Thus, the lower courts were instructed to apply directly the principles as developed by the ECtHR under Article 10 of the ECHR. Despite the fact that in this particular dispute the domestic courts did not manage to balance the opposing interests properly, domestic courts widely apply the ECHR and the principles developed by the ECtHR in the area of freedom of expression.

Another area where the ECHR has had a strong influence through domestic courts, even in the absence of a judgement finding a violation by Latvia, is freedom of assembly. In a landmark judgment in 2006 the Latvian Constitutional Court substantially revised domestic legislation on convening of events, declaring more that 10 provisions of the domestic law unconstitutional and most of them also contravening the ECHR (and ICCPR). ${ }^{208}$ Further on the ECHR standards have played important role in domestic courts. Traditionally, these would be cases where municipality disallowed an event that is not favourably received by a majority, for example, "pride parade" organised by LGBT community ${ }^{209}$ or to commemorate "de-occupation" of Latvia from the Soviet army on the date coinciding with "occupation" of Latvia by Nazi army. ${ }^{210}$ Despite having to act under strong public and sometimes political pressure, the courts have repealed the bans on processions due to lack of relevant and sufficient reasons and the ECHR standards either expressly or impliedly have provided a firm guidance in taking their decisions.

It could be argued that the strong opposition to events organised by LGBT community by various civic groups, individual religious leaders and politicians as well as the public at large is a manifestation of the majority's unwillingness to accept the right of the particular minority to manifest its diversity however disturbed the majority would feel. Apparently, acceptance of such fundamental rights requires longer experience of democracy. This is exactly in such situations where the value-forming role of the ECHR becomes evident.

Related question, but much more complicated to explore, is the potential influence of the ECHR on formation of values that strengthen rule of law in the context of corrupt practices. According to

\footnotetext{
207 Judgment of the Supreme Court No. SKC-102, 13 February 2003.

208 Judgment of the Constitutional Court No. 2006-03-0106, 23 November 2006.

209 See, for example, Judgment of the Administrative District Court No. A3498-05/19, 22 July 2005.

210 See, for example, Judgment of the Administrative District Court No. A06727-10/17, 29 June 2010. 
Transparency International survey, perception of the corruption level in Latvia by its residents ranked Latvia as No. 54 in the world in 2012, behind the Baltic neighbours (Lithuania - No. 48 and Estonia No. 32). ${ }^{211}$ There have been developments indicating that such perception is not entirely without a reason. For example, in 2007 alleged transcripts of tapped telephone conversations were published between publicly known advocate and his colleagues, judges and other public figures that happened between 1998-2000. The authenticity of the transcripts was never proved, but they pointed to possible discussion by judges of on-going cases outside the court, including with advocates, as well as influence of politicians and businessmen on the judiciary. ${ }^{212}$ In 2007 a Prime Minister had to resign following unconvincing battle and dismissal of a head of the anti-corruption office. In 2011 the people of Latvia voted to dissolve the Parliament - the vote was initiated by the State President following refusal by the Parliament to allow searches in the home of a publicly known businessmen and Member of the Parliament.

There are no judgements delivered by the ECtHR against Latvia that would specifically point out corrupt practices. Nevertheless, the ECHR, as far as it applies, requires existence of and adherence to strict procedural rules on domestic level that prevents arbitrariness. Besides, judgments of the ECtHR crystallise fundamental principles, for example, what practices are not reconcilable with impartiality and independence of a court that contribute to formation of fundamental values. Thus, the ECHR certainly contributes towards prevention of corrupt practices although its impact there is impossible to measure.

\section{The influence in return on the Court's case law}

There have been several cases of importance for the whole ECHR system generated by Latvia. Two cases stand out among the others: Kononovs $v$. Latvia and the above discussed case of Ždanoka $v$. Latvia.

In the case of Kononovs v. Latvia the applicant was convicted in 2004 by the Latvian Supreme Court for war crimes that he committed in 1944. He led a unit of the Soviet partisans that executed 6 villagers and burned alive 3 other persons, including a pregnant women, in their houses as a punishment measure. The applicant claimed violation of Article 7(1) of the ECHR arguing that his acts at the time of commission did not constitute an offence neither under domestic nor international law. The Chamber found a violation of Article 7, but the Grand Chamber, after the case was referred to it by the Latvian government, concluded that there has not been a violation (14 votes to 3 ).

Since the relevant provision of the Latvian criminal law made a reference to international law, the analysis had to be carried on the basis of international law. The ECtHR established, first, that there was sufficiently clear legal basis in international law in 1944 for the war crimes for which the applicant was convicted. Even if the villagers were regarded as non-armed combatants, they were protected from wounding or killing under the customary humanitarian law. Second, although the domestic criminal law provisions were not applicable, the ECtHR did not find evidence that the prosecution for the said war crimes would have become statute barred under the international law. Third, the ECtHR established that the laws and customs of war were regulated in sufficient detail and that the applicant as a commander could have been expected to assess the risks of the relevant actions of the partisan unit and his individual and criminal responsibility. The court also noted that it was legitimate for a state after a change of the regime to bring criminal proceedings against persons who had committed crimes during the former regime subject to the principle of the rule of law and other core principles on which the ECHR system is founded. In sum, the applicant's conviction was based on international law in force in 1944 and the crimes were defined with sufficient precision and foreseeability by the humanitarian law.

\footnotetext{
211 Transparency International, Corruption perception index 2102, available at: http://www.transparency.org/cpi2012/results.

212 US Department of State, 2008 Human Rights Report: Latvia, available at: http://www.state.gov/j/drl/rls/hrrpt/2008/eur/119087.htm.
} 
In its ruling the ECtHR, first, clarified what actions constituted crimes under international law during the WWII and that they were not statute barred. This case builds on the principle of progressive development of criminal law through judicial law-making in the context of Article 7 as confirmed by the cases Korbely v. Hungary ${ }^{213}$ and Streletz, Kessler and Krenz v. Germany. ${ }^{214}$

Second, this judgment further confirmed the principle developed in the case Streletz, Kessler and Krenz v. Germany that it is legitimate for a successor state to bring criminal charges against persons who had committed crimes under a former regime, but only in the light of the principles of the rule of law and those core principles on which the ECHR system is built. It was also clarified that situation in Latvia allowed for application of this principle.

Third, this judgment underlined that criminal responsibility extended to acts that constitute war crimes under international law irrespective on which side the person fought. This principle has not been accepted with ease, in particular when the crimes have been committed in the broader context of fight against such global evil as Nazi regime.215 Overall, this case is of high relevance for the countries whose judiciaries are dealing with similar crimes committed long time ago.

As it was discussed above, the case Ždanoka $v$. Latvia concerned restrictions on passive voting rights for the members of the Communist Party - an organisation that acted against restoration of Latvia's independence. ${ }^{216}$ The Grand Chamber did not find a violation of Article 3 of Protocol No.1, but expressed its readiness to return to the restrictions in view of the developments in the country. First, this case is highly relevant from the point of view of the wide margin of expression that the Government enjoyed in setting restrictions to passive voting rights against the background of the country's "political evolution". Second, since the restriction was aimed at protection of the independence of the state, this case contributes to shaping of the concept of "democracy capable of defending itself" introduced in the case Vogt v. Germany. ${ }^{217}$ Third, notwithstanding the considerably wide margin of appreciation, a strict obligation on the part of the Government was set to keep the restriction under periodic review. Once again, these principles were of high relevance for other countries with similar level of maturity of its democracy.

There are other cases to mention - Podkolzina v. Latvia in relation to the wide margin of appreciation to impose language restrictions on candidates to Parliamentary elections on the one hand, and provision of appropriate procedures against arbitrary application of these restrictions on the other hand; Sisojeva v. Latvia - concerning loss of a victim's status if the risk of deportation has ceased to exist without, however, a right to any specific legal status under domestic law; $X v$. Latvia - with regard to the need to consider the best interests of the child in the context of transborder "child abduction"; J.L. v. Latvia ${ }^{218}$ - in relation to particular obligations to protect prisoners who have cooperated with the police and are exposed to violence in prisons. It is interesting to note that all the mentioned cases, except the last two, concern Latvia's historical aspects. As it was noted by Inga Reine, former Representative of the Latvian Government: "Practically every case that goes to the Court for adjudication features either historical issues, or political issues, or the issue of state continuity. These cases are complex for the Court, it cannot copy and paste from its previous judgments." 219

\footnotetext{
213 Korbely v. Hungary, Application No. 9174/02, Judgment of the ECtHR, 19 September 2009.

214 Streletz, Kessler and Krenz v. Germany, Applications No. 34044/96, 35532/97, 44801/98, Judgment of the ECtHR, 22 March 2001.

215 See Concurring Opinion of Judge Myjer to the Chamber judgment in the case Kononovs v. Latvia.

${ }^{216}$ See chapter 7.1 above.

217 Vogt v. Germany, Application No. 17851/91, Judgment of the ECtHR, 26 September 1995.

218 J.L. v. Latvia, Application No. 23893/06, Judgment of the ECtHR, 17 April 2012.

219 Interview of Inga Reine by Nils Muižnieks on 2 August 2009, cited from Nils Muižnieks "Latvian-Russian Memory Battles at the European Court of Human Rights" in Nils Muižnieks (Ed.) The Geopolitcs of History in Latvian-Russian Relations, Academic Press of the University of Latvia, 2011, 238.
} 


\section{Conclusions}

There existed a number of factors at the time of ratification of the ECHR in 1997 that created legal environment for potentially strong influence of the ECHR in Latvia. They included re-introduction of the Constitution from 1922 allowing domestic application of international treaties and not regulating human rights, ambiguity of the constitutional character of the temporary human rights catalogue of the Constitutional Law adopted in 1991, non-existence of proper domestic constitutional doctrines and involvement of legal scholars advocating active application of international human rights treaties. As a result, the ECHR is a highly authoritative and respected argument when it comes to its effects at the level of legislation or in the work of judiciary. Besides, the fundamental principles it embodies are enlightening for all stakeholders, including those who draft laws and apply them, as well as the beneficiary - the public at large.

The influence of the ECHR on the legislative level can be objectively identified - discussed examples included the Criminal Procedure Law, concept of "pressing social need" in the Administrative Procedure Law, amendments in the Parliamentary Elections Law following Ādamsons v. Latvia case and amendments in Civil Law as a reaction to judgement against another member stateShtukaturov v. Russia. In principle, there exist tools both on the levels of the Parliament and the Government to monitor compliance of draft laws with the ECHR. However, there is also a risk of their narrow application and not attending questions that merit closer analysis. Apart from informal consultations established between the involved ministries, it could be recommended to introduce a mechanism on the governmental level with the aim of regular impact assessment from the rulings of the ECtHR against Latvia and other countries.

The influence on the level of judiciary is strong, but also mixed at the same time. The Constitutional Court extensively used the ECHR to clarify contents and methodology for application of human rights provisions and the domestic provisions then were applied in the same way. The ECHR by far stood out from the ICCPR and other international treaties. It can be argued that the Constitutional Court treated the ECHR as equally important to the Constitution.

The ECHR has been extensively used as a tool for interpretation by the Administrative Cases Department of the Supreme Court. Both courts (the Constitutional Court and administrative courts) were introduced after the restoration of independence. It can be said that they saw and took advantage of the added value that the ECHR and its elaborated case law could offer in the postSocialist context. Hence, the ECHR played a role of a "textbook". This was specific and certainly positive development that allowed very fast learning. Moreover, all courts accepted that they could rely on interpretation of the ECHR as provided by the ECtHR in cases against any member state, not only Latvia. Although this premise was based on a very broad interpretation by the Constitutional Court of the competence of the ECtHR to review complaints against Latvia, legitimacy of the argument has never been disputed. Once again, this contributed to swift development of domestic legal doctrine and must be positively viewed from the ECHR system since it minimises a risk of the domestic and ECtHR's case law separating into different directions. The experience of positively open approach by domestic judges to developing domestic legal doctrine in line with the case law of the ECtHR is something that Latvia can offer to the Western member states.

As a negative consequence to overall acceptance of the obligation to apply the ECHR must be mentioned its application on the level of literal reading. For example, Criminal Law Department of the Supreme Court applied the ECHR almost exclusively as a source of law. On the one hand, it demonstrated that judges felt obliged to address allegations about violation of the ECHR, as a rule, made by applicants. On the other had, the lack of references to case law and treatment of the ECHR provisions together with the domestic legal provisions suggest that judges may have assumed that contents of the ECHR provisions are identical to the domestic legal provisions. Unless verified, such assumption increases a risk of a violation of the ECHR by the Supreme Court despite its express pronouncement to the contrary. 
The ECHR has been used as an argument either to foster or hamper judicial law making by different departments of the Supreme Court. This is a symbolic manifestation of the mixture of legal traditions that are present in Latvia - a dominance of the letter of law characteristic to legal positivism as it was prevalent in the Socialist Law and an emphasis on the spirit of law in accordance with traditions of the modern Civil Law countries. The latter started entering into Latvian legal space through international human rights and the case law of the ECtHR in particular. Law of the European Union came later in time.

The question of the ECHR as a value guideline can be approached from several angles. If judgements delivered by the ECtHR against Latvia are examined from the point of view of what serious deviations from the fundamental values of the ECHR system they attest to, the following problems have to be pointed out: degrading and inhuman conditions in places of detention (Article 3), a general lack of efficient investigation (Articles 2 and 3 ), due procedures to prevent arbitrary placing and keeping persons of unsound mind in special institutions (Article 5(1) and (4)), massive violations of due process guarantees in criminal matters (Articles 5 and 6), disproportionate restrictions on correspondence, in particular punishments for correspondence with the ECtHR (Articles 8 and 34), misbalanced protection of politicians and disregard of the public watchdog role (Article 10). All the mentioned problems except in relation to persons of unsound mind and the politicians are related to criminal law sphere and can be explained by the attitudes prevailing in the Soviet era that persons who have committed crimes do not deserve equal protection. Similarly, indiscriminate placing of persons in special care institutions and over-protection of the representatives of the state power may be explained as consequences of the need to protect the regime in the Socialist era.

A different approach to the question of the value guideline would be to explore which judgments have caused massive dissatisfaction among the public. This is certainly judgment in the case Lavents v. Latvia where thousands of residents had lost their savings in the bank that was led to bankruptcy unwillingness to accept a "victory" by such applicant in the ECtHR could be at least partially explained by the above reasons. The case Bazjaks v. Latvia where the public outcry was caused by the compensation awarded to a person whose detention amounted to inhuman and degrading treatment and who was imprisoned because he had raped 15 years young girl raises a fundamental question of disrespect towards human dignity. It is precisely this concept on which the protection against ill-treatment is based. Alarming is the fact that the general public sentiment is shared by many legal practitioners. Another example is the strong opposition to holding peaceful "pride parades" by LGBT organisations. This primarily demonstrates that the majority is not ready to let minorities to manifest their difference. There are no judgements involving Latvia on this point, however, it is exactly the ECHR that not only provides guidance as to the fundamental principles applicable in such situations, but also serves as a bastion for domestic judges on whose authority their decisions are encored in favour of the freedom of assembly. The same holds true for domestic judges awarding compensations to persons detained in prison conditions falling below standards of Article 3.

If looked at an overall influence from the judgements delivered against Latvia, the ECHR has certainly contributed to democratisation of the country in areas of due process in criminal matters, acknowledging the role of the media in democracy and partially regarding lustration process. Violations only under Articles 5 and 6 account for half of the total number of violations against Latvia (65 out of 110) and as a result a new Criminal Procedure Law adequately addressing the established problems of detention on remand (the need, the reasoning, the length and control), length of proceedings, control of correspondence has been adopted and investigative judges introduced with a mandate of supervising compliance with human rights guarantees. In the area of balancing protection of private life with freedom of expression the influence of ECHR has manifested itself trough massive application of the principles developed by the ECtHR by domestic judges to fill in gaps in the Civil Law. In lustration context the influence is twofold: the legitimacy of restrictions in the context of passive voting rights has been confirmed (Ždanoka v. Latvia) and this has helped to strengthen the institutions of high importance for democracy. On the other hand, a message has 
been sent that the restrictions must be proportionate to a sufficient degree (Ādamsons v. Latvia) and may loose legitimacy after lapse of time. The Parliament still needs to carry out a careful assessment of the extent of such restrictions.

The ECHR is limited in scope and there are important questions related to democratisation that are not directly covered by it, for example, corruption and maturity of public administration. There are also questions that are directly covered, for example, favourable treatment of particular individuals by judges that falls within a scope of independence and impartiality of the court under Article 6 , but have never resulted in legal proceedings either before domestic courts of the ECtHR. It must be observed that Latvia is not an exception in the overall fall-back of the Eastern and Central European countries in mid 2000 evidenced as decline of trust in public institutions, fair politicians and the benefits of democracy as opposed to firm belief in liberal values that dominated during transition from Socialism to democracy. ${ }^{220}$ Although it is impossible to measure to what extent the ECHR has contributed to overcoming corrupt practices and crisis of trust, it is possible to think of the potential influence in two ways: as imposing obligation to strictly follow procedural rules under domestic law to prevent arbitrariness and through manifesting values on which the ECHR is built. In the latter case the effects could be reasonably expected in a longer term and this links with the question of education.

The Latvian cases have made the ECtHR to pay particular attention to historical aspects and consider them in a broader context of international law. Case of Ždanoka v. Latvia has set a standard of a very wide margin of appreciation on passive voting rights against the background of country's political evolution and the need to preserve democracy. Case of Kononovs v. Latvia has raised a question of justice and responsibility for international crimes committed during WWII by the victors'. These are not easy questions for the ECtHR and as it has been pointed out with respect to the Latvian cases by Nils Muižnieks, the current Commissioner for Human Rights of the Council of Europe: "the Court has demonstrated a certain inconsistency in the degree to which it has judged itself or the Government as being better placed to evaluate restrictions imposed in the name national security based on lingering threats from former Communists, military personnel or KGB officials." 221

Overall, the influence of the ECHR in Latvia exceeds far beyond the immediate effects of judgements delivered against the country. The ECHR has made a positive contribution towards democratisation of Latvia in various different forms, such as being a checklist in the process of legislative drafting, a text-book or applicable law by judges, an advocacy tool by NGOs. Of course, there is a room for further expansion. Apart from the suggested monitoring mechanism on the level of the Government, legal summaries about relevant rulings of the ECtHR for different groups of legal practitioners could help in the area of dissemination. Elaborating the system of motivation in the context of judicial training and encouraging specialisation in the ECHR for sworn advocates could be other paths worth of following. Increased focus on the availability of remedies both on the domestic level and from the side of the ECtHR could also contribute to enhanced compliance with the ECHR on domestic level.

Apart from that, perhaps the most important contribution that the ECHR has made towards democratisation is through shaping the values of the society. In order to understand the outcome of a ruling from the ECtHR, it is necessary to understand the principles on which the ruling is based. It is this aspect that sometimes is not duly acknowledged, but it has to be properly addressed on all levels of ECHR application and particularly emphasised in education and professional training.

\footnotetext{
${ }^{220}$ Ivan Krastev "The Strange Death of Liberal Consensus" Journal of Democracy, October 2007, Vol.18, pp. 56-57.

221 Nils Muižnieks "Latvian-Russian Memory Battles at the European Court of Human Rights" in Nils Muižnieks (Ed.) The Geopolitcs of History in Latvian-Russian Relations, Academic Press of the University of Latvia, 2011, 237-238.
} 


\section{LITHUANIA}

Dr Danutė Jočiené*

\section{The European Convention on Human Rights in the Lithuanian legal system:}

The lessons learned and perspectives for future

\section{Introductory Remarks}

The Act of the Re-Establishment of the State of Lithuania of 11 March 1990 emphasized restoration and legal continuity of the State and declared its independence from the dissolving Soviet Union. The same Act declared the willingness of the re-established State to ensure the respect for human and citizens' rights. The process to a new democracy had been followed by many political, societal and legal changes.

The Constitution of the Republic of Lithuania was approved by the citizens in the Referendum on 25 October 1992. It embodied the inborn (natural) character of the rights and freedoms of individuals (Article 18) which is of the crucial importance for the effective human rights protection. The Constitution emphasized the equality of all people before the law, the court and other State institutions (Article 29). The Constitution granted also a right to apply to court in case of the violation of his/her rights (Article 30$)^{222}$.

The re-established State needed some fundamental principles on which the human rights protection system should have been based. Therefore already in 1991 the Supreme Council of the Republic of Lithuania, declaring its allegiance to universally recognized human rights and fundamental freedoms and acknowledging the duty to protect human rights values, pronounced its accession to the documents of the International Bill of Human Rights, declaring that Lithuania was ready ${ }^{223}$ :

- to adhere to the Universal Declaration of Human Rights adopted by the General Assembly of the United Nations Organization on 10 December 1948 and decided:

1. to accede to the following International Bill of Human Rights documents of 16 December 1966:

the International Covenant on Economic, Social and Cultural Rights;

the International Covenant on Civil and Political Rights;

the Optional Protocol to the International Covenant on Civil and Political Rights.

This accession to the Universal human rights documents demonstrated clear intention of the young Lithuanian democracy to respect and promote the fundamental human rights values which had already been set up both at universal and regional levels. Acceptance of Lithuania's membership in the Council of Europe on 14 May 1993 and subsequent ratification of the 1950 Convention for the Protection of Human Rights and Fundamental Freedoms (thereafter - the European Convention on Human Rights or the Convention) and some of its Protocols on 27 April 1995 had clearly demonstrated further efforts of the State to strengthen human rights standards and rule of law within society of Lithuania after the fall of the soviet regime.

222 Constitution of the Republic of Lithuania 1992. Publishing House of the Seimas, 1993. P. 17, 20-21.

223 Supreme Council of the Republic of Lithuania. Resolution on the Accession of the Republic of Lithuania to the documents of the International Bill of Human Rights. 12 March 1991 No. I-1136, Vilnius. http://www3.Irs.It/pls/inter3/dokpaieska.showdoc_l?p_id=382981 
The respect for human rights and the rule of law opened for Lithuania the further possibilities towards the integration into the international alliances: on 29 March 2004 Lithuania joined the NATO Alliance and on 1 May 2004 was accepted as a full member of the European Union.

Now, after 18 years of the application of the European Convention on Human Rights in the Lithuanian legal system, it can be concluded that for Lithuania the Convention became "an extraordinary success story" which has enormously influenced the domestic law and practice.

\section{Historical aspects of the accession of Lithuania to the European Convention on Human Rights}

\subsection{Creation of the Working Group for compatibility studies}

The Republic of Lithuania when applying for membership to the Council of Europe on 14 May 1993 signed the Convention on the same day.

The Convention and its 4, 7, 11 Protocols were ratified 2 years later, on 27 April 1995. The Lithuania's accession to the Convention has been effective since 20 June $1995^{224}$.

Lithuania chose so called "legal" way for the ratification of the Convention - at first, to analyse a real situation at domestic legal order, and only after such analysis to take a decision concerning the ratification of the Convention ${ }^{225}$. Such legal way has clearly proved its effectiveness after eighteen years of the application of the Convention in the Lithuanian legal system which will be demonstrated later on in this Article.

Prior to ratification, a Working group was set in order to analyze the laws of the Republic of Lithuania as regards their compatibility with the requirements of the Convention. The group which consisted from famous Lithuanian law professors, officials and lawyers was led by Vice Chairman of the Seimas of the Republic of Lithuania Mr. J. Bernatonis. The Working group had studied 102 laws in force and 24 draft laws. The Group's task was to identify the problematic areas of the Lithuanian legal order which were in conflict with the Convention requirements and to identify laws which were not in compliance with the provisions of the Convention and the principles established in the Court's case-law. The Group had made concrete proposals for abolishing or amending some Lithuanian laws or adopting new laws in order to comply with the Convention and Court's case-law standards. Such important laws which were prepared during that time can be mentioned, as, i.e., - the Law on the Pre-trial detention which had an extreme importance for the Lithuanian cases in Strasbourg; the Law on Mental Health Care, where the hospitalisation and medical treatment of the mentally-ill people was regulated; aspects which were analysed at length by the Strasbourg Court ${ }^{226}$; the Law on the provisions of Information to the Public 227 , etc.

Many laws were consequently changed in order to achieve their compatibility (i.e., the Law on the Operational activities, new version prepared and adopted; changes in the Criminal Procedure Code providing an obligation to inform promptly an arrested person about the reasons of his arrest; also to grant a right for the accused person or his lawyer to examine the anonymous witnesses against him $^{228}$; furthermore, the Civil Code was also changed in order to grant a right to the acquitted person to claim damages, etc.).

224 Lietuvos Respublikos j̇statymas Nr. I-865 „Dèl Europos žmogaus teisių ir pagrindiniu laisviu apsaugos konvencijos, jos ketvirtojo, septintojo ir vienuoliktojo protokoly ratifikavimo", in: Valstybės žinios, 1995, Nr. 37913, pp. 2-3.

225 Žmogaus teisès ir laisvès. Lietuvos Respublikos j̇statymų ir 1950 m. Europos Žmogaus teisių konvencijos suderinamumo problemos. Lietuvos Respublikos Seimo leidykla. Vilnius, 1995. P. 6.

${ }^{226}$ See on this issue the case D.D. v. Lithuania, No. 13469/06, Judgment of 14 February 2012; see also the case Liuiza v. Lithuania, No. 13472/06, Judgment of 31 July 2012.

227 See on this issue the case Biriuk v. Lithuania, No. 23373/03, Judgment of 25 November 2008. 
The Working group came also to the conclusion that some new laws should be prepared - the Law on Abortion; the Law on Transplantation of the Human Organs, the Law on the Protection of Personal Data229; the Law on the Children rights; the Law on the State Secrets. It should be mentioned that two first laws have not been prepared even yet, after 19 years after the recommendation given by the Working Group.

The most importantly, the Working group after its enormous studies had emphasised that Lithuania is ready to start the ratification process of the European Convention of Human Rights, noting nevertheless that the country is on the need to change or adopt analysed laws to the European standards during the first years coming after the ratification process. Taking into account the fact that first cases will reach the Strasbourg Court after some time only, the Group was of the opinion that there still was sufficient time to make all needed legislative changes. Finally, the Group recommended also to make some reservations when ratifying the Convention ${ }^{230}$ which can be regarded as very important recommendation for the State which had inherited the Soviet legal system.

It should also be noted that before the ratification of the Convention the Constitutional Court gave its legal Opinion on the Conformity of certain provisions of the ECHR and its Protocol No. 4 with the Constitution of Lithuania ${ }^{231}$. The Conclusion of the Constitutional Court emphasising the compatibility of the both legal instruments (the Constitution and the Convention) had opened the legal way for the ratification of the Convention by Lithuania.

\subsection{Status of International Treaties in the Lithuanian legal system. The legal status of the ECHR in the Lithuania}

According to Article $138 \S 3$ of the Constitution of the Republic of Lithuania: "International agreements which are ratified by the Seimas [Parliament] of the Republic of Lithuania shall be the constituent part of the legal system of the Republic of Lithuania".

With respect to the Convention and other ratified international treaties, this constitutional provision implies that upon its ratification and enforcement the Convention will become the constituent part of the legal system of the Republic of Lithuania and shall be applied in the same way as laws of the Republic of Lithuania.

The European Convention on Human Rights as well as other ratified international treaties therefore have the force of law in Lithuania and in case of conflicts with the laws of Lithuania, have priority over the latter ${ }^{232}$.

Nevertheless, it should be mentioned that the Constitution of the Republic of Lithuanian adopted by Referendum of 25 October 1992, changed the general monistic approach to international treaties which had been clearly stated in the previous Law on International Agreements adopted by the Supreme Council on 21 May $1991^{233}$ (The Law "On International Agreements of the Republic of Lithuania” (Official Gazette "Valstybès Žinios" No 16-415, 1991; No 30-915, 1992).

\footnotetext{
${ }^{228}$ See on this issue the case Birutis and Others v. Lithuania, No. 47698/99 and 48115/99, Judgment of 28 March 2002.

${ }^{229}$ On the problematic aspects concerning the protection of Personal data see the case mentioned in the Footnote No. 6.

230 See Footnote No. 22. See also Footnote No. 4. P. 256-257.

${ }^{231}$ Article 105, para. 3 subpara. 3 of the Constitution provides for that the Constitutional Court shall present conclusions concerning the conformity of international agreements of the Republic of Lithuania with the Constitution.

232 Law on Treaties, Article 11 § 2. 1999, no. VIII-1248, Valstybès žinios, 1999, no. 60-1948.

233 Vilenas Vadapalas. Incorporation and Implementation of Human Rights in Lithuania, in: M. Scheinin (ed.), Internmational Human Rights Norms in the Nordic and Baltic Countries, printed in the Netherlands, 1996, pp.
} 
Article 12 of the mentioned Law established that: "International agreements of the Republic of Lithuania shall have the power of law on the territory of the Republic of Lithuania." It was clear at that time that ALL international agreements concluded by the Republic of Lithuania were equated to the domestic laws.

According to $\S 2$ of Article 11 of the new Law on International treaties adopted in 1999 in case of contradiction between the ratified international treaties and laws, the ratified international treaties will have a priority over national laws. Such provision from the perspective of International Treaties Law can be regarded as a very positive provision, however it should be remembered that such provision is applicable only in the case of the conflict of norms. Moreover, such priority is not granted to non-ratified international treaties, the status of which, in the opinion of the Author, has been unreasonably minimalized at domestic level.

Some legal discussions concerning the hierarchy and legal status of the Constitution and the Convention can be heard at domestic level even now. However, from the Constitutional doctrine formulated by the Constitutional Court of Lithuania is quite clear that the Constitution of the Republic of Lithuania has the legal hierarchy/superiority over all other laws or statutes. According to Article 7 of the Constitution - "Any law or other statute which contradicts the Constitution shall be invalid"234. The Convention as well as other international agreements cannot contradict the Constitution of the Republic of Lithuania; otherwise Lithuania would not be able to execute the obligations arising from the International agreements.

In any case, the general conclusion can be drawn that the ratified international treaties are the constituent part of the legal system of the Republic of Lithuania and shall have the same legal force as (shall be applied in the same way) as the Lithuanian laws. In case of contradiction between the ratified international treaties and laws, the ratified international treaties will have a priority over national laws.

As regards non-ratified international treaties they also constitute the constituent part of the Lithuanian legal system, however in the case of conflict of norms the domestic law should prevail over non-ratified international treaties ${ }^{235}$.

\subsection{Conclusion (Opinion) of the Constitutional Court on the conformity of the European Convention on Human rights with the Constitution of Lithuania}

As it was already mentioned, before the ratification of the Convention the President of the Republic of Lithuania Mr. A. Brazauskas appealed to the Constitutional Court for the Conclusion of the Court in an inquiry on the conformity of certain provisions of the ECHR and its Protocol No. 4 with the Constitution of Lithuania. This possibility to control the constitutionality of international treaties within the Lithuanian Constitution is enshrined in Article 105, para. 3, subpara. 3 of the Constitution ${ }^{236}$

111-167. See also the Conclusion of the Constitutional Court of Lithuania of 24 January 1995.

${ }^{234}$ Egidijus Kūris. Constitutional Justice in Lithuania: The First Decade, in: Constitutional Justice and the Rule of Law, Vilnius, the Constitutional Court of the Republic of Lithuania, 2004, p. 39.

235 See more on this issue: Danutè Jočienè, "The European Convention on Human Rights in the Lithuanian Legal System: Lessons Learned and Prospects for the Future" (p. 229-247). Liber Amicorum Luzius Wildhaber. Human Rights - Strasbourg Views. N.P. Engel, Publisher, 2007; see also Footnote No. 12. See also Vilenas Vadapalas. Tarptautine teisé. Vilnius, Eugrimas, 2006. pp. 278-280. See also the Ruling of the Constitutional Court of 17 October 1995.

${ }^{236}$ Article 105, para. 3 subpara. 3 of the Constitution provides for that the Constitutional Court shall present conclusions concerning the conformity of international agreements of the Republic of Lithuania with the Constitution. 
On $24^{\text {th }}$ January 1995 the Constitutional Court ${ }^{237}$ came to the very important conclusion that there is no contradiction between the provisions of the Constitution of Lithuania and the Convention. This Conclusion of the Constitutional Court had created the legal grounds for the ratification of the Convention by Lithuania. As it was noted before, the Convention and its 4, 7, 11 Protocols were ratified by the Republic of Lithuania on 27 April 1995. The Lithuania's accession to the Convention has been effective since 20 June 1995. Lithuania ratified also the First Protocol of the Convention on 7 December 1995 and the accession to it became effective since 24 May $1996^{238}$.

The Constitutional Court in its Conclusion of $24^{\text {th }}$ January 1995 in a very scrupulous way analyzed the relationship between the International and domestic law noting an obligation placed on the State which has ratified the Convention, to implement effectively the provisions of the Convention (or its Protocols) in its domestic order.

In the opinion of the Constitutional Court, "[...] nowadays, the system of so-called parallel adjustment of international and domestic law is perhaps the most widely spread in Europe; it is based on the rule that international treaties are transformed in the legal system of a state (i. e. are incorporated in it). Such way of realization of international agreements, the Convention among them, is established in the Constitution of the Republic of Lithuania. According to the Constitutional Court, the Convention performs the same function as the constitutional guarantees for human rights on the international scale, because the Constitution establishes those guarantees in a state [...]".

Furthermore, the Constitutional Court relying on Article 13 of the Convention noted that:

\title{
"[...] in Article 138 (of the Constitution) it is determined:
}

\begin{abstract}
"International agreements which are ratified by the Seimas of the Republic of Lithuania shall be the constituent part of the legal system of the Republic of Lithuania." With respect to the Convention, this constitutional provision implies that upon its ratification and enforcement the Convention will become the constituent part of the legal system of the Republic of Lithuania and shall be applied in the same way as laws of the Republic of Lithuania. The provisions of the Convention in the system of legal sources of the Republic of Lithuania are equated to the laws under Article 12 of the 21 May 1991 Law "On International Agreements of the Republic of Lithuania" [...].
\end{abstract}

Equal with laws application of the Convention in the domestic law of the Republic of Lithuania and the legal power of its provisions ipso facto does not ensure yet that the provisions of the Convention shall in all cases be effectively applied, because in the first part of Article 7 of the Constitution it is determined: "Any law or other statute which contradicts the Constitution shall be invalid." Although this constitutional provision by itself may not make the international agreement, the Convention in this case, invalid, however it requires the compliance of the provisions of the international agreement with the constitutional provisions, because in contrary case it would be problematic to implement the Convention in the domestic law of the Republic of Lithuania [...]". According to the Constitutional Court, the legal system of the Republic of Lithuania is based on the fact that no law or other legal act as well as international agreements (in this case the Convention) may not contradict the Constitution. In contrary case the Republic of Lithuania would not be able to ensure the legal protection of the rights and freedoms recognized by the Convention [...] Consequently, national

\footnotetext{
237 Lietuvos Respublikos Konstitucinio Teismo išvada "Dèl Europos žmogaus teisių ir pagrindinių laisvių apsaugos konvencijos 4, 5, 9 ir 14 straipsniu ir jos Ketvirtojo Protokolo 2 straipsnio atitikimo Lietuvos Respublikos Konstitucijai" - Valstybès žinios, 1995, No. 9, § 199, pp.22-30. An English text of the Conclusion, in: Rulings and Decisions of the Constitutional Court of the Republic of Lithuania, Vilnius, 1995, Vol. 4. See also http://www.Irkt.It/dokumentai/1995/i5a0124a.htm

${ }^{238}$ When ratifying the First Protocol of the Convention on 7 December 1995, Lithuania changed the Law No. I865 (op. cit. (note 4) recognizing also the individual application right to the Non-governmental organisation and group of individuals under Article 34 of the Convention; those groups had not been given this right at the time of ratification of the Convention on 27/04/1995 ,...because of an administrative oversight...", in: Valstybès žinios, 1996, Nr. 5-112. P. 3. Council of Europe. ETC, No. 5/46/117. P. 1.
} 
authority, while implementing legal protection, must directly apply constitutional norms and realize the provisions of the Convention [...]".

Some important legal conclusions can be drawn:

1. The Convention as well as other international agreements cannot contradict the Constitution of the Republic of Lithuania; otherwise Lithuania would not be able to execute the obligations arising from the International agreements. The supremacy of the Constitution over the Convention has been clearly developed in the doctrine of the Constitutional Court;

2. The Convention as a special international treaty with its unique purpose forms a part of the domestic Lithuanian system and can be applied by courts and other authorities. However, the Constitutional Court did not indicate that the Convention can be applied directly before the courts, denying especially such possibility in criminal cases.

3. The Constitutional Court of Lithuania decided as well to distinguish between the methods/possibilities of the application of the Convention in civil and criminal matters.

In the opinion of the Constitutional Court a direct application of the Convention was allowed in the civil matters, but denied in the criminal cases. With regard to the later (i.e., criminal sphere) the Constitutional Court concluded that a direct application of the Convention in the criminal matters is hardly possible, as the Convention "...does not provide for any ways of realization of these rights in the states that have ratified the Convention, or legal responsibility of offenders, or appropriate procedures and special jurisdiction for judicial institutions of the states.

The rule ubi jus ibi remedium, i. e. when the law provides the right it also provides the remedy, is obviously valid here. Such remedy in the legal system of a state is established by the laws of this state. The Convention sets forth the remedy only for the cases when litigation concerning the protection of human rights [...] becomes the subject-matter of international jurisdiction [...]".

Nevertheless, international agreements, the Convention among them, is differently applied in separate spheres of legal activity. Concrete ways and forms of their application are established by the laws of the Republic of Lithuania. In civil proceedings direct application of international agreements is established as a way of solving the competition between such agreements and the norms of laws of the Republic of Lithuania [...]. However, said way of deciding the competition of norms shall not be applied in criminal proceedings, [...] where criminal laws and laws of criminal procedure of the Republic of Lithuania shall be directly applied, whereas international agreements shall be applicable only in special cases prescribed by the laws [...].

According to the Constitutional Court, human rights determined in the Convention cannot be realized without direct application of domestic law acts. Putting it otherwise, if only direct application of the Convention is recognized, said rights cannot be secured because the Convention itself does not provide for any ways of realization of these rights in the states that have ratified the Convention, or legal responsibility of offenders, or appropriate procedures and special jurisdiction for judicial institutions of the states.

Such interpretation of the Constitutional Court, taking into account the practical developments at national level, in the opinion of the Author, is not any more legally and practically important. The practice of the Lithuanian courts have clearly demonstrated the tendency that the Convention can be and was directly applied in criminal cases as well. Therefore, the Author concludes that such theoretical distinction between two spheres of law was not very much legally founded ${ }^{239}$.

239 See The Decision of 27 December 2004 of the Appeal Court of Lithuania (Reporting judge A. Kruopys) concerning the violation of the applicant's right to challenge his custody on remand, as he had not been afforded a right to consult properly his criminal file; Decision of the Supreme Court of Lithuania of 13 February 2007 (Reporting Judge G. Goda) concerning the direct reliance on Article 7 of the Convention as to the definition of crime; see also the case of the ECHR Giedrikas v. Lithuania, no. 51392/07, Decision as to the 
The Constitutional Court kept silence in 1995 on the application of the Convention in administrative cases. In the Author's opinion, the administrative courts of Lithuania can be regarded as the most positive set of the ordinary courts not only in the application of the Convention, but also in relying directly on the judgments adopted by the Strasbourg Court in the Lithuanian cases ${ }^{240}$. It should also be remembered that the separate system of the administrative courts was created in Lithuania in 1999 with the aim to deal with the disputes arising from administrative legal relations. The newly created administrative courts of Lithuania had been recognised by the Strasbourg Court as effective remedy under Article 13 of the Convention back in 2003 in the decision of Jankauskas v. Lithuania ${ }^{241}$. The Court took note of the recent practice of the Lithuanian administrative courts which had evolved from the year 2000 onwards. [...].

Coming back to the history of the ratification of the Convention by Lithuania in 1995, it should be noted that having inherited the Soviet legal system, Lithuania was obliged to formulate specific reservations under article 57 of the Convention with regard to the guarantees of Article 5 para 3 of the Convention ${ }^{242}$.

The first reservation concerning the prosecutor's right to take a decision to detain in custody any person suspected of having committed a crime was relied on by the Government in the first cases

Admissibility of 14 December 2010, whether the Strasbourg Court rejected the case, as the applicant could not claim any more to be a victim under Article 34 of the Convention as in a decision of 10 June 2009 the Panevezžys Regional Court relied on Article 6.272 of the Civil Code of Lithuania and Article $6 \S 1$ of the European Convention on Human Rights and granted the applicant's claims for lengthy examination of his criminal case in part, which was approved by the Court of Appeal on 14 May 2010. See also the Decision of the Supreme Court of Lithuania No. 2K-P-9/2012 concerning the presumption of innocence (Article $6 \S 2$ ); see also Decisions of the Supreme Court of Lithuania Nos. 2K-661/2012; 2K-176/2012; 2K-7-96/2012 concerning the reasonableness of the length of the criminal proceedings; see also Decisions of the Supreme Court of Lithuania Nos. 2K-530/2012; $2 \mathrm{~K}-647 / 2012$; $2 \mathrm{~K}-262 / 2012$ concerning the fairness of the proceedings (application of the criminal conduct simulation model), etc. See also the Footnote No. 63.

${ }^{240}$ Administrative case No. A(858)-1452/2010, judgment of the Supreme Administrative Court of 29 November 2010, Reporting judge I. Jarukaitis. In this case the administrative court awarded the non-material damage to the person who was deprived of the right to change his gender in Lithuania, taking into account the legal vacuum, as established in the case L. v. Lithuania, where the European Court of Human Rights found a violation of Article 8 of the Convention and obliged Lithuania to adopt the special law on conditions and procedure for the gender re-assignment surgery, which has not been even yet done. Subsequently, following that decision of the Supreme Administrative Court of Lithuania, the Judge in the ECHR, acting in a Single Judge formation (Article 27 of the Convention), on 23 May 2005 rejected the case Stravinske v. Lithuania (No. 40967/11) as inadmissible, as the applicant cannot pretend any more to claim being as a victim under Article 34 of the Convention after receiving an adequate compensation at domestic level. See also - L. v. Lithuania, no.27527/03, ECHR, judgment of 11 September 2007.

241 Jankauskas v. Lithuania (dec.), no. 59304/00, 16 December 2003. See also: Lietuvos Vyriausiasis Administracinis teismas. Lietuvos Vyriausiasis Administracinio teismo 2010-uju metų veiklos apžvalga. 2011. P. 8-9. See also the Internet page - www.lvat.It (Effectiveness of the administrative courts can be seen from their statistics - during the period of 1999-2010 the county administrative courts had examined a total number of 138,558 cases. In 2010, the county administrative courts examined 10,831 cases, and in only 1605 cases the appeals were submitted to the Supreme Administrative Court. This is a positive aspect, which shows the increasing trust in the county courts, as the mentioned number is by one third less than the cases appealed in 2009. Every year the Supreme Administrative Court of Lithuania receives more complaint concerning the alleged violations of the European Convention on Human rights and the European Union law. The Supreme Administrative Court of Lithuania started its functions in 2001 and during that year examined 4131 cases. In 2010 the Court received totally 9353 cases; during the period of its activities between 2001 and 2010, the Supreme Administrative Court of Lithuania had examined 52, 410 cases in total).

242 The first Reservation declared that a person suspected of having committed a crime, may also be detained by a decision of a prosecutor (effective for one year after the Convention came into force in respect of the Republic of Lithuania (until 20 June 1996). Another reservation - soldiers' detention was declared to be justified without a court's/judge's sanction which remains valid until now. 
declared admissible against Lithuania ${ }^{243}$. The first reservation which was valid for one year after the ratification of the Convention by Lithuania was of the real need during this transitional period in order to obtain some time in order to change the provisions of the criminal procedure law according to the Convention requirements.

And, finally, it should positively be stressed that so called legal way of the ratification of the Convention chosen by Lithuania in 1993 (after the deep analysis of the domestic laws and recommendations provided for their legal improvement) and the application of the Convention in $a$ friendly manner with the Constitution have clearly shown its preferences. The European Convention of Human Rights, having a legal status equal to the Lithuanian laws, has become a legal living instrument and practical remedy for protecting of human rights before the Lithuanian courts and other authorities. The Lithuanian legal system has experienced huge number of legal and administrative changes in order to be capable to fulfil the task of the Convention under Article 1 - to secure effectively the requirements of the Convention at domestic level before the national authorities.

Many new laws have been adopted or old laws changed in order to comply with the standards of the Convention as they are developed in the case-law of the European Court of Human Rights.

\section{The European Court's case law in relation to Lithuania (1995-2013)}

\subsection{General Overview}

During the last six months of the year 1995, after the ratification of the Convention by Lithuania on 27 April 1995, only 16 complaints from Lithuania reached the European Commission of Human Rights (abolished in 1998, after the Protocol 11 came into force). During 1996 the European Commission on Human Rights got 41 complaints against Lithuania. During 1997 the Commission got 61 complaints; only one application in 1997 was declared admissible (Juozas Jéčius v. Lithuania, appl. No. 34578/97, decision on the Admissibility of 1 December 1997 and judgment of 31 July 2000) which concerned the question of the legality of the preventive detention in Lithuania ${ }^{244}$, a denied access to a court and the right to have adequate time to prepare for his defence.

For comparison, during the year of 2003 already 442 new applications were lodged against Lithuania. In 2003 the European Court adopted 3 final judgments in the Lithuanian cases and 199 applications were declared inadmissible or struck out of the list of cases ${ }^{245}$.

In 2009 and 2010 approximately the same number of the new applications against Lithuania reached Strasbourg (284 and 286 accordingly). In 2009 - 261 case against Lithuania was attributed to the judicial formation in the Court, and accordingly in 2012 - 373 cases were put before the judicial Court's body ${ }^{246}$.

\footnotetext{
${ }^{243}$ See Jéčius v. Lithuania, No. 34578/97, judgment of 31 July 2000, §§72-87; see also Grauslys v. Lithuania, No. $36743 / 97$, judgment of 10 October 2000, §§ 47-50.

${ }^{244}$ The preventive detention was based on the former provision of Article 50-1 of the Code of Criminal Procedure which permitted detention with a view to preventing the commission of banditry, criminal association and intimidation (based on the negative characteristic of a person concerned without any concrete evidences whether he had committed a crime or not). After the European Court of Human Rights established a violation of Article 5 with regard to applicant's preventive detention, abolished such possibility to detain a person on the basis of his/her negative characteristic or possible but not concrete ability/readiness to commit a crime. See also Mikalauskas v. Malta case, No. 4458/10, Judgment of 23 July 2013. See also the Footnote No. 22.

${ }^{245}$ European Court of Human Rights, Annual Report 2003. Registry of the European Court of Human Rights, Strasbourg, 2004, pp. 142-143.

${ }^{246}$ European Court of Human Rights, Annual Report 2012. Registry of the European Court of Human Rights, Strasbourg, 2013, p. 160.
} 
In 2012 the Court received 413 new applications from Lithuania. If during the years of 2010 and 2011 the Court was able to decide approximately 160 cases pro year, in 2012 this number reached already 713 cases disposed of judiciary. The majority of these cases were declared inadmissible by the Single judge formation (Article 27 of the Convention; Single judge formation in course from 1 June 2010, when the Protocol 14 entered into force) or Three Judges Committee (Article 28 of the Convention).

Totally 703 inadmissible cases were dealt with. In March 2013 Lithuania had a workload of 227 cases pending before a decision body.

Since the Convention entered into force in respect of Lithuania on 20 June 1995 until 31 December 2012, the total amount of 87 judgments (some cases were joined) have been adopted in the cases against Lithuania ${ }^{247}$.

In 68 judgments against Lithuania at least 1 violation had been established. 12 judgments established no violations in cases against Lithuania (see, i.e., Tautkus v. Lithuania, No. 29474/09, judgment of 27 November 2012; Kuolelis, Bartoševičius and Burokevičius v. Lithuania, Nos. 74357/01, 26764/02 and 27434/02, judgment of 19 February 2008; see also Silickiene v. Lithuania, No. 20496/02, judgment of 10 April 2012; etc.).

7 cases in Strasbourg were finished by the friendly settlement/radiation procedure (see, i.e., Siaurusevičius v. Lithuania, No. 5055199, Judgment (Friendly settlement) of 4 December 2003; Kambangu v. Lithuania, No. 59619/00, Judgment (Friendly settlement) of 19 July 2007; see also Trijonis v. Lithuania, No. 2333/02, the judgment (Struck out) of 15 December 2005, etc.).

The total amount of 3931 cases against Lithuania during those years were disposed of judiciary. Single Judge or Three Judges Committee cases amount to 3771 inadmissibility decisions (Information as to September 2013).

Inheriting the Soviet system, Lithuania was struck by the fact that the preventive, lengthy or unjustified detention on remand had not been in line with the requirements of the Convention. As well as the fact that no possibility existed at this time in the Lithuanian law to take the proceedings in order to question the lawfulness of the ordered detention.

Now, after 18 years of the application of the Convention in Lithuania we can be proud that, in principle, the main legal problems related to Article 5 and 6 and identified as very problematic by Strasbourg Court, have disappeared. This was due to the State's efforts to comply with the Convention requirements at domestic level and to change the old soviet legislature and practise.

Secondly, it should be observed that a clear new tendency can be detected from the Lithuanian cases in Strasbourg - they are becoming more legally complicated and much better reasoned by the applicants or their representatives. If the first Lithuanian cases were, in principle, related exceptionally to the detention on remand legality's problems, problems concerning the procedural guarantees under Articles 5 and 6 of the Convention, as well as the length of detention and fair trial problems, now Lithuanian cases in Strasbourg raise different and difficult legal aspects under various Articles of the Convention and its Protocols (i.e., relationship between the freedom of expression and the right for respect to private life (see Armoniene v. Lithuania, No. 36919/02, Judgment, 25 November 2008), the inability to undergo full gender reassignment surgery in view of a legal vacuum (see case L. V. Lithuania); legality of the use of the secret investigation methods (see case Ramanauskas v. Lithuania [GC], No. 74420/01, Judgment, 05 February 2008); confiscation of property of the dead person (Silickiene v. Lithuania, No. 20496/02, Judgment, 10 April 2012; impeachment procedure in respect of the State President leading to the restrictions for his right to free elections under Article 3 Protocol 1 (see case Paksas v. Lithuania; the right of the former members of the soviet KGB to be employed in the civil service of the State) pending case

247 European Court of Human Rights, Annual Report 2012. Registry of the European Court of Human Rights, Strasbourg, 2013, p. 163. See also http://www.tm.It/eztt/naujiena/161. 
Vasiliauskas v. Lithuania (appl. No. 35343/05) concerning the enlarged definition of genocide in the Lithuanian laws, etc. ${ }^{248}$.

\subsection{Some Cases where the Strasbourg Court established violations of the Convention. Their impact to the Lithuanian legislation process, judiciary and strengthening of the rule of law and democracy}

\subsubsection{Restoration of property rights}

The nationalisation of the property of Lithuanian people by Soviet regime after the Second World War and Lithuania's intention to restore the property rights after the restoration of Lithuania's independence has been marked by enormous administrative difficulties and important legal changes. In order to reestablish the justice, the domestic authorities, once Lithuania regained independence in 1990, implemented a land reform. The land reform was introduced in 1991 and, according to the Programme of the Government of the Republic of Lithuania for 2008-2012, the restitution of the property is expected to be completed by the end of 2012. In October 2011, $98.25 \%$ of the nationalised property subject to restitution had been returned in rural areas and $73.90 \%$ in urban areas.

In the case Jasiūniene v. Lithuania case (Appl. No. 41510/98, judgment of 6 March 2003), which revealed the tragic history of the Baltic States and remembered the unfair and illegal nationalisation process by the Soviets, the Court relying on the principle of ratione temporis, decided that the Court is incompetent to examine some parts of the application as it was related to the events prior to the date of the entry into force of the Convention (ratione temporis, see judgment $\S 38$ ). To the extent that the applicant complained about her inability to recover the plot in kind, the Court decided that this complaint was incompatible ratione materiae within the meaning of Article $35 \S 3$ of the Convention. Finally, with regard to the authorities' failure to execute the Klaipeda's Regional Court judgment of 3 April 1996, ordering the authorities to take appropriate measures to choose the form of compensation to be afforded to the applicant in respect of her late mother's nationalised land, the Court had once more reiterated the importance of Article 6, stating that an access to a court comprises as well the execution of the court's decisions. Otherwise, a final, binding judicial decision will remain inoperative to the detriment of one party. The Court also found that, by failing to comply with this judgment, the national authorities had prevented the applicant from obtaining the compensation she could have reasonably expected to receive. When the Court rendered its judgment, the domestic judgment had still not been enforced. Finding the violation of Article 6 in this case, the Court had indirectly encouraged Lithuania to take all necessary steps to re-organize the system of the Bailiffs' Office, responsible for the execution of the decisions taken by national courts. In 2002 a newly reorganised Bailiffs' Office system was set up. The Law defines clearly the rights and responsibility of the bailiffs' ${ }^{\prime 24}$. Similar judgments finding violations of Article 1 of the Protocol 1 and Article 6 of the Convention were establish in many other Lithuanian cases ${ }^{250}$.

In the Resolution CM/ResDH(2011)2981 and its Appendix (adopted by the Committee of Ministers by tacit procedure in accordance with the decision taken at the 1128th meeting (December 2011)

\footnotetext{
248 See Paksas v. Lithuania case [GC], No. 34932/04, judgment of 6 June 2011; see also so called KGB cases EurCourtHR, Judgment of 27 July 2004, Sidabras and Džiautas v. Lithuania, 2004 - VIII, pp. 369-394; see L. v. Lithuania case, No. 27527/03, judgment of 11 September 2007 concerning the exhaustion of domestic remedies and a legal vacuum as regards the possibility to change gender; pending case before the Grand Chamber Vasiliauskas v. Lithuania, No. 35343/05 concerning the definition of genocide; etc.

249 Law on Bailiffs. 9 May 2002, No. IX-876. See:

http://www3.Irs.It/pls/inter3/dokpaieska.showdoc_l?p_id=429244

250 See Jurevičius v. Lithuania, No. 30165/02, Judgment of 11 November 2006; Igariene and Petrauskiené v. Lithuania, No. 26892/05, Judgment of 21 July 2009, etc.
} 
under item F) concerning the execution of the judgments of the European Court of Human Rights in Jasiūniene and Jurevičius ${ }^{251}$ against Lithuania, the Committee of Ministers decided to close the examination of these cases as all the measures ordered by the Strasbourg Court had been fully executed. In the Jasiūniene case, the judgment of 3 April 1996 was enforced. Pursuant to a decision of 15 April 2004, the Governor of Klaipeda allocated a plot of land to the applicant whereby her property rights with respect to her late mother's land were fully restored in kind.

In the Jurevičius case, the judgment of 5 February 1999 was also fully enforced even before the Court's judgment became final. The Municipality of Vilnius reached an agreement with the applicant whereby he was compensated by way of another flat and also received monetary compensation. Therefore in view of these circumstances, no further individual measure was deemed necessary by the Committee of Ministers.

Even accepting the fact that the Convention and the Court's case-law have direct effect in Lithuania and represent a constituent part of the Lithuanian legal system and also, that the legal principles enunciated in the present judgments are directly binding upon the domestic authorities, Lithuania is not able to finalize the restoration of property process.

Particular attention was paid to the awareness-raising measures at domestic level; however the European Court of Human Rights is still dealing with the same kind of cases against Lithuania.

In February 2013 the Court communicated to the Government of Lithuania the case Vytautas Paukštis v. Lithuania, no. 17467/07 concerning his ability to restore his nationalized property; in October 20129 applications were communicated to the Government concerning deprivation of property which had been restored to the applicants but later on taken away from the applicants by judicial decisions relying on the general interests of the State ${ }^{252}$. Varniene v. Lithuania case (No. 42916/04) regarding the reopening at domestic level of the finished case restoring the property rights to the applicant to the specific plot of land in Vilnius city was decided on 12 November 2013 finding a violation of Article 6 (legal certainty) and a violation of Article 1 of Protocol 1. Was is utmost important for the applicant and the State when executing this judgment that the Court stated that the restitution process is still going on in Lithuania and the applicant has a right to receive another plot of land of an equal value or the pecuniary compensation (see $\S 54$ of the judgment). Some other cases concerning the annulment of the property rights were also decided by the Strasbourg Court finding the violations of Article 1 of Protocol ${ }^{253}$.

Therefore it should be concluded that Lithuania is under the Convention's obligation to finalise the property restoration process and to guarantee full enjoyment of property rights. On the other hand, the Strasbourg Court has clearly recognised in its jurisprudence that Article 1 of Protocol No. 1 does not guarantee the right to acquire property (see Van der Mussele v. Belgium, judgment of 23 November 1983 , Series A no. 70, p. $23, \S 48$ ). Nor can it be interpreted as creating any general obligation for the Contracting States to restore property which had been expropriated before they ratified the Convention, or as imposing any restrictions on their freedom to determine the scope and conditions of any property restitution to former owners (see Bergauer and Others v. the Czech Republic (dec.), no. 17120/04, 4 May 2004; mutatis mutandis, Kopecký v. Slovakia [GC], no. $44912 / 98$, § 35, ECHR 2004-IX). Moreover, there is no right to acquire citizenship under the Convention and that the Contracting States are free to determine the requirements of and procedures for citizenship requests. Following the mentioned principles the case - Shub v. Lithuania

\footnotetext{
${ }^{251}$ In the Jurevičius case, the Kaunas City District Court, in its decision of 5 February 1999, obliged the authorities to offer the applicant equivalent compensation for Flat No. 1 by way of another apartment and to return Flat No. 2 to him in kind. This decision has not been executed in respect to Flat No. 1, while the decision concerning Flat No. 2 was executed with a delay of more than four years. See Internet page of the Ministry of Justice of the Republic of Lithuania - http://www.tm.lt/tm/EZTTsprendimuvykdymas/

252 See: http://www.tm.lt/eztt/naujiena/153

253 See the case Pyrantiene v. Lithuania, appl. No. 45092/07, Judgment of 12 November 2013.
} 
was declared inadmissible by the Court which noted that the Restitution of Property Act did not entitle the applicant to claim the restitution of his relatives' property because he did not meet the Lithuanian citizenship requirement. For this reason, under the domestic law the applicant had no right for a claim amounting to legitimate expectation, in the sense of the Court's case-law, therefore no "possession" within Article 1 of Protocol No. 1. Consequently, the complaints were incompatible ratione materiae with the provisions of the Convention.

Some cases in Strasbourg had ended with no violation of Article 6 and of Article 1 of Protocol No. 1 (see the judgment in the case of Užkuréliene and Others against Lithuania (application No. 62988/00, judgment of 07/04/2005; see the Court's decision of 06/03/2007 in the case of Kalpokas and Kalpokas against Lithuania (application No. 14425/03) where similar complaint were declared inadmissible).

\subsubsection{The right to examine witnesses against the accused. Fair trial aspects under Article 6}

Criminal procedure law was one of the areas which had felt very strong influence of the Convention's standards. Some Lithuanian cases which had been lost in Strasbourg had had positive impact to legislative changes in criminal law field. They had also strengthened the rule of law and common understanding of Convention human rights standards which are of fundamental importance in criminal cases.

In the case Birutis and Others v. Lithuania (Application Nos. 47698/99 and 48115/99, judgment of 28 March 2002) the applicants complained about the deprivation of their right to a fair trial and the restriction of their defence rights because they had been convicted on the basis of anonymous evidence. The Strasbourg Court found that the domestic courts' failure to question anonymous witnesses, and to conduct a scrutiny of the manner and circumstances in which the anonymous statements had been obtained, was unacceptable from the point of view of Article $6 \S \S 1$ and 3 (d) of the Convention. Some legislative changes in the Criminal procedure code followed this judgment.

Even before finding the violations in the mentioned case, Constitutional Court of Lithuania on 19 September 2000 adopted the Ruling on the same legal issue ${ }^{254}$. The Constitutional Court accepted the position that in order to protect a witness or the victim from a possible physical or psychological influence, their anonymity can be permitted in criminal procedure. However, a possibility to grant anonymity to a witness or the victim should be followed by some conditions while making use of the testimony of anonymous witnesses and victims as evidence in criminal cases. In any case, guarantees of the right to defense should be guaranteed to the accused person (the Constitutional Court of Lithuania referred to the judgments of the European Court of Human Rights in the cases of Lüdi v. Switzerland ${ }^{255}$, Doorson v. the Netherlands ${ }^{256}$ and Van Mechelen and others v. the Netherlands ${ }^{257}$ ).

After finding the violation under Article 6 of the Convention in Birutis and Others v. Lithuania ${ }^{258}$ case by the Strasbourg Court, the Code of Criminal Procedure was changed. The accused person was provided for with a possibility to challenge the evidence of anonymous witnesses ${ }^{259}$. Since the mentioned amendments, all technical and other needed possibilities have been created in order to

\footnotetext{
254 The Ruling of the Constitutional Court of Lithuania „On the compliance of Articles 118 1 , 156 ${ }^{1}$, Item 5 of Article 267 and Article $317^{1}$ of the Republic of Lithuania Code of Criminal Procedure with the Constitution of the Republic of Lithuania", 19 September 2000, in: Rulings and decisions of the Constitutional Court of the Republic of Lithuania, Vilnius, 2000, Vol. 15.

255 EurCourtHR, Judgment of 15 June 1992, Lüdi v. Switzerland, Series A No. 238.

256 EurCourtHR, Judgment of 26 March, 1996, Doorson v. the Netherlands, 1996-II, pp. 447-474.

257 EurCourtHR, Judgment of 23 April 1997, Van Mechelen and Others v. the Netherlands, 1997-III, pp. 692-730.

258 See Footnote No. 7.

259 EurCourtHR, Judgment of 28 March 2002, Birutis and Others v. Lithuania, appl. Nos. 47698/99 and $48115 / 99$.
} 
question the anonymous witnesses during the trial in order to ensure full protection of the defence rights for the accused.

On 20 July 2004 the Committee of Ministers at the 891st meeting of the Ministers' Deputies adopted the final resolution Resolution ResDH(2004)45 closing the execution in the mentioned Birutis and Others case. It came to the conclusion that there was no longer any risk of repetition of the violation found by the Court in this case.

The Committee Ministers had stressed that following the European Court's judgment finding a violation of Article 6, the Lithuanian authorities undertook a legislative reform of the abovementioned provisions. On 14 March 2002, the Lithuanian Parliament adopted a new Code of Criminal Procedure (in force on 1 May 2003). The procedure for taking evidence from an anonymous witness is laid down in Article 282. An anonymous witness may thus be questioned at a non-public hearing after appropriate acoustic and visual obstacles have been created to prevent the parties from establishing the identity of the secret witness. If such obstacles cannot be created at a court hearing, the witness should be questioned in some other place in the absence of the parties. Before questioning an anonymous witness, the party which intends to put questions to the witness should submit the questions in writing to the presiding judge. The statements made by the witness shall be recorded by the presiding judge or one of the trial judges. The presiding judge or one of the trial judges shall read out these statements at a court hearing. Additional questions may be posed under this procedure after the statements have been read out. If personal appearance in court seriously threatens the life, health or freedom of an anonymous witness or close relatives, the witness should not be summoned to appear in court, but statements made before the investigating judge should be read out at a court hearing. Such a witness may be questioned by audiovisual means after the creation of acoustic and visual obstacles.

Furthermore, the Committee of Ministers observed that in order to ensure that the new legislation is applied in conformity with the Convention, the Court's judgment has been published in Lithuanian language and such Lithuanian translation has also been transmitted to the Supreme Court of Lithuania and to the Office of the Prosecutor General of Lithuania.

The case shows clearly the direct impact to the Lithuanian legal system improving its functioning enormously from the fair trial perspectives and legislative amendments made are of crucial importance for guaranteeing the defence rights for an accused.

Lithuania has experienced a lot of problems as regards the use and application of the criminal conduct simulation model which was allowed in 1997 under the Law on Operational Activities ${ }^{260}$. Some Lithuanian cases in Strasbourg concerned the lawfulness of the application of the criminal conduct simulation model. The Grand Chamber case - Ramanauskas v. Lithuania - has formed the legal basis and guidelines for the use of the secret investigation methods including the simulation/instigation models for all countries. The Strasbourg Court decided that where an accused asserts that he was incited to commit an offence, the criminal courts must carry out a careful examination of the material in the file, since for the trial to be fair within the meaning of Article $6 \S 1$ of the Convention, all evidence obtained as a result of police incitement must be excluded. This is especially true where the police operation took place without a sufficient legal framework or adequate safeguards ${ }^{261}$.

In this case, the domestic courts found that there had been no incitement and that the authorities had not put any active pressure on the applicant to commit the offence. The Supreme Court considered that the evidence corroborated the applicant's guilt, which he himself had acknowledged. However, the European Court found that the actions of the state agents had gone

260 The Law of 22 May 1997 On Operational Activities, No. VIII-222. See:

http://www3.Irs.It/pls/inter3/dokpaieska.showdoc_I?p_id=117426\&p_tr2=2.

${ }^{261}$ Ramanauskas v. Lithuania [GC], Appl. No. 74420/01, Judgment of 5 February 2008, §§ 52-61. 
beyond the mere passive investigation of existing criminal activity: there was no evidence that the applicant had committed any offences before, in particular corruption-related offences. All the meetings between the applicant and the agents took place at their initiative and the applicant seemed to have been subjected to blatant pressure on their part to commit a criminal act, whereas there was no objective reason to suppose that he intended to do so. Therefore, the domestic authorities and courts should at the very least have undertaken a thorough examination, especially as regards the allegation that the authorities went beyond the limits of the authorized simulation model. The national courts should have established in particular the reasons why the operation had been mounted, the extent of the police's involvement in the offence and the nature of any incitement or pressure to which the applicant had been subjected. After this case, the Law on Operational activities has been changed in order to comply with the Convention standards ${ }^{262}$.

In the Resolution CM/ResDH(2011)2311 and its Appendix adopted on 2 December 2011 at the $1128^{\text {th }}$ Meeting of the Ministers' Deputies as regards the execution of the judgments of the European Court of Human Rights in the Ramanauskas and Malininas against Lithuania cases, the Committee decided to close the execution in both cases.

It was noted that Mr. Ramanauskas was released on probation in January 2002 and the decision prohibiting him from working in law enforcement institutions was lifted. Following the Court's judgment, the applicant applied for reopening of the criminal proceedings. By decision of 16 December 2008, the Supreme Court quashed the applicant's conviction and discontinued the reopened criminal case. The damage awarded to the applicant was also paid.

In the Malininas case, no damage was awarded. The applicant submitted a request to the Supreme Court to reopen the criminal proceedings. In December 2008, the Supreme Court decided to reopen the proceedings. However, the applicant and the Prosecutor withdrew their appeals, subsequently, these appeals were left unexamined and the criminal proceedings were terminated. The applicant thus voluntarily and irreversibly waived his right to a retrial of his case.

As regards general measures, in order to prevent similar violations, the Supreme Court of Lithuania set out (Decision of 16 December 2008) the general principles with regard to cases where the criminal conduct simulation model is employed. The criminal conduct simulation model as an investigative technique may not be employed to incite the commission of an offence but may be applied only if credible and objective information had already been obtained to the effect that the criminal activity had been initiated. The State officials may not act as private persons to incite third parties to commit an offence [...]. The burden of proof in judicial proceedings lies with the state authorities. No evidence obtained through incitement shall be admissible. The confession of an offence as a result of incitement does not eradicate either incitement or its effects. And finally, it is preferred that undercover techniques are supervised by a court although supervision by a prosecutor does not in itself violate the Convention. This decision of the Supreme Court is binding upon all domestic courts and demonstrates clearly the direct influence of the Strasbourg Court's jurisprudence to the national judiciary and its practice.

The legal requirement of a fair trial was problematic not only in criminal cases, but in the administrative procedure as well. In the case Gulijev v. Lithuania ${ }^{263}$ the Strasbourg Court found the procedural violation of Article 8 of the Convention. The administrative courts of Lithuania when deciding on the applicant's expulsion from Lithuania to Azerbaijan not only used a "secret" report as an evidence in the case, when the applicant and his lawyer had no access whatsoever to this report, but furthermore, this "secret" report was the sole ground for not granting the applicant a temporary residence permit. As a result, he was deported from Lithuania until 2099 is prohibited from reentering Lithuania, where his two children and wife, all of whom were Lithuanian citizens, live.

262 In the cases Malininas v. Lithuania, Appl. No. 10071/04, Judgment of 1 July 2008; Lalas v. Lithuania, No. 13109/04, Judgment of 1 March 2011 the same problem was detected.

263 Gulijev v. Lithuania, Appl. No. 10425/03, 16 December 2008, § 44. 
Paradoxically, the European Court sent a clear message to the national administrative courts in 2008 that as a rule, factual data which constitutes a State secret may not be used as evidence in an administrative case until it has been declassified. However, this rule was introduced by the Supreme Administrative Court itself already in September 2002. Pity that such rule was not followed in the examination of this case. Following the conclusion in Gulijev v. Lithuania case, the European Court of Human Rights established also the violations of the fair trial requirements under Article 6 of the Convention in other cases against Lithuania - i.e., Pocius v. Lithuania and Užukauskas v. Lithuania ${ }^{264}$. The Court applied in both cases Article 6 of the Convention under its civil limb. In the Pocius case it was decided that the information contained in the operational records file about the applicant was deemed to be essential evidence of the applicant's alleged danger to society which was not disclosed to him, even in part. It was not, therefore, possible for the applicant to have been apprised of the evidence against him or to have had the opportunity to respond to it, unlike the police who had effectively exercised such rights (see, mutatis mutandis, Gulijev v. Lithuania, no. 10425/03, § 44, 16 December 2008). The Court finding a violation of Article 6 of the Convention came to the conclusion that the decision-making procedure did not comply with the requirements of adversarial proceedings or equality of arms, and did not incorporate adequate safeguards to protect the interests of the applicant. The same conclusion was reached in Užukauskas v. Lithuania case ( $\$ 50)$, where the operational records file was the only evidence of the applicant's alleged danger to society, which was never disclosed to him.

In the Resolution CM/ResDH(2010)175 (adopted by the Committee of Ministers on 2 December 2010 at the 1100th meeting of the Ministers' Deputies) concerning the execution of the judgment in the mentioned case Gulijev against Lithuania, the Committee of Ministers closed the execution of the case as all individual and general measures had been undertaken by the respondent Government. On 22 May 2009 of the Migration Department of Lithuania decided to remove the data concerning the applicant from the national list of aliens prohibited from entering Lithuanian Republic territory. Consequently the applicant may now enter the Republic of Lithuania whenever he wishes and is entitled to apply to the migration department for a temporary residence permit. Consequently, no other individual measure was considered necessary by the Committee of Ministers. Even more, the Lithuanian authorities considered that that the violation in this case was purely due to a wrongful application and interpretation of domestic law, since despite Article $57 \S 3$ of the Law on Administrative Proceedings which makes it illegal to take into account as an evidence a document classified as "secret", the expulsion of the applicant was based on a "secret" document drafted by the State Security Department, to which the applicant had no access during the expulsion proceedings. In addition, in a decision of 15/05/2007, the Constitutional Court, when interpreting Article $57 \S 3$ of the Law on Administrative Proceedings, considered clearly that "no court decision can be based entirely on information classified as secret and which is unknown to the parties in the case"265.

Taking into account the violations of Article 6 found in the mentioned cases in Strasbourg ${ }^{266}$, the Supreme Administrative Court in its decision of 8 October 2009 in the administrative case No. A(822)-326/2009 (Reporting judge S. Žalimienè) decided that from the jurisprudence of the European Court of Human Rights it is quite clear that factual data which constitutes a State or official secret being the sole or the most important evidence in the case may not be used as evidence in an administrative case until it has been declassified. The administrative court decided that the secret

264 Pocius v. Lithuania, Appl. No. 35601/04, 6 July 2010, §§ 43, 38-46, 55-58; Užukauskas v. Lithuania, Appl. No. 16965/04, 6 July 2010, §§ 48-50. It should be also noted that the case Shivan Zuber Alzuhari v. Lithuania (No. 16688/06) was communicated in March 2011 to the Lithuanian Government, where the applicant alleges that while examining his expulsion from Lithuania, the Lithuanian courts relied on the secret information concerning the applicant's alleged danger to the security which was not disclosed to the applicant.

265 http://www.tm.It/dok/Res_GULIJEV.pdf

266 See cases Pocius v. Lithuania, Užukauskas v. Lithuania, Gulijev v. Lithuania, Footnotes Nos. 44, 46. 
operational information supplied by the police to the administrative courts was the only evidence in that case against the applicant. For this reason, official warning applied in respect of the applicant was annulled and the decision of the lower court was abolished.

It should also be remembered that the use of the secret documents as evidence in the administrative cases was prohibited by the Supreme Administrative Court's judgment on 4 September 2002 in the case no. A10-786-02, where the Court decided:

"as a rule, factual data which constitutes a State or official secret may not be used as evidence in an administrative case until it has been declassified (Article $57 \S 3$ of the Law on the Administrative Proceedings). Therefore, in the absence of other evidence, [the lower] court had no legal basis in relying solely on written information, provided by the State Security Department, which was marked as secret".

The Law on Administrative Proceedings (Administraciniy byly teisenos jstatymas) provides in Article 57 (Evidence) the same rule:

"[...] 3. As a rule, factual data which constitutes a State or official secret may not be used as evidence in an administrative case, until the data has been declassified in a manner prescribed by law."

However, having elaborated this excellent rule on the fairness of the procedure already in 2002, the administrative courts, pity to say, have not always observed it in their practice.

The same problem was detected in some other cases against Lithuania - i.e., Pocius v. Lithuania and Užukauskas v. Lithuania ${ }^{267}$. The Court dismissed the Government's objection that the applicants' complaints are incompatible ratione materiae and decided that in both cases to apply Article 6 of the Convention under its civil limb. In the Pocius case the Strasbourg Court decided that the information contained in the operational records file about the applicant was deemed to be essential evidence of the applicant's alleged danger to society which was not disclosed to him, even in part. It was not, therefore, possible for the applicant to have been apprised of the evidence against him or to have had the opportunity to respond to it, unlike the police who had effectively exercised such rights (see, mutatis mutandis, Gulijev v. Lithuania, no. 10425/03, § 44, 16 December 2008). The Court finding a violation of Article 6 of the Convention came to the conclusion that the decision-making procedure did not comply with the requirements of adversarial proceedings or equality of arms. The same conclusion was reached in Užukauskas v. Lithuania case $(\S 50)$, where the operational records file was the only evidence of the applicant's alleged danger to society, which was never disclosed to him. Furthermore, whilst, before dismissing the applicant's case, the Lithuanian judges did examine, behind closed doors and in their chambers, the operational records file, they merely presented their conclusions to the applicant who have had no opportunity to respond to it, unlike the police who had effectively exercised such rights. The use of the secret documents as the evidence in the files is not only the problem of the administrative courts; this is a common problem of other Lithuanian courts as well ${ }^{268}$.

\subsection{3. "KGB" cases. Their impact to the democratisation process}

Four other joined cases - Sidabras and Džiautas v. Lithuania ${ }^{269}$ and Rainys and Gasparavičius v. Lithuania $^{270}$ had raised an important issue of the rule of law, the principle of legal certainty and necessity of some restrictions to a work in a democratic society. These cases concern so called

267 Pocius v. Lithuania, Appl. No. 35601/04, 6 July 2010, §§ 43, 38-46, 55-58; Užukauskas v. Lithuania, Appl. No. 16965/04, 6 July 2010, §§ 48-50. It should be also noted that the case Shivan Zuber Alzuhari v. Lithuania (No. 16688/06) was communicated in March 2011 to the Lithuanian Government, where the applicant alleges that while examining his expulsion from Lithuania, the Lithuanian courts relied on the secret information concerning the applicant's alleged danger to the security which was not disclosed to the applicant.

${ }^{268}$ See mutatis mutandis Drakšas v. Lithuania, Application no. 36662/04, Judgment of 31 July 2012, § 68.

269 EurCourtHR, Judgment of 27 July 2004, Sidabras and Džiautas v. Lithuania, 2004 - VIII, pp. 369-394.

${ }^{270}$ Case Rainys and Gasparavičius v. Lithuania, appl. Nos. 70665/01 and 74345/01, judgment of 7 april 2005. 
"former workers" of KGB under the Law on the Evaluation of the USSR State Security Committee (NKVD, NKGB, MGB, KGB) and the Present Activities of Former Permanent Employees of the Organisation ("the KGB"). The mentioned Law was enacted on 16 July 1998 by the Lithuanian Seimas (Parliament) with the validity of 10 years. The Strasbourg Court was obliged, firstly, to determine whether the Article $6 \S 1$ is applicable to "the KGB" members' cases. It was subsequently established that Article 6 of the Convention was not applicable in relation with the proceedings concerning the applicants' dismissal from the public sector and the restrictions on their employment in the civil service prospects because it did not concern either "a criminal charge" or "civil rights" within the meaning of Article $6 \S 1$ of the Convention 271 (Pellegrin v. France judgment ([GC], no. 28541/95, §§ 64-71, Reports of Judgments and Decisions 1999-VIII was relied on and the functional criteria established therein). The Court considered, as regard the criminal field, that that the Law does not belong to Lithuanian criminal law, but to the sphere of employment law. Nor can the fact of being a former member of the Soviet secret services be described as "a criminal offence".

The applicants complained about lack of an access to "a court" and fair trial, stating that they were discriminated as the former KGB workers with regard to Articles 6, 8, 10 and 14, and also, they were punished retroactively without any basis in law under Article 7 of the Convention. Accepting the fact, that the restriction of the applicants' employment prospects under the KGB Act, and the difference of treatment applied to them, pursued the legitimate aims of the protection of national security, public safety, the economic well-being of the country and the rights and freedoms of others (see, mutatis mutandis, Rekvényi v. Hungary, [GC], no. 25390/94, § 41, ECHR 1999- III), the Court noted that the measures constituted a disproportionate burden on the applicants, even having regard to the legitimacy of the aims pursued by that ban. The Court ruled that the State-imposed restrictions on a person's opportunity to find employment within a private company for the reasons of lack of loyalty to the State cannot be justified from the perspective of the Convention in the same manner as restrictions in the public service. In the Court's view, the Lithuanian legislator should have considered the necessary safeguards for avoiding discrimination and for guaranteeing an appropriate judicial supervision of the imposition of such restrictions. Finally, the Strasbourg Court observed that the KGB Act came into force in 1999, that is, almost a decade after Lithuania declared its independence on 11 March 1990; in other words, the restrictions on the applicants' professional activities were imposed on them thirteen years and nine years respectively after their departure from the KGB. This fact is not of itself decisive, but may none the less be considered relevant to the overall assessment of the proportionality of the measures taken. Therefore, there has been a violation of Article 14 of the Convention taken in conjunction with Article 8. Quite importantly, it should be mentioned that the European Court of Human Rights established the violations of the Convention in the mentioned "KGB cases” after the Constitutional Court of Lithuania in the Ruling of 4 March $1999^{272}$ declared Articles 1 and 2 of "the KGB" Law as being compatible with the requirements of the Lithuanian Constitution. According to the Constitutional Court, a check-up of civil servants is necessary, as they are State officials directly linked with wide and responsible powers.

\footnotetext{
${ }^{271}$ EurCourtHR, Decision as to the Admissibility of 1 July 2003, Case Sidabras and Džiautas v. Lithuania, op. cit. (note 19) and see also EurCourtHR, Decision as to the Admissibility of 22 January 2004, Case Rainys and Gasparavičius v. Lithuania, op. cit. (Footnote 49).

272 The Ruling "On the compliance of Articles 1 and 2, Part 2 of Article 3 of the Republic of Lithuania Law "On the Assessment of the USSR Committee of State Security (NKVD, NKGB, MGB, KGB) and Present Activities of the Regular Employees of This Organisation" as well as Parts 1 and 2 of Article 1 of the Republic of Lithuania Law on the Enforcement of the Law "On the Assessment of the USSR Committee of State Security (NKVD, NKGB, $M G B, K G B)$ and Present Activities of the Regular Employees of This Organisation" with the Constitution of the Republic of Lithuania", 4 March 1999, in: Rulings and Decisions of the Constitutional Court of the Republic of Lithuania, Vilnius, 1999, Vol. 12.
} 
In the same Ruling the Constitutional Court stated that decisions taken by different State bodies (not by the courts) in reality do not guarantee an opportunity for an individual to appeal to court against those decisions, which contradict Part 1 of Article 30 of the Constitution of the Republic of Lithuania in respect of the right to apply to the court. After the Ruling was adopted, the KGB Law was changed in order to guarantee the right to apply to the court against the decision of administrative bodies.

Furthermore, this example shows clearly that the Constitutional Court cannot prevent the legal problems which had already been discussed before the Constitutional Court, to be raised once again in Strasbourg. Even more, the European Court of Human Rights can come to different conclusions. And this can be understandable, as the Constitutional Court of Lithuania is ensuring the conformity of the Lithuanian laws with the Convention ${ }^{273}$. However, such constitutional control, in principle, should have presupposed also the compatibility with the Convention requirements, even the individual petition rights is not guaranteed in the Constitution of Lithuania.

The mentioned cases had raised a lot of political and legal discussions in Lithuania. Taking into account similar cases in Strasbourg against other states, the question as regards the State's margin of appreciation in this field can be raised ${ }^{274}$. Whether the State can freely introduce the loyalty requirement for the public service and/or whether such requirement must be limited and if yes, to what extend. Lithuania is not a very good example to answer to the question raised above. The country had not been able to change the provisions of "the KGB Law" until 2009 when the Law ceased its validity. Although the European Court of Human Rights had established the violations of the Convention in all mentioned 4 cases, and the Committee of Ministers was supervising the execution of judgments as regards the general measures, political will in the Seimas of Lithuania was not present for changing the mentioned Law. It should also be noted that 3 applicants from the previous cases came again to Strasbourg claiming about the continuous violations of their right as the Law had not been changed until 2009. These cases are pending before the Court and were communicated to the Lithuanian Government. The Vetting Law of Lithuania had remained unchanged either (ceased its validity in 2009 as well (see the case Žičkus v. Lithuania ${ }^{275}$ ). It means that Lithuania has not executed the judgments under Article 46 of the Convention and did not fulfil its international obligations under the Convention.

All the mentioned judgments revealing the old soviet system should have encouraged Lithuania to think more "in the present day conditions" as required by the Convention's jurisprudence and to reconsider the past even very tragic one. Political circumstances of the cases should not prevail over the legal requirements of the new democratic European societies.

Hopefully in the future Lithuania will not any more experience the same kind of problems as all Laws in this field are not in force any more.

In the same field the case Paksas v. Lithuania ([GC], No. 34932/04, judgment of 6 June 2011) - the impeached President's case - can be mentioned. After the Impeachment procedure organized against the Head of the State in Lithuania in 2004 by the Constitutional Court the Strasbourg Court decided that the restrictions placed on the impeached President's right to participate in the free parliamentary elections for the whole life are disproportionate and not necessary in the democratic society.

\footnotetext{
${ }^{273}$ Egidijus Kūris, op. cit. (Footnote 13), p. 29.

274 See Matyjek v. Poland, Application No. 38184/03, Judgment of 24 April 2007; Bobek v. Poland, Application No. 68761/01, Judgment of 17 July 2007.

275 Žičkus v. Lithuania, no. 26652/02, 7 April 2009. See also case Sidabras and Džiautas v. Lithuania (nos. $55480 / 00$ and 59330/00, 1 July 2003, §§ 47-50, ECHR 2004-VIII) concerning the employment restrictions in the private sector placed on the former KGB.
} 


\subsubsection{Independent and impartial courts in Lithuania}

The case -Daktaras v. Lithuania - where the European Court of Human Rights had established that the applicant who at that moment was described as the Leader of Lithuanian Mafia, was convicted by the court which had not been "... an independent and impartial tribunal ...". The Court noted that the President of the Criminal Division of the Supreme Court of Lithuania lodged a petition with the judges of that division asking to quash the Court of Appeal's judgment, followed the first-instance judge's request. The President proposed the quashing of the Court of Appeal's decision and the reinstatement of the first-instance judgment. The same President then appointed the judge rapporteur and constituted the Chamber to examine the case. The President's petition was endorsed by the prosecution at the hearing and eventually upheld by the Supreme Court. In the consideration of the Court such an opinion cannot be regarded as neutral from the parties' point of view...". Consequently, the Court has found a breach of Article $6 \S 1$ of the Convention ${ }^{276}$. After the judgment of the European Court of Human Rights which raised many discussions in Lithuania and to some extent disappointment in society, the proceedings were re-opened at domestic level and the applicant was re-trialled ensuring all guarantees of the Convention. The new Criminal Procedure Code of Lithuania (effective from 1 May 2003) establishes the exceptional possibility to re-open criminal cases where the judgments have already become final, after the adopted judgments of the European Court find a violation of the Convention or its Protocols thereof (Chapter XXXV).

In the Resolution ResDH(2004)43 concerning the judgment in the case of Daktaras against Lithuania (adopted by the Committee of Ministers on 20 July 2004 at the 891st meeting of the Ministers' Deputies) and the Appendix to Resolution it's clear that Lithuania executed fully the judgment. On 2 April 2002 a plenary session of the Criminal Chamber of the Supreme Court annulled the cassation judgment which had been adopted by this same Chamber on 2 December 1997. According to the new judgment, the cassation petition submitted by the President of the Criminal Chamber of the Supreme Court was not taken into account. The cassation petition submitted by $\mathrm{Mr}$ Daktaras, as well as that of his legal representative, were rejected. As far as general measures are concerned, the new Lithuanian Code of Criminal Procedure (Baudžiamojo proceso kodeksas) provides for the possibility of entitling certain judges including the Presidents of Divisions of the Supreme Court to submit a cassation petition, has been repealed. This case influenced directly the legislation of Lithuania establishing the guarantees as regards the independence and impartiality of the judiciary.

\subsubsection{Pressumption of Innocence}

In another Lithuanian case - the case Butkevičius v. Lithuania, the applicant (who was the former minister of Defence of Lithuania) complained that the statements of the Chairman of the Seimas (Parliament) published on 15 and 20 August 1997 and 6 October 1998 breached Article $6 \S 2$ of the Convention (presumption of innocence). The applicant was charged with an offence of bribery. The Chairman of the Seimas entertained in his statements that there was no doubt that the applicant had accepted a bribe, that he had taken money "while promising criminal services", and that he was a "bribe-taker". In this respect the Court had particular regard to the fact that the Seimas had lifted the applicant's parliamentary immunity to enable criminal proceedings to be instituted against him. Acknowledging the fact that the applicant was an important political figure at the time of the alleged offence, nevertheless, the Court decided that the impugned remarks of the Chairman of the Seimas were in each case brief and made on separate occasions and amounted to declarations by a high public official of the applicant's guilt, which served to encourage the public to believe him guilty and prejudged the assessment of the facts by the competent judicial authority. Therefore, the presumption of innocence of the applicant had been breached.

${ }^{276}$ EurCourtHR, Judgment of 10 October 2000, Daktaras v. Lithuania, 2000-X, pp. 491-505. 
In the Resolution ResDH(2004)58 concerning the execution of this judgment the Committee of Ministers on 12th October 2004 at the 897th meeting of the Ministers' Deputies closed the execution in that case, as Lithuania had fully executed the judgment. As regards detention on remand problems in Lithuania under Article 5, the Committee of Ministers noted that the same kind as those found in this case had already previous existed in the country (see ResDH(2004)56 in the case of Jéčius against Lithuania), however, through the entry into force, on 1 May 2003, of the new Code of Criminal Procedure, the relevant provisions were set out elaborating an exhaustive list of specific grounds and requirements to be met before imposing or extending detention on remand; and, in particular, that under Article 130 of the new Code, the complaints challenging the lawfulness of detention on remand, filed by the detained person or his defense counsel, have to be examined in a public hearing, to which the arrested person and his/her defense counsel have to be summoned. Interesting part of the execution in this case concerned the presumption of innocence aspect, where very high Lithuania politician, the speaker of the Seimas, was involved. The Committee of Ministers agreed with the Government that sending directly the letter to the authorities directly concerned about the violation for their actions could be regarded as sufficient general measure in the case. When in the beginning of the "Strasbourg Convention application" in Lithuania Article 5 (together with Article 6) was the main Article for finding the violations in the Lithuanian cases (especially as regards the unlawfulness of the detention and its long and not reasonable duration), in the last years those violations have disappeared with the implementation of the new Criminal Procedure rules from $2003^{277} .80$.

Lastly, it should be mentioned one of the newest cases lost in Strasbourg under Article 5 of the Convention - Venskute v. Lithuania (appl. No. 10645/08, judgment of 11 December 2013), where the Court was confronted with the arbitrary deprivation of liberty of the applicant by two members of the State Border Guard Service. The Court had had occasion to hold that the absence of an arrest record must in itself be considered a most serious failing, as it has been the Court's constant view that unrecorded detention of an individual is a complete negation of the fundamentally important guarantees contained in Article 5 of the Convention and discloses a most grave violation of that provision. Hopefully such accidents will not occur any more, as it was based only on the unique accident and arbitrary actions of the mentioned servants, and not on the legal incorrect provisions of the laws.

\subsubsection{Prison conditions - Censorship of the Correspondence}

Prison conditions are one of the most important difficulties for the Lithuanian authorities which had been established in the cases lost in Strasbourg. Of course, Lithuania is not a unique European country experiencing such problems. Many other States have lost many cases in Strasbourg concerning the prison and/or detention on remand conditions (see cases Peers v. Greece, no. 28524/95, §§ 67-68, 74, ECHR 2001-III; Kalashnikov v. Russia, no.47095/99, § 97, ECHR 2002-VI; Torreggiani and Others v. Italy, nos. 43517/09, 46882/09, 55400/09, 57875/09, 61535/09, 35315/10 and $\underline{37818 / 10}$, §§ 65-69, 8 January 2013; see also Ananyev and Others v. Russia, nos. $\underline{42525 / 07}$ and 60800/08, 10 January 2012, etc).

In the case Savenkovas v. Lithuania ${ }^{278}$ the Court found also a violation of Article 8 as regards the censorship of prisoners' correspondence. The Court recalled that it had on a number of occasions criticised the relevant Lithuanian legislation, and particularly its rather vague definition of the word "censorship", which had resulted in a number of cases of abuse by the authorities in their extensive screening or withholding of detainees' correspondence (see Jankauskas v. Lithuania, no. 59304/00, $\S \S 19-23,24$ February 2005; Čiapas v. Lithuania, no. 4902/02, §§ 24-26, 14 November 2006). In the

277 See cases Jéčius v. Lithuania, appl. No. 34578/97, judgment of 31 July 2000; Graužinis v. Lithuania, appl. No. 37975/95, judgment of 10 October 2000; see also Vaivada and Vaivada v. Lithuania, appl. Nos. 66004/01 and 36996/02, judgment of 16 November 2006, etc.

278 Savenkovas v. Lithuania, appl. No. 871/02, judgment of 18 November 2008. 
Savenkovas case the Court noted that the domestic law and practice did not clarify the criteria which could have justified a blanket system of censorship of prisoners' correspondence and such an extensive control of the applicant's correspondence was not "necessary in a democratic society". It could be presupposed that the administrative courts could directly rely on this judgment when examining the cases concerning the censorship of the prisoners' letters and explaining the discretionary powers of the prison administration in this field and finally, outlining the situations where such censorship would be proportionate and justified.

As regards the applicant's complaints in this Savenkovas case about violation of his personal rights on account of the inadequate general conditions of detention, the Court found the violation of Article 3 of the Convention as regards the overcrowding problem in Lukiškès Prison, noting that Vilnius Regional Administrative Court rejected the applicant's claims in a succinct and global manner.

The applicant claimed that 2 to 8 persons had had to share a cell of about $9 \mathrm{~m}^{2}$, all the detainees being confined to the cell for most of the day. The Government contended that there had been some $2.86 \mathrm{~m}^{2}$ of floor space per person in that institution at the material time. However, the Court noted that the CPT found less available space during its visit in $2000-1.3 \mathrm{~m}^{2}$ per person - which had further deteriorated by the time of their second visit to that prison in 2004 to $1.16 \mathrm{~m}^{2}$. Moreover, each cell at Lukiškès prison had had an open toilet without sufficient privacy. In addition, as a remand prisoner, the applicant had been obliged to stay in such cramped conditions some 23 hours a day, with no access to work, or educational or recreational facilities (see also the judgments of Karalevičius v. Lithuania, appl. No. 53254/99, judgment of 7 April 2005, §§ 34-41; Kasperovičius v. Lithuania, appl. No. 54872/08, judgment of 20 November 2012, where the Court found a violation of Article 3 as regards the conditions of the applicant's detention in the Anykščiai Police Detention Facility during his detention on remand).

Savenkovas judgment can be interpreted as sending a clear signal to the domestic authorities requiring to take general measures in order to improve the penitentiary system (i.e., to renovate prisons, to build new ones, and/or to improve the general prison/detention conditions. Some initiatives are taken at the Ministry of Justice level and the Norway has promised to provide its financial help in implementing the Project allowing the modernisation of the Lithuanian penitentiary system ${ }^{279}$. However, such measures require a lot of not only financial means, but also complex administrative, legal and logistical measures. It's too early to speak about general measures while implementing the mentioned Court's judgments in Lithuania, as no visible steps for the moment have been realised in order to improve the penitentiary system and the conditions therein. Some similar cases are still pending before Strasbourg Court.

\section{Interaction between the European Court of Human Rights and national Courts of Lithuania}

Without taking into account the fact that traditional Lithuanian jurisprudence is based mostly on the domestic sources of law, the European Convention on Human Rights as well as other International treaties ratified by Lithuania have the power of law and are directly applied by the Lithuanian courts, especially by the Constitutional Court, the Supreme Administrative Court and also by the Supreme Court of Lithuania. Other Lithuanian courts apply the Convention in their jurisprudence as well. With regard to the European Convention, it can be concluded that the Convention has become a real practical instrument for the protection of human rights in Lithuania.

Luzius Wildhaber addressing the international conference in Vilnius to celebrate the $10^{\text {th }}$ anniversary of the Constitution of Lithuania emphasised that: 280

\footnotetext{
279 http://www.tm.lt/naujienos/pranesimasspaudai/1927

280 Luzius Wildhaber. Recent case-law of the European Court of Human Rights, in: Constitutional Justice and the Rule of Law. The Constitutional Court of the Republic of Lithuania, Vilnius, 2004. P. 70-71.
} 
[...] Like the European Court of Justice, the European Court of Human Rights has always attached the greatest importance to its relationships with the superior national Courts, and in particular national constitutional courts [...].

[...] From its earliest judgments the Court recognised the subsidiary character of the Convention system, by which it meant that it was primarily for the national authorities and particularly the national judicial authorities to secure the rights enshrined in the Convention. This places the burden mainly on the Supreme and Constitutional Courts, which the European Court sees as forming a partnership with it within the system of protection set up by the Convention. [...] The international judge owes a degree of deference to decisions taken by national democratic institutions in full compliance with the rule of law, and although that deference will never exclude the international review completely, it will call for some measure of judicial self restraint at international level [...].

The Constitutional Court of the Republic of Lithuania, which is a part of the judiciary, but it does not belong to the common judicial system ${ }^{281}$, refers to the jurisprudence of the European Court of Human Rights very often.

The Constitutional Court of the Republic of Lithuania in its Ruling On the compliance of item 7, Part 1 of Article 37, Article 39, Parts 1 and 2 of Article 40, Article 45 and Parts 2 and 3 of Article 46 of the Law of the Republic of Lithuania on Commercial Banks with the Constitution of the Republic of Lithuania ${ }^{282}$, when analyzing the legitimate restrictions which could be imposed on property rights, stated that the fundamentals of the content of any basic human right may not be violated by restrictions. Referring to the jurisprudence of the European Court of Human Rights in this field, the Constitutional Court had stated that:

"[...] It is pointed out in the review of practical application of the Convention by the European Commission of Human Rights and the European Court of Human Rights: Part 2, Article 1 of the First Protocol establishes that the laws which the State deems necessary to control the use of property in accordance with the general interest do not violate the said Article of the Convention. In the aforementioned provision of Article 1 a well-known legal principle is expressed which is recognised by every State of the Convention: the legislator is entitled to establish rules restricting opportunities of property owners in the general interest. Of course, such rules are much varied. The Court controls the measures adopted by the States under the rule of proportionality (The European System for the Protection of Human Rights/ R.St.J.Macdonald, F.Matcher, H.Petzold (Eds.), 1993. P. 526)".

The Constitutional Court had stated that the provisions of $\S 2$ of Article 1 of Protocol 1 of the Convention, however, in any way impair the right of a State to enforce such laws as it deems necessary to control the use of property in accordance with the general interest or to secure the payment of taxes or other contributions or penalties. The Constitutional Court came to the conclusion that the protection of private property as established in the Constitution agrees in essence with the international understanding of protection of the right to property.

It should also be noted that the text of the Constitution of Lithuania contains some legitimate limitations with regard to human rights. Such limitations are very similar to those stated in the Convention. The fundamental human rights according to the Constitution can be legitimately restricted in accordance with the law, when it is necessary in a democratic society on grounds of public interest or interest of society, when they are in conflict with other fundamental rights and fair balance must be established, they can also be restricted to safeguard health, honour and dignity, private life or morals of a person, or for the protection of constitutional order, etc. The

\footnotetext{
${ }^{281}$ Egidijus Kūris. Constitutional Justice in Lithuania: The First Decade, in: Constitutional Justice and the Rule of Law, Vilnius, the Constitutional Court of the Republic of Lithuania, 2004, p. 27.

282 The Ruling of the Constitutional Court of the Republic of Lithuania "On the compliance of item 7, Part 1 of Article 37, Article 39, Parts 1 and 2 of Article 40, Article 45 and Parts 2 and 3 of Article 46 of the Law of the Republic of Lithuania on Commercial Banks with the Constitution of the Republic of Lithuania", 18 April 1996, in: Rulings and decisions of the Constitutional Court of the Republic of Lithuania, Vilnius, 1996, Vol. 6.
} 
Constitutional Court of Lithuania interprets all such limitations in its practice giving to every of such notion very concrete and visible content ${ }^{283}$.

As the Convention is described as "the living instrument" which must be interpreted in present days conditions (see the case Christine Goodwin v. the United Kingdom, appl. No. 28957/95, judgment of 11 July 2002, §§ 74-75), the Constitution of Lithuania must also be interpreted under the dynamic and present days conditions' approach. Due to this aspect, Egidijus Kūris, the former President of the Constitutional Court of Lithuania, was of the opinion, that „,...] the new paradigm of constitutional law is fully formed because it can be influenced by new factors to be regarded [...]. From the point of view of time of the Lithuanian integration into the European Union and the transformation of the constitutional law paradigm are parallel processes and their relationship is still to be considered [...]. To match the aspirations of the participation in the European integration with the new constitutional paradigm, one will need not only formal amendments to the Constitution but also correctives of the official constitutional doctrine"284. This is the fact for Lithuania as a new Member State in the European Union to take into account all specific features of the EU law and the possible EU Constitution, trying to co-ordinate the application of all those instruments in the national courts as a parallel process. And, the conclusion can be reached that the Constitutional Court of Lithuania is successfully doing so.

The Supreme Court of the Republic of Lithuania refers to the jurisprudence of the European Court of Human Rights as well. More importantly, in the Supreme Court's decision of 24 May 1999 (the Civil case No. k-3-165/99) Category 47) the main principles were developed in respect of the application of the European Convention of Human Rights:

\begin{abstract}
"...when solving any question related to human rights, in every case it should be taken into account that the Republic of Lithuania has ratified the European Convention of Human Rights and Fundamental Freedoms and its additional Protocols. The Convention is applicable not only with regard to the Lithuanian citizens but also it applies to the foreigners who are residing legally in Lithuania due to the fact that Article 1 of the Convention provides for guarantees for every individual under the jurisdiction of the State Party to the Convention...".
\end{abstract}

This was the fundamental position undertaken by the Supreme Court laying down the main legal framework under Article 1 of the Convention for effective application of the Convention at national level.

Furthermore, in the Supreme Court's decision of 9 June 1999 (the Civil case No. 3K-3-271/1999) Category 5) it had been stated that: „[...] the Law (Articles 146-148 of the Code of Civil Procedure) provides for the minimum requirements for the content and form of the suit [...]". Referring to Article 13 of the Convention with regard to an effective legal remedy before a national authority, the Supreme Court came to the conclusion that the minimum requirements for the content and form of the suit stated in the Law cannot be regarded as an obstacle for the constitutional right to apply to the Court or even as a violation of Article 13 of the Convention, because the right to apply to a court must be ensured under the requirements of the domestic law.

Very interesting position of the Supreme Court (the Rapporteur judge V. Mikelenas) is stated in the Civil case of Michailas Bolotovas (the Civil case No. 3K-3-895/2003) Category 39.6.2.3), where the Supreme Court analysed the practice of the application of Article 5 of the Convention with regard to the applicant's detention and compensation thereof in the framework of civil claim for compensation of such illegal and lengthy detention. Relying on the European Court's of Human Rights jurisprudence in application of Article 5 (Lawless v. Ireland case, judgment of 1 July 1961, Fox, Campbell and Hartley v. the United Kingdom case, judgment of 30 August 1990, Punzelt v. the Czech Republic case, judgment of 25 April 2000, Jéčius v. Lithuania case, judgment of 31 July 2000, etc.),

283 Danutè Jočienè. Concretization of and Limitations on Fundamental Rights, VU Mokslo darbai, Teise, 2002, Nr. 44, pp. 54-71.

${ }^{284}$ Egidijus Kūris, op. cit. (Footnote 13), pp. 38-39. 
the Supreme Court in this civil case stated that the lower courts had not analysed the question concerning the applicant's detention under the requirements of $\S 3$ Article 5 of the Convention and, therefore, the decision of the appeal instance must be abolished and the case must be sent back to a lower court for re-examination.

The Supreme Court of Lithuania (the Rapporteur judge V. Mikelenas) also addressed the jurisprudence of the European Court of Human Rights in the Civil case No. 3K-3-384/99 (Category 35) as regards the right to apply to a court in the property restitution cases. In the opinion of the Author, this is one of the most principal positions of the Supreme Court concerning the application of the Convention in Lithuania:

[...] a right to a court as well as a right to property are one of the fundamental human rights which are protected in the European Convention on Human Rights [...]. Since the ratification of the Convention by Lithuania it became the constituent part of the Lithuanian legal system and the Lithuanian courts must interpret and apply the national laws in the framework of the Convention and, moreover, in case of the norms' collision the Convention has a priority [...].

In the decision of 27 December 2004 the Court of Appeal of Lithuania (the Rapporteur judge A. Kruopys) analysed a question concerning the applicant's right to consult the case - file (criminal case). The Court of Appeal relying on the jurisprudence of the European Court of Human Rights (case Lamy v. Belgium, judgment of 30 March 1989) in application of $\S 4$ Article 5 of the Convention, acknowledged in substance that the applicant's right to challenge his remand in custody had been breached. The Court also afforded some redress in that it quashed the decision of the Vilnius Regional Court of 30 November 2004.

Of the crucial importance for the effectiveness of the Lithuanian legal system from the Convention perspectives is one of the newest Decision of the European Court of Human Rights in the case Savickas v. Lithuania and other 5 applications (no. 663565/09, decision on admissibility of 15 October 2013). The Court observed finally, taking also into account the positive practice of the Lithuanian courts in interpreting Article 6.272 of the Civil Code in the light of the requirements of Article $6 \S 1$ of the Convention (length cases), that this remedy can be regarded as an effective remedy addressing the length of proceedings problems in a proper and effective way at national level. The Court also observed the fact that the authorities did not limit themselves to compensatory remedies alone - legislative amendments aimed at expediting civil proceedings have also been introduced - therefore a combination of two types of remedies, one designed to expedite the proceedings and the other to afford compensation, seems to be the best solution for the redress of breaches of the "reasonable time" requirement (see Grzinčič v. Slovenia, no. 26867/02, § 96, 3 May 2007). What is of the crucial importance in this Decision that the Court decided that this new domestic remedy can be regarded as effective one relying on the judicial interpretation of 6 February 2007, when the Supreme Court of Lithuania affirmed that the aforementioned provision (Article 6.272 of the Civil Code) should be applicable when assessing the damage for the length of proceedings problems.

In the mentioned case no. 3K-7-7/2007 of 6 February 2007, the Supreme Court examined a civil claim for pecuniary and non-pecuniary damage lodged by a claimant whose criminal proceedings had lasted some six years at one level of jurisdiction. The Supreme Court thus considered that the pre-trial investigation authorities had not acted with sufficient diligence, thereby breaching the claimant's right to timely criminal proceedings. Having the status of a person charged with a crime, the claimant had experienced uncertainty about the end of the criminal proceedings. Moreover, this procedural status had for an unjustifiably long time limited her other rights: the right to move (she was under an obligation not to leave her place of residence) and her property rights (her property had been seized). Taking into account also the fact that the delayed criminal investigation and the restrictions applied to the claimant had caused her emotional distress, tarnished her reputation and restricted her opportunities for contact with others, and the fact that the claimant, who had two minor children, had been without income for a long time, the Supreme Court considered that a sum 
of LTL 15,000 (approximately 4,300 euros (EUR)) would be appropriate to compensate for nonpecuniary damage. It also awarded the claimant LTL 15,000 for pecuniary damage.

The European Court of Human Rights regarded this Decision of the Supreme Court as a starting point in recognizing the existence of the effective remedy as regards the all types of the judicial proceedings at domestic level. Now all the applicants complaining to Strasbourg about the length of judicial proceedings in Lithuania must exhaust the domestic remedy provided in Article 6.272 of the Civil Code.

It should also be remembered that already in the case Giedrikas v. Lithuania ((dec.), no. 51392/07, 14 December 2010) it found, "having regard to the particular circumstances of the case" that the applicant, who had received LTL 8,000 in compensation for non-pecuniary damage, could no longer be considered a "victim" within the meaning of Article 34 of the Convention. In another case Beržinis v. Lithuania ((dec.), no. 20513/08, 13 December 2011) (the applicant had contributed substantially to the delay in the proceedings), the Court held that the sum of EUR 290 awarded to the applicant could be considered sufficient and therefore appropriate redress for the violation found. In the third case on this point - Jonika v. Lithuania ((dec.), no. 25991/05, 20 November 2012), the Court held that the sum awarded to the applicant (EUR 2,900) "almost correspond[ed] to the sum that the Court would be likely to have granted in accordance with its practice". However as it appeared that these three cases were rather specific and were determined on their particular facts. The Court therefore had not found the effective remedy's existence in Lithuania in the mentioned 3 cases. This happened after some time in the above mentioned case Savickas v. Lithuania and other 5 applications $^{285}$ in 2013 which can be regarded as a crucial achievement of the Lithuanian judiciary.

Administrative courts of Lithuania apply directly the provisions of the European Convention in their practice as well. It's extremely important to note the pioneer decision of the Supreme Administrative Court of Lithuania of 29 November 2010286, where the Court awarded the nonmaterial damage to the person who was deprived of the right to change his gender in Lithuania, taking into account the legal vacuum, as established in the case L. v. Lithuania ${ }^{287}$, where the European Court of Human Rights found a violation of Article 8 of the Convention and obliged Lithuania to adopt the special law on conditions and procedure for the gender re-assignment surgery. The Court stated that the respondent State, in order to satisfy the applicant's claim for pecuniary damage, is to pass the required subsidiary legislation to Article 2.27 of its Civil Code on gender reassignment of transsexuals, within three months of the present judgment becoming final. Alternatively, should those legislative measures prove impossible to adopt [...], the respondent State is to pay the applicant EUR 40,000 in respect of pecuniary damage ${ }^{288}$. The law was not adopted during the mentioned period, therefore the Lithuanian Government while executing the judgment opted for the second alternative and paid the applicant 40,000 EUR.

Following the outcomes of this case, the administrative courts of Lithuania have started to receive claims for compensation from people who had changed their gender in the foreign countries. The

285 Savickas v. Lithuania and other 5 applications (no. 663565/09, Decision on admissibility of 15 October 2013).

${ }^{286}$ Administrative case No. A(858)-1452/2010, judgment of the Supreme Administrative Court of 29 November 2010, Reporting judge I. Jarukaitis.

287 L. v. Lithuania, no.27527/03, judgment of 11 September 2007.

288 Some Discussions were going on in Lithuania, as regards the legitimacy of the Court's requirement imposed on the State to adopt some legislative measures, whether it is not in confrontation with the subsidiary character of the Convention. See also the Dissenting Opinion of Judge Fura-Sandström added to the case, where she expressed her concern that, by adopting such a solution, the Court risks acting ultra vires. The Convention clearly sets out a division of competences. Under Article 41 of the Convention, it falls to the Court, when a violation of the Convention or its Protocols has been found, and if the internal law of the High Contracting Party concerned allows only partial reparation to be made, to afford just satisfaction to the injured party, if necessary [...]. 
Supreme Administrative Court following and directly relying on the judgment in L. v. Lithuania case awarded the applicant R. S. 30000 LT for non-pecuniary damage. This domestic decision of the administrative court is very important, showing a direct effect of the judgments of the European Court of Human Rights at national level. Such direct reliance by the national courts on the Strasbourg Court's cases should be the most welcome.

In the decision of the Supreme Administrative Court of Lithuania of 19 May 2006 (the Administrative case No. N(16) - $1274-06$ (Category of procedural decision 3.5) the Court (the Rapporteur judge V. Urmonaite) relying on Article $5 \S 1 \mathrm{f}$ decided to abolished a decision of the lower court to prolong the application of the applicant's detention which had already been continuing for 21 months due to the facts that such lengthy detention for the deportation purposes was neither proportionate nor justified under the circumstances of the case. In this particular case the applicant was allowed to live further in the Foreigners' Registration Centre, however, any more restrictions on his freedom of movement were imposed.

In the administrative case No. $\mathrm{AS}^{822}-339 / 2010$, the Supreme Administrative Court in its decision of 7 May 2010 relied directly on the Court's jurisprudence and decided that the gay demonstration could take place in Vilnius as planned ${ }^{289}$. Relying on the Strasbourg Court's case Bqczkowski and Others v. Poland (Appl. No. 1543/06, judgment of 3 May 2007), where the Strasbourg Court found a violation of Article 11 of the Convention, the Supreme Administrative Court decided that no documents or other evidences had been presented to the court showing the negative impact of the demonstration on the public safety; therefore there was no need to protect the public order ${ }^{290}$.

The use of the secret documents as evidence in the administrative cases was already discussed ${ }^{291}$. Taking into account the violations of Article 6 found in the Lithuanian cases in Strasbourg, the Supreme Administrative Court in its decision of 8 October 2009 in the administrative case No. A(822)-326/2009 decided that from the jurisprudence of the European Court of Human Rights it is quite clear that factual data which constitutes a State or official secret being the sole or the most important evidence in the case may not be used as evidence in an administrative case until it has been declassified. Such positive tendencies in the jurisprudence of the administrative courts concerning the use of evidence are of significant importance. The question only arises why the Court's principles had not been applied by domestic administrative courts while analysing the above mentioned Užukauskas, Pocius or some other cases ${ }^{292}$.

Furthermore, in the decision of 21 December 2009 the Vilnius Regional court ${ }^{293}$ analysing the question concerning the Vilnius City municipality acts and their obligation to take some measures, decided that a person is not obliged in every case to follow the special non-judicial procedure, especially when the use of such procedure is a very formal one. The court decided that too complicated and bureaucratic procedure for the restitution of property rights could deny the individual's right to the effective judicial control and its accessibility under Article 6 of the Convention, as well as Article 30 of the Lithuanian Constitution [...].

289 Administrative case No. AS ${ }^{822}-339 / 2010$, decision of the Supreme Administrative Court of 7 May 2010, Judges Piličiauskas and Jarukaitis, Reporting judge Sk. Žalimienè.

290 The Author indicates also another case in this field - Alekseyev v. Russia, (Appl. Nos. 4616/07, 25924/08 and 14599/09, §§ 84-88, 109-110), judgment of 21 October 2010), where the violation of article 14 in conjunction with Article 11 was found, for the reason that the gay parades were constantly forbidden and not allowed in Moscow. The Court established that the applicant suffered discrimination on the grounds of his sexual orientation. It considered that the Government did not provide any justification showing that the impugned distinction was compatible with the standards of the Convention.

291 See Footnotes nos. 42-46.

292 See Footnotes nos. 44, 45.

293 Administrative case No. 1-366-602/2009, decision of 21 December 2009, Reporting judge V. Ruskan, approved by the Supreme Administrative Court on 2 November 2010, administrative case No. A(858)$1652 / 2010$. 
Yet another interesting example comes again from the jurisprudence of the Supreme Administrative Court of Lithuania - from the administrative case No. A (858) - 940/2010, Decision of 23 June 2010), where the applicant argued that the proceedings before the Supreme Administrative Court were too lengthy (approx. 12 months) as regards his request to compensate the material and moral damage which the applicant had suffered during the time period of 12 months when he was deprived of his driving licences. The mentioned Court stressing the fact that the Convention forms part of the Lithuanian legal system, stated the obligation to all administrative courts to apply directly the Convention in the administrative cases. The Court relying on the Strasbourg court's jurisprudence, and especially on the case Hentrich v. France (Appl. No. 13616/88, judgment of 22 September 1994, $\S 61$, viol. of Art. $6, \S 1$ ) and as well, on the Lithuanian case UAB Impar v. Lithuania (Appl. No. 13102/04, judgment of 5 January 2011, § 28) rejected the applicant's claim concerning the excessive length of the administrative proceeding, as the length in that administrative case could not be regarded as excessive.

This decision of the Supreme Administrative Court is very innovatory and significant. The administrative courts were invited to apply directly the Convention at national level and, what is the most important, to rely directly on the Court's jurisprudence. In the Author's opinion, such legal way of the interpretation and direct application of the Convention by the domestic courts at the national level is the most welcome. It strengthens the subsidiary character of the Convention system and demonstrates clearly an interaction between the domestic courts and the Strasbourg Court.

The mentioned cases showing the direct application of the European Convention on Human Rights in criminal ${ }^{294}$, civil and administrative cases, demonstrate clearly the importance of the Convention at national level. It means that Lithuanian judges are capable and fully equipped to follow and apply the Convention's "minimum standards" at home. Moreover, during the 18 years of the application of the Convention in Lithuania, a very important legal step forward can be seen if to compare the legal system now with the old legal system which had existed before 1995. The Convention is directly applied by national courts, the applicants have a possibility to raise the alleged violations of the Convention rights already before the domestic courts. Even more, in some cases the Lithuanian judges are directly relying on the judgments of the Court when solving the cases.

Another important legal step forward - the deprivation of liberty and its guarantees under Article 5 of the Convention. Now only the judge/court can sanction the detention on remand or its prolongation. So many changes in the legislation have been made in order to comply with this standard of the Convention. Furthermore, the Judiciary of Lithuania is also organised according to the principle of a fair trial and judicial independence under the requirements of Article 6 of the Convention.

The final Conclusion - the Convention has become "a successful story for Lithuania" speaking in the words of Mr. L. Wildhaber, former President of the European Court. Lithuanian courts can in general be regarded as being innovatory, relying directly not only on the Convention provisions but also on the Court's case -law (especially referring to the judgments adopted by the Strasbourg Court in the cases against Lithuania).

Such legal way of the interpretation and direct application of the Convention by domestic courts strengthens clearly the subsidiary character of the Convention system and demonstrates close cooperation between the domestic courts and the Strasbourg Court; such interaction and co-operation is one of the core principles stated in the Interlaken Declaration adopted by the Interstate Conference on 19 February $2010^{295}$.

294 The Constitutional Court of Lithuania in its Conclusion of 24 January 2005 expressed an opinion that the Convention cannot be directly applied in the criminal cases, but the Lithuanian courts have demonstrated an opposite movement and applied directly the Convention in the criminal cases as well, Op. cit. (Footnote 16).

295 The text of the Declaration, see:

http://www.eda.admin.ch/etc/medialib/downloads/edazen/topics/europa/euroc.Par.0133.File.tmp/final_en.p 


\section{Conclusions}

A clear tendency can be seen from the Lithuanian cases which have been lost in Strasbourg during 18 years of the Convention's application in Lithuania - the Lithuanian cases in Strasbourg are becoming more legally complicated, raising different aspects of the rights and guarantees enshrined in the Convention.

The first Lithuanian cases, in principle, were related exceptionally to the detention on remand problems and procedural guarantees under Articles 5 and 6 of the Convention. Subsequently, very interesting legal aspects from the jurisprudential point of you had been raised in the Lithuanian cases: freedom of expression and responsibility of the Press for violation of private life (relationship between Articles 8 and 10 of the Convention), the inability to undergo full gender reassignment surgery in view of lack of a law specifying the conditions and procedure for such surgery (Articles 2 , 3,8 and 12), legality of the use of the secret investigation methods and fulfilment of fair trial guarantees under Article 6, confiscation of property of the dead person (Article 6 and Article 1 of the Protocol 1), granting custody rights towards two small sisters (Article 8 of the Convention), definition of genocide and legality of the conviction (Article 7), State's positive obligation to protect imprisoned people from the violence of another prisoners (Article 2 and 3), domestic violence issues and the State's positive obligation therein ${ }^{296}$, Impeached State President's right to participate in the parliamentary elections, etc.

Another clear tendency is that the Lithuanian national courts after good experience of 18 years are fully capable to apply correctly the Convention and the case law of the Court in their practice. This is very important aspect to ensure the subsidiarity character of the Convention system and to ensure the margin of appreciation principle left to the States. Evaluation of the facts and evidences by national courts are in principle followed by the Strasbourg Court; the re-evaluation can be made by the European Court in exceptional cases only, when the Convention principle are/or can be violated. The same classical approach can be found in many Lithuanian cases (see Tautkus v. Lithuania, appl. No. 29474/09, judgment of 27 November 2012, No viol. of Art. 3; see also Kuolelis and Others v. Lithuania, appl. No. 74357/01 and others, judgment of 19 February 2008, No viol. of Art. 6, 7, 9, 10 and 14; Borisov v. Lithuania, appl. No. 9958/04, judgment of 14 June 2011, striking out as the matter under Art. 8 resolved; etc.).

Furthermore, many legal amendments in the laws of Lithuania in all spheres and adoption of the new Criminal, Criminal Procedure, Civil and Civil Procedure Codes after 2000 were very important legal steps in order to guarantee the Convention standards at national level. In the legislation process every draft of law must always be evaluated under the requirements of the Convention and the Court's case law, as well as under the European Union law. The legal evaluation of the mentioned compatibility is obligatory at national level and should be done for every draft of law.

Further, an important aspect was the creation in 1999 of the new administrative courts of Lithuania. They have their legal and practical recognition by the whole judiciary. Already in 2003, the European Court of Human Rights took a note of the significant legal development of the practice of the Lithuanian administrative courts and recognised them as an effective domestic remedy under Article 13 of the European Convention on Human Rights in the field of administrative relations, which must be used at domestic level before applying to Strasbourg.

It should also be mentioned that the teaching of the Convention has been introduced to many teaching programs in Lithuania: two main Law Universities/Faculties (Vilnius University Faculty of Law and Mykolas Romeris University Faculty of Law) have many teaching programmes related to the Convention and Court matters; students have been studying the jurisprudence of the Court, the

df

296 Cases Tautkus v. Lithuania, appl. No. 29474/09, judgment of 27 November 2012, No viol. of Art. 3; Valiulienè v. Lithuania, appl. No. 33234/07, judgment of 26 March 2013, viol. of Art. 3. 
Moot court competitions have been organized, etc. The Convention and the Court's case-law has been tought and analysed under the Judges' and civil servants' qualification programmes, many visits of judges, prosecutors, policemen, students were organized to the European Court of Human Rights. Such important legal activities have helped a lot to increase the awareness about the Court's system which can especially be seen from the Lithuanian courts activities and their activeness in applying the Convention standards at domestic level.

Lastly, the biggest legal problem of Lithuania which has been experienced in Strasbourgreasonableness of the length of proceedings under Article 6 para. 1 - has been solved at domestic level by the Supreme Court of Lithuania and the Strasbourg Court took finally note of this important legal development. The ECHR decided that Lithuania has finally an effective domestic remedy for the length of proceedings cases. In the case Savickas v. Lithuania and other 5 applications (no. $663565 / 09$, decision on admissibility of 15 October 2013) the Court observed that taking also into account the positive practice of the Lithuanian courts in interpreting Article 6.272 of the Civil Code in the light of the requirements of Article $6 \S 1$ of the Convention and especially the Decision of the Supreme Court of Lithuania of 7 February 2007, this remedy (a possibility to submit the compensation claim under the Civil Code) can be regarded as an effective remedy addressing and solving the length of proceedings problem in Lithuania. 


\title{
REPUBLIC OF MACEDONIA
}

\author{
Mirjana Lazarova-Trajkovska* \\ The Impact of the ECHR and the case law on the Republic of \\ Macedonia
}

\section{Introduction}

This chapter presents our findings concerning the effects of the ECHR and the case law of the European Court of Human Rights on some of the key pillars of democratisation in the Republic of Macedonia. Within the general framework of the book, "the effects" are analysed through the legislative, institutional and other changes, which have been introduced in the country because of its policy of domestication (ratification, application and interpretation) of the norms and principles of the ECHR and its court's case law.

Theoretically, "the effects" are understood as the power of one specific international system, the one established by the ECHR, to influence changes in the national or more specifically the Macedonian - legal system for protection of human rights through its democratic political system. Such influences are identified in the specific rational (normative and political) behind various legislative, institutional or educative initiatives and projects introduced by relevant national actors. The specificity of this rational is formulated usually as "harmonisation" of the national system with the respective European international system. In this particular case, we are dealing with the process of harmonisation of the national system of the Republic of Macedonia with the European Convention of Human Rights. This process could be interpreted in a narrower sense, as "conventionisation process", and in a broader sense, as "Europeanisation process" 297 . In both cases, harmonisation reads acceptance and institutionalization within the Macedonian national system of the so-called European democratic and human rights values and standards - established by the ECHR and its Court in Strasbourg.

The time span of the analysis extends from the time of signature of the Convention (1995) until the present day. Within less than two decades, we can distinguish two phases in terms of the scope and the character of the recognized effects. The first period extends from around the signature of the ECHR until the first violation judgments of the Court for the Republic of Macedonia. Within this period of about ten years, the effects of the ECHR are more of a legislative and institutional nature and, as such, they have a larger scope of influence on the democratic processes. Within the second period, the effects are more of a piecemeal character and institutionally localized mainly within the judicial system.

One could also say that the effects of the ECHR and the Court's case law in these two periods had two different paths. In the first period, they initially affected the political actors and institutions undertaking legislative initiatives and further institutional changes towards the rule of law, separation of powers and particularly the independence of judicial power. In the second period, it is the other way around. The case law affected primarily the national judicial system, and then via its

\footnotetext{
${ }^{297}$ Although the term "Europeanization" is usually used within the European Union studies and refers, first of all, to the EU's impact on its member states and on association states, its use in the context of our analyses of the effect of the ECHR upon the countries of South East Europe is legitimized by the fact that, the public opinion in Macedonia, for example, considers the Council of Europe and its instruments and institutions such as the ECHR and the Court as the threshold of Europe. In a similar way, the protection of human rights was understood just another term for democracy.
} 
interpretations and further actions of its agents, affected the government and through it, the other branches of the political system.

In what follows we will focus firstly, on the effects of the ECHR during the accession decade. Its main institutional and legislative effects are presented through the positioning of the Convention in the national hierarchy of norms, and its status in domestic law. Secondly, we will present legislative reforms, which resulted directly from the judgments on the Republic of Macedonia or indirectly from the implementation of the principle res interpretata. Our aim is to present how the most important judgments on the Republic of Macedonia have influenced national case law and practice. We will also look into the practice of the courts in the Republic of Macedonia and their reference to the Court's case law.

\section{The effects of the Accession to the ECHR}

The accession of the Republic of Macedonia to the ECHR was achieved in a relatively short period. It signed the Convention in November 1995 and ratified it in April 1997. Yet, the process of harmonisation of its constitutional system with the standards of the Convention had started few years before the signature. In a way, the ECHR had influenced the democratic development in the country even before its formal membership to the CoE and its accession to the Convention. "The Republic of Macedonia undertook ...harmonisation of the legal order with the European Convention as early as the adoption of the Constitution ... in 1991. As a result of this, a large number of the ideas contained in the European Convention had been previously integrated in this constitutional act, as well as in other more significant laws passed by the Assembly ... in the period from 1992 to 1995 (the 1992 Law on Defense, the 1994 Law on Political Parties, the Internal Affairs Law, the Law on Courts and the Law on Local Self-Government in 1995)". 298

The democratic forces which in 1990 won the democratic elections, began the long and today not yet finished march towards establishing the Republic of Macedonia as a member state of the world polity, and in the first instance, of the "European family" of states. Based on their pro-European ideological convictions they took "the political legitimacy of the Convention ... for granted." In this way, as it was the case in some "other late-ratifying States"... "the Convention offered an established, 'external', and therefore legitimate, normative standard for the transition to constitutional democracy..." This perspective on the role of the Convention in the democratization process, developed by Helen Keller and Alec Stone Sweet allows us to conclude that the accession and ratification which followed later "served, in effect, to certify the membership" of the Republic of Macedonia in "the circle of good European countries." 299

Yet, there were many things to be done in order to build a domestic system for the protection of human rights which would be in harmony with the Convention and the case law. After signing the Convention, the Government established an inter-ministerial expert group with the task of analyzing the compatibility of the in that time existent legal order of the Republic with the standards and requirements of the ECHR and to propose required measures. The result of the work of this expert group was a compendium of recommendations for legislative changes in a number of laws before the ratification of the Convention.

The ratification ${ }^{300}$ was not subject to public criticism, but on the contrary the media reported a number of welcoming comments made by human rights defenders, scholars and analysts. The

\footnotetext{
298 Skaric S. and C. Cvetkovski, "Contemporary Constitutional Issues and Debates in the Republic of Macedonia: Macedonian Constitutional System in the Light of the European Convention on Human Rights" http://www.cecl.gr/RigasNetwork/databank/REPORTS/r3/Fy_3_Cvetkovski.html accessed 13/04/2013.

299 Sweet, A. Stone and Helen Keller, "Assessing the Impact of the ECHR on National Legal Systems" (2008). Faculty Scholarship Series. Paper 88. http://digitalcommons.law.yale.edu/fss_papers/88 accessed 28/05/2013 pg. 678-679.

300 Law on ratification of the Convention was published in the "Official Gazette of the Republic of Macedonia"
} 
ratification was considered as confirmation of declared politics of democratization and rule of law through building an internationally verified domestic human rights protection system. Within that context, the most discussed issue concerning the effects of ratification on the national political system was the place and the status of the Convention in the hierarchy of the domestic legal system. The solution established was in line with the monist traditions of the international law.

According to the Constitution, "the international agreements ratified in accordance with the Constitution are part of the internal legal order and cannot be changed by law." 301 On these grounds, the direct effect of the ECHR as an international human rights treaty over national legislation was established. ${ }^{302}$ As is the case with all international treaties ratified by the Republic of Macedonia, the Convention became part of the domestic legal order. In the normative order of the Macedonian legal system, the Convention was positioned between the Constitution and the laws. The Constitution is the highest in the hierarchy of legal acts. This means that all acts (laws, statutes) must be in conformity with the Constitution. ${ }^{303}$ Within this normative framework, incorporation of the Convention and its case law into the national law and practice was seen as the most effective way of its implementation into Macedonian legal order. ${ }^{304}$

\section{The Effects of the Court's Case law}

Our analyse of the effects of the Court's case law on the Republic of Macedonia led us to the conclusion that the influences are first of all conditioned by the Court's treatment of Macedonian cases. Certainly, the Court's case law in general has also certain influences but they are rather indirect, less visible and weaker than the national cases handled by the Court. The case law of the Court in Strasbourg was not of a specific relevance for the work of Macedonian courts before, during and soon after ratification of the Convention. National courts were almost exclusively referring to the Constitution as the highest legal source concerning human rights violations. The case law of the Court in Strasbourg concerning other countries parties to the Convention became relevant and influential on Macedonian courts only after and in a relation to national cases brought before the Court. From this perspective, in what follows we will present the effects of the most important Court's judgments concerning the Republic of Macedonia.

First, we present the main structural characteristics of Macedonian cases dealt with by the Court. In this way we highlight the possible effects of the Court's case law on the country. Then, in the second section we respond to the question whether and how the Court's judgments had influenced first of all the national judiciary and through it the legal and political subsystems. In this way we emphasise the role of the national judges in the implementation of the Convention and its standards, since, even a perfect legislation without proper implementation by the national courts will result in a violation of the Convention.

\subsection{The Macedonian human rights dossier at the ECHR}

Macedonian case law ${ }^{305}$ before the Court has evolved slowly, compared with other countries. Especially in terms of its size, the quality of applications, their structure, in terms of the different

no. $11 / 97$

301 Article 118 of the Constitution of the Republic of Macedonia

302 Polakiewicz Jorg (2001) "The Status of the Convention in National Law" in Fundamental rights in Europe : the European Convention on Human Rights and its Member States, 1950-2000, Blackburn, Robert (ed.) Oxford University Press, 2001 (pg.32)

${ }^{303}$ Constitution of the Republic of Macedonia, Article 51

304 "Incorporation is the most faithful way of implementing the Convention into domestic law" Polakiewicz Jorg (2001)"The Status of the Convention in National Law" in Blackburn Robert and Jorg Polakiewicz (eds.) Fundamental rights in Europe : the European Convention on Human Rights and its Member States, 1950-2000, Oxford University Press, 2001,(pg.35). 
alleged human rights violations (different articles of the Convention) as well as in terms of the type of the Court's treatment (decisions, friendly settlements, violation or non-violation judgments etc.) and in terms of their effects on the human rights situation in the country.

The first judgment on the Republic of Macedonia was delivered in 2001, almost four years after the ratification of the Convention. ${ }^{306}$ One year later in 2002, in the second judgment on Republic of Macedonia (Janeva complained about the length and fairness of a set of civil proceedings) the case was a strike out of the list of cases as a result of friendly settlement between the applicant and the State. ${ }^{307}$ In 2003 and 2004, there were no judgments and decisions on the Republic of Macedonia.

Later, in 2005, almost seven years after the ratification of the Convention, the first two violation judgments were delivered. In the cases of Djidrovski and Veselinski, the applicants alleged a violation of their property rights (as a former army serviceman's, right to purchase an apartment with a price adjustment) under Article 1 of Protocol No. 1 to the Convention. In addition, they alleged that they had been discriminated against in comparison to other army servicemen who had purchased the apartments at a reduced price. In two separate judgments, the Court had decided that there had been a violation of Art. 1 of Protocol No. 1 and that it was not necessary to examine whether there was a violation of Art. 14 of the Convention in conjunction with Art. 1 of Protocol No. 1. ${ }^{308}$

By the end of 2005, the Court delivered two judgments on the length of proceedings. The first judgment was in case of Dumanovski were the Court decided that there has been a violation of Article $6 \S 1$ of the Convention concerning length of proceedings and the applicant's claim on just satisfaction was dismissed. ${ }^{309}$ In the case of Atanasovic and others, applicants were complaining on

305 The total number of submitted applications from 1998 until 1 January 2013, concerning Republic of Macedonia is 3718. At the time of writing this document (February 2013) the database of the Court included 92 judgments, 198 friendly settlement decisions, 43 unilateral declarations and 50 inadmissibility decisions (decided by Chamber of seven judges). One case (El-Masri) was decided by Grand Chamber judgment.

In the first ten years (1998-2008) 1618 application were submitted to the Court, out of whom 365 applications were decided as inadmissible and 31 judgments were established. In two cases (Janeva app. 58185/00 and Kozarov app. 64229/01) the Court by judgment has strike out these applications as a result of friendly settlement, and in one case (Solakov 47023/99) the outcome was judgment finding no violation. By the rest of the applications, the Court has found violations. The overall impression for first ten years on Macedonia is that in this phase only $24.4 \%$ (or 396 out of 1618 ) applications of the total number of applications were decided.

The situation has changed in last the five years. Namely, from January 2008 until January 2013, new 2100 applications were submitted. This, with the backlog of undecided 1222 cases from previous ten years, means that in the last five years the Court faced 3322 cases. In past five years, 2218 cases were decided with inadmissibility decisions, 198 with friendly settlement, 43 with unilateral decision and 61 with judgments. This means that in last five years $13,2 \%$ of the cases has been ended with violation, friendly settlement or unilateral declaration and $86,8 \%$ are decided with inadmissibility decision.

306 Solakov (Application no. 47023/99) judgment of 31.10. 2001. The applicant alleged that his trial was unfair in that he had been unable to cross-examine the witnesses whose statements served as the only basis for his conviction and to obtain the attendance and examination of two witnesses for the defence. The Court decided that there has been no violation of Article $6 \quad \S \S \quad 1$ and 3 (d) of the Convention. (http://hudoc.echr.coe.int/sites/eng/Pages/search.aspx\#\{“fulltext":["Solakov"],"documentcollectionid":["COM MITTEE","DECISIONS", "COMMUNICATEDCASES","CLIN", "ADVISORYOPINIONS", "REPORTS", "RESOLUTIONS"],"it emid":[“001-59869"]\}last access:13.03.2013)

307 Janeva (Application no. 58185/00) judgment (Friendly settlement) of 3 October 2002 (http://hudoc.echr.coe.int/sites/eng/pages/search.aspx?i=001-60663)

308 Djidrovski (Application no. 46447/99) judgment of 24 February 2005 and Veselinski (Application no.

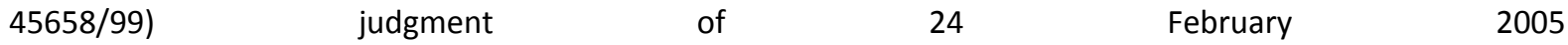
(http://hudoc.echr.coe.int/sites/eng/Pages/search.aspx\#\{“fulltext":[“djidrovski”],"documentcollectionid":[“GR ANDCHAMBER","COMMITTEE", "DECISIONS","COMMUNICATEDCASES","CLIN","ADVISORYOPINIONS","REPORT $S^{\prime \prime, " R E S O L U T I O N S "]\} l a s t ~ a c c e s s ~ o n ~ 13.02 .2013 ~}$

309 Dumanovski (Application no. 13886/02) judgment of 8 December 2005 (http://hudoc.echr.coe.int/sites/eng/Pages/search.aspx\#\{“fulltext":[“Dumanovski”],"documentcollectionid”:[“ 
length of proceedings but also on the lack of domestic remedies. The Court decided unanimously the complaints concerning the excessive length of proceedings and the lack of remedies, in that respect admissible, but by six votes to one that there had been a violation of Article $6 \S 1$ of the Convention concerning length of the proceeding and unanimously that there has been a violation of Article 13 of the Convention. The applicants claim for just satisfaction was unanimously dismissed. This was the second judgment on length of proceedings but the first judgment where the Court clearly had found a violation concerning lack of legal remedy on length of proceedings. ${ }^{310}$ These two judgments disclosed one of the most serious problems of the human rights protection system in the country. The growing number of cases concerning the length of proceedings ${ }^{311}$ in 2008 initiated significant legislative and judiciary changes aimed at strengthening the various elements of the rule of law in respect to the issue of length of proceedings.

In 2007, the Court delivered four judgments on other aspects on Article 6 and with one judgment finding violation on Article 3. In two cases, the issue was equality of arms, ${ }^{312}$ in one case it was the issue of unfair trial concerning the applicant's inability to be present at the hearing, ${ }^{313}$ and in one case the trial was unfair concerning the impartiality of the trial judge..$^{314}$

The same year the Court delivered a judgement on violation of Article 3 of the Convention on account of the failure of the authorities to conduct an effective investigation into the applicant's allegations that he was ill-treated by the police ${ }^{315}$. This case will be analysed again in the chapter focussing on the most important cases in the Republic of Macedonia. Here, we would like to emphasise that this was the first case on alleged police brutality and failure to conduct an effective investigation and it was in some way an announcement of the new types of cases that were coming from the country. This judgement was followed by three new judgments concerning Article 3 of the Convention because of the failure of the authorities to conduct an effective investigation into the applicant's allegations that they were ill-treated by the police. ${ }^{316}$ They would later on have an impact on the appropriate changes in the new Code on Criminal Procedure.

Starting from 2008, Macedonian cases were enriched with judgments that today are part of the Court's case law. For example, in one case the reason for finding a violation was violation of Article 6 of the Convention in respect of the applicant's right of access to court and to have his case heard within a reasonable time. ${ }^{317}$ In another case, a violation was found as a result of the fact that the Supreme Court's decision had been suspended and not enforced and that the applicant had not had an effective remedy against its non-enforcement. ${ }^{318}$ In the case of Jankulovski, the Court has found a violation because of the fact that the State violated the applicant's "right to a court" and failed to comply with the obligation to secure to the applicant the effective enjoyment of his right of property as established by the court decisions. ${ }^{319}$ The rest of the nine judgments for 2008 were on length of

COMMITTEE","DECISIONS","COMMUNICATEDCASES","CLIN","ADVISORYOPINIONS","REPORTS","RESOLUTION $\left.S^{\prime \prime}\right]$, ,itemid":[“001-71558"]\}) last access 13.03.2013

310 Atanasovic and others (Application no. 13886/02) judgment of 22 December 2005 (http://hudoc.echr.coe.int/sites/eng/pages/search.aspx?i=001-71813 last access 13.03.2013)

${ }^{311}$ During the 2006, the Court delivered seven violation and one no violation judgments. All seven judgments were on length of proceedings. In case of Milošević the Court has found violation on length of proceedings and for the first time in judgment on Republic of Macedonia, non-pecuniary damage was established.

312 Stoimenov,( application no. 17995/02) judgment of 5 April 2007 and Grozdanoski (application no. 21510/03) judgment of 31 May 2007

313 Mitrevski,( application no. 33046/02) judgment of 21 June 2007

${ }^{314}$ Nikolov (application no. 41195/02) judgment of 20 December 2007

315 Jasar ( application no. 69908/01) judgment of 15 May 2007

316 Trajkoski (application no. 13191/02) judgment of 07 February 2008; Dzeladinov (application no. 13252/02)

judgment of 10 April 2008; and Sulejmanov ( application no. 69875/01 judgment of 24 April 2008

317 Fetaovski (application no. 10649/03) judgment of 19 June 2008

${ }^{318}$ Nesevski (application no. 14438/03) judgment of 24 April 2008

319 Jankulovski ( application no. 6906/03) judgment of 03 July 2008 
proceedings, but one of them deserves special attention. In the case of Parisov the Court has clearly stressed that legal remedy that was prescribed by domestic legislation is not in line with the Court's standards on effective legal remedies. The year 2009 was marked by four important judgments. In the case of Radko and Paunkovski, the Court found that Article 11 was violated. ${ }^{320}$ In the case of Bočvarska, the Court found that the enforcement proceeding was in breach of the principle of the rule of law inherent to the Convention, and a violation was established on Art. 1 Protocol No. ${ }^{3.21}$ In the cases Stojanovski and Lazoroski versus the Republic of Macedonia, the Court established violation(s) on different aspects of Article 5 for the first time..$^{322}$

Among other cases, in 2010, the judgment on Vasilkovski and others was the most remarkable one. Namely, the Court found a violation of Article $5 \S 3$ of the Convention based on the fact that the national courts did not provided sufficient reasons for the applicants' continued detention. ${ }^{323}$ In the same year out of fifteen judgments in nine of the cases length of proceedings were grounds for finding a violation. In this respect, the Court found that it was still too early to deliver a judgment on the effects of the new legal remedy introduced by the amendments to the Court's Act in 2008. This was the reason why in the case of Surbanoska and others the Court declared the application inadmissible finding that applicants, who meanwhile used the length remedy successfully, could no longer claim to have victim status, but at the same time, the main message was that it is too early to say that the legal remedy in general is effective. ${ }^{324}$

Then in 2011 in the case of Adzi-Spirkoska and others the Court found that a length of remedy introduced in 2008 could be regarded effective ex nunc. ${ }^{325}$ Because of this case, friendly settlements and unilateral declarations were introduced in 241 cases. At the time of writing this article, the Court is dealing with over 300 cases that were submitted before Adzi-Spirkoska case. Most of them will end with friendly settlements or by unilateral declaration. In this year, one of the most important cases was the case on Atanasov. This case concerns violation of the principle of equality of arms. ${ }^{326}$

In 2012, eight judgments were established on the Republic of Macedonia, and three of them are of special importance concerning the case law of the Court and Macedonian case law. In the case of Sašo Georgiev, the Court found a violation of Article 2 of the Convention in its substantive aspect in that the State was to be considered responsible for unlawful actions of its agent taken outside his official duties. ${ }^{327}$ Then in the case of Gorgi Georgiev the Court found that the State did not discharge its procedural obligation under Article 3 of the Convention. ${ }^{328}$ Perhaps one of the most remarkable judgments in 2012 on the Republic of Macedonia but also at Court level in general, is the Grand Chamber judgment in the case of El-Masri. ${ }^{329}$

\footnotetext{
${ }^{320}$ Association of Citizens Radko and Paunkovski (application no. 74651/01, 15 January 2009)

${ }^{321}$ The quashing of a final decision given in enforcement proceedings conferring on the applicant the right to inherit the established claims of an undertaking, which was run and owned by the applicant at the relevant time. The quashing was upon the intervention of the public prosecutor, who was not a party to the proceedings. Bočvarska (no. 27865/02, 17 September 2009).

322 Lazoroski (no. 4922/04, 8 October 2009, violation of Article $5 \S 1$ (c), violation of Article $5 \S 2$ and violation of Article $6 \S 1$ ). In case of Stojanovski (no. 1431/03, 22 October 2009), violation on Article $5 \S 1$ (e) was founded.

${ }^{323}$ Vasilkovski (no. 28169/08)

324 Surbanoska and others, (no. 36665/03) was considered as leading case regarding the effectiveness of a length remedy introduced in 2008.

${ }^{325}$ Adzi-Spirkovska and others (no. 38914/05) and Topuzovski (no. 17879/05)

${ }^{326}$ Atanasov (no. 22745/06) this case was important because it addresses a statutory inequality created by the Criminal Proceedings Act under which, in cases prosecutable ex officio, the public prosecutor is always invited to attend the session of the Court of Appeal, while the defendant has to make a specific request to this effect.

327 Sašo Georgiev (application no. 49382/06) the incident happened while the police reservist was on duty, he wore the official uniform and used the official arm conferred to him by the State.

328 Gorgi Georgiev (application no. 26984/05)

${ }^{329}$ El-Masri (application no. 39630/09) (judgment delivered on 13 December 2012)
} 
In general, the Macedonian case law before the ECHR evolved in quantity and structurally. In what follows, we present five main types of cases whose judgments in one way or another have had the strongest influence on the interaction between the ECHR and the national institutions. The effects of each group of case judgments at national level vary in terms of the type of changes they have initiated. As we will see, in some cases, the effects are legislative changes, in others institutional or changes in the conduct (personal, educational and organizational standards) of judges and others involved in the functioning of the democratic political system that is in the functioning of the rule of law and protection of human rights.

\subsection{The five most important groups of judgments on the Republic of Macedonia}

The structure and issues raised by cases of the Republic of Macedonia changed over time. In the first ten years, over $75 \%$ of the admissible cases were on length of proceedings. Today, Macedonian cases are concerned with other aspects for better protection of human rights like for example on the right to a fair trial; problems concerning procedural aspects of Article 3; problems with the right on liberty and security and problems with the proper understanding and implementation of the right to life. Macedonian case law year by year is becoming an important part of the "evolutive" nature of the Convention as a "living instrument". 330

For a better understanding of the impact of the Convention and the case law on the Republic of Macedonia, we classify the most important judgments into five groups: cases on procedural violation on Article 3, (or the failure of the authorities to conduct an effective investigation); cases concerning the right to liberty and security; cases on the right to a fair trial (in this group we will cover the most important cases on length on proceeding, access to court, independent and impartial tribunal and equality of arms); and one case on the right to life.

\subsubsection{The failure of the authorities to conduct an effective investigation}

In the case of Jasar, the Court faced the first complaint of alleged police brutality and failure to conduct an effective investigation. The conclusion was that there had been a violation of Article 3 of the Convention because of the failure of the authorities to investigate the applicant's allegations that he was ill-treated by the police. Namely, the public prosecutor took no steps to find any evidence confirming or contradicting the account given by the applicant. The only investigative measure undertaken by the prosecutor was his request for additional information submitted to the Ministry of Interior. The inertia of the public prosecutor prevented the applicant from taking over the investigation as a subsidiary complainant and denied him access to the subsequent proceedings before the court of competent jurisdiction.

This problem in the functioning of the Macedonian judiciary system with the rule of law would appear repeatedly in the following years. In 2008, three new judgments were established on procedural aspects of Article 3 of the Convention. ${ }^{331}$ Then, for the fifth time in 2012 in the case of Gorgiev, the Court had found a violation of Article 3 of the Convention on the account of the failure of the authorities to conduct an effective investigation into the applicant's allegations. ${ }^{332}$ It is evident that, four of these five cases had in common the fact that for all of them the reason for finding violation was the inactivity of the same regional office of the public prosecutor.

The effects of theses judgments are found in the introduction of the Court's case law in the program of the Academy for Judges and Pubic Prosecutors and in the program of the Police Academy.

\footnotetext{
330 Tyrer v. UK A 26 (1978); 2 EHRR 1 \& 31 application no. 5856/72, judgment of 25 April 1978

331 Trajkoski (application no. 13191/02) judgment of 07 February 2008; Dzeladinov (application no. 13252/02))

judgment of 10 April 2008; and Sulejmanov ( application no. 69875/01 judgment of 24 April 2008

332 Gorgiev (application no. 26984/05) judgment of 19 April 2012
} 


\subsubsection{Right to liberty and security}

In the case of Vasilkoski and others, the Court concluded that in confirming the applicants' detention after 15 February 2008, the domestic courts constantly repeated the same summary formula using an identical form of words. This approach directed the Court to the conclusion that the authorities did not have regard to the applicants' individual circumstances, as their detention was extended by means of collective detention orders. The Court stressed that, at least from 15 February 2008, by failing to address concrete facts and by relying essentially on the gravity of the charges and the potential penalty, the authorities prolonged the applicants' detention on grounds, which, although "relevant", cannot be regarded as "sufficient". There had, accordingly been a violation of Article 5 $\S 3$ of the Convention. ${ }^{333}$

In the case of Lazoroski, the Court concluded that the applicant's deprivation of liberty for almost 10 hours, did not constitute lawful detention effected "on reasonable suspicion" on him having committed an offence. For the Court the "operative indications" of the Intelligence Service, in absence of any statement, information or a concrete complaint cannot be regarded as sufficient to justify the "reasonableness" of the suspicion on which the applicant's arrest and detention were based and this was basis for finding violation on Article $5 \S 1$ (c) of the Convention. ${ }^{334}$

In the case of Stojanovski, the Court was convinced that the applicant's continued confinement was manifestly disproportionate to his state of mind at that time. The conclusion was that the applicant's continued confinement in the hospital under the 2003 review had not been shown to have been necessary in those circumstances and was, therefore, unjustified within the meaning of Article $5 \S 1$ (e) of the Convention. ${ }^{335}$

This group of cases deserves particular diligence. Courts in the Republic of Macedonia will have to learn more about standards and principals in the implementation of detention as the most restrictive measure concerning Right to liberty and security.

\section{"Extraordinary rendition" case}

The case of El Masri is amongst one of the most important judgments of the Court. In this case "...for the first time, the Court found against a State for taking part in an extraordinary rendition of prisoners to the $\mathrm{CIA}$, putting an end to the impunity with which such operations had, for a long time, been carried out. Above all, our Court is the first in the world to have classified as torture the actions committed by the CIA in the context of such operations, even though it was the respondent State that was found responsible for the violation on account of the express or tacit approval of its authorities..." ${ }^{336}$. The applicant was complaining under Articles 3, 5, 8, 10 and 13 of the Convention. The Court found a violation of Articles 3 and 5 (both substantive and procedural aspects), Articles 8 and 13 of the Convention. The Court also found that the procedural obligation of the States under Article 3 of the Convention encompasses the right to the truth. ${ }^{337}$ This judgment will strongly influence the future case-law of the Court in years to come, but also it is reasonable to expect that it will put in motion certain changes in the functioning of the intelligence agencies, not only in the Republic of Macedonia.

\subsection{Right to a fair trail}

a) Length of proceedings: As we have mentioned earlier, the problem of the Macedonian judiciary system with the length of proceedings was disclosed at the earliest stages after the accession of the

\footnotetext{
333 Vasilkovski (application no. 28169/08 judgement of 28 October 2010)

334 Lazoroski (application no. 4922/04, judgment of 8 October 2009)

335 Stojanovski (application no. 1431/03, judgment 22 October 2009)

336 Speech during the Solemn hearing of the Court by Dean Spielmann, President of the European Court of Human Rights,Strasbourg, 25 January 2013

337 El-Masri, (application no. 39630/09) GC judgment of 13.12.2012
} 
country to the Convention. Because of the numerous violation judgements, the national authorities in 2008 undertook a legislative initiative to respond to the Court's judgments. The newly introduced remedy was put to the test by the Court in a number of new cases launched after the introduction of the new remedy. The case of Surbanovska was considered as a leading case regarding the effectiveness of a remedy for length of proceedings introduced in 2008. The Government submitted considerable statistical information about the application by the Supreme Court for a length of proceedings remedy. The Court declared the application inadmissible finding that the applicants, who had meanwhile used the length of proceedings remedy successfully, could no longer claim to have victim status. ${ }^{338}$ It was one year later in the case of Adzi-Spirkovska and others in which the Court found that a length of proceedings remedy introduced in 2008 could be regarded effective ex nunc. ${ }^{339}$ Based on this decision, in 2011 the Court disposed of several hundred length cases against the State.

b) Access to court: Judgment in the case of Fetaovski was the first judgment on the right to access to court on the Republic of Macedonia. ${ }^{340}$ The applicant complained about the unfairness and excessive length of civil proceedings. He also complained that he was not awarded any compensation. ${ }^{341} \mathrm{He}$ relied on Article $6 \S 1$ right to a fair hearing within a reasonable time and Article 1 of Protocol No. 1 protection of property. The Court held unanimously that there had been a violation of Article 6 in respect of the applicants' right to access to a court and to have his case heard within a reasonable time. The Court pointed out that the domestic courts ultimately dealt with the applicant's appeal solely based on the entry in the registry of the first-instance court. Although a number of attempts had been made to determine the actual date of lodging the appeal, no answer was given to the question of why the copy of the appeal (stamped 15 March 2001 of which the courts knew) had not been accepted as the date of lodging the appeal. The conclusion of the Court was that the failure by the domestic courts to accept the appeal or in the alternative, to provide a tenable reason for not accepting it, amounted to a construction of the procedural rule at issue, which deprived the applicant of his right of access to a court. ${ }^{342}$

In the case of Stojanovski, the applicant was injured in a fight. He was complaining about the excessive length of the criminal proceedings brought against the two people who had allegedly caused him grievous bodily harm and about the fact that no decision had ever been taken concerning his compensation claim brought in the course of those proceedings as the courts advised him to bring a separate civil action for damages. The Court concluded that his failure to do so could not be held to his detriment since the civil courts, as the Government argued, would have been required to wait for the outcome of the criminal proceedings. Therefore, the Court considered that the applicant could not be required to introduce, four years after he made the civil-party complaint and more than ten years after the incident, a fresh action before the civil courts seeking redress for the injuries. The conclusion was that there had accordingly been a violation of the applicant's right of access to a court. ${ }^{343}$

Equally important is the case of Petkoski and Others. The case concerns in particular the applicants' complaint that they were denied access to a court in proceedings in which they requested that a decision to restructure the cooperative be annulled. The Court noted that the decisions of the domestic courts rejecting the applicants' claims were based on the Courts Act 1995, which had removed judicial protection for property belonging to cooperatives. The main question in this case

\footnotetext{
338 Surbanoska and others, application (application no. 36665/03) dec. from 31 August 2010

${ }^{339}$ Adzi-Spirkovska and others (application no. 38914/05) and Topuzovski (application no. 17879/05) dec. from

3 November 2011

${ }^{340}$ Fetaovski, (application no. 10649/03) judgment from 19 June 2008

${ }^{341} \mathrm{He}$ brought civil proceedings for damages following the slaughter of his sheep because they were infected with a contagious disease (brucellosis).

342 Fetaovski (application no. 10649/03) judgment from 19 June $2008 \S 40$ and 41

343 Boris Stojanovski (application no. 41 916/04) judgment from 06 May $2010 \S 56$
} 
was whether this denial of access to court by way of legislative amendment was compatible with the Convention. The Court observed that the Government did not give any reason as to why it had been necessary to remove all protection for the particular type of property related to the applicants' claim. In addition, the courts did not give instruction as to which body would be competent to decide the case. The Court concluded that, no reasons had been submitted to the Court which justified the interference by that provision with the remaining applicants' right of access to a court. ${ }^{344}$

c) Independent and impartial tribunal: According to the generally accepted norm, the key precondition for independence and impartiality of the tribunal is an independent and impartial judge. This is determined on the two tests of judicial independence and impartiality: the subjective test, which determines personal convictions of a particular judge in a given case, and the objective test, which ascertains that the judge offers sufficient guarantees to exclude any legitimate doubt in respect of his independence and impartiality. Besides its structural and institutional dimensions, this standard is also very much conditioned by the culture in general and by the professional culture and ethics in particular. The two Macedonian cases brought before the Court on these grounds provided solid ground for re-examining certain national practices in the light of the standards established by the Convention and the Court's case law.

The first case of Nikolov concerned the applicant's complaint about the unfairness of proceedings with respect to a dispute over payment of insurance. He alleged that an impartial tribunal did not hear the case because the defendant's insurance company had employed the wife of the trial judge shortly after the proceedings had started. The Court held unanimously that there had been a violation of a right to an impartial tribunal. ${ }^{345}$

The second case articulated another dimension of this standard. The applicant in the case of Bajaldziev ${ }^{346}$ complained that the Supreme Court's decision in May 2005 to dismiss a legality review request, by the public prosecutor, was not impartial as its bench included a judge who had previously examined his case on appeal. The Court concluded that the fact that the judge involved in the dispute did not participate in the adoption of the decision that was challenged by the legality review request was of no relevance, since she had already formed a view as to the merits of the applicant's claim before his case was brought before the Supreme Court. For the Court in Strasbourg the judge involved lacked the requisite impartiality to the extent necessary under Article 6 of the Convention. The two cases initiated a number of seminars and training for judges in connection with this aspect of fair trial.

d) Equality of arms as a principle of justice was and still is an area in which the Courts case law plays important role in the development of rule of law in the Republic of Macedonia. It is also of utmost importance for the stabilisation of democracy because its implementation affirms the fundamental democratic idea of equality before the law, in this case of the defence and the prosecution. The principle of equality of arms implies that each party must be afforded a reasonable opportunity to present his or her case (audi alteram parti) under conditions that do not place him/her at a substantial disadvantage vis-à-vis his/her opponent. The concept of a fair trial, of which equality of arms is one aspect, implies the right for the parties to have knowledge of and to comment on all evidence adduced or observations filed.

The number of Macedonian cases involving various aspects of equality of arms principle shows that the national system faced evident difficulties in dealing with the issues involved. In the case of Grozdanoski, the applicant complained that the principle of equality of arms had been violated, as he had not been given an opportunity to comment on the company's appeal on points of law and the public prosecutor's request for the protection of legality. The company's appeal and the public prosecutor's request led to the Supreme Court's decision that was to the applicant's significant

\footnotetext{
344 Petkoski and Others (application no. 27736/03) judgment from 08 January 2009 §§ 38,39,40

345 Nikolov (application no. 41195/02) judgment from 20 December 2007

${ }^{346}$ Bajaldziev (application no.4650/06) judgment from 25 October 2011
} 
disadvantage. The procedural failure prevented the applicant from effectively participating in the proceedings before the Supreme Court and the failure to be given an opportunity to have knowledge and to comment upon the company's appeal and the public prosecutor's request led to a violation on Article $6 .^{347}$

The case of Stoimenov highlighted another aspect of the principle of equality of arms - the neutrality of experts in the proceedings in front of the courts as one of the most important aspects of the fair trial. ${ }^{348}$ The applicant was convicted on drug related offences for which he was sentenced to four years' imprisonment. Before the Court, he complained that the principle of equality of arms had been breached as the national courts had convicted him on the basis of expert reports produced by the same ministry which had brought criminal charges against him. The Court held that there had been a violation of the principle of equality of arms.

In three cases of this category the national courts bridged even more elementary aspects of the principle of equality of arms. In the case of Nasteska ${ }^{349}$ (complaining about being deprived of the opportunity to be present at the Court of Appeal's session) and Mitrevski ${ }^{350}$ (complaining about not being notified of a change of venue of the last court hearing), and equally in the case of Papadakis (complaining about unfairness of criminal proceedings and in particular, that the conviction had been based on evidence obtained by using secret surveillance and undercover agents). ${ }^{351}$

In all these cases the Court in Strasbourg found violations of the principle of equality of arms. These cases have been broadly discussed by national courts and special training seminars were organized by the Academy of Judges and Public Prosecutors on this aspect of fair trial.

\subsubsection{Right on property}

After the collapse of the communist regime, Macedonian society as all the other post-communist societies faced one of the most serious challenges of the transition toward liberal and market order - the denationalisation and re-privatisation of the national wealth. In this respect, the right to property guaranteed by the Convention provided strong legitimizing grounds for the conflictual processes of re-establishment of fundamental principles and institutions of property, which had been earlier eroded by the communist revolutions. In addition to its post-communist genealogy, the problems involving the right to property in the Republic of Macedonia originated also from its federal heritage - as a member of the former Yugoslav federation (SFRY). The effects of the Convention on the right to property are complex since the related right itself is multidimensional. The national right to property case law before the Court in Strasbourg counts five judgments. Two were related to the right to property in connection to the issue of privatization and purchasing of

\footnotetext{
347 Grozdanoski, (application no. 21510/03) judgment from 31 May 2007. The Company, being the opposing party in the proceedings, filed an appeal on points of law against the Court of Appeal's decision and at the same time, the public prosecutor filed a request for the protection of legality. According to the national legislation, they should have been communicated to the applicant.

348 Stoimenov, (application no. 17995/02) judgment from 05 April 2007

349 In the case of Nastevska, the applicant was absent when the Court of Appeal upheld the applicant's conviction. The applicant, not having been informed of the session, could not have replied to that position. Even if the public prosecutor had not been permitted to make any comments, her presence at the Court of Appeal's private sitting afforded her, an additional opportunity to bolster her opinion in private, without fear of contradiction by the applicant that lead to violation.

350 Mitrevski (application no. 33046/02) judgment from 21 June 2007. The Court found that the domestic courts could not justify changing the venue of the hearing without prior notice and that the applicant had therefore been deprived of the opportunity to attend the last and therefore crucial hearing in the proceedings. 351 Papadakis (no. 50254/07, judgement from 26 February 2013). He notably alleged that he (or his lawyer) had not been allowed to confront and question in court one of the agents, who had been involved as an agent provocateur in the undercover drug deal operation leading to his conviction and who had been the main witness in the trial against him in June 2006.
} 
apartments in property of the former federal army. ${ }^{352}$ One case ${ }^{353}$ involved the issue of effective enjoyment of the right to property as established by the court decisions given in the substantive proceedings. The other two cases (Bocvarska ${ }^{354}$ and Arsovski ${ }^{355}$ ) dealt with the issue of fair balance between the sides involved into two different rights to property cases.

Although it is still too early, we could assume that the last four judgments will have important effects on the national Courts in the Republic of Macedonia, and they might be of equal importance for other countries in the region experiencing similar problems in respect to the right to property.

\subsubsection{Right to life}

The Macedonian, right to life dossier at the ECHR counts only one specific case. In the case of Saso Gorgiev the Court found a violation of Article 2 of the Convention. The challenged party is the State, or rather some of its agencies or agents. The case concerns a police reservist, who instead of standing guard in a police station, left his post without authorisation from his superiors. He then went to a bar where he shot the applicant in his chest. The police reservist was in uniform and used his official gun. The domestic courts dismissed the applicant's compensation claim against the Ministry of the Interior finding that the police reservist had not been acting in his official capacity, but as a private person. The applicant complained under Articles 2 and 6 of the Convention. On 19 April 2012, the Court found a violation of Article 2 of the Convention in its substantive aspect in that the respondent State was to be considered responsible for unlawful actions of its agent taken outside his official duties. The incident happened while the police reservist had been on duty, he wore the official uniform and used an official arm conferred to him by the State. ${ }^{356}$

The judgement on this case is relatively recent and its execution has not yet had visible effects in terms of legislative or institutional changes. Yet, the case and the judgement have focused the public attention on the issue of staffing of state armed forces and on training of their members. ${ }^{357}$

352 Veselinski, (no 45659/99) and Dzidrovski (application 46447/99) judgments from 24 February 2005. In two separate judgments the Court dealt with identical complaints of applicants who claimed to be victims of a breach of Article 1 of Protocol No.1. The Court considered that the Supreme Court could be regarded as an unjustified interference with their peaceful enjoyment of their possessions and there had therefore been a violation of right on property. Jankulovski, (application no. 6906/03 judgment from 3 July 2008)

353 Jankulovski (application no. 6906/03 judgment from 3 July 2008). The Court noted that national court did not take any measure to enforce payment of the remaining debt and on that basis decided that failing to conduct the enforcement proceedings the State failed to comply with the obligation to secure to the applicant effective enjoyment of his right of property.

354 Bocvarska, (application no. 27865/02 judgment from 17 September 2009). The Court criticized the legal effects of the legality review proceedings under the 1998 Act since the Supreme Court had set at naught an entire judicial process, which had ended in a judicial decision that was "irreversible" and thus res judicata. The Court was with clear standing that the "fair balance" was upset by the situation brought about by the Supreme Court's decision and that the applicant bore an individual and excessive burden which leaded to a violation of on right on property.

${ }^{355}$ Arsovski, (application no.30206/06 judgment from 15 January 2013) $\S \S 61$ and 62 . This is the first judgment on Republic of Macedonia finding violation in connection with the procedure on expropriation. The case concerns issue of expropriation of a plot of land for the benefit of a private company in order to extract mineral water. The Court concluded that the total failure to take into account the specific features of the properties when ascertaining appropriate compensation had upset the requisite fair balance between the demands of the general interest of the community and the requirements of the protection of the individual's fundamental rights. The Court was with clear view that the expropriation was excessive and disproportionate to the aim sought to be achieved and accordingly in violation of right to the peaceful enjoyment of the possessions.

${ }^{356}$ Sašo Georgiev, application no. 49382/06, judgment from 19 April 2012

357 This is visible in the public statement given by the State agent after the Court brought the judgment. According to his reading of the judgment, it is a strong signal sent by the Court in Strasbourg that the State is expected to establish and fulfill highest professional standards of conduct for the persons employed in their 


\section{The European Court's Case Law's Effects}

\subsection{Legislative level}

State parties to the Convention have "undertaken to abide by the final judgments of the Court in any case to which they are parties." ${ }^{358}$ Relying on this crucial element of the subsidiary nature of the Convention, "the Court points out that the machinery of protection established by the Convention is subsidiary to the national systems for safeguarding human rights." 359 This was the reason why the Committee of Ministers stressed that "It is thus at the national level that the most effective and direct protection of the rights and freedoms guaranteed in the Convention should be ensured. This requirement concerns all state authorities, in particular the courts, the administration and the legislature." 360 The implementation of judgments of the Court might be supported greatly by involvement of national Parliaments. ${ }^{361}$

Many Parliaments in Europe are now looking to the Court's case law before amending or establishing new legislation. The legal system in the Republic of Macedonia has been influenced by the case-law of the Court in Strasbourg in the last few years. Several laws were changed as a consequence of the jurisprudence and standards of the Court. Perhaps most important are the changes to procedural laws: the new Code on Criminal Proceedings, amendments of the Civil Proceedings Act and the new Act on Administrative Disputes. All of them provide for the opportunity to request a reopening of proceedings based on a judgment by which the Court in Strasbourg has found a violation of the Convention.

The Civil Proceedings Act provides that "When the European Court of Human Rights finds a violation of certain human rights or of the fundamental freedoms protected under the European Convention for the Protection of Human Rights and Fundamental Freedoms and its additional protocols, ratified by the Republic of Macedonia, the party may, in a period of 30 days from the finality of the judgment of the European Court of Human Rights, file a request to the first-instance court in the Republic of Macedonia that decided the case in which the decision violating some human right or fundamental freedom was adopted, to amend the decision violating such right or fundamental freedom." ${ }^{362}$ This Act further stipulates that in the reopened proceedings the courts shall be obliged to follow the legal positions stated in the final judgment of the European Court.

Another important reference to the Court and its case law was introduced by amendments from 2008 to the Courts Act of 2006. Namely, this Act provides that the Supreme Court is to decide on the length of proceedings cases and "it shall take into consideration the rules and principles set forth in the European Convention..." According to the Courts Act, finding of a violation of Article 6 of the

armed forces. (See “Macedonia pays its sins from the past” “Македонија си ги плаќа „гревовите” од минатото: ..." in Академик http://www.akademik.mk/eschp accessed 03/06/2013

${ }^{358}$ Article 46 paragraph 1 of the Convention

359 Handyside v. the United Kingdom, judgment of 7 December 1976, Application no. 5493/72 and the "Belgian Linguistic" case, judgment of 23 July 1968 Series A no. 6, p. 35, para. 10

360 Appendix to Recommendation Res(2004)5 of the Committee of Ministers to member states on the verification of the compatibility of draft laws, existing laws and administrative practice with the standards laid down in the European Convention on Human Rights, § 2)

361 "Scrutiny of the government's response to an adverse judgment of the Court takes two broad forms. First, parliament should exercise oversight to ensuring that the competent authorities promptly adopt adequate measures to execute a judgment of the European Court. Parliament, in exercising a supervisory function, places expectation upon the Government to uphold their commitments under the Convention and increases the political transparency of the implementation process." (Drzemczewski Andrew and James Gaughan, 2010 "Implementing Strasbourg Court Judgments: the Parliamentary Dimension; European Yearbook on Human Rights 2010, European Academic Press, pgs 233 - 244)

${ }^{362}$ Civil Proceedings Act, Article 400 
Convention is grounds for dismissal of a judge who had conducted the proceedings in respect to which the violation was found. It is considered, under the Courts Act, as a professional misconduct. ${ }^{363}$

At the same time, under the Judicial Council Act, proceedings for dismissal of a judge due to a professional misconduct may not be initiated if more than five years have elapsed from the day when the misconduct had taken place. This time-scale does not apply to cases in which the Court has found a violation of Article 6 of the Convention. ${ }^{364}$ In 2009 a special Act on the Enforcement of Decisions of the European Court of Human Rights, ${ }^{365}$ was established. The Act on Civil Liability for Insult and Defamation, recently adopted, is another example of the introduction of the Court's case law in to the national law. ${ }^{366}$ This Act specifies that limitations to the freedom of expression and information are regulated exclusively through strictly determined conditions for civil liability for insult and defamation. ${ }^{367}$

The role of the Macedonian Parliament in the implementation of the judgments of the Court should be much stronger than it is at moment. The Parliament can exercise an important role in two different respects: first, as legislator, and then in their role of holding the government to account. There are different means by which the Parliament can hold government to account: debates, parliamentary questions, and committees. ${ }^{368}$

\subsection{Judiciary}

During the past five years, the impact of the case-law of the Court on domestic judiciary increased inevitably. Despite the fact that at the beginning the domestic courts approached the case law of the Court, with a reserved attitude, today we are witnessing the implementation of the Court's principles in the judgments of high-level domestic courts - the Constitutional court and the Supreme Court.

The Constitutional Court has started to take into account not only the Convention, but also to refer to the principles. By its Resolution U.br.28/2008 from 23.04.2008 the Constitutional Court of the Republic of Macedonia decided on the initiative concerning the constitutionality of the Criminal Code. The analysis of this Resolution quoted the more recent case law of the European Court for Human Rights in view of life sentence (Leger v. France, Judgment of 11 April 2006, Kafkaris v. Cyprus, Judgment of the Grand Court Chamber of 12 February 2008; Stanford v. the U.K., Hill v. the U.K., no.19365/02, Wynne v. the U.K.). For the Constitutional Court it was important that "...although the Convention generally does not provide for the right to release on parole or the right to have the sentence revised by the national authorities (judicial or administrative) in order to reduce or terminate it, from the case law it clearly derives that the existence of a system which envisages the consideration of the possibility for release is an important factor that should be taken into account when assessing the compatibility of the individual life sentence with Article 3 of the Convention." 369

After the judgment in the case of Stoimenov from 5 April 2007,370 envisaging that it will take a long time to amend or to change the Law on Criminal Procedure, the Department of Criminal Offences of the Supreme Court took a Legal Position in favour of direct applicability of the Court's case law: "For each and every freedom and right foreseen in the Convention and whose protection is effectuated before the ECtHR, the courts in RM directly apply its judgements and, in accordance with the Law on

\footnotetext{
363 Ibid, Article 75, §1

364 Judicial Council Act, Article 74, §5

365 "Official Gazette of the Republic of Macedonia" no. 67/2009

366 "Official Gazette of the Republic of Macedonia" no. 143/2012

${ }^{367}$ Act on Civil Liability for Insult and Defamation, Article 2, §2,

368 For more details on this subject see the analysis of Drzemczewski Andrew and James Gaughan: Implementing Strasbourg Court Judgments: the Parliamentary Dimension;

369 U.br. 28/2008 of 23.04.2008 (http://www.ustavensud.mk/domino/WEBSUD.nsf ; last access 13.03,2013)

370 Stoimenov (application no. 17995/02) judgment of 5.April 2007
} 
Criminal Procedure, in the reasons of their decisions should invoke the case-law of the ECtHR". ${ }^{371}$ This was a clear message to all courts that they like the Supreme Court in criminal procedures will have to implement provisions and the case law of the Convention directly. In the case of Petkovski and others, the Court had established that there had been a violation of Article $6 \S 1$ of the Convention in respect of the applicants' rights to access to a court. As a result of this judgment, the Department on Civil Offences at the Supreme Court established and published the Conclusion that Section 400 of the Civil Proceedings Act of 2005 provides that, a case may be reopened if the European Court of Human Rights has given a final judgment finding a violation of the Convention and therefore the conclusion was that the applicants may ask for a reopening of the civil proceeding in their case. ${ }^{372}$

\subsection{Remedies}

Under direct influence of the Court's case law on Macedonia, a remedy on length of proceedings was introduced with the Courts Act in 2008. ${ }^{373}$ Later on, by the decision in the case of Adži-Spirkoska and Others ${ }^{374}$, the Court in Strasbourg found that the newly introduced remedy is effective within the meaning of the Convention and that applicants should avail themselves of that remedy before they bring their length complaints before the Court.

Under the Act on the Enforcement of Decisions of the European Court of Human Rights, the Court's judgments against Macedonia in which a violation was found are communicated to the Supreme Court, the Administrative Court, to the appellate court and to the Court of First Instance that conducted the relevant domestic proceedings. ${ }^{375}$ Furthermore, one of the competencies of the Government Agent's Office ${ }^{376}$ is to make a continuing analysis of the Court's case law and inform the domestic courts and other State authorities thereof. The ECHR is part of the Programme for continuing education of judges and public prosecutors of the Academy for Judges and Public Prosecutors. ${ }^{377}$ The qualification exam for admission at the Academy requires knowledge of the most important judgments of the Court. ${ }^{378}$

One of the most interesting effects of the Courts case law on available national remedies for protection of human rights and thus for rule of law and development of a democratic political system is seen in the more and more frequent and better supported arguments in favor of extending the jurisdictions of the Constitutional Court of the Republic of Macedonia in the protection of the human rights and freedoms. ${ }^{379}$ The need for an extension of the Constitutional Court's jurisdiction has been supported by distinguished legal experts and elaborated on the grounds of the ECHR and the Macedonian case law affront of the Court. ${ }^{380}$

\footnotetext{
37129 June 2007, Legal Position of the Department of Criminal Offences of the Supreme Court

372 Conclusion of the Department of Civil Offences of the Supreme Court from 8 June 2010 on the reopening of the procedure on the basis of Article 400 of the Code of Civil Procedure 373 "Official Gazette of the Republic of Macedonia" nos. 58/2006, 35/2008, 150/2010

${ }^{374}$ Adži-Spirkoska and Others (application nos. 38914/05 and 17879/05) dec. 3 November 2011)

${ }^{375}$ Act on the Enforcement of Decisions of the European Court of Human Rights, Article 22

${ }^{376}$ Established with the Act on Representation of the Republic of Macedonia before the European Court of Human Rights (“Official Gazette of the Republic of Macedonia” no. 67/2009)

377 The Programme is available at the website of the Academy: http://www.jpacademy.gov.mk/, last visited on

17 January 2013

378 Academy for Judges and Prosecutors Act, Article 50, §1

379 This question is regulated by the Article 110 paragraph 3

380 See Arsov Jordan, "The Role of the Constitutional Court of the Republic of Macedonia in the protection of the rights and freedoms of men and citizens ..." ( Арсов Јордан, Улогата на уставниот суд на Република Македонија во заштита на слободата и правата на човекот и граѓанинот повредени со поединечен акт или дејство) in Правен Дијалог Број 3, 24 Јуни 2011, http://www.ihr.org.mk/mk/praven-dijalog/pravendijalog-br3/133-uloga-na-ustavniot-sud-na-rm.html accessed 02/06/2013
} 


\subsection{Executive level}

The development of the system of execution of the Court's decisions and judgments against the Republic of Macedonia is one of the good practices developed in the interaction between the Court and the national authorities. Even until 2009, the execution was one of the weaknesses of the national system of human rights protection. In this year, the Parliament adopted the Law on the Enforcement of Decisions of the European Court of Human Rights. ${ }^{381}$ On this ground, later on two important institutions were legally established: the Bureau of the Government's agent and the Interdepartmental Committee ("the Committee") for execution of Court's judgments.

In accordance with the Law, the Interdepartmental Committee was established to monitor the enforcement of the judgments and decisions of the European Court of Human Rights. The Committee may recommend to competent State authorities specific and general measures in order to remedy a violation found by the Court, or its consequences, or in order to prevent any further violations. The general measures may include legislative amendments of acts, the application of which led to the finding of a violation; change of administrative practices; giving legal opinion in drafting laws; professional development and training of judges, public prosecutors, lawyers and State officials in order to ensure a correct implementation of the Convention and the Court's case law. It can also propose other measures aimed to eliminate systematic problems and to ensure the payment of just satisfaction. ${ }^{382}$ The Committee also has a general competence to propose improvements of human rights related legislation. ${ }^{383}$

\section{The impact of Macedonian cases on the Court's case-law}

Macedonian cases have often been cited in the Court's case law. The case of Jasar has been used by the Court to reiterate the principle that, where domestic proceedings have taken place, it is not its task to substitute its own assessment of the facts for that of the domestic courts and, as a general rule, it is for those courts to assess the evidence before them ${ }^{384}$.

The Judgment of Atanasovski385, is quoted in cases that concern alleged judicial inconsistency, where the Court held that case-law development is not, in itself, contrary to the proper administration of justice since a failure to maintain a dynamic and evolutive approach would risk rendering it a barrier to reform or improvement.

In connection with cases where a new remedy is not effective within the meaning of the Convention, the Court often refers to the judgment in the case of Parizov. ${ }^{386}$

Another example is the case of Božinovski. ${ }^{387}$ It is about the situation when an applicant submits only documents from the domestic proceedings which are not sufficient to constitute an introduction of a complaint. At least a summary indication of the nature of the alleged violation under the Convention is required to introduce a complaint and thereby interrupt the running of the six-month time limit. This case is also mentioned in the Admissibility Guide. Similarly, the Admissibility Guide refers to the case of Stojkovic ${ }^{388}$ to illustrate the Court's position on the victim status of an heir or family member of the deceased applicant. The case of Vasilkovski ${ }^{389}$ is an example used by the Court to state that applicants may be dispensed from exhausting a remedy, which has proved ineffective in practice.

\footnotetext{
381 Законот за извршување на одлуките на ЕСЧП (“Сл. весник на РМ” бр. 67/2009)

382 Act on the Enforcement of Decisions of the European Court of Human Rights, Article 27

383 Ibid, Article 11, paragraph 1, 3)

${ }^{384}$ See Gäfgen v. Germany [GC], no. 22978/05, 1 June 2010

385 Atanasovski (no. 36815/03, 14 January 2010)

386 Parizov (no. 14258/03, 7 February 2008)

387 Božinovski (dec.), 68368/01, 1 February 2005)

388 Stojkovic (no. 14818/02, 8 November 2007)

${ }^{389}$ Vasilkoski (no. 28169/08, 28 October 2010).
} 
The recent Grand Chamber judgment in the case of El-Masri390 is likely to influence the Court's case law in future, bearing in mind that it was the first judgment in which the Court thoroughly dealt with the issue of extraordinary rendition. In this connection, it is worth noting that there are cases against other States concerning this issue pending before the Court.

\section{Conclusions}

The analysis shows important effects of the ECHR and the Court's case law on the human rights protection system of the Republic of Macedonia and through that avenue on the democratic political development and the rule of law. The interaction went through two distinctive periods in terms of the issues and the main actors involved. In the first period-before and soon after the ratification of the Convention - the main issues influencing the domestic developments were questions about the accordance of the national political, legal and judicial systems with the principles of the Convention and the Court's case law standards and practices. The politicians and legislators played the main role in transferring and interpreting the importance and the mission of the Convention and the Court. In the second period, after the ratification the main avenue of influence was the implementation of the Courts judgments in relation to the Republic of Macedonia. The judges at the national courts played the main role in this phase. At the time of ratification, some sixteen years ago, the case law of the European Court of Human Rights was not of relevance for Macedonian courts and other institutions. Courts were relying on the Constitution, laws and opinions of a general nature of the Supreme Court. Like in most of the post-communist countries, the Macedonian courts "were never required to consider the Convention as a 'constitutional instrument of European public order' and to take into account the public interest of the international community." 391

Today, through the dialogue between, the Court in Strasbourg including the other institutions of the Council of Europe and, the Macedonian authorities at the different level of governance, the Convention has become an integral element of the system of the protection of human rights in the Republic of Macedonia. One of the most visible effects of the ECHR on the country is the fact that the Convention is today perceived as a "part of the domestic legal order and as directly applicable."392 The Constitutional Court, the Supreme Court and the other courts and institutions apply the Court's case law to the best of their knowledge and capacities.

The frequency of use of the case law of the Strasbourg Court is not the only and the best indicator of the effects of the Convention and the case law on the country. What is more important is the positive trend of opening of the domestic legislative, judiciary and executive levels towards the case law. On that path, the national case law has played the role of key pillar through which the Court's standards are domesticated. It is evident from the case law on the Republic of Macedonia that there were many mistakes during the investigative part of the criminal procedure and this was leading to violations on Article 3 of the Convention in several cases. It is notable that there is a lack of the principles and standards in the implementation of the measures by which the right on freedom and security is in breached, but also a lack of knowledge about the main principles on fair trial. Of course, this model of learning by its own mistakes and failures is longer and more costly but as life is the best tutor, so is the national case law before the Court in Strasbourg. Its reception, interpretation and implementation contribute to the building of a human rights culture, which is essential for the stabilization of democratic political institutions and rule of law in the country

Established judgments and decisions do reflect the reality on administrative, judicial proceedings and the legal policy. It is evident that in the last five years, because of the influence of the case law

\footnotetext{
390 El-Masri (no. 39630/09, 13 December 2012)

391 Maruste, Rait 2007, "The impact of the accession of Eastern block countries on the Convention machinery and its case-law", in Liber amicorum Luzius Wildhaber : human rights, Strasbourg views = Droits de l'homme, eds. Lucius Caflisch ... [et al.]. - Kehl ; Strasbourg ; Arlington, Va. : N.P. Engel, pg. 291

39229 June 2007, Legal Position of the Department of Criminal Offences of the Supreme Court
} 
of Strasbourg, procedural laws have been amended, Law on the Courts was amended, and a new Law on the execution of the judgments of the ECHR was established.

In the past sixteen years, like most of the new members of the Convention, the Republic of Macedonia was learning and adapting to the doctrine of a well-balanced synthesis of common law and the continental civil law. The results achieved could be described as "work in progress". Despite the fact that the Convention is "accepted as a part of national legal system and as directly applicable" 393 it seems that the case law of the Court is used in a formalistic way without substantive analysis. It will take time and a lot of education and training of judges from all instances. In the meantime, it seems that Macedonian cases are becoming an important part of the Court's case law and they are used as a reference in other cases at the level of the Court.

The experience and knowledge gained emphasise the importance of education and training in connection with the Convention and the case law. An important step towards this direction is the introduction of the Convention and the case law in the Programme for the Bar exam, in the exam for private executors and in the Program of the Academy of judges and public prosecutors.

39329 June 2007, Legal view of the Department of criminal offenses at the Supreme Court of the Republic of Macedonia 29 јуни 2007, Правен став на Одделот за казниви дела при Врховниот Суд на Република Македонија 


\title{
MONTENEGRO
}

\author{
Nebojša B. Vučinić ${ }^{*}$
}

\section{The effect of the Convention on the legal system of Montenegro}

While the Convention entered into force in respect of Montenegro on 3 March 2004, the Court really began to examine the cases against Montenegro in 2009 ${ }^{394}$. To date, more than 800 cases have been declared inadmissible, and the Court has delivered 34 judgments and 29 decisions on admissibility. There have been no Grand Chamber cases as yet and no established systemic or endemic issues and, consequently, no Article 46 declarations or pilot judgment procedures. Consequently, the Convention has not yet had a structural and long-lasting impact on the legal system of Montenegro.

Nevertheless, it could be said that the Convention's impact has been important: certain problems and shortcomings have been identified and, influenced by the judgments of the Court, they are currently being dealt with on the domestic level. One of the main objects of the Convention and of the case-law of the Court, the domestic implementation of the standards developed by the Court, is slowly starting to be accomplished.

Pursuant to Article 9 of the Constitution of Montenegro, ratified and published international treaties and generally accepted rules of international law are an integral part of the Montenegrin legal system, are superior to national legislation and shall apply directly when they regulate relations differently to national legislation. In that way, the Constitution of Montenegro adopted a clear monistic position concerning the priority of international over national law, which is particularly important for the implementation of human rights. In practice, this means that, not only treaties such as the European Convention on Human Rights but also, judgments and decisions of international courts, have supremacy over national legislation. ${ }^{395}$

The judgment of the Court, in the case of Bijelić v. Montenegro and Serbia ${ }^{396}$, is significant, not for its impact on the domestic legal system, but rather because it was the first judgment. It is also important for public international and universal human rights law, notably, for the following reason: this judgment represents a considerable contribution to customary international law concerning the validity of international treaties on human rights in the context situation of the peaceful division (dissolution) of a state and state succession, i.e. the changing the political status of the territory concerned. One of the principal questions raised in this case was the question of the temporalratione temporis - application of the Convention in respect of Montenegro, given the independence of Montenegro proclaimed on 6 June 2006 pursuant to the democratic referendum held on 21 May 2006 in which majority of citizens voted in favour of re-establishing ${ }^{397}$ an independent State of Montenegro.

\footnotetext{
394 The mandate of the Judge elected in respect of Montenegro began on 25 August 2008. The Registry lawyer joined the Registry in January 2009. However, certain cases had been examined and declared inadmissible by the Court prior to these dates.

395 Article 9 of the Constitution of Montenegro, 2007.

396 ECHR, no. 11890/05, 28 April 2009

397 The Principality of Montenegro (from 1910 the Kingdom of Montenegro) was recognized as an independent State at the Berlin Congress on 13 July 1878. At the end of November 1918, during an illegitimate and unlawful so-called "Great National Assembly" organized by supporters of the Kingdom of Serbia with the help of Serbian armed forces, the Kingdom of Montenegro was abrogated and the so-called unconditional unification was proclaimed: this was practically subjugation to the Kingdom of Serbia. In that way Montenegro ceased to exist as a political and national subject. After World War II and the socialist revolution, Montenegro regained part of its statehood as the Socialist Republic of Montenegro was established as a federal unit in the framework of the Yugoslav federation with "inherent right to self-determination of the people" including the right to opt for
} 
In the Bijelic judgment, the Court ruled that the Convention had continued to be binding on Montenegro since 3 March 2004 namely, when the State Union of Serbia and Montenegro joined the Council of Europe and ratified the European Convention on Human Rights, a situation which ended in May 2007 when Montenegro itself became a full member of the Council of Europe and a party to the Convention. Consequently, this judgment dismissed any uncertainties about this ratione temporis issue in respect of Montenegro prior to May 2007. At the same time, by this same reasoning, the Court confirmed a rule very close to customary international law that human rights treaties, which had already been in force in respect of one territory or of federal units, continued to be binding for the territory, regardless of political changes, such as obtaining independence. This line of reasoning is based on the preposition that a human rights treaty is a very specific type of international treaty, with the primary purpose of protecting individual human beings from any Government abuses or intrusions. In adopting this approach, the Court also took into consideration the opinion of third-parties namely, of the Venice Commission and of "Human Rights Action", an NGO from Podgorica. They argued that Montenegro should be deemed responsible for any and all violations of the Convention and/or its Protocols committed by its authorities as of 3 March 2004, which was when these instruments had entered into force in respect of the State Union of Serbia and Montenegro.

In support of this argument the Court referred to practical considerations, the domestic and international context surrounding the Montenegrin declaration of independence, its own established practice regarding Czech and Slovak Republics ${ }^{398}$ and the opinion of the Human Rights Committee (ICCPR) on the issue of state succession and the continuation of human rights treaties. By resolving this particular case against Montenegro, the Court considerably contributed to the clarification of this legal issue of general importance and indirectly improved the principles of legal security and certainty.

The principal positive result of the judgment in the case Garzičić v. Montenegro ${ }^{399}$ was the change of the practice of the Supreme Court of Montenegro as regards the determination of the value in civil disputes/claims and the elimination of the excessive formalism of the Montenegrin courts in this context. More precisely, having found a violation of Article $6 \S 1$ (access to the court), the Court assessed as an excessively formalistic the practice of the Supreme Court concerning an appeal on points of law (revision). Until then, the party had been obliged to assess the value of the claim. If the assessment was unrealistic, the courts could assess the value themselves. In Garzičic the appellant failed to make the assessment so the lowers courts did so. However, the Supreme Court on appeal completely ignored the fact that the lower courts had determined the value of the dispute and the Supreme Court rejected the appeal on points of law for this formal reason without examining the merits of the case.

More precisely, the Court considered that, even though the domestic courts - including the Supreme Court - had no strict and explicit obligation in this respect, there was no provision in the Civil Procedure Act that would prohibit the courts from establishing the value of the dispute when the plaintiff had failed to do so in the statement of a claim. In this case, the domestic courts already established the value of the claim, in both the first and second remittal and had taken into account expert findings as well as the value specified by the parties themselves. Although these values

their own State (see Z. Perić, "Crna Gora u jugoslovenskoj federaciji”, Podgorica, 1999; M. Šuković, "Podgorička skupština 1918", Podgorica 1999; N. B. Vučinić, “Osnovi ljudskih prava i sloboda”, p. 154). Pursuant to a decision of Badinter's Arbitration Commission for former Yugoslavia, this right was confirmed to all the units of the Federation of Yugoslavia. Under the auspices of the European Union, and on condition of a special qualified majority a democratic referendum was held on 21 May 2006, in which the majority voted for reestablishing independent Montenegro; Norman Davies, "Vanished Kingdoms - The History of Half-Forgotten Europe", Penguin books 2012, pp. 600-620.

398 Konečný v. the Czech Republic, nos. 47269/99, 64656/01 and 65002/01, 26 October 2004.

${ }^{399}$ ECHR, no. 17931/07, 21 September 2010. 
differed, the Court did not consider it necessary to determine which of the two was more accurate as both of them allowed for an appeal on points of law in accordance with article $382 \S 3$ of the Civil Procedure Act 1977. The Court ruled that, in any event, the applicant should not suffer any detriment on account of the domestic courts' failure to order the applicant to pay the difference between the court fees that had been paid and the fees that corresponded to the established values of the claim.

Therefore, the Court assessed that the afore-mentioned practice of the Supreme Court of Montenegro amounted to an excessive formalism and found that there had been a breach of the applicant's right of access to the Supreme Court, and accordingly a violation of Article $6 \S 1$ of the Convention. In the re-trial following the Court's judgment ${ }^{400}$, the Supreme Court fully accepted the Court's line of reasoning, changed the practice, allowed for the applicant's appeal on points of law and examined the case on the merits. This practice was subsequently followed by the lower courts. It is noteworthy to add that, at approximately the same time, the Constitutional Court of Montenegro ${ }^{401}$ also decided on a the constitutional appeal of another appellant raising the same issue and it fully endorsed the standard developed in the Court's jurisprudence, ruling that the afore-mentioned practice of the Supreme Court was excessively formalistic and constituted a violation of the right of access to the court. In this way, the Court's case-law was incorporated into domestic jurisprudence.

Several judgments had been rendered by the Court on the subject of the excessive length of domestic proceedings including the length of enforcement proceedings (Živaljević v. Montenegro, Stakić v. Montenegro, Novović v. Montenegro and Serbia, and Vukelić v. Montenegro ${ }^{402}$ ): this resulted in a considerable decrease in the back-log of cases on a domestic level. While excessively long proceedings is not a systemic problem in Montenegro, it remains a significant and, to a certain extent, a widespread issue. The Right to a Trial within a Reasonable Time $\mathrm{Act}^{403}$ was adopted in 2007 following the model of the "Pinto" and "Kudla" laws, i.e. the Italian and Polish laws adopted to deal with the excessive length of domestic proceedings further to this Court's extensive jurisprudence against, inter alia, those States on the subjects.

However, even before this Act was adopted it would appear that there was sufficient legal basis for dealing with complaints in about excessively long proceedings. Several laws in force at the time provided for this possibility. In particular, section 7 of the Courts Act provides that everybody had the right to an impartial trial within a reasonable time. Furthermore, section 11 of the Civil Procedure Act ensures, inter alia, that the domestic courts have an obligation to ensure that proceedings are conducted without delay and within a reasonable period of time. Finally, section 172(1) of the Obligations Act, in force at the time, provided that a legal entity (which includes the State) was liable for any damage to a third party by one of its bodies in exercising its functions or functions in relation thereto.

However, in spite of these seemingly clear provisions, the Supreme Court of Montenegro considered differently and issued an opinion on this matter:

\footnotetext{
"The domestic legal system offers no legal remedy against violations of the right to a hearing within a reasonable time, which is why the courts in the Republic of Montenegro have no jurisdiction to rule in respect of claims seeking non-pecuniary damages caused by a breach of this right. Any person who considers himself a victim of a violation of this right may therefore lodge an application with the

400 Section 428a of the Civil Procedure Act of Montenegro provides for the possibility of a retrial following a judgment of the European Court of Human Rights finding a violation of a certain human rights or freedom.

${ }^{401} \mathrm{http}: / /$ www.ustavnisudcg.co.me/slike/ustavnisud/praksa.htm

402 ECHR, no. 17229/04, 8 March 2011; ECHR, no. 49320/07, 2 October 2012; ECHR, no. 13210/05, 23 October 2012; and ECHR, no. 58258/09, 4 June 2013

${ }^{403}$ Published in the Official Gazette of Montenegro no. 11/07.
} 
European Court of Human Rights, within six months as of the adoption of the final judgment by the domestic courts.

[When asked to rule in respect of the compensation claims referred to above] ... the courts in the Republic of Montenegro must decline jurisdiction ... and declare ... [them] ... inadmissible (pursuant to Article 19 para. 3 of the Civil Procedure Code).

[...]

The right to a hearing within a reasonable time is provided in Article 7 of the Courts Act, whereas the Civil Proceedings Code provides in Article 11 para. 1 a duty of the courts to attempt to conduct the proceedings without delays, within a reasonable time...

Article 200 of the Obligations Act provides that ... non-pecuniary damage can be awarded for ... violations of ... the rights of individuals...

It can be concluded from the above-mentioned regulations that the legal system guarantees everybody the right to a hearing within a reasonable time, and not only because the European Convention on Human Rights is directly applicable on the national level, but also because the domestic legislation explicitly provides for that right".

In this way, the Supreme Court of Montenegro unfortunately showed a complete misunderstanding of its own role as a supreme judicial body which is competent, amongst other things, to ensure consistent case-law and to interpret and apply the laws as "living instruments", misunderstanding also the subsidiary role of the European Court of Human Rights.

The Court then communicated several such complaints to the Government of Montenegro and the parties have reached a friendly settlement further to which the Government agreed to pay ex gratia certain sums of money in compensation for non-pecuniary damage and for costs and expenses, thereby acknowledging that there had been a violation of the related rights. ${ }^{404}$

The Montenegrin legislation provides, under certain circumstances, for the possibility of having lengthy proceedings expedited by means of a request for review, as well as an opportunity for the claimants to be awarded compensation therefor by means of an action for fair redress. Section 44, in particular, provides that this Act shall be applied retroactively to all proceedings from 3 March 2004, but that the duration of proceedings before that date shall also be taken into account. This Act entered into force on 21 December 2007. It did not refer to "delay" applications then pending with the Court.

More precisely, section 10 of the Act provides that the President of the relevant court shall decide upon the request for review, which, pursuant to section 9, is to be submitted to the court before which the case is pending and must contain the name and the address of the party; the registration number of the case or other data on the basis of which it can be established to which case the request refers; the data and the circumstances indicating why it is claimed the court is unjustifiably prolonging the proceedings; and the signature of the party. Section 17 provides that, if the judge notifies the President of the court that certain procedural measures will be undertaken no later than four months after the receipt of the request for review, the President of the court shall notify the party thereof and thus finalise the procedure upon the request for review. Section $23 \S 1$ provides that, if the President of the court acts pursuant to section 17, the party cannot file another request for review in the same case before the expiry of the period specified in the notification. Pursuant to section $24 \S 1$, if the President of the court does not deliver a notification on the request for review to the party in accordance with section 17 , the party may lodge an appeal.

In all the afore-mentioned "length" cases, the Government of Montenegro relied on Grzinčič v. Slovenia ${ }^{405}$ to ask the Court to declare these applications inadmissible because the applicants had

404 Vujisic and others v. Montenegro (dec.), 4 June 2013.

${ }^{405}$ ECHR, no. 26867/02, 3 May 2007. 
not did not use retroactively this new statutory remedy (the 2007 Act). However, the Court dismissed those preliminary objections and considered that these complaints were not manifestly illfounded for two principal reasons:

Firstly, the Court observed that in cases against Slovenia, Poland and Italy, specific legislation as regards the length of proceedings was enacted mainly in answer to a great number of applications already pending before the Court, indicating a systemic problem in these States. These laws also contained specific transitional provisions bringing within the jurisdiction of domestic courts the cases already pending before the European Court (Grzinčič v. Slovenia, cited above, § 48; Charzyński v. Poland (dec.) ${ }^{406}$; Brusco v. Italy (dec.) ${ }^{407}$ ). Accordingly, the Court considered that those States should be afforded an opportunity to prevent or to put right the alleged violation themselves and therefore allowed for an exception to the general rule that the assessment of whether domestic remedies have been exhausted is carried out with reference to the date on which the application was lodged. Furthermore, the Court allowed for such an exception even though the relevant remedies had been recently introduced and there was no established domestic case-law confirming their effectiveness (Giacometti and Others v. Italy (dec.) ${ }^{408}$; Ahlskog v. Finland, (dec.) ${ }^{409}$; Nogolica v. Croatia, (dec.) ${ }^{410}$; and Grzinčič v. Slovenia, cited above). The Court had no reason to doubt the effectiveness of these remedies even at such an early stage after their introduction.

Secondly, the Montenegrin Right to a Trial within a Reasonable Time Act had not been adopted with the aim of dealing with a structural problem nor in answer to a great number of applications already pending before the Court. Unlike in the above cases against, inter alia, Italy and Croatia, the Montenegrin Act had been in force for about three years when the applicants from Montenegro lodged their complaints before the European Court. While the majority of the requests for review were dealt with by setting periods in which certain procedural measures were to be undertaken, until the application in the case Vukelić v. Montenegro, the Government had provided no information as to whether these actions and time-limits had been complied with and if the proceedings had indeed been expedited and/or concluded. In addition, unlike the Slovenian, Polish and Italian laws, which contained transitional provisions concerning the cases already pending before the Court, the Montenegrin Act did not contain such provisions which would explicitly bring such applications within the jurisdiction of the national courts.

Since the proceedings in the afore-mentioned cases against Montenegro had been pending domestically for years (from 7 to 11 years) before the introduction of the legislation referred to above and since they had not yet been decided when the relevant Act was adopted, and since the Government did not submit any case-law proving the effectiveness of the afore-mentioned remedy, the Court considered that it would be unreasonable to require the applicants to try this avenue of redress.

However, in case Vukelić v. Montenegro, communicated in 2010 and re-communicated in 2012, the Court asked the Government for a factual up-date, and, in particular, for the relevant domestic caselaw adopted pursuant to the Right to a Trial within a Reasonable Time Act. According to the information provided by the Government, between 21 December 2007 (when the that Act entered into force) and 3 September 2012, the courts in Montenegro had considered more than 121 requests for review. The Court of First Instance in Cetinje submitted data only for the period between May 2011 and May 2012, and the Court of First Instance in Žabljak for the period between January 2011 and June 2012. In addition, the Court of First Instance in Danilovgrad and the Court of

\footnotetext{
${ }^{406}$ ECHR, no. 15212/03, § 20, ECHR 2005-V.

${ }^{407}$ ECHR, no. 69789/01, ECHR 2001-IX.

${ }^{408}$ ECHR, no. 34939/97, ECHR 2001-XII.

${ }^{409}$ ECHR, no.52380/07.

${ }^{410}$ ECHR, no.77784/01.
} 
First Instance in Kolašin did not provide the exact number of requests that had been dealt with by these two courts. All the other courts, dealt with 121 requests for review in total.

In forty-six cases, the courts issued notifications specifying the concrete actions that were to be taken in each case within four months with a view of expediting the proceedings. In thirty of these forty-six cases, the relevant actions were undertaken within the time-limit fixed (a main hearing concluded, a decision or a judgment rendered etc.). In fourteen of the forty-six cases, the relevant actions were undertaken within periods ranging from 4 to 12 months. In two of the forty-six cases, the relevant action specified in the notification would not appear to have been undertaken even after a period of 12 months.

In thirty-three cases, the requests for review were dismissed as unfounded. In twenty-one of these thirty-three cases, the relevant domestic proceedings would appear to have been pending before the first-instance courts from 5 months to 1 year and nine months. In one case, the relevant civil proceedings, in respect of which the request for review was dismissed as unfounded, had already been pending for at least 4 years and 5 months before a first-instance court. In eleven cases, it is unclear how long the relevant domestic proceedings had lasted.

It is also unclear how the additional thirty-three requests for review had been dealt with. However, it would appear that in eighteen out of these thirty-three cases the relevant domestic proceedings ended soon thereafter. The status of the remaining fifteen actions is not known.

Lastly, in five cases the appellants were informed that the relevant decisions had been rendered in the meantime and, in four cases, the requests for review had been withdrawn. ${ }^{411}$

Consequently, the Court observed that the Montenegrin case-law on the request for review had considerably evolved. In particular, in nearly all the cases in which the relevant domestic courts specified a time-limit for undertaking certain procedural activities, these activities had indeed been undertaken and, in most cases, in a timely manner. It also appeared that there had been a basis for the rejection of most of the requests for review that were dismissed as unfounded. While there were some cases in which the outcome of the request for review was rather unclear, the Court considered that, in view of the considerable development of the relevant domestic case-law on this issue, a request for review must, in principle and whenever available in accordance with the relevant legislation, be considered an effective domestic remedy within the meaning of Article $35 \S 1$ of the Convention, in respect of all applications introduced against Montenegro after the date when this judgment would become final.

The Court also held that an action for fair redress is not capable of expediting proceedings while they are still pending (see Mijušković v. Montenegro ${ }^{412}$ ).

It would appear that the Court's case-law in respect of Montenegro, namely several judgments in which the Court found violations of a right to a trial within a reasonable time, considerably influenced the evolution of domestic case-law in this regard. Furthermore, it can be concluded that the Court's case-law in this context represented a considerable impetus for full, efficient and effective implementation of the 2007 Act and the positive evolution of the case-law. This Court's case-law also considerably influenced, albeit indirectly, the substantial decrease of the general backlog in the Montenegrin courts: more than $70 \%$ in the past two years, according to the latest Report of the Supreme Court of Montenegro. ${ }^{413}$

The Court adopted two judgments against Montenegro concerning Article 10 of the Convention, Šabanović v. Montenegro and Serbia414 and Koprivica v. Montenegro ${ }^{415}$, in which it found violations

\footnotetext{
${ }^{411}$ Vukelić v. Montenegro, cited above, §§ 67-71, 4 June 2013.

412 ECHR, no. 49337/07, § 72, 21 September 2010.

$413 \mathrm{http}: / /$ sudovi.me/vrhs/vrhovni-sud/o-vrhovnom-sudu/

414 ECHR, no. 5995/06, 31 May 2011.
} 
of the applicants' rights to freedom of expression. As in other former communist countries, this is a very sensitive and open, political and legal issue in Montenegro, especially for the courts. The main problem, in this context, is the readiness and capacity of the domestic courts, including the highest, to apply properly the standards and principles developed in the Court's rich case-law concerning Article 10 of the Convention. This is particularly so as regards the implementation of the test to assess, in a concrete case, the compatibility of an interference under Article $10 \S 2$ of the Convention.

Prior to these judgments, the case-law of the Montenegrin courts on the relationship between the rights of privacy and expression clearly showed a tendency to protect more privacy, namely the reputation and honour of an allegedly insulted person. This was the heritage of a socialist approach as well as of a conservative patriarchal society in which reputation and honour were the most important values for personal self-determination.

This issue is rather more important than the issue of the decriminalisation of defamation, which is currently being considered in a great number of member states of the Council of Europe because freedom of expression can be, and still is, endangered with high awards compensations for defamation in civil cases. Therefore, it is most important that domestic courts are capable of applying the afore-mentioned test namely, the standards and principles from the Court's case-law regarding Article $10 \S 2$ of the Convention.

After these two judgments against Montenegro delivered by the Court in 2011, the Constitutional Court of Montenegro in 2012, for the first time, successfully and properly applied the said test during a constitutional appeal in the case of Mr Nikolaidis ${ }^{116}$. In that case, the Court of First Instance in Podgorica had properly applied this test in its judgment and acquitted the respondent party (Mr Nikolaidis). Unfortunately, the High and the Supreme Courts then overruled this judgment and made a very high award of compensation (about 12,000 EUR). Thus, instead of encouraging the lower courts to apply the standards of the Convention, the higher courts concretely discouraged them from so doing. The respondent then lodged a constitutional appeal before the Constitutional Court of Montenegro.

The respondent was a well-known novelist and journalist. He had written an article titled "the Devil's apprentice" which was published in a well-known weekly magazine and in which he had severely criticized the plaintiff, a world famous film-director, for his publicly expressed political views about the wars and the atrocities in former Yugoslavia and about the punishment of the main war criminals particularly in Bosnia and Herzegovina; his relationship with the Serbian nationalist regime; and his political, national and religious attitudes. The respondent used offensive and sharp language describing, inter alia, the plaintiff as "bad, ugly, and stupid". The High and Supreme Courts considered this defamation of the plaintiff in the press which severely insulted his honour and reputation. As noted above, he was awarded EUR 12,000 in compensation as well as legal costs.

The Constitutional Court of Montenegro applied, for the first time properly and completely, the test developed in the Court's case-law, for assessing whether the interference with the respondent's freedom of expression could be considered justified under Article $10 \S 2$ of the Convention, i.e. "in accordance with the law, pursuing a legitimate aim, necessary in a democratic society, proportionality of the aims pursued and means employed, sufficient and relevant reasons for the decision and severity of the punishment or compensation". Using this test, the Constitutional Court found that the High and the Supreme Courts did not properly apply the Convention in the particular circumstances of this case and thus violated the respondent's right to freedom of expression. The Constitutional Court quashed the judgment of the Supreme Court and remitted the case to the Court of First Instance in Podgorica. In doing so, the Constitutional Court relied particularly on the fact that

415 ECHR, no. 41158/09, 22 November 2011.

$416 \mathrm{Uz}-3$ - br. 87/09, of 19 January 2012. 
the plaintiff is a very well-known public person who made strong public statements concerning issues of great public interest and thus exposed himself to different and possibly strong public reactions. While the respondent indeed used sharp and offensive language, he expressed a series of value judgments with a strong factual basis in the course of an important public debate on a matter of great public interest. The Constitutional Court concluded that the respondent's sharp criticisms of the plaintiff's political and social attitudes did not overstep the level of permissible criticism from the point of view of Article 10 of the Convention. In finding that there had been a violation of respondent's right of freedom of expression, the Constitutional Court also took into consideration the severity of the award of compensation to the plaintiff (more than 40 times the average salary in Montenegro at the relevant time).

Recently, in a remittal, the Court of First Instance of Podgorica, having applied fully and properly the afore-mentioned test for compliance with Article 10 of an interference with expression, ruled in favour of the respondent. ${ }^{417}$ Until now this is probably the most significant influence of the Convention and the Court's case-law on the legal system and the courts' practice in Montenegro because, in a relatively short period of time after the Convention entered into force in respect of Montenegro, the domestic courts have started to apply those very sophisticated standards and procedures from the Court's case-law. It is also worth mentioning that, in the meantime, defamation has been decriminalised.

Last, but not least, in the last 2-3 years the Constitutional Court has improved the efficiency and the quality of its decision-making under the influence of the Court's judgments adopted against Montenegro. This is the case despite the fact that the Court has not yet declared the constitutional appeal to the Constitutional Court to be an effective remedy within the meaning of Article $35 \S 1$ of the Convention.

Article 149 of the Constitution of Montenegro ${ }^{418}$ provides that the Constitutional Court shall rule on a constitutional appeal lodged in respect of an alleged violation of a human right or freedom guaranteed by the Constitution, after all other effective remedies have been exhausted. It is noteworthy that the Constitution provides a wider corpus of rights and freedoms than the Convention, the former guaranteeing economic, social and cultural rights as well as minority rights. Section 48 of the Constitutional Court Act ${ }^{419}$ provides that a constitutional appeal may be lodged against an individual decision of a state body, an administrative body, a local self-government body or a legal person exercising public authority, for violations of human rights and freedoms guaranteed by the Constitution, after all other effective domestic remedies have been exhausted. Sections 49-59 of the same Act provide additional details about the processing of constitutional appeals. In particular, section 56 provides that, when the Constitutional Court finds a violation of a human right or freedom, it shall quash the impugned decision, entirely or partially, and order that the case be reexamined by the same body which rendered the quashed decision. This Act entered into force in November 2008.

Until 2010, no constitutional appeal had been accepted by the Constitutional Court. In 2010 it accepted 3 appeals out of the 337 lodged (0,89\%). In 2011, 16 of 475 appeals were accepted (3,37\%). In 2012 that court examined 505 appeals, accepting 13 (2,57\%). In total, until the end of 2012 the Constitutional Court had examined 1317 appeals out of which it had accepted 32 (2,43\%). Thereafter and until 1 June 2013, the Constitutional Court accepted 5 more appeals. ${ }^{420}$

In accepting those constitutional appeals, the Constitutional Court found that there had been violations of human rights and freedoms protected by the Constitution and the Convention. It quashed 25 judgments and decisions of the Supreme Court of Montenegro, 5 of the High Court, 3 of

417 http://sudovi.me/ospg

418 Published in the Official Gazette of Montenegro no. 1/07.

419 Published in the Official Gazette of Montenegro no. 64/08.

420 http://www.ustavnisudcg.co.me/slike/ustavnisud/praksa.htm 
the Courts of Appeal and 1 of a Court of First Instance. It also found violations without quashing the related acts in the 10 decisions ( 2 concerned decisions of the Court of First Instance, 5 of the High Court, 3 of the Court of Appeals). In these rulings, the Constitutional Court established violations of the right to an effective remedy, to personal liberty and security (the length and justification of detention on remand), to a fair trial, to be presumed innocent, to freedom of expression and to peaceful enjoyment of property. In a few of those constitutional appeals, the Constitutional Court has directly referred to the relevant articles of the European Convention and to the Court's case-law including Article $5 \S 1(c), \S 3$, and § 4; Article $6 \S 1$ and $\S 2$; Article 10; Article 13; as well as Article 1 of Protocol No. 1 to the Convention. ${ }^{421}$ Moderately and slowly, but in a relatively determined manner, the Constitutional Court of Montenegro has started to apply continuously the standards and principles developed by the Court's case law.

Additional case-law in respect of Montenegro reveals that the Court found that a constitutional appeal in Montenegro was not an effective remedy up to 2010 (see Koprivica v. Montenegro, cited above) and, further, that it was not an effective domestic remedy in respect of the length of proceedings, including the length of enforcement proceedings (see Boucke v. Montenegro ${ }^{422}$ ).

In particular, in Koprivica, the Court took into consideration that no constitutional appeal had been accepted prior to 2010 and that no judgment rendered in a constitutional appeal had been published before an unspecified date in 2010.

The Court has not yet pronounced definitively on the effectiveness of a constitutional appeal from 2010 or in respect of other complaints. When considering this issue the Court will certainly take into account the progress made in the work of the Constitutional Court described above as well as the relevant statistics including the number of the accepted constitutional appeals.

As to whether there have been legislative developments in Montenegro influenced by the Court's case-law, two crucial changes are to be noted.

In the first place, according to section 428a of the Civil Procedure Act, when the Court finds a violation of human rights or fundamental freedoms guaranteed by the Convention, the party to the proceedings may, within three months from the final judgment of the Court, seek that the impugned domestic decision be duly changed by the same first-instance court which issued it in the first place, if the said violation cannot be remedied in any other way except by re-opening of the proceedings. ${ }^{423}$ To date, two actions have been re-opened pursuant to this provision as noted above, the Garzičić and Koprivica cases.

Secondly, section 424 (6) of the Criminal Procedure Code provides that criminal proceedings where a final judgment has been adopted may be re-opened in favour of an accused where the European Court (or, indeed, another court established by a ratified international treaty) finds that human rights and freedoms have been violated during criminal proceedings and that the judgment is based on such violations, so long as any such re-opening can remedy the violation. ${ }^{424}$ Since the Court has not yet issued any judgment against Montenegro about criminal proceedings, the question of reopening a domestic action has not arisen.

As regards training the domestic judges, a Judicial Training Centre was established within the Supreme Court of Montenegro. In the last three years, amongst its other activities, this Centre organized more than fifteen seminars, round tables and workshops, mainly about Articles 5, 6, 8, 10 and 13 of the Convention, about the compatibility of the Criminal Procedure Code with the Convention and about the prohibition of discrimination (particular emphasis on the LGBT population

\footnotetext{
${ }^{421}$ Cited above in footnote 23.

422 ECHR, no. 26945/06, 21 February 2012.

423 Section 428a of the Civil Procedure Act (published in the Official Gazette of Montenegro no. 76/06).

${ }^{424}$ Section 424 (6) of the Criminal Procedure Act (published in the Official Gazette of Montenegro no. 57/09).
} 
and disabled persons). Various issues were discussed in these seminars such as the justification for detention, the presumption of innocence, equality of arms, defence rights etc.

These seminars were organized in cooperation with the AIRE Centre of London, Embassies of the US, UK and France, the OSCE Mission in Montenegro and the Foundation of Konrad Adenauer as well as non-governmental organizations from Montenegro such as the Centre for democracy and Human Rights (CEDEM) and the Human Rights Centre of the Faculty of Law in Podgorica. The seminars participants comprised judges of all courts in Montenegro as well as prosecutors from all levels. Unfortunately, no judges or members of the Registry of the European Court were amongst the lecturers and foreign experts participating those seminars. ${ }^{425}$

In cooperation with the Council of Europe's Directorate General of Human Rights and Rule of Law (Human Rights Policy and Development Department), two seminars were organized in the past two years, for the judges of the Supreme and the Constitutional Courts. There were four study visits to the Court and to the Council of Europe, also for the judges of the Supreme and Constitutional Courts. Certain judges and the members of the Court's Registry as well as the experts from the Council of Europe gave lectures during these visits. Moreover, during the visit of the former President of the Court, Mr Jean-Paul Costa, to Montenegro in September 2011, a very interactive Round Table was organized with the judges of the Supreme Court which dealt with Article 6 (the relevant case-law) with particular emphasis on the fairness of proceedings.

It can be concluded that these educational activities are extremely important to enable the Montenegrin judges to apply the standards of the Court. In the future, special attention should be paid to the construction of an even closer connection and dialogue between the Court and the highest courts in Montenegro, notably the Supreme Court and the Constitutional Court. The Court's Judges and the members of the Court's Registry should be involved on a regular basis in these activities.

${ }^{425}$ The lecturers included certain judges and experts from the USA, the UK and France and, most regularly, Nuale Mole from the AIRE Centre (London); Mr Zoran Pazin, the Agent of the Governemnt of Montenegro before the European Court of Human Rights; and Mr Sinisa Bjekovic, Head of the Human Rights Centre of the Faculty of Law. 


\title{
POLAND
}

\author{
Lech Garlicki* and Ireneusz Kondak ${ }^{*}$
}

\section{Introductory Remarks}

1. Poland's transition to democracy took place upon a long-lasting process of political and societal changes. The so-called "First-Solidarity" period (1980-1981) created foundation for rapid emergence of the civic society as well as for decline of the Communist Party role. Although the introduction of martial law (December 13, 1981) dramatically terminated this first democratization attempt, it was no longer possible to restore the old system of government. There is no need to refer to those historical events in a more detailed manner: as it is well known, the final act of the disintegration of the Communist system took place in 1989 and was marked by the Round Table Talks (February-March), constitutional amendment (April), parliamentary elections (June) and the creation of the Mazowiecki Cabinet (August).

Integration with Europe has always constituted one of the main priorities in the process of transformation, it was rightly perceived as the only way to ensure international security of Poland and its economic survival. The entry into the Convention system was regarded as an important component of the "European agenda". In October 1992, Poland joined the Council of Europe (which act also implied ratification of the European Convention on Human Rights). On January 19, 1993, the Convention entered into force in respect to Poland; additional Protocols, however, were ratified only later (on October 10, 1994 - Poland became bound by protocols no. 1 and 4; on November 1, 2000 by Protocol no. 6 and on March 1, 2003 - by Protocol; no. 7) and only partially (protocols 12 and 13 have not been ratified as yet).

Poland's membership to the Council of Europe delivered a political background for further integration with the Western world: in 1999, Poland joined the NATO Alliance and in 2004 was admitted to the European Union.

\section{Constitutional Premises - the Status of the Convention}

2. The new Constitution was adopted only in 1997. It meant that for almost 8 years the transition process has developed in a complicated constitutional environment: next to constitutional laws adopted after 1989, substantive portions of the old 1952 Constitution remained in force. The task of coordinating of those constitutional provisions became one of the priorities of the Constitutional Court. While the prolonged period of constitutional provisory gave rise to numerous disputes and difficulties, it also allowed more time for preparations of the new Constitution. This had quite beneficial effects as constitution-drafters had not only a hindsight of past mistakes but were also able to take advantage of the emerging Poland's presence in the European system. In particular, the drafters had to take into account that Poland had already ratified the European Convention and that there is no alternative but to adjust constitutional text to the requirements of the Convention. It was, therefore, not surprising that constitutional provisions on individual rights duplicated, as much as practicable, the language of the European Convention.

Nor was it surprising that the 1997 Constitution adopted quite open and friendly attitude towards international law as such. Poland has traditionally adhered to the dualistic approach to international law. In its classic version, it considered that international law form a system separated from domestic law and that therefore international legal obligations must be transformed by the internally competent body in order to be applicable domestically. On the other hand, international treaties, once duly ratified and published, entered into the domestic law as its components. 
The 1997 Constitution reiterated the traditional approach: international treaties have to be ratified in order to enter into the domestic law. The power of ratification remains with the President of the Republic (Article 133), but ratification of important treaties requires prior parliamentary approval (Article 89). At the same time, the Constitution - for the first time in the history of Polish constitutionalism - went beyond the regulation of ratification procedure and adopted some general rules as to the position of international law and supranational law in the domestic legal order.

Article 9 declares generally that "the Republic of Poland shall respect international law binding on it". This provision has a universal scope and refers not only to treaties, but also to all other sources of international law, in particular to generally recognized principles of international law, other norms arising from customary law, unilateral obligations, and binding norms adopted by international organizations ${ }^{426}$. Thus, Article 9 "expresses the principle of openness of the Polish legal order in respect to the norms of international law and establishes a presumption of automatic, even if only indirect, incorporation of those norms into that order" ${ }^{\prime 27}$. A similar interpretation has been adopted later by the Constitutional Court ${ }^{428}$.

3. The position of international treaties in the domestic legal order depends on the procedure of its adoption. A particularly elevated position is granted to treaties which were ratified by the President of the Republic upon a prior parliamentary statute authorizing ratification. It goes without saying that the European Convention belongs to that category.

A ratified treaty becomes, by virtue of its ratification, a "part of the domestic legal order and shall be applied directly, unless its application depends on the enactment of a statute" (Article $91 \mathrm{sec} .1$ of the Constitution). Article $91 \mathrm{sec} .1$ establishes, in a clear language, the principle of direct applicability of all ratified treaties. One of the consequences of that principle is that treaty provisions are regarded as conferring rights on individuals and, in consequence, may (and should) be applied by the courts and provide independent legal basis for the court judgments. However, if a treaty provision has not been formulated in a self-executing manner, courts (as well as other state authorities) must wait for its reformulation by the legislature.

Treaties ratified upon statutory authorization enjoy a suprastatutory rank in the domestic legal order. Article $91 \mathrm{sec} .2$ provides that such treaties "shall have precedence over statutes if cannot be reconciled with the provisions of such statutes". This is, probably, the most important part of the new constitutional arrangement as the ratification situates such treaties above ordinary statutes. In consequence, the courts are not only requested to directly apply the treaty provisions, but also are obliged to grant them priority over a conflicting statutory norm, whether prior or subsequent to the treaty. The courts should, at first, attempt to interpret the statute so as to avoid a conflict with the treaty and find a way of simultaneous application of both, the treaty and the statute. However, if such interpretation is logically impossible, the conflict must be resolved in favour of the treaty. There are two procedural ways opened for the courts to react to such conflict. On the one hand, Article 188 no. 2 of the Constitution establishes the jurisdiction of the Constitutional Court to review "the conformity of a statute to ratified international treaties whose ratification requires prior consent

${ }^{426}$ W. Czapliński: International Law and the Polish Constitution [in:] Constitutional Essays, ed. M. Wyrzykowski, Warsaw 1999, p. 298.

427 R. Szafarz: Międzynarodowy porządek prawny i jego odbicie w polskim prawie konstytucyjnym [International Legal Order and Its Reflection in the Polish Constitutional Law], in: Prawo międzynarodowe i wspólnotowe w wewnętrznym porządku prawnym [International and Community Law in the Domestic Legal Order, ed. M. Kruk, Warszawa 1997, p. 19.

428 "Article 9 expresses an assumption of the Constitution that, on the territory of Poland, a binding effect should be given not only to the acts (norms) enacted by the national legislature, but also to the acts (norms) created outside the framework of national law-making authorities. The Constitution opted for a multidimensional nature of the Polish legal system" (judgment of May 11, 2005, K 18/04, OTK 2005, no. 5A, item 49, III.2.1 - see Summaries of selected judgments of the Polish Constitutional Tribunal concerning EU law, Warszawa 2006). 
given by statute". Each and every court may refer such question to the Constitutional Court if relevant for the outcome of a pending case ${ }^{429}$. If the Constitutional Courts finds a statutory provision conflicting with the treaty, it annuls that provision with an immediate effect ${ }^{430}$. In practice, the challenges of such kind are regularly submitted to the Constitutional Court, particularly in reference to international human rights treaties ${ }^{431}$. On the other hand, there are opinions that the courts have also an independent power to refuse application of those statutory provisions that are in conflict with a treaty. However, the judicial practice in this area remains rather cautious.

On the other hand, international treaties (whatever was the procedure of their ratification) do not have precedence over the Constitution. The position of the Constitution as the highest law of the land finds procedural confirmation in Article 188 of the Constitution that establishes the competence of the Constitutional Court to "adjudicate the matters of the conformity of ... international treaties to the Constitution". This is the procedure of ex post review, in which the Constitutional Court assesses constitutionality of a treaty that already has been ratified and published and became a part of the domestic legal order ${ }^{432}$. If the Constitutional Court finds that a treaty is, indeed, unconstitutional, it cannot invalidate that treaty as such, but its judgment would bar application of that treaty in the domestic relations. It would also create an obligation of the competent authorities to take necessary steps to have the treaty amended or renounced ${ }^{433}$.

4. The European Convention and additional protocols, once duly ratified, were placed on the suprastatutory level in the domestic legal order. All public authorities are under an obligation to apply their provisions. In particular, the parliament has to ensure the compatibility of the ordinary legislation with the Convention (and, in parliamentary practice, questions of "conventionality" of draft legislation is regularly raised, often jointly with questions of its constitutionality).

The courts are bound to apply the Convention in deciding on individual cases and, in practical operation, parties regularly refer to the Convention. The Convention is understood as an aggregate of its text and of ECtHR's case-law.

On the one hand, it is obvious, under Article 46 of the Convention, that public authorities are bound to implement all final judgments in which Poland was found to be in violation of the Convention. Both, the criminal procedure and different administrative procedures provide for a reopening of cases affected by the ECtHR judgment. On the contrary, no right to reopening is explicitly provided in the Code of Civil Procedure and the Supreme Court excludes any possibility of reopening ${ }^{434}$.

On the other hand, the Strasbourg case-law plays more general role in the interpretation of the Polish law as far as the protection of individual rights is concerned. While this view is generally

\footnotetext{
${ }^{429}$ See Article 193 of the Constitution. The conformity of a statute to a treaty can also be assessed in the socalled abstract procedure, i. e. upon request of authorities enumerated in Article 191 of the Constitution.

${ }^{430}$ However, Article $190 \mathrm{sec} .3$ of the Constitution allows to the Constitutional Court to adjourn the annulation of an unconstitutional norm for a period not exceeding of 18 or 12 months (see, infra at 6).

${ }^{431}$ However, since many provisions of those treaties (first of all, of the European Convention on Human Rights) were reproduced almost verbatim in the text of the Constitution, applications to the Constitutional Court usually raise simultaneously questions of constitutionality and of conventionality of a statute. Not surprisingly, the Constitutional Court often prefers to focus on the former, strikes down the statute as unconstitutional and finds it not necessary to examine separately its conformity to the Convention.

432 The President of the Republic has also a power to submit treaty to the Constitutional Court before taking decision as to the ratification (Article $133 \mathrm{sec} .2$ of the Constitution). This procedure has not found any practical application as yet.

${ }^{433}$ See, in respect to the EU Treaties: judgment of the Constitutional Court of May 11, 2005 (K 18/04 - see Note 3) and judgment of the Constitutional Court of November 24, 2010, K 32/09, OTK 2009, no. 9A, item 108. 434 In 2011, however, the Constitutional Court, observed that the state's obligation to implement all ECtHR judgments requires the Parliament to adopt legislative modification of the Code of Civil Procedure and to provide, in clear terms, a possibility of reopening in some situations (decision of November 30, 2011, SK 16/10, OTK 2011, no. 9A, item 111, p. 1599).
} 
accepted by the judicial branch, judges often avoid making explicit statements that they are unconditionally bound by the case-law of the ECtHR. Instead, judges constantly confirm in their verdicts that this interpretation should be taken into account in the process of interpretation and application of the Convention or the relevant provisions of domestic law ${ }^{435}$. Already in 1995, the Supreme Court held that "from the moment of accession to the Council of Europe the case-law of the ECHR may and should be taken into account in the process of interpretation of the provisions of the Polish law" ${ }^{\prime 36}$. This position has been maintained and confirmed in the later jurisprudence of the Supreme Court as well as of the Supreme Administrative Court ${ }^{437}$. One of the most recent examples of this approach are the judgments of the Supreme Court related to the reopening of the social security proceedings concerning the right to an early-retirement pension in which the latter court relied explicitly on the Moskall ${ }^{438}$ jurisprudence of the ECtHR ${ }^{439}$. Also the Constitutional Court observed, on several occasions, that "although [under Article 46 par. 1 of the Convention] the ECtHR judgments are binding primarily on the defendant State in a particular case, all other Contracting States should take efforts to shape their systems of human rights protection in a manner which, in the fullest scope, takes into account standards elaborated in the case-law of the ECtHR" ${ }^{\prime 40}$. In its practice the Constitutional Court usually takes into account the relevant case-law of the ECtHR ${ }^{441}$.

Furthermore, the Constitutional Court has jurisdiction to review "the conventionality" of ordinary statutes as well as substatutory instruments. Decisions on "unconventionality" are final and regulation in question is annulled on the date of publication of the decision. In practice, arguments based on the Convention are often presented jointly with arguments based on the Constitution - it should not be forgotten that the text of the Constitution follows, to a considerable extent, the text of the Convention. In such cases, the Constitutional Court usually focus its decision on questions of constitutionality and, if a statutory provision is declared unconstitutional, there is no need to decide separately on its compatibility with the Convention. Thus, in most cases, references to the Convention (and to ECtHR case law) are used in the process of constitutional interpretation. However, there have also been cases in which the Court decided separately on unconstitutionality and on "unconventionality" of the reviewed legislation ${ }^{442}$. On very rare occasions, the Court reviewed only the question of "conventionality" and annulled the law as contrary to the Convention.

435 L. Garlicki, M. Masternak-Kubiak, K. Wójtowicz: Poland [in:] The Role of Domestic Courts in Treaty Enforcement. A Comparative Study, ed. by D. Sloss, Cambridge University Press 2009, p. 389-391.

436 Ruling of January 11, 1995, III ARN 75/94 (OSNP 1995 nr 9 item 106)

${ }^{437}$ For example, in the recent Resolution of 28 March 2013, III SPZP 1/13 the Supreme Court held that when examining a complaint about the unreasonable length of the proceedings a domestic court was required to take into account the overall length of the proceedings. This approach corresponds fully to the requirements of the Court's case-law.

438 In Moskal (judgment of 15 September 2009, app. no. 10373/05) the Court dealt with the complaint concerning the revocation of an early-retirement pension and found a breach of Article 1 of Protocol No. 1 to the Convention.

439 Judgment of January 9, 2012, III UK 223/10 in which the Supreme Court held that following the reopening of the social security proceedings the authorities should take into account the principles set out in Moskal. See also, judgment of September 21, 2010, III UK 94/09 and judgment of October 3, 2012, III UK 146/11.

440 Judgment of July19, 2011 (K 11/10, OTK 2011, no. 6A, item 60, p. 1008). See also: judgment of July 6, 2011 (P 12/09, OTK 2011, no. 6A, item 51, p. 820) and decision of October 4, 2011 (S 1/11, OTK 2011, no. 8A, item 87, p. 1415).

${ }^{441}$ A recent example is the judgment of 24 February 2010 (K 6/09, OTK 2010, no. 2, item 15, p. 199) in which the Constitutional Court upheld the constitutionality of the legislation reducing pensions of functionaries of the former communist State security authorities. The ECtHR in its subsequent decision Cichopek and Others $v$. Poland (14 May 2013, app. no. 15189/10) declared the case inadmissible, referring extensively to the findings of the Constitutional Court.

442 See, in particular the Lustration Judgment of May 11, 2007 (K 2/07, OTK 2007, no. 5A, item 48) 


\section{The ECtHR Case-Law in Polish Cases - Overview}

5. Poland counts as an active "producer" of individual applications. While, within the last years, other countries took a clear lead in the number of incoming applications, Poland still occupies a visible place in the Court's statistics.

In the summer of 2013 , Poland held $13^{\text {th }}$ position in terms of number of applications pending before the Court. There were 1750 Polish cases pending before various judicial formations of the Court ${ }^{443}$. The decrease in the general number of cases is due to the entry into force of Protocol No. 14 on 1 June 2010 which introduced simplified procedure before a single-judge formation in order to dispose of clearly inadmissible cases.

In terms of the issues arising in the applications against Poland it is a fairly constant feature that a large majority of these applications - about $90 \%$ - are declared inadmissible in a summary procedure.

The remaining cases, which are decided on the merits, concern a variety of issues under different Articles of the Convention. There exist certain groups of Polish cases which concern the following problems: 1) condition of detention cases, including lack of adequate medical care (Article 3); 2) excessive length of pre-trial detention (Article $5 \S 3$ ); 3) unreasonable length of judicial proceedings (Article $6 \S 1$ ); 4) revocation of the right to a certain type of an early-retirement pension (Article 1 of Protocol No. 1) and 5) reduction of retirement benefits of former officers of the state security apparatus (Article 1 of Protocol No. 1).

Other, less numerous, categories of cases concern 1) procedural obligations in cases of loss of life (Article 2); 2) police ill-treatment and the related procedural obligations (Article 3); 3) special regime for dangerous detainees (Article 3); 4) access to the Supreme Court by legally aided parties (Article 6 $\S 1) ; 5)$ custody and contact rights disputes (Article 8) and 6) defamation cases (Article 10).

In addition, there is a number of one-off cases raising meritorious issues under various provisions of the Convention.

In conclusion, it may be noted that Poland produces some relatively large groups of cases of which some reflect certain dysfunctionalities at the domestic level, for example the problem of overcrowding and poor sanitary conditions in prisons and some point to specific, country-related problems of dealing with the undemocratic past, such as the cases of retirement benefits of the former State security officers or lustration cases. Other cases are not related to large-scale systemic problems, but point to individual instances of infringement of the rights. It is fair to say that Poland, perhaps with the exception of the Broniowski case ${ }^{444}$, did not generate cases of grave human rights violations which would be suitable to establish significant precedents in the Court's jurisprudence.

\section{The ECtHR Case-Law in Polish Cases: Selected Areas and Effects on National Law}

\subsection{Criminal procedure}

Criminal procedure was one of the areas where the influence of the Convention standards was particularly strong after the collapse of the ancien regime in Poland. These standards are quite specific when it comes to criminal procedure and hence their direct impact on the domestic legislation. The Convention standards left clearly their mark on the amendments to the Code of Criminal Procedure in 1995 and the subsequent enactment of the entire new Code of Criminal Procedure of 1997 which entered into force in 1998. The drafters of the new legislation expressly

\footnotetext{
${ }^{443}$ As of 31 May 2013. The figure represents 1,5\% of all applications pending before the Court.

${ }^{444}$ Broniowski and others v. Poland (see, infra ...)
} 
intended to bring it into line with the Convention standards. The domestic courts also took part in this process. In some cases, even before the new legislation came into effect, the courts applied the Convention directly where the domestic law did not provide sufficient guarantees ${ }^{445}$.

In May 1995 the amendment to the Code of Criminal Procedure of 1969 established the right of a suspect to apply for a judicial review of the legality of his arrest in order to protect him against arbitrary deprivation of liberty and the right to seek compensation in cases of manifestly unjustified arrest $^{446}$. Subsequent amendment to the Code of Criminal Procedure of 29 June 1995 introduced another fundamental change ${ }^{447}$. It took away the power to impose pre-trial detention from the prosecutors and transferred it to the independent courts. This amendment resulted from the criticism of the existing legislation which was deemed incompatible with Article $5 \S 3$ of the Convention. The new Code of Criminal Procedure introduced further guarantees for persons suspected of having committed criminal offence. Its general premise, consistent with the Convention standards, was to subject decisions resulting in deprivation of liberty to judicial review.

In Niedbała (2000) the Court confirmed that a prosecutor did not meet the characteristics of "officer authorized by law to exercise judicial power" on account of his subordinate position to the Prosecutor General, who at the same time exercised the function of the Minister of Justice. Another particularity of the domestic law was the practice of keeping a person in detention on remand simply on the basis of the fact that a bill of indictment had been filed with a court and in the absence of any specific court order prolonging the detention. In Baranowski (2000) the Court held this practice to be in contravention of Article $5 \S 1$ of the Convention ${ }^{448}$. However, these deficiencies identified by the Court were already rectified by the 1995 amendment to the Code which transferred the competence to decide on issues of detention on remand to the courts.

Another problem concerned the lack of adversarial nature of the proceedings in which the court examined lawfulness of detention on remand ordered by the prosecutor. Neither the person charged with a criminal offence nor his lawyer could attend the court session at which the court examined the matter. This regulation was found to offend Article $5 \S 4$ in Niedbała (2000). This shortcoming was however put right by the relevant provisions of the new Code of Criminal Procedure of 1997. Henceforth the court was required to hear the person charged with the criminal offence before deciding whether detention on remand should be imposed and the lawyer of such person shall be notified of the date of a court session. In addition, any detention on remand had to be based on a specific court order.

The requirements of a fair trial contained in Article 6 of the Convention also influenced the new Code of Criminal Procedure. The new Code strengthened the rights of the defence by granting a suspect the right to contact a lawyer immediately after his arrest and the right to freely consult with a lawyer ${ }^{449}$. The rules related to anonymous witnesses, introduced first in 1995 and modified in the new Code, also took into account the standards established in the Strasbourg jurisprudence. The

445 In the resolution of 19 February 1997 (no. I KZP 37/96) the Supreme Court held that Article $5 \S 4$ of the Convention entitled a suspect to apply for judicial review of his arrest; published in OSNKW 1997, no. 3-4, item 21. In another interesting case the Supreme Court held that extradition of two Chinese citizens to China shall not be granted as it was not permissible under the Convention. It found that upon their return they may be subjected to treatment contrary to Article 3 and that they may not receive fair trial in China (decision of 29 July 1997, case no. II KKN 313/97).

${ }^{446}$ Amendment to the Code of Criminal Procedure of 29 May 1995. Journal of Laws no. 34, item 180.

${ }^{447}$ Amendment to the Code of Criminal Procedure of 29 June 1995. Journal of Laws no. 89, item 443. It entered into force on 4 August 1996.

${ }^{448}$ Similar conclusion was reached in Kawka (2001).

449 However, in Rybacki (2009) the Court found a breach of the applicant's defence rights (Article $6 \S 1$ with Article $6 \S 3$ (c)) where for a significant period of time (nearly 6 months) the suspect could not have had unsupervised contacts with his lawyer. This situation, however, was based on the provisions of the old Code of Criminal Procedure of 1969. 
Court appeared to confirm that the Polish regulation concerning anonymous witnesses complied with the Convention standards ${ }^{450}$. Lastly, the new Code of Criminal Procedure provided for an express possibility to reopen the domestic proceedings following a decision of an international body acting on the basis of a ratified international treaty (Article $540 \S 3$ ).

There were situations in which certain rules of criminal procedure needed readjustment following judgments of the Court. In one of the first cases decided against Poland (Belziuk, 1998) the Court found a breach of the fair trial guarantees when an acussed, who did not have a lawyer and was detained, was not allowed to be present at the appellate hearing which was attended by the prosecutor. At the relevant time the appellate court had an unlimited discretion in deciding whether the accused's presence at the appellate hearing was necessary ${ }^{451}$. The new Code of Criminal Procedure partly responded to the problem signaled in Belziuk, but the fully satisfactory solution to it came only with the amendment to the new Code in $2000^{452}$. Another issue was an arbitrary refusal of the prosecutor to grant a lawyer access to the investigation file in order to effectively challenge the lawfulness of detention on remand. The Court found a violation of Article $5 \S 4$ on this ground in a few cases against Poland ${ }^{453}$. In view of the lack of adequate response of the authorities to this issue, the Constitutional Court was required to intervene. In 2008 it disqualified the relevant provision of the Code of Criminal Procedure (Article $156 \S 5$ ) in so far as it allowed for arbitrary refusal of access to part of the investigation file which served to justify the prosecutor's application for imposition of detention on remand ${ }^{454}$. The judgment relied on the established case-law of the Court in this area and adopted a similar approach to the issue. In response to the judgment, the Code of Criminal Procedure was amended in $2009^{455}$.

In Ladent (2008) the Court identified a lacuna in the domestic law concerning the position of persons arrested on the basis of detention order issued in their absence ${ }^{456}$. In such cases the law did not provide for automatic judicial review of arrest and made it dependent on an application of the person concerned thus falling foul of the standard required under Article $5 \S 3$. The bill amending the Code of Criminal Procedure adopted by the Government in 2012 addresses this issue; however the legislative work has not yet started.

\subsubsection{Detention on remand}

The legislative reforms inspired by the Convention remodeled the criminal procedure as discussed above, in particular by strengthening the powers of the independent courts. However, certain problems persisted. One of them, which lead to many findings of a violation of the Convention, was much too eager application of detention on remand by the courts. The Court found a violation of Article $5 \S 3$ of the Convention in numerous cases against Poland on account of unreasonable length of detention on remand and, in particular, on account of failure to give "relevant and sufficient reasons" which could justify the periods in question. The scale of the problem was such that the Court decided to resort to a "pilot judgment" procedure to address the issue. It was also prompted by the Interim Resolution of the Committee of Ministers (2007) relating to the excessive length of detention on remand in Poland ${ }^{457}$.

In Kauczor (2009) the Court concluded that the significant number of cases against Poland concerning the issue of excessive length of detention on remand revealed "a widespread problem

\footnotetext{
450 Decision in Rybacki v. Poland (2007); but it was so far the only decision dealing with the issue.

${ }^{451}$ Article 401 of the Code of Criminal Procedure of 1969.

452 Amendments to the Code of Criminal Procedure of 20 July 2000.

453 See, for example, Migon (2002); Chruscinski (2007); Laszkiewicz (2008).

454 Judgment of 3 June 2008, K 42/07; OTK 2008, no. 5A, item 77.

455 Further readjustment is on the way; see proposal for the amendment of the Code of Criminal Procedure adopted by the Government in 2012 .

456 Similar issue arose in Piotr Nowak (2010).

457 It also had regard to the Memorandum of the Commissioner for Human Rights on the issue.
} 
arising out of the malfunctioning of the Polish criminal justice system" ( $\S 58$ of the judgment). Referring to the relevant statistical data, it found that the issue could be characterised as a "structural problem". In view of these findings, the Court called on the Government to adopt further general measures to put an end to the violation found. It should be noted that following the Kauczor decision the authorities decided to follow upon the Court's recommendations and in consequence the number of cases concerning this issue has decreased. Similarly, the number of judgments finding a violation in this respect has dropped in the light of the Government's policy to settle as many cases as possible or to have them struck out following a unilateral declaration.

In one case of a well-known businessman and a lobbyist, the Court was confronted with the allegation that his detention on remand was aimed not at securing the proper conduct of the investigation but served to persecute and abuse him and thus was contrary to Article 18 of the Convention (Dochnal, 2012). In obiter dictum the Court entertained some doubts as to the real intention of the authorities in the case, namely whether they meant to extract depositions from the applicant on sensitive political matters; however, it found that in the context of Article 18 mere suspicions as to the misuse of State powers, in the absence of incontrovertible and direct proof, were not sufficient.

\subsubsection{The right to examine witnesses against the accused}

The recurrent issue in Polish cases concerns the right to examine witnesses against the accused (Article $6 \S 3$ (d) of the Convention). It usually relates to complaints that the criminal courts relied on statements given by witnesses in the course of the investigation and where such witnesses became later unavailable to attend trial. As a result, the courts read their statements at trial and the accused had no opportunity to question these witnesses. Until Al-Khawaja and Tahery judgment of the Grand Chamber (2011) the Convention standard was "the sole and decisive rule" which meant that a conviction based solely or to a decisive extent on evidence of witnesses whom the accused was unable to question at any stage of the proceedings would be unfair. The Court applied "the sole and decisive rule" in few Polish cases with the result depending on the particular features of a given case ${ }^{458}$

Al-Khawaja and Tahery relaxed the existing standard by holding that the admission in evidence of statements given by absent witnesses - which constituted sole or decisive evidence against an accused - will not automatically result in a breach of Article $6 \S 1$ of the Convention. However, in such a case the Court would require sufficient counterbalancing factors (strong procedural guarantees) that permit a fair and proper assessment of the reliability of the evidence to take place.

The Court had already an opportunity to apply the Al-Khawaja test in four Polish cases. In Fafrowicz (2012) and Kostecki (2013) it found no violation where that the authorities made all reasonable efforts to locate one or more of the main prosecution witnesses and where their evidence was not, in any event, the only evidence against the applicants. In Chmura (2012) the Court also found no violation where the main prosecution witness was in fact heard not at trial but during a specially convened pre-trial hearing. In Chudy-Sternik (2013) the Court declared inadmissible the complaint that the victim of rape had not been heard by the trial court in the presence of the accused. It took into account that the statements of the victim were not the only evidence against the accused and the special context of sexual offences.

\subsubsection{Juvenile Justice}

Despite the passage of time the procedure applicable to juvenile offenders is still regulated by the 1982 Juvenile Justice Act. In Adamkiewicz (2010) the Court had an occasion to examine the

458 The Court concluded no violation in Gossa (2007), Biełaj (2010) and Jakubczyk (2011). The opposite was concluded in W.S. (2007), Demski (2008) and Kachan (2009). 
application of the Juvenile Justice Act and assess its compatibility with the guarantees of a fair trial. The Court found a violation of Article $6 \S 3$ (c) in conjunction with Article $6 \S 1$ of the Convention in relation to two issues. First, the authorities failed to provide a juvenile suspect with assistance of lawyer during the first six months of preparatory proceedings. Second, in the preparatory proceedings the authorities obtained incriminating statements from the juvenile suspect in the absence of his lawyer and those statements were subsequently relied on by the courts when reaching the verdict on the juvenile's responsibility. The circumstances of the case were fairly similar to Salduz v. Turkey (2008) which enabled the Court to find a violation on the basis of the principles established in that case ${ }^{459}$. Additionally, the Court found a breach of the violation of Article $6 \S 1$ of the Convention on account of the fact that the same judge of the family court had carried out the preparatory proceedings and subsequently participated in giving a decision on the juvenile suspect's responsibility. In such a situation the court could not have been considered impartial. In February 2013 the Government submitted to parliament a bill amending the Juvenile Justice Act which was prompted, inter alia, by the Court's decision in Adamkiewicz.

\subsubsection{Lustration}

The Court was confronted with the issue of lustration procedure in Poland and, in particular, with the lack of sufficient procedural guarantees for persons subjected to lustration. The 1997 Lustration Act provided that candidates for or holders of important public office were required to declare whether they had collaborated with the State security services of the communist regime. The law was equally applicable to judges, prosecutors and advocates. The veracity of those declarations was verified in court proceedings at the request of the specially established Commissioner of Public Interest. No legal sanctions were envisaged in case of declaring that a person had collaborated with the former security services. However, the finding that a declaration had been untrue entailed a dismissal of the person concerned from his or her office or barred the person from seeking the office.

The issue of lustration or, more broadly, of dealing with the heritage of the former undemocratic regimes in Central and Eastern Europe was not limited to Poland ${ }^{460}$. The Court did not contest the idea of lustration in general ${ }^{461}$; however, in Adamsons v. Latvia (2008), it established four general requirements ${ }^{462}$. Already, before Adamsons, the Court, in Slovak and Polish cases confirmed that the persons subjected to lustration should benefit from a full range of procedural guarantees 463 .

As far as Polish cases were concerned, the first issue to determine was the applicability of Article 6 $\S 1$ of the Convention to the lustration proceedings. In Matyjek (2007), having analysed the features of the lustration proceedings, the Court ruled that they were akin to the criminal proceedings and

\footnotetext{
459 A similar violation, but in the context of ordinary criminal proceedings, was found by the Court in Płonka (2009). In this case, relying on Salduz v. Turkey, the Court found a breach of Article $6 \S 1$ in conjunction with Article $6 \S 3$ (c) where the applicant, who was in vulnerable position on account of her alcoholism, was not provided with the assistance of a lawyer from the very first stage of police questioning and where the statements made during this questioning had a bearing on her conviction.

${ }^{460}$ Resolution 1096 (1996) of the Parliamentary Assembly of the Council of Europe on measures to dismantle the heritage of former communist totalitarian systems.

461 Decision Chodynicki (2008).

462 Firstly, the lustration law must meet the requirements of accessibility and foreseeability. Secondly, lustration procedure cannot exclusively serve the goals of punishment or revenge, since the prosecution of the guilty persons belongs to the sphere of criminal law. Thirdly, a domestic law providing for restriction of the Convention rights must be sufficiently precise to determine individual responsibility of each of the persons concerned and must contain procedural guarantees. Fourthly, the national authorities should bear in mind that lustration measures are temporary by nature and the necessity for restricting individual rights as a result of those measures diminishes with the passage of time.

463 Turek v. Slovakia (2006)
} 
hence the guarantees of a fair trial should be equally applicable to the lustration proceedings. The next step was to review the fairness of the lustration procedure in Poland.

In Matyjek (2007) and subsequent cases ${ }^{464}$ the Court concluded that the lustration procedure set out in the 1997 Lustration Act did not respect the principle of equality or arms between a person subjected to the procedure and the Commissioner of Public Interest. Interestingly, the Court in a certain way "overruled" the Polish Constitutional Court which in a number of decisions in principle upheld the constitutionality of the Lustration Act.

The allegations against a lustrated person were based on documents created by the former security services which were covered by official secrecy. Persons concerned had no, or very limited, access to those documents which restricted significantly their possibilities to defend themselves, while the Commissioner of Public Interest had unlimited access to the relevant documents prior to the institution of judicial proceedings. The Commissioner then enjoyed privileged position in the proceedings. At the stage of the judicial proceedings a lustrated person faced further restrictions since due to the nature of the documents the case-file could have been consulted only in a secret registry of a court and there was no possibility to make notes or photocopy documents from the case file. The cumulative effect of the above aspects of the Polish lustration procedure led the Court to conclude that the parties were not on equal footing and that the principle of fairness was not respected. In at least three cases the Supreme Court reopened the lustration proceedings following the judgments of the Court and instructed the lower courts to take on board the Strasbourg findings ${ }^{465}$ . In 2006 the original lustration procedure was significantly amended and the office of the Commissioner of Public Interest was abolished.

\subsection{Establishment of independent courts}

After the transition to democracy the independence of the judiciary became one of the principal objectives. This trend was inspired by the Convention and the traditions of the Western European democracies. It was reflected in the expansion of the scope of the courts' jurisdiction and the winding up of certain institutions inherited from the old regime, such as the boards for administrative offences (kolegia ds. wykroczen). For this reason very few problems reached the Court as the bulk of reforms were carried out domestically without the need for "corrective" impulse from Strasbourg.

One issue which found its way to Strasbourg concerned the status of judicial assessors (trainee judges). First, the Constitutional Court was seized of the issue. In its seminal judgment of 24 October $2007^{466}$, the Constitutional Court ruled that the provisions of the Organisation of Courts Act regulating the status of assessors were incompatible with the constitutional guarantees of judicial independence. It noted that the assessors were appointed and vested with judicial powers by the Minister of Justice, but at same time they did not have adequate safeguards against an arbitrary removal from the judicial office by the Minister. In its analysis the Constitutional Court relied considerably on Article $6 \S 1$ of the Convention and the Strasbourg jurisprudence related to independence of the courts.

When the complaints challenging the lack of independence of assessors reached Strasbourg, the Court could rely on the comprehensive analysis of the Constitutional Court which applied its own case-law. Not surprisingly, in Urban (2010) the Court concluded for similar reasons that the status of assessors did not meet the requirements of independence set out in the Convention ${ }^{467}$. At the same

464 Bobek (2007), Luboch (2008), Jalowiecki (2009), Rasmussen (2009), Górny (2010), Tomasz Kwiatkowski (2011), Moczulski (2011), Zawisza (2011), Mościcki (2011).

465 Rasmussen, Luboch and Matyjek.

466 Case no. SK 7/06; OTK 2007, no. 9A, item 108.

${ }^{467}$ For similar reasons of lack of independence from the executive the Court found a breach of Article $5 \S 3$ of the Convention in cases where a judicial assessor ordered detention on remand, see Mirosław Garlicki (2011) 
time the Court limited its finding to the specific Polish regulation and did not generally exclude the possibility that officials other than judges could exercise judicial powers, provided that the necessary guarantees of their independence had been put in place ( $\$ 52$ of the judgment).

An interesting aspect of the case concerned the possibility of reopening of the proceedings. The Constitutional Court excluded it having regard, inter alia, to the constitutional importance of the finality of rulings and legal certainty. The Court adhered to this analysis and ruled that its judgment did not require ordering the reopening of the domestic proceedings. It noted that the Constitutional Court had identified a structural problem and called for legislative action. The legislator followed this call by abolishing the institution of judicial assessors as of May 2009. It should be underlined that the issue of assessor was a very positive example of putting in practice the principle of subsidiarity and of cooperation between the Constitutional Court and the Strasbourg Court. The Urban ruling led to development of the practice where subsequent assessor cases in Strasbourg were struck out on the basis of a unilateral declaration from the Government acknowledging a breach of Article $6 \S 1$ of the Convention and pointing to the legislative reforms undertaken in response to the judgment of the Constitutional Court.

There were also certain cases in which non-judicial bodies heard the applicants' civil claims and their decisions could not have been challenged before a court ${ }^{468}$. In one such case the applicant association, the former user of an expropriated property which had been returned to the original owner, could not pursue a claim against the State Treasury for reimbursement of its expenditure on maintenance of the property ${ }^{469}$. In Woś (2006) the Court was confronted with a complaint of a former Second World War forced labourer who claimed that the Polish-German Reconciliation Foundation's refusal to award him compensation could not have been reviewed by a judicial body. The Court held that the exclusion of judicial review of certain decisions of the Foundation was incompatible with Article $6 \S 1$ of the Convention ${ }^{470}$.

\subsection{Unreasonable delays in judicial proceedings}

The problem of excessive delays in judicial proceedings was one of the recurrent issues in Polish cases. In Kudla (2000) the Court decided to take a firmer stand on the issue and found a violation of Article 13 in that the domestic law did not provide for a remedy against the excessive length of proceedings. The idea behind this approach was to "repatriate" this type of cases back to the domestic level and to put additional pressure on the Government to organise its judicial system in the way which ensures compliance with the right to have one's case decided within a reasonable time.

Poland's response to Kudla came in 2004 with the enactment of the Law on complaints about a breach of the right to a trial within a reasonable time. The Court considered that the remedy provided by the 2004 Act constituted an effective remedy and required the applicants to use it before filing their case in Strasbourg ${ }^{471}$. However, it soon became apparent that the 2004 Act was not always properly applied by the courts. For example, when examining the complaint of unreasonable delay, the courts did not take into account the overall length of the proceedings but only the period directly preceding the filing of the complaint. The courts also frequently considered

and Stoklosa (2011).

468 A similar issue was dealt with in Brudnicka (2005). There the Court found that the maritime chambers, which had ruled on the liability for a shipwreck, were not independent and impartial tribunals meeting the requirements of Article $6 \S 1$ of the Convention.

469 Zwiqzek Nauczycielstwa Polskiego (2004).

470 Interestingly, in response to Wos judgment, the Supreme Court revisited its long-standing earlier case-law and held that the civil courts had jurisdiction to hear claims against the Polish-German Reconciliation Foundation; see Resolution of 27 June 2007, III CZP 152/06.

471 Michalak and Charzynski decisions (2005). 
that they could not examine delays which occurred prior to the entry into force of the 2004 Act. In addition, even when the excessive delay was established, the awards made were very modest or none at all. In some respects, also the 2004 Act itself appeared to be deficient, for example by setting the maximum amount of compensation which could have been awarded at 10,000 Polish zlotys (2,500 EUR).

In response to the Court's criticism, the 2004 Act was amended in 2009472. The amended Act increased the compensation to 20,000 Polish zlotys (5,000 EUR) and established a minimum award of PLN 2,000 (500 EUR) which has to be made if the court concludes that an excessive delay occurred. Furthermore, the courts have to take into account the overall length of the proceedings. The guarantees of the 2004 Act were also extended to the pre-trial stage of the criminal proceedings.

The amended Act led to decrease in the number of cases concerning unreasonable length of proceedings. In addition, the Government adopted a policy of reaching friendly settlements in these cases or, in the absence of the applicant's consent, requested the Court to strike the case out on the basis of the undertaking made in the unilateral declaration. Despite all these efforts a smaller but still considerable number of cases from Poland continued to reach Strasbourg. In 2012 the Court decided to initiate a pilot judgment procedure in respect of this cases, pointing to persistent problems with the proper application of the 2004 Act (as amended), in particular with regard to the level of awards made by the courts ${ }^{473}$. The procedure in those cases is still pending before the Court. It is worth noting that in March 2013 the Supreme Court adopted a resolution addressing persistent problem in the application of the 2004 Act and instructed the courts to have regard to the overall length of the proceedings when examining the complaints under the said $\mathrm{Act}^{474}$.

\subsection{Conditions of detention}

Another human-rights problem which was „inherited” from the Communist regime was related to shortcomings in operation of the penitentiary system and, in particular, the conditions of detention. In Kudla (2000), the Court addressed the problem under Article 3 of the Convention and, for the first time, elaborated on those aspects of prohibited ill-treatment (see, infra ...). Since the mid-2000s, the Court began to decide on increasing number of Polish cases in which violations of Article 3 resulted, in the first place, from inadequate medical assistance provided in the carceral environment. On the other hand, the Court was less expeditious in deciding on general prison conditions, in particular on hardships resulting from overcrowding of penitentiary institutions. Nevertheless, Polish "overcrowding-cases" have been steadily accumulating and, as it was quite obvious that a vast majority of them would lead to violation judgments, there was also a growing pressure on the domestic authorities to deal with the matter. That was why the Court, albeit reluctantly, have waited until the position of the domestic courts became fully defined. In 2007 and 2008 respectively, both the Supreme Court and the Constitutional Court addressed the problem in a satisfactory manner. It prompted the political branches of government to relax repressiveness of the penal policies and, more or less in the same time, most of the old prison facilities were replaced by newly-constructed ones.

The Court reacted only in 2009 when, in two landmark judgments (Orchowski and Sikorski), it confirmed positions taken earlier by the Polish judiciary. It was clearly stated that overcrowding practices, once typical for the Polish penitentiary system, were incompatible with the Convention and that detention in an overcrowded cell gives rise to compensatory claims enforced before civil courts. The Court, deliberately, did not offer any clear guidance as to the space criteria of overcrowding. The CPT documents suggested the minimum of $4 \mathrm{~m}^{2}$, whereas the Polish regulation

\footnotetext{
472 Majewski (2005); Wyszczelski (2005), Kesiccy (2009).

473 Suchecki and others.

${ }^{474}$ Resolution of 28.03.2013, case no. III SPZP 1/13.
} 
required at least $3 \mathrm{~m}^{2}$. The Court left the matter open and put more emphasize on a cumulative approach under which overcrowding was assessed together with other parameters of detention.

While prison-condition-cases have not yet disappeared completely from the Polish docket, most of them are now considered before the domestic jurisdictions, at least as far as compensatory remedies are involved ${ }^{475}$. On the other hand, the Strasbourg Court has recently entered into a new aspect of prison conditions, namely into applications of so-called "special regime" to dangerous inmates. Already the first cases, decided in $2012^{476}$, indicated that Polish regulation was overbroad and too formalistic, leaving almost no room for assessment of individual situations. As the number of "special regime cases" ascends, the Court, as well as the Polish authorities, have still to find a solution of a general nature.

In brief, Polish prison condition cases may be regarded as an interesting example of cooperation between the Court and the domestic authorities, which resulted in a successful conclusion and in which domestic courts have played quite significant role. Nevertheless, even if some questions seem to be solved, at least in principle, it would be too optimistic to assume that those cases disappear entirely from the Strasbourg agenda. Prison condition cases are, by their nature, closely related to social dimension of human rights and, as long as some Member States continue to be more limited in resources than the others, also their prison systems continue to show differences.

\subsection{Abortion}

Regulation of abortion constitutes one of the most controversial areas in Polish politics and, since the 1997 decision of the Constitutional Court, abortion is permitted only in exceptional situations ${ }^{477}$. The Strasbourg bodies have always been very careful in intervening into the matter: for a very long time the Court decided not to go beyond the Commission decision in Bruggemenn and Scheuten (1977). It was only in 2007 when, in Tysiac v. Poland, the Court (addressing the problem of therapeutic abortion) changed its "policy of non-intervention". First of all, the Court accepted that abortion regulation gives rise to an interference with Article 8 rights. Furthermore, the Court held that in all situations in which the domestic law allows abortion, the authorities are under an obligation to ensure its availability in practice.

Tysiac was later confirmed in A., B. and C v. Ireland (2010). While, the Court reiterated that "Article 8 cannot be interpreted as conferring a right to abortion" (par. 214), it also held that once abortion has been permitted under the domestic law, "the legal framework devised for that purpose should be shaped in a coherent manner" (par. 249). The same approach was subsequently adopted in Polish cases dealing with abortion justified by an incurable disease of the foetus (R.R., 2011) and abortion justified by rape (P and S, 2012). In both cases, the Court criticized failings in the implementation of the Abortion Act and, in both cases, it held that not only Article 8 but also Article 3 had been violated.

In all three "Polish" abortion cases the Court indicated inadequacies and lacuna in the domestic regulations and administrative practices. Those suggestions, however, were not followed by the domestic authorities and remained largely without effect. Thus, the "abortion-jurisprudence" can be regarded as one of the few areas in which the ECtHR's position has not been properly complied with at the domestic level.

\footnotetext{
475 See: Łatak v. Poland (dec.) and Łominski v. Poland (dec.) adopted on 12.10.2010

476 Piechowicz and Horych judgmnets.

477 I.e. only if: 1. pregnancy endangers the mother's life or health; 2. prenatal tests or other medical findings indicate a high risk that the foetus will be severely and irreversibly damaged or suffering from an incurable lifethreatening disease; 3 . there are strong grounds for believing that the pregnancy is a result of a criminal act.
} 


\subsection{Democratisation process}

It is fair to say that generally Poland did its homework when it comes to putting democratic institutions and procedures in place. It is certainly not a country without some problem areas as indicated by certain judgments of the Court or more recent phenomena which need to be addressed by the authorities ${ }^{478}$. At the same time, after the transition to democracy even when the political power was concentrated at the hands of one party the existing instutions and procedures (free media, independent courts, civil society) were mostly capable of correcting excesses and resolving conflicts. The efficiency of domestic mechanism explains, at least in part, the lack of major cases from Poland addressing shortcomings of the democratisation process in Poland.

Nonetheless, the case-law of the Court points to certain deficiencies in the functioning of democratic institutions in Poland. The first area which should be mentioned is freedom of expression and, more specifically, a relatively large group of Polish cases concerning criminal defamation. It is relatively common in Poland that a politician, particularly of a local level, in response to a criticism voiced in the media would respond with a private prosecution, alleging that he (she) had been defamed. The Polish Criminal Code still provides that in case of defamation committed through the mass media (i.e. aggravated from of defamation) a journalist is liable to a fine, restriction of liberty or imprisonment not exceeding one year (Article $212 \S 2$ ). The Constitutional Court was confronted with the issue of constitutionality of this provision. However, in the judgment of 2006 it upheld its constitutionality, pointing in particular that protection of dignity and reputation by means of civil law alone would not be equally efficient as by means of criminal law ${ }^{479}$. As a result, the debate on the defamation continues and there is an on-going campaign initiated by the civil society to remove the offence from the statute book ${ }^{480}$. There is a strong argument that such provision does not have a place in a democratic society and that the possible media excesses should be curbed by civil law measures alone ${ }^{481}$. Yet, the established view of the Court is that in view of the margin of appreciation a criminal measure as a response to defamation cannot be considered disproportionate per se $e^{482}$. However, the sanction of imprisonment for a press offence will only exceptionally comply with the principle of proportionality, namely in cases involving hate speech or incitement to violence ${ }^{483}$

In this situation the Court receives complaints from journalists and local activists who were convicted on the basis of this provision. It is rare that in such cases domestic courts would impose a sentence of imprisonment which was likely to fail the test of proportionality established in the case${ }^{l a w^{484}}$ and in that sense perhaps the case-law influenced the recent domestic practice. Earlier, this was not evident. In Skałka (2003) the sentence of eight months' imprisonment for insulting a State authority (the court) was found disproportionate. In Malisiewicz-Gasior (2006) where the violation was found a suspended sentence of imprisonment for defamation was one of the elements taken in the assessment of the necessity of interference.

Other sanctions imposed by the courts (fine, order to make payment to a charity, obligation to publish a judgment) may not pass the test of proportionality either. Particularly, when the domestic courts fail to take into account other principles established in the Court's case-law such as enhanced protection of debate on issue of public interest, wider limits of acceptable criticism with regard to politicians, the need to carefully distinguish between statements of facts and value judgments, the

\footnotetext{
478 One of them is the rise of extremist nationalistic groups and the violence against the migrants.

479 Judgment of 30 October 2006, P 10/06; OTK 2006, no. 9A, item 128.

${ }^{480}$ Campaign initiated by the Helsinki Foundation for Human Rights and some journalistic organisations.

${ }^{481}$ M. O'Boyle "The opinions, separate and otherwise, of Judge Nicolas Bratza" in "Freedom of expression. Essays in honour of Nicolas Bratza."

482 Lindon, Otchakovsky-Laurens and July v. France [GC] 2007.

${ }^{483}$ Cumpana and Mazare [GC] (2004).

${ }^{484}$ Cumpana and Mazare v. Romania [GC] 2004.
} 
possibility of resorting to exaggeration and the requirement to have regard to the overall context ${ }^{485}$. Nonetheless, in some cases the Court found no violation in reference to the lack of professionalism and good faith of journalists even when reporting on issues of public interest ${ }^{486}$. The issue of special diligence becomes paramount in cases of civil liability of journalists ${ }^{487}$.

In Janowski (1999) the Grand Chamber of the Court found no violation of freedom of expression when the applicant had been convicted for insulting civil servants in the course of a heated exchange ${ }^{488}$ . The Court's ruling was not unanimous and the majority's approach was criticised by legal writers ${ }^{489}$. However, the case was important for establishing that civil servants were an intermediate category between politicians and private individuals with regard to the limits of acceptable criticism. When acting in an official capacity they are subject to wider limits of permissible criticism but at the same time they have to be protected from offensive attacks in the exercise of their duties ${ }^{490}$. This principle was subsequently referred to in numerous judgments of the Court ${ }^{491}$.

The Court strongly emphasised the enhanced protection of freedom of expression during electoral campaign before national or local elections. In Malisiewicz-Gqsior (2006), a classic defamation case, the domestic courts failed to take into account that the criticism of a politician was voiced by his political opponent during an electoral campaign when the freedom of political debate was of paramount importance. In Kwiecien (2007) the Court dealt with a special expeditious procedure available to candidates standing for local elections who allege that information disseminated during electoral campaign was untrue ${ }^{492}$. It observed that the availability of such summary procedure during the period of electoral campaign served the legitimate goal of ensuring the fairness of electoral process. At the same time it was necessary to ensure that the procedural guarantees afforded to the parties to such proceedings should not be unduly restricted at the price of an expeditious examination of election-related disputes ( $\$ 55$ of the judgment $)^{493}$.

In Wizerkaniuk (2011) the Court had to assess whether the 1984 Press Act providing for a criminal sanction for breach of a journalist's obligation to obtain the authorisation of the interviewed person prior to the publication of the interview was compatible with Article 10. It disqualified the relevant provisions of the Press Act as disproportionate since they provided for automatic imposition of criminal sanctions irrespective of the subject-matter of the interview, the accuracy of the reproduction of the statements or the position of the person concerned. In reaching this conclusion the Court had regard to the fact that the said provisions were adopted in 1984 and remained on the statute book despite profound political and legal changes occasioned by the country's' transition to democracy ${ }^{494}$.

The freedom of assembly was not seen as a problematic issue with one notable exception concerning the Mayor of Warsaw's refusal in 2005 to hold an equality march on the ground that the organisers had failed to submit a "traffic organisation plan". The march took place despite the ban. A

485 Cases in which the Court found a violation of Article 10 with reference to these aspects of the proportionality test: Sokolowski (2005), Malisiewicz-Gasior (2006), Dabrowski (2006), Dlugolecki (2009), Kurlowicz (2010), Lewandowska-Malec (2012), Jucha and Zak (2012).

${ }^{486}$ Ciesielczyk (2012), Ziembinski (2012).

${ }^{487}$ For example, Wołek, Kasprow and Leski (dec.; 2007); Kania and Kittel (2011); Semik-Orzech (2011).

488 Janowski, judgment of 21 January 1999, app. no. 25716/94.

489 The case was decided by a majority of 12 to 5 with Judges Wildhaber, Bratza, Rozakis, Bonello and

Casadevall dissenting.

490 Paragraph 33 of the judgment.

491 For example: Thoma v. Luxembourg (2001); Nikula v. Finland (2002); Yankov v. Bulgaria (2003); Pedersen and Baadsgaard v. Denmark (2004); Raichinov v. Bulgaria (2006); July and SARL Libération v. France (2008).

492 Similar procedure exists in respect of parliamentary elections.

493 Kita (2008) concerned similar issue.

494 In May 2012 a group of deputies submitted a bill which decriminalises the offence at issue in the Wizerkaniuk case; however the amendment has not yet been passed. 
second-instance administrative authority quashed the ban as unlawful. However, its decision was given long after the date of the planned march. Prior to the date of the march the Mayor declared in an interview that he would ban any demonstration aimed at propaganda of homosexuality. In Baczkowski and Others (2007) the Court found a breach of Article 11 of the Convention on the ground that the interference with the freedom of assembly was declared unlawful in appeal proceedings and thus was not prescribed by law. It further relied on the judgment of the Constitutional Court which declared certain provisions of the Road Traffic Act, which had been applied in the applicants' case, incompatible with the constitutional guarantees of freedom of assembly ${ }^{495}$. The Court felt it necessary to reaffirm its earlier case-law that democracy did not simply mean that the views of the majority had to always prevail and that the fair and proper treatment of minorities had to be ensured by the authorities. Their positive obligations to secure the effective enjoyment of the freedom of association and assembly was particularly important for persons holding unpopular views or belonging to minorities because they were more vulnerable to victimisation ( $\S 64$ of the judgment). In the same case the Court found a breach of Article 13 of the Convention in that the authorities were not obliged by any legally binding time-frame to give their final decisions before the planned date of the demonstration. Lastly, the Court found a breach of Article 14 in conjunction with Article 11 on account of the Mayor's declarations which could have affected the decision-making process and, consequently, impinge of the applicants' freedom of assembly. It appears that the judgment has not been yet properly executed in so far as the provision of expeditious appeal procedure is concerned ${ }^{496}$.

The Court was also confronted with the legislative ban for municipal guards to join a political party. The similar ban was applicable to other similar services, such as the army, police, border guards, customs service, etc. In Strzelecki (2012) the Court, following the decision of the Constitutional Court ${ }^{497}$ , found the ban to be compatible with the freedom of association guaranteed by Article 11 and justified by the legitimate concern to ensure political neutrality of the public service. It also considered that the ban in question did not affect the essence of the freedom of association.

In one case concerning the prohibition of the establishment of an association advocating some antiSemitic goals there was a need for the "corrective" action of the Court. The Court decided that the applicants could not rely on Article 11 of the Convention and that the ban on formation of their association was justified under Article 17 of the Convention since the association's activities would have been contrary to the text and spirit of the Convention ${ }^{498}$.

\section{The Influence of the Case-Law and the Democratization Process}

1. The case-law of the Strasbourg Court has always played an important role in the process of democratic transformation. In the initial period, when the foundations of the new system had to be elaborated, this case-law served rather as an indirect source of inspiration. Until 1993 Poland was not formally bound by the Convention and also later, it took several years before the Court began to produce judgments in Polish cases.

Thus, the Convention (and the case-law of ECtHR) constituted one of the external inspirations for both the legislative reforms and the judicial practice. Even before the formal ratification, the Convention was regarded as an attractive instrument and all those who decided on the course of transformations have always had it in mind. Furthermore, until 1997, there was no updated catalogue of constitutional rights and liberties. The Convention was, therefore, regarded as an

\footnotetext{
495 Judgment of 18 January 2006, K 21/05; OTK 2006, no. 1A, item 4.

496 Legislative amendments are still on-going; See, communication from the Government to the Committee of Ministers concerning the execution of the Baczkowski and Others judgment of February 2012.

497 Judgment of 10 April 2002, K 26/00; OTK 2002, no. 2A, item 18.

498 W.P. and Others, decision of 2 September 2004, app. no. 42264/98.
} 
indication how the old constitutional provisions should be interpreted and modified and also how the provisions of the new Constitution should be drafted (see, supra ...).

But, it should also be kept in mind that the Convention was not the only source of inspiration. First of all, in the beginning of 1990s, the ECtHR case-law was not as developed as it became today. Particularly, in respect of political pluralism and electoral regulations, more attractive information could be found in political documents of the Council of Europe (and, in this perspective, the role of the Venice Commission deserve a special recognition). Secondly, as Poland was aspiring for the EU membership, numerous questions of its political system, judicial organization and individual rights have been intensively scrutinized by different EU bodies and institutions. It seems that, in practice, the EU inspiration has played more important and more direct role in convincing Polish authorities to keep within the European standards. Finally, the supranational level of inspiration, albeit important, co-existed with inspirations arriving from the developed democracies, first of all - from France and Germany. This inspiration has always been well rooted in the Polish legal and intellectual tradition and found almost immediate expression in the judicial practice (e.g. in respect of the interpretation of the Rechtsstaat-clause by the Constitutional Court ${ }^{499}$ ) as well as in scholarly opinions. And it should not be forgotten that the conceptual origins of the Strasbourg case-law also followed the same source of inspiration.

2. The autonomous role of the Strasbourg case-law began to gain more visibility only after the ECtHR had begun to decide on Polish cases in a systematic and frequent manner. Some examples of its influence on the Polish legal system were presented in the previous chapters. It seems that there were two areas: judicial procedure (including problems of judicial independence) and freedom of (political) expression in which this influence played the most prominent role. But, it should be observed, once again, that analysis of the Strasbourg case-law form a regular component of judicial preparation of every important case concerning individual rights. While most of those cases are decided in principal reference to the constitutional provisions, the case-law of the ECtHR can be regarded as background information which helps judges in interpretation of the domestic law.

The informational (inspirational) function of the Strasbourg jurisprudence has always remained in the foreground. Another important function is legitimization, particularly attractive in politically sensitive cases. For example, in the 2007 Lustration Case (see, supra ...), the Constitutional Court not only referred to the ECtHR's case-law but also decided separately on the "conventionality" of the lustration legislation. Hence, the Constitutional Court shifted a part of responsibility to the supranational level.

Quite instructive are also examples of "intellectual cooperation" between Polish Courts and the ECtHR. It took the most visible form in the Polish "pilot judgments" (see, infra ...). In Broniowski, even the timing was significant: it was not accidental that the first Constitutional Court's decision on unconstitutionality was adopted almost on the same day as the ECtHR's decision of admissibility. In rent-control-cases, decisions of both the ECtHR and the Constitutional/Supreme Court were adopted in an alternating order ${ }^{500}$. In prison condition cases (see, supra ...), the ECtHR waited until the Constitutional Court had decided on unconstitutionality of the domestic legislation and until the Supreme Court had confirmed the availability of compensatory remedies. In the Assessors Case, the ECtHR not only waited until the Constitutional Court struck down the existing legislation, but also duplicated the Constitutional Court position as to non-retroactivity of their judgments. Another example of such "intellectual parallelism" was seen in cases on electoral law: the ECtHR (albeit in non-Polish cases) and the Constitutional Court decided that the principle of democracy excludes, in principle, that important modification of electoral regulations is made in too close proximity to the

${ }^{499}$ See M. F. Brzezinski, L. Garlicki: Judicial Review in Post-Communist Poland: The Emergence of a Rechtsstaat (1995) 31 Stanford J. Int'I L., 35-42

500 See L. Garlicki: Cooperation of Courts. The role of supranational jurisdictions in Europe, I*CON 2008, no. 34. 
date of election ${ }^{501}$. However, as questions like political pluralism or fair elections but exceptionally gave rise to genuine political controversies in Poland, the ECtHR has never been offered a chance to intervene in a direct manner.

The same observation applies to other issues of the democratization process. As regards equality before the law, the Baczkowski case ${ }^{502}$ can be regarded as the most prominent input of the Strasbourg Court. On the other hand, however, the ECtHR's judgment was adopted only after the Constitutional Court and the Supreme Administrative Court had taken their decisions and, to large extent, confirmed positions taken by the domestic courts.

In brief, the process of Polish transformation appears to be quite successful also in the area of democratization and pluralism. There have been numerous examples of the ECtHR's inspiration and advise and, on several occasions, the domestic authorities, in the first place the supreme judicial bodies, were more than happy to linked their decisions to standards elaborated on the European level. But, as the number of Polish cases has always been limited on this field, the influence of the Strasbourg jurisprudence had mostly indirect nature. And its role must be seen upon more a general context of "European influences" on Poland, in particular, influences based on tradition of contacts with countries like France or Germany, influences arriving from the political bodies of the Council of Europe as well as from within the European Union.

\section{6. "Polish Case-Law" and Its Impact on the General Jurisprudence of the ECtHR}

1. Polish cases only rarely represented more than boring average of the incoming applications. As most of them dealt with length of procedure or/and length of detention there offered only limited chances for creation of meaningful precedents. Hence, while the "Polish jurisprudence" played often an important role in the domestic developments, it was usually focused on application of judgments adopted in respect of other countries.

Clearly, it were two Polish "pilot judgments" (Broniowski, 2004-2005 and Hutten-Czapska, 2006) which can be regarded as the most important contribution to the general case-law. Broniowski was the very first case in which the Grand Chamber expressly referred to the concept of pilot judgments. "This concept is focused on three basic ideas. Firstly, "pilot-judgments" may be adopted only in reaction to "a systemic situation", i. e. to a situation which affects a large number of people and which results from the state of legislation or/and from the widespread administrative practices in the respondent State. Secondly, the task of "pilot-judgments" is not only to identify the shortcomings in the State's legislation or/and administrative practice, but also to hold that the State is requested to undertake general remedial measures and, exceptionally, to indicate more concrete steps to be taken by the State. Finally, each "pilot judgment" constitutes not a mere recommendation but a commandment, at least in respect of those its components that were included into the operative part of the Court's judgment. The Court's competence to adopt "pilotjudgments" results from Article 46 of the Convention. The Court assumes that the States' obligation to respect and to execute all final judgments may include an obligation to take general measures of legislative or administrative nature" ${ }^{\prime 503}$.

\footnotetext{
501 Compare the ECtHR's judgments in Tanase v. Moldova (2010) and Ekoglasnost v. Bulgaria (2012) with the Constitutional Court's judgments of November 3, 2006 (K 31/06, OTK 2006, no. 10A, item 147, p. 1540-1541) and of July 20, 2011 (K 9/11, OTK 2011, no. 6A, item 6, p. 1056-1057).

502 See supra, ... In this case, the 2007 ECtHR's judgment was preceded by a judgment of the Constitutional Court (January 18, 2006, K 21/05, OTK 2006, no. 1A, item 4).

503 L. Garlicki: Broniowski and After: On the Dual Nature of "Pilot Judgments: [in:] Human Rights - Strasbourg Views. Liber Amicorum Luzius Wildhaber, Kehl 2007, p. $177 \mathrm{ff}$.
} 
There is no need to elaborate on the matter. It may be sufficient to note that the both Polish pilotjudgments were also successfully implemented in the domestic legal system and, therefore, could be regarded as an effective way to address general problems. Since Broniowski, the practice of pilot judgments has developed into a well-recognized component of the Strasbourg case-law. Sometimes the Court duplicates the Broniowski model and orders the general measures in the operative part of its judgments. Sometimes, the Court chooses more flexible form and addresses the general questions only in separate paragraphs on Article $46^{504}$.

2. Kudla v. Poland (2000) represent another Polish case of general importance. This case delivered a twofold message. First, in respect of Article 6, the Court addressed the problem of delays in judicial procedure and, for the first time, requested the Polish authorities to consider general measures to improve the operation of the domestic courts. While, in the Polish perspective, Kudla is regarded as one of the most important precedents (see, supra ...), in general perspective it simply developed the position taken earlier by the Court in the Italian cases. Secondly, in respect of Article 3 , the Court (without finding a violation) addressed the problem of prison conditions and, for the first time in the Strasbourg case, elaborated on "indirect ill-treatment", i.e. non-deliberate illtreatment resulting from general conditions of detention. This was regarded upon the background of human dignity and, in the subsequent general jurisprudence, Kudla has always been regarded as the leading precedent in the matter.

\section{Conclusions}

1. After twenty years of Poland's presence in the Convention system, the "Polish" case-law of the Strasbourg Court have developed into a vast body of judgments and decision. The high input of applications resulted, in the end of the first decade, in considerable delays in the adjudication process. The $14^{\text {th }}$ Protocol allowed more expeditious disposal of clearly inadmissible cases and, recently, most of the backlog cases has been taken care of. Also, the number of decisions became equal (or, even, higher) than the number of the incoming applications. But, effectiveness had its price and the Court had no alternative but to become more selective in deciding which applications would be decided on the merits. Hence, the traditional concept of the ECtHR as "a court of individual petition" gave way, to a considerable extent, to its function as a "European Constitutional Court".

Although the bulk of Polish cases was concentrated on not very interesting matters (length of procedure, length of preliminary detention), some of them gave rise to more general precedents on that field. The Court realized that several Polish problems are of systemic nature and should be assessed in the overall perspective of democratic transformation. That was why the Court was quite active in developing the concept of "pilot judgments" and to applying it, in different versions, to problems which called for general legislative or judicial measures. Cases concerning "classic" areas of democracy and pluralism were less numerous, nevertheless, the Court was able to address several problems of freedom of expression and, to a lesser extent, freedom of association.

The scarcity of the case-law on democracy and pluralism was, in part, due to the successful evolution of transformation process in Poland. And when the political changes resulted in more acute dangers, the domestic courts (in the first place - the Constitutional Court) appeared sufficiently independent to be able to enforce respect for European standards.

2. The analysis of the "Polish" case-law of the Strasbourg Court allows to organize its role around four principal functions:

The "inspirational function" was the one which was most regularly visible in the Strasbourg jurisprudence. The Court often indicated problems, solutions and situations which, while incompatible with Convention standards, have survived in legal regulations as well as in judicial practice. In most cases, the Court's position has been duly taken into account by the domestic

${ }^{504}$ See, e. g. Polish judgments in Kauczor (supra...) as well as in Orchowski and Sikorski (supra...) 
authorities. Particularly important was, in this perspective, the practice of cooperation between the highest segments of the Polish judiciary (the Constitutional Court, the Supreme Court and the Supreme Administrative Court), which, in most cases, were open towards inclusion of the Strasbourg case-law into their jurisprudence. The inspirational function was, paralelly, visible in regard to political processes of democratization, but it seems that the Court jurisprudence has played here less direct role as in the case of some other "new democracies".

The "legitimizing function" constituted another use of the Strasbourg case-law the domestic courts. Sometimes, particularly in situations where Polish courts were confronted with delicate political matters, it could be quite attractive to refer to the ECtHR precedents as binding components of the "law" (it should be recalled that the Convention occupies quite elevated position within the domestic legal system). Thus, "the Strasbourg argument" was invoked to show that a particular interpretation is not just a whim of a domestic court, but has a solid basis in a well-established (and binding) European precedent. The 2007 Constitutional Court's judgment on lustration represented the most prominent example of such legitimization.

The "corrective function" is always present in the Strasbourg jurisprudence and, in the first place, can be regarded as a necessary consequence of the right of individual petition. In other words, each violation judgment adopted by the ECtHR calls for correction of an injustice that had happened on the domestic level. This function gains a particular prominence in regard of systemic problems (systemic violations) and it overlaps there with the inspirational function.

The "confrontational function" enters into play when the Strasbourg case-law collides with positions taken and maintained on the domestic level. It may lead to a prolonging conflict, particularly where none of the partners may be ready to revise its position. Such situations, sometimes experiences by the "new" as well as by the "old" democracies, are dangerous for the entire functioning of the Convention system and counterproductive for effective protection of individual rights. Poland does not count among the producers of those conflicts. The only "frontal collision" with the position of the Constitutional Court was related to some aspects of the Press Act (see above) and could hardly be regarded as symptomatic. ${ }^{505}$

505 Wizerkaniuk v. Poland (judgment of 5.July 2011, in which four out of seven judges filed concurring opinions). It seems worth to note that also the Constitutional Court was not unanimous in its judgment and the ECtHR confirmed the position of the dissenting judge. 


\title{
RUSSIA
}

\author{
Anatoly I. Kovler*
}

\section{European Convention on Human Rights in Russia: 15 years after 506}

5 May 2013 marked 15 years since the Convention for the Protection of Human Rights and Fundamental Freedoms $\mathrm{s}^{507}$ entered into force on the territory of the Russian Federation.

When ratifying the Convention by the Federal Law of 30 March 1998, the State Duma sent a clear signal that as a signatory to the Convention the Russian Federation recognises the jurisdiction of the European Court of Human Rights as binding in matters of interpretation and application of the Convention and the Protocols thereto in case of breach by the Russian Federation of the provisions of the compacts if committed after they become binding upon the Russian Federation (Article 1 of the Federal Law of 30 March 1998, No 54-FZ, "On ratifying the Convention for the Protection of Human Rights and Fundamental Freedoms and Protocols thereto»).

It looks like the disputes over whether European Court judgments are «binding» or "recommendatory» for the signatory governments have petered out though the banners of "legal sovereignty» do come up now and again. It appears that a much more fruitful effort would be to make a sort of intermediate report on what Russia has gained by joining the Convention, first of all in terms of an emergent legislative framework for implementing on a national level the provisions of the Convention, of this a true hallmark of European civilisation, putting it without any exaggeration.

Any anniversary provides an opportunity for a progress review in keeping with the anniversary. For the writer of these words, the anniversary is all the more significant because it coincides with his completion of his mission as a European Court judge, elected in respect of the Russian Federation in September 1999. Thirteen years of «insider's view» of the process of grafting the Convention's provisions on the tissue of the Russian legal system provide grounds to voice opinions binding on no one other than the author. I make no secret of being akin to a prospector who keeps panning in an attempt to obtain even a handful of coveted precious yield. In a recent interview, I gave to the International Justice journal, I have already said that it is much easier to criticise than to think positively ${ }^{508}$. And most importantly, with no responsibility... Yet significantly it was during the crisis years that a new verb appeared in the French language positiver - to think positively. Nothing venture, nothing gain...

In the context of this anniversary, it would not come amiss to remind the reader that Russia did not join the Convention system as a poor cousin. Unlike a number of «new democracies», which kept rewriting their constitutions to the standards of the Council of Europe as interpreted by Venice Commission pundits or dusted off constitutional relics of the past, Russia showed Europe its 1993 Constitution, which enshrined a rather impressive list of rights and freedoms for its citizenry. As an attendee at the 1993 Constitutional Assembly, I can say that this list is unique in that the Constitution defines, as its distinctive feature, a number of rights and freedoms by negating the practice of so-called socialist democracy:

«A person, his rights and freedoms are the supreme value» (Article 2); «a citizen of the Russian Federation may not be stripped of his citizenship or denied the right to change it» (Article $6 \S 3$ ); «... [the Russian Federation] recognises and protects private, public, municipal and other forms of ownership on an equal basis» (Article $8 \S 2$ ); «no ideology may be imposed as the state ideology

\footnotetext{
506 This article is a revised version of the article published by the Russian journal "Human Rights. CaseLaw of the European Court of Human Rights", 2013, No.6.

507 Hereinafter referred to as the Convention.

508 Persona grata. Interview with Anatoly Kovler // International Justice, 2013, 1(5) - in Russian.
} 
or binding ideology» (Article $13 \S 2$ ); «everyone may freely leave the Russian Federation» (Article

$27 \S 2$ ); «... censorship is prohibited.» (Article $29 \S 5$ ).

- one can go on listing examples of the new human rights framework being established.

In terms of preparation for the integration into the Convention system, however, it was also important to lay the international-law basis for this integration. Thus, Article $17 \S 1$ of the Constitution, which opens Chapter 2, "Rights and freedoms of the person and citizen», proclaims:

"The Russian Federation recognises and guarantees human and civil rights and freedoms according to the universally recognised principles and norms of international law and in accordance with this Constitution».

This primacy of universally recognised principles and norms of international law is enshrined in the well-known provision of Article $15 \S 4$; what is more - and we reiterate this - this Article is not in the "small print» of the constitutional text but at the heart of the most central Chapter I «Constitutional framework». Moreover, the fathers of the Constitution dispelled any doubts:

«If an international treaty of the Russian Federation lays down rules at variance with those provided by the law, then the rules of the international treaty shall apply».

It is obvious that in the context of Article $15 \S 4$ «law» is a generic notion of the legal system.

It is noteworthy that the Resolution of the Plenum of the Supreme Court of the Russian Federation of 10 October 2003, which will be discussed below, explains to the courts of general jurisdiction the concepts in Article $15 \S 4$ :

"The universally recognised principles of international law should be understood to mean the fundamental binding norms of international law, which are accepted and followed by the international community of countries in general and which may not be disobeyed».

The interpretation, we admit, is quite in keeping with the spirit of the well-known Martens clause.

Ibid:

«A universally recognised norm of international law should be understood to mean a rule of conduct, accepted and observed by the international community of countries in general as legally binding».

Whereas Article $46 \S 1$ of the Constitution guarantees to everyone judicial protection of his rights and freedoms, $\S 3$ of the same Article vests the Russian citizen with certain international legal capacity:

«Everyone is entitled under the international treaties of the Russian Federation to seek redress from international bodies for the protection of human rights and freedoms once all available domestic remedies have been exhausted».

So, 5 years before to Russia's integration into the Convention system, the constitutional legal framework already met all the conditions of such integration in terms of international-treaty law. The above provisions of the Constitution of the Russian Federation were consistent with both the Statute of the Council of Europe and the provisions of the Convention, particularly its Preamble and Article 1 «Obligation to respect human rights».

A greater challenge was to render the current legislation compliant with the criteria for membership in the Council of Europe. It so happened that I served for two years on a panel of independent experts to evaluate this compliance. In the voluminous final report ${ }^{509}$ experts,

509 Европейская Конвенция о защите прав человека и основных свобод и правоприменительная практика Российской Федерации (сравнительный анализ). Русская версия. [The European Convention for the Protection of Human Rights and Fundamental Freedoms and case-law of the Russian Federation (comparison study). Russian-language version.] M., 1997 / The compatibility of Russian 
both Russian and European, emphasised the urgent need for a statutory moratorium on the execution of death sentences as a first step towards the abolishment of capital punishment. It was also recognised that the statutory provisions governing the imposition of the state of emergency needed an overhaul. A 10-day period of pre-trial detention was held to be excessive for detention without bringing a formal charge against a detainee. The very procedure of detention was noted to feature arrangements at variance with Article 5 of the Convention. The experts also recommended making the regulatory framework of elections more accessible, providing a clearer statutory scope for peaceful meetings and demonstrations, streamlining the registration of printed and audio-visual media outlets etc. In all, the expert panel made some forty final recommendations with a direct bearing on the exercise of the civil rights enshrined in constitutional law and in the relevant legislation. Some of those recommendations were taken on board in the course of active law-making in the following years, while the rest are still hanging fire judging by the numerous applications to the European Court.

Even before joining the Council of Europe, namely after the enactment of the 1993 Constitution, there was a surge in legislative activity, which dramatically changed the legal order in Russia and the legal status of an individual. There should first of all be mentioned the development and enactment of new civil and criminal codes, the codes of civil and criminal procedure, the enforcement proceedings law, laws on non-governmental organisations and political parties in their original version, and a raft of electoral laws. As a member of working groups put together in the so-called "boisterous nineties" to develop draft laws, I can bear witness that all bills without exception were vetted for compliance with the international standards and Russia's international commitments in place. It looks like this procedure is no longer followed at all times, judging by the content and quality of some laws...

At the same time, it does not take a rocket scientist to see that applying enacted laws in particular circumstances proved an uphill struggle on the ground. It was here, at the coalface, that the European standards came in handy as a universal scale of values to measure national realities. The highest courts of the Russian Federation - the Constitutional Court, the Supreme Court and the Supreme Commercial Court - made a significant contribution to implementing the principle of direct application of the international-law norms by domestic courts, as well as provision of general and specific remedies in compliance with European Court judgments.

Here is a number of examples:

\section{Constitutional Court of the Russian Federation}

An example of a general remedy with practical implications for specific relief as well as individual remedies is a provision in the Code of Criminal Procedure of the Russian Federation, in place since 1 July 2002, which gives the option of quashing final court judgments, judgments and decisions and reopening criminal proceedings upon discovery of new evidence, which was deemed to include the establishment by the European Court of a breach of the Convention's provisions by a court of the Russian Federation in its criminal proceedings (Article $413 \S 4$ (2) of the Criminal Procedure Code of the Russian Federation). The enactment of this provision was preceded by a Ruling of the Constitutional Court of the Russian Federation of 2 February 1996 in a constitutionality test of a number of articles of the RSFSR Criminal Procedure Code, where the Constitutional Court holds, based on its interpretation of Article $46 \S 3$ of the Constitution (the right of citizens to appeal to international human rights bodies), as follows: this provision

«means that a decision of international authorities may result in a re-examination of specific cases by highest courts of the Russian Federation, and therefore gives the latter a mandate to

Federation Law with the requirements of the European Convention on Human Rights. English version. Strasbourg. 1997. 
reopen cases for the purposes of changing the previous decisions rendered therein, including by a supreme domestic judicial instance ${ }^{510}$.

It would be an exaggeration to take such an evolution of the approach to the judgments and decisions of the European Court as a purely «Russian achievement» (such changes in domestic legislation have taken place in many member States of the Council of Europe), but progress is obvious.

The Constitutional Court of the Russian Federation constantly refers in its rulings to the Convention and takes into account the legal positions of the European Court (incidentally, this is a two-way process, and the European Court in its judgments on Russian applications validates its reasoning more often than not by citing decisions of Russia's supreme courts, first of all the Constitutional Court ${ }^{511}$ ). What is at issue here is not politesse, but resolution of specific problems facing the courts and the legislator. For example, the Constitutional Court held on more than one occasion the provisions of a number of laws to be non-compliant with both the Constitution and the Convention. In particular, this approach is reflected in its Ruling of 17 February 2000 on the unconstitutionality of the part of Article 377 of the Code of Criminal Procedure that deals with lack of an explicit requirement for the attendance of the concerned party at the proceedings of the court hearing his cassation appeal or petition for supervisory review of the case. The European Court has already rendered several dozen judgments addressing this problem, as yet not fully resolved. In strict compliance with Article 413 of Criminal Procedure Code referred to above, the Supreme Court of the Russian Federation sends back for retrial cases found by the European Court to fall short of fair trial. Moreover, an expensive but rather effective system was set up across the nation to provide a video link between the courts and the serving convicts the cases against whom are heard under a cassational or supervisory review procedure, although, judging by the judgment of the Grand Chamber of the European Court of 2 November 2010 in the case of Sakhnovskiy v. Russia (application no. 21272/03), there are still problems with the provision of the right to defence.

In its Ruling of 5 February 2007, the Constitutional Court of the Russian Federation has sent an unequivocal message to the legislators and the law-application officials alike:

«... the decisions of the European Court of Human Rights $<. . .>$ are an integral part of the Russian legal system, and as such must be taken into account by the federal legislator in regulating social relations and by the law-application authorities when applying the relevant law provisions ${ }^{512}$.

For a long time, civil procedural law lacked a provision to mirror the provisions of Article 413 of the Criminal Procedure Code and Article 311 of the Code of Commercial Procedure for a retrial upon newly discovered evidence, which the legislator made to include judgments of the European Court finding violations of the rights of an individual in domestic trials. But Article

510 Ruling of the Constitutional Court of the Russian Federation of 2 February 1996 on the matter of constitutionality test of Article $371 \S 2$ (5), Article $374 \S 3$ and Article $384 \S 2$ (4) of the RSFSR Criminal Procedure Code in connection with complaints from the citizens K.M. Kulnev, V.S. Valuyev, Yu.V. Lukashov and I.P. Serebrennikov (section 7).

511 See, e.g: Pyrikov Ye.G. and Musukayev B.Kh., Правовые позиции Конституционного Суда Российской Федерации в постановлениях и решениях Европейского Суда по правам человека [Legal positions of the Constitutional Court of the Russian Federation in judgments and decisions of the European Court of Human Rights] (2007-2008). Review // Права человека. Практика Европейского Суда по правам человека [Human Rights. Case-Law of the European Court of Human Rights]. 2009, No 6.

512 Ruling of the Constitutional Court of the Russian Federation of 5 February 2007, No 2-P, «On the matter of constitutionality test of the provisions of Articles 16, 20, 112, 336, 376, 377, 380, 381, 382, 383, 387 and 389 of the Civil Procedure Code in connection with an enquiry from the Cabinet of the Republic of Tatarstan, complaints from the open joint-stock companies Nizhnekamskteftekhim [Nizhnekamskneftekhim] and Khakasenergo, as well as complaints from a number of persons", section $2.1 \S 2$ of the Ruling. 
392 of the Code of Civil Procedure had no such provision, and yet civil litigation accounts for the lion's share of cases before domestic courts. What is more, Article 392 of the Code of Civil Procedure as amended by the Federal Law of 4 December 2007, No 330-FZ, was edited to cut a reference to the European Court, but not to the Constitutional Court of the Russian Federation, from the draft law that was ready for enactment and that was assimilated by the legal community and the media - a sort of a "gift» to mark the anniversary of the State Duma's denial of ratification of Protocol No 14 to the Convention in December 2006... Russian citizens, however, seem to have already acquired the taste of defending their statutory rights using all legal remedies available.

A number of citizens whose rights were found by the European Court to have been violated sought redress through judicial channels, including by supervisory appeal against the decisions rendered in their cases, but met with no success - and then they filed with the Constitutional Court a challenge to entire Chapter 42 of the Code of Civil Procedure «Re-examination of court decisions and determinations and supervisory court presidium rulings that have become final upon newly discovered evidence».

The Ruling of the Constitutional Court of the Russian Federation in this case ${ }^{513}$ had a lot of public response just on account of the unorthodox position of the Constitutional Court of the Russian Federation: on the one hand, it stated that Article 392 of the Code of Civil Procedure in terms of constitutional law does not contravene the Constitution; on the other, an adequate redress for a rights' violation found by the European Court of Human Rights necessitates bringing the procedure for the review of final judgments in line with «fundamental legal principles of fairness and equality ${ }^{514}$. Here the Constitutional Court had to tread on thin ice, for the European Court made it plain that it was against supervisory review of civil cases as being at variance of the principle of legal certainty, with no departures from this principle allowed other than by way of exception to correct a fundamental error in the proceedings. But this ruling is of major importance because of its motivation and result. First, the Constitutional Court once again went on record decisively stating:

"Because the human and civil rights and freedoms recognised in the Convention for the Protection of Human Rights and Fundamental Freedoms are essentially the same rights and freedoms that are enshrined in the Constitution of the Russian Federation, confirmation of violations thereof by the European Court of Human Rights and Constitutional Court of the Russian Federation, respectively - on account of the common nature of these bodies and their purpose - assumes the availability of a single institutional mechanism for the execution of their decisions for the purposes of full restitution» (section $3.3 \S 2$ of the Ruling).

Given its position on this "single institutional mechanism", the Constitutional Court ordered the legislator to close the legislative gap in respect of European Court judgments:

«<...> federal legislator is required to $<\ldots . .>$ amend the Code of Civil Procedure of the Russian Federation in order to enable review of final court judgments where the European Court of Human Rights finds a breach of the Convention for the Protection of Human Rights and Fundamental Freedoms by a court of general jurisdiction in the adjudication of a specific case from which the applicant appealed to the European Court of Human Rights» (section $3.5 \S 4$ of the Ruling).

\footnotetext{
513 Ruling of the Constitutional Court of the Russian Federation of 26 February 2010, No 4-P, «On the matter of constitutionality test of Article $392 \S 2$ of the Civil Procedure Code of the Russian Federation in connection with complaints from the citizens A.A. Doroshok, A.Ye. Kot and Ye.Yu. Fedotova».

${ }^{514} \mathrm{~A}$ review of this ruling of the Constitutional Court of the Russian Federation is provided in the article: M.A. Filatova Исполнение постановлений Европейского Суда по правам человека в свете постановления Конституционного Суда Российской Федерации от 26 февраля 2010 года [Compliance with the judgments of the European Court of Human Rights in light of the ruling of the Constitutional Court of the Russian Federation of 26 February 2010] // Human Rights. Case-Law of the European Court of Human Rights, 2010, No 4.
} 
As for the applicants themselves, the Constitutional Court has held that the court rulings in their cases shall be subject to review in the prescribed manner.

This ruling is also important in that it reflects a growing convergence of the positions of the Constitutional Court of the Russian Federation and the European Court of Human Rights on the interpretation and application of the principles and standards in the protection of human rights. The aberration (this is what I believe the situation should be called) in the case of Konstantin Markin v. Russia, where the European Court was out of line in criticising the position of the Constitutional Court on a sensitive issue of the entitlement of servicemen to a long parental leave should be regarded as the exception that proves the rule. The European Court's rejection of the criteria of quantitative "representation" of political parties for the purposes of their registration and re-registration in the case of Republican Party of Russia $v$. Russia (the European Court judgment of 12 April 2011) is again essentially a "conflict of interpretations", a phenomenon not infrequent among courts at different levels ${ }^{515}$. Judgments of both courts are still full of references to the legal positions of each other so that the rumours of a "conflict» between them are indeed a manifest exaggeration.

\section{Supreme Court of the Russian Federation}

Because it is the courts of general jurisdiction that traditionally bear the brunt of adjudicating conflicts in society and protecting rights of citizens, the very first judgments of the European Court of Human Rights on applications against Russia came to grips with the problems of Russian justice system, be it failure to enforce court judgments (the case of Burdov v. Russia), length of proceedings in the case (criminal proceedings in the case of Kalashnikov v. Russia), breach of the principle of legal certainty as a result of repeated reviews of cases in a supervisory procedure (the case of Ryabykh v. Russia), etc. Eventually those problems grew into problems that the European Court has been increasingly describing as systemic. It therefore comes as no surprise that the Supreme Court of Russia became concerned about the implementation of the Convention already at an early stage of Russia's integration into the Convention system.

The increasing role of the courts of general jurisdiction in the implementation of the provisions of international law at the domestic level are laid down in the Resolution of the Plenum of the Supreme Court of the Russian Federation of 10 October 2003. Based on the provisions of Article $46 \S 1$ of the Constitution, which deal with judicial safeguards for human rights and freedoms, the Resolution explained to the courts that pursuant thereto as well as to the provisions of Article $15 \S 4$, Article $17 \S 1$, and Article 18 of the Constitution human rights and freedoms are directly applicable within the jurisdiction of the Russian Federation according to the universally recognised principles and norms of international law, as well as the international treaties of the Russian Federation. The Resolution suggested to the courts:

«As a signatory to the Convention for the Protection of Human Rights and Fundamental Freedoms, the Russian Federation recognises the jurisdiction of the European Court of Human Rights as binding in matters of interpretation and application of the Convention and the Protocols thereto in case of breach by the Russian Federation of the provisions of the compacts if committed after they became binding upon the Russian Federation $\langle\ldots\rangle$. That is why the courts must apply the above Convention with due regard to the case-law of the European Court of Human Rights to avoid any breaches of the Convention for the Protection of Human Rights and Fundamental Freedoms. <...> Execution of judgments affecting the Russian Federation involves, where necessary, the government's undertaking to take individual measures aimed at redressing the violations of the human rights enshrined in the Convention and the consequences of these breaches for the applicant, as well as general measures to prevent recurrence of such breaches.

515 Kovler A.I. Слухи об остром конфликте Европейского Суда и Конституционного Суда Российской Федерации, мягко говоря, преувеличены [Rumours of a bitter conflict between the European Court and the Constitutional Court of the Russian Federation are somewhat exaggerated] // Zakon [Law], 2012, No 2. 
The courts must act within their jurisdiction in such a way so as to honour the government's commitments arising from the Russian Federation's participation in the Convention for the Protection of Human Rights and Fundamental Freedoms» ${ }^{516}$.

The Supreme Court also deemed it necessary to expound the terms «trial within a reasonable time», "periods of detention», "degrading treatment» and a number of other key concepts of the European Convention in keeping with European Court judgments .

The Supreme Court has also laid down procedures for advising Russian judges on the case-law of the European Court, including the publication of collected decisions and judgments of the European Court in the Russian language ${ }^{517}$. Two specialised periodicals in Russian were launched: "Bulletin of the European Court of Human Rights" (since 2003) and "Human Rights. Case- Law of the European Court of Human Rights" (since 2006). A new one, "International Justice", has been published since 2011. Some regional periodicals on human rights are also launched.

Later on, the Supreme Court handed down a number of other important Resolutions expounding to the courts of general jurisdiction the legal positions of the European Court of Human Rights. I will name but a few of them, for they are regularly cited by the European Court in reviewing the applicable law in its cases $^{518}$. For example, in its Resolution of 24 February 2005, the Supreme Court has explained to the lower courts:

«In accordance with Article 10 of the Convention for the Protection of Human Rights and Fundamental Freedoms and Article 29 of the Constitution of the Russian Federation, which guarantee everyone the right to freedom of thought and speech, as well as freedom of the media, and the position of the European Court of Human Rights, when hearing personal and business defamation cases, courts should differentiate between verifiable statements of facts and value judgments, opinions or convictions not covered by the scope of judicial protection under Article 152 of the Civil Code of the Russian Federation inasmuch as, being an expression of a subjective opinion and views of the defendant, they cannot be verified as true» (section 9).

By the time when this Resolution was adopted, the European Court had already rendered a number of judgments on a breach of Article 10 of the Convention «Freedom of expression», in respect of journalists being sued for criticism of local authorities, so that the Resolution could not have come at a more opportune time. In an apparent attempt to allow for the sensitivity to criticism of certain bureaucrats who had requested that courts mete out exemplary punishments to the "presumptuous» journalists, the Supreme Court expanded on its guidelines:

"The courts should bear in mind that in accordance with Articles 3 and 4 of the Declaration on Freedom of Political Debate in the Media, enacted 12 February 2004 by the 872 nd session of the Committee of Ministers of the Council of Europe, politicians seeking public endorsement ipso facto consent to become a focal point for public political debate and criticism in the media. Public officials can be subjected to criticism in the media over their performance in office because this is necessary for public scrutiny of and accountability for the way they exercise their powers and authority» (ibid.).

\footnotetext{
516 Supreme Court of the Russian Federation. The Plenum Resolution of 10 October 2003, No 5, "On application by general jurisdiction courts of universally recognised principles and norms of international law and the international treaties of the Russian Federation».

517 Let us name the publications in the first years of the Convention's applicability to Russia [all in Russian]: European Court of Human Rights. Selected decisions. Volumes 1-2. M., 2000; European Court of Human Rights. Selected judgments 1999-2001 and commentaries. M., 2002; The European Convention. Article commentaries. M., 2003.

518 Resolution of the Plenum of the Supreme Court of the Russian Federation No 3 of 24 February 2005, "On legal precedents in personal and business defamation cases»; Resolution of the Plenum of the Supreme Court of the Russian Federation No 22 of 29 October 2009, «On the practical application by courts of restrictive measures in the form of detention, bail and house arrest»; Resolution of the Plenum of the Supreme Court of the Russian Federation No 11 of 14 June 2012, "On the practical aspects of criminal extradition proceedings in courts».
} 
The educational orientation of this precept is evident.

The Resolution of 29 October 2009 was adopted for a purpose, too: the number of the European Court judgments on Russia's breach of Article 5 of the Convention «Right to liberty and security", due to courts ordering pre-trial detention, left and centre as virtually the only restrictive measure overshot one hundred and was still rising. In that Resolution, the Supreme Court mentions Article 5 of the Convention only once, but the whole tenor of the document is in keeping with the spirit of European Court judgments:

"Detention may not be chosen as a restrictive measure where other, milder restrictive measure can be applied» (section 2)

- this is the original premise of the Resolution.

In its voluminous text, the Supreme Court keeps driving home the message that has become the core tenet of the European Court's legal position: the choice of restrictive measure must take into account without fail the individual characteristics of the person accused of a crime and not only just the seriousness of the charges brought. The Supreme Court details the applicability of bail and house arrest as measures ensuring the suspect's cooperation with the investigation and his court appearance.

In its Resolution of 14 June 2012, the Supreme Court responds to the European Court judgments concerning extradition of foreigners to the «risk countries». Referring to the provisions of the European Convention on Extradition of 15 October 1975 and the provisions the European Convention on Human Rights, as interpreted by the European Court, the Supreme Court draws the attention of the courts that the conditions and grounds for denial of extradition are set out not only in the Criminal Procedure Code of the Russian Federation, but also in the international treaties of the Russian Federation:

«Pursuant to Article 2 of the Convention for the Protection of Human Rights and Fundamental Freedoms, as interpreted by the European Court of Human Rights, and Article 11 of the European Convention on Extradition, a person may not be subject to extradition where the crime for which extradition is sought is punishable by death penalty in accordance with the law of the requesting state unless the state gives such assurance. Which the Russian Federation considers sufficient that the death penalty will not be carried out» (section 11).

The Supreme Court also points out that extradition may be refused where there are risks that the person to be extradited may be subjected in the requesting state not only to torture but also to inhuman or degrading treatment or punishment (section 12).

One year later the Supreme Court adopted the Resolution of 27 June 2013 on the implementation of the European Convention by the ordinary courts. After the reference to the subsidiarity principle and the doctrine of margin of appreciation it insists once again on the adequate implementation of the ECHR's judgments concerning the Russian Federation. The erga omnes character of the Court's case-law concerning other countries is also emphasised. The Resolution analyses some typical violations of the Article 6 procedural guaranties by Russian courts and possibilities of redress. The attention of national courts is drawn to the necessity to allow a just satisfaction to the victims of violations of the Convention comparable to the European Court's case- law.

\section{Supreme Commercial Court of the Russian Federation}

In its Circular of 20 December 1999, the Supreme Commercial Court of the Russian Federation detailed the requirements of Article 6 of the Convention «Right to a fair trial», and Article 1 of Protocol No 1 "Protection of property», as interpreted in light of the European Court's caselaw, and ordered the lower Commercial courts to take these requirements into consideration when adjudicating claims ${ }^{519}$.

${ }^{519}$ Supreme Commercial Court of the Russian Federation. Circular No S1-7/SMP of 20 December 1999 $-136 / 240-$ 
It must also be noted that there were no major problems in inserting into the Code of Commercial Procedure Article 311 to provide for a review of cases in the event that the European Court finds a violation of applicants rights in an Commercial procedure. The system of Commercial courts efficiently and timely overhauled the entire system of Commercial proceedings to meet international standards and the principle of legal certainty, putting in place full-fledged appeal and cassation courts, with the Supreme Commercial Court having sole authority to review cases in strictly defined categories. This, incidentally, enabled the European Court to recognise the current Commercial review proceedings as an effective remedy, required to be exhausted on a national level prior to filing an application at Strasbourg (see decisions on the admissibility of applications from Galina Kovalyova et al. [Kovaleva and Others v. Russia], (decision of 25 June 2009) and Obshchestvo s Ogranichennoy Otvetstvennostyu Link Oyl SPb [OOO «Link Oil SPB» v. Russia] (decision of 25 June 2009). This is largely the reason why the European Court sees few, if any, filings from Commercial proceedings. It is true though that some link it not so much with the efficiency of domestic remedies as with the very nature of economic disputes, incompatible with the long waiting list at Strasbourg - time is money! Be that as it may, the system of Commercial courts has indeed assimilated rather quickly such «innovations» of the European Court as award of nonpecuniary damages to legal entities or the use of proportionality criterion for the government's interference with the exercise of the right to property ${ }^{520}$.

With a view to ensuring consistent application by Commercial courts of the provisions of Article 311 of the Code of Commercial Procedure, the Plenum of the Supreme Commercial Court of the Russian Federation adopted a resolution of 12 March 2007, "On applying the Code of Commercial Procedure of the Russian Federation in reviewing final court rulings upon newly discovered evidence», where it included among the grounds for a review of court rulings a violation of the applicant's rights found by the European Court in the hearing of a specific case by an Commercial court.

Therefore, all three supreme courts of the Russian Federation have made efforts to have the domestic courts, legislators and law-application officials implement the provisions of the Convention. I understand the position of the authors and commentators who find that those efforts are inadequate, that they fall short of countering what is usually referred to as "a travesty of justice». But for some reason one is put in mind of the fable about two mice in pitchers of milk - the one that survived had churned milk into butter and climbed out...

My review would be incomplete if I failed to mention another two parties to this process of implementing the European Convention.

\section{Prosecutor General of the Russian Federation}

The Prosecutor General of the Russian Federation has adopted his own approach to notifying the European Court's opinions to the prosecutors of Russian Federation regions and equalstatus prosecutors at specialised prosecutors' offices - Circulars.

In response to the European Court's human rights judgments that find violation of civil rights by prosecutors' authorities in the course of investigative activities, as well as in other aspects of prosecutors' offices activities, the Prosecutor General of the Russian Federation sends out guidelines in the form of circulars, whose number is difficult to ascertain ${ }^{521}$. Two of the above

520 Neshatayeva T.N. Решения Европейского Суда по правам человека: новеллы и влияние на законодательную и правоприменительную практику [Decisions of the European Court of Human Rights: innovations and legislative and law-application impact]. M., 2013.

521 Let us name by way of illustration certain summarizing documents of recent years:

- Circular of 17 May 2009, «On the need for stricter oversight of investigation in light of judgments of the European Court of Human Rights»;

- Circular of 31 March 2010, "Review of the practices of the European Court of Human Rights in rendering decisions in connection with violation of Article 3 of the Convention for the Protection of 
circulars deserve individual attention, though the rest can be safely called "landmark» too. The circular of 15 September 2010 was only a month ahead of the intermediate report of the Council of Europe on police abuses in Russia ${ }^{522}$ is a symbolic coincidence, evidencing mutual concern over the situation in the run-up to the reform of the Russian police. The document of the Council of Europe paints a comprehensive picture of a variety of breaches of the Convention, with scrupulous references to European Court judgments; the recommendations are couched in explicit but diplomatic language. The Circular from the Prosecutor General also lists European Court judgments, specifying the breaches noted therein. But the tone is, naturally enough, that of the Prosecutor's fiat:

«<...> upon discovery of such practices [injuries - A.K.] arrange comprehensive measures aimed at establishing the circumstances in which the applicants sustained injuries <...>. Notify the irregularities described to your staff and demand that they be prevented in future».

The Circular of Mr S.G. Kekhlerov, a Deputy Prosecutor General of the Russian Federation, of 21 December $2010^{523}$ is by nature of a review and opens with the words:

«In adjudicating complaints originating in the Russian Federation with parties to criminal proceedings, the European Court of Human Rights <...> normally identifies the same breaches of the provisions of the Convention for the Protection of Human Rights and Fundamental Freedoms. The recurrence of the breaches identified bears ample evidence of their prevalence».

The document addresses the prosecutor's office in its entirety as the authority given the power of oversight over legality, so it has a bone to pick with the investigative authorities, the police and the national courts alike. Thus, with reference to the European Court's position that the burden of the consequences of irregularities in pre-trial investigation may not be placed on the applicant, the Circular says:

"The errors and oversights of public authorities may not aggravate the accused's situation. In other words, the risk of any error made by the prosecution authorities or the court itself must be borne by the state, and these errors may not be corrected at the expense of the accused».

For its part, the European Court recognised in its judgment of 26 May 2009 in the case of Batsanina $v$. Russia that in certain circumstances (protection of interests of the most vulnerable social groups, cases of great public import etc.) the involvement of compliance monitoring authorities as a party to a civil process may be justified and is not in contravention of the principle of equality of arms ${ }^{524}$. The European Court formulated its position with a reference to Finding No 3 (2008), made by the Consultative Council of European Prosecutors General at the conference in St. Petersburg on such a sensitive issue as prevention of

Human Rights and Fundamental Freedoms»;

- Circular of 15 September 2010, "On violation of the rights of Russian citizens due to the use of violence at the pre-trial stage of criminal process, as established by decisions of the European Court of Human Rights»;

- Circular of S.G Kekhlerov, a Deputy Prosecutor General of the Russian Federation, of 21 December 2010, "On certain judgments of the European Court of Human Rights».

522 Предотвратить произвол и злоупотребление со стороны полиции: требование постановлений Европейского Суда по правам человека по России. Предварительный доклад, подготовленный Департаментом по исполнению постановлений Европейского Суда, Совет Европы [Put a stop to police abuse and brutality: the message of judgments of the European Court of Human Rights for Russia. Information document prepared by the Department for the Execution of Judgments of the European Court of Human Rights, Council of Europe]. Strasbourg, 13 October 2010 (in Russian) // DGHL-Exec/INF (2010)2.

${ }^{523}$ Full version is available on the official website of the Prosecutor General of the Russian Federation at http://www.genproc. gov.ru/documents/espch/document-130. A Russian-language version is published in the Права человека. Практика Европейского Суда по правам человека [Human Rights. Case-Law of the European Court of Human Rights] journal, 2011, No 2.

${ }^{524}$ For the [Russian-language] text of the judgment, see: Human Rights. Case-Law of the European Court of Human Rights, 2009, No 9. 
«improper influence on the process of adjudication» (see section 17 of the judgment), having found that

"the principle of equality of arms was complied with in this trial, as is required for ensuring a fair balance between the interests of the parties to the case» ( $§ 27$ of the judgment)».

\section{Acts of the Ministry of Justice of the Russian Federation}

Even before the apparatus of the Representative of the Russian Federation at the European Court of Human Rights was placed under the jurisdiction of the Ministry of Justice (March 2007), the Ministry seemed to be closely monitoring the European Court judgments within its remit, particularly after 1 August 1998, when the Federal Correctional Service became affiliated with the Ministry of Justice (for your information, following the Russian Federation President's Resolution of 12 July 2005, No 796 «On additional safeguards for the rights, freedoms and legitimate interests of persons suspected and accused of crimes", which, "taking into account the recommendations» of the Parliamentary Assembly of the Council of Europe, integrated the pre-trial detention centres offices of the offices of the Federal Security Service of Russia into the correctional system). For example, it was largely thanks to the efforts of the then chief of the Federal Correctional Service Yu.I. Kalinin (who personally attended the hearings in Strasbourg in the case of Kalashnikov v. Russia) that the Ministry of Justice in its Resolution of 3 November 2005, No 205, amended the "Prison Rules of Conduct» as regards the arrangements for inmates' correspondence. Specifically, it limited the censorship of inmates' incoming and outgoing correspondence:

"The inmate's correspondence with the court, Prosecutor's office, superior authority in the correctional system, as well as the Human Rights Commissioner in the Russian Federation, the human rights commissioners in the Russian Federation regions, a non-governmental watchdog commission set up in accordance with the legislation of the Russian Federation, and the European Court of Human Rights shall be exempt from censorship».

It would be logical to mention the Ministry of Justice's reinstatement of the registration of the Republican Party of Russia following the European Court judgment of 12 April 2011 in the case of Republican Party v. Russia, although I doubt whether it can be counted as an "achievement» when such a cornerstone institution in a rule-of-law state shows itself a legal realist and does its job...

On the other end of the spectrum, the performance of the Representative at the European Court for the execution of the European Court's notable judgments concerning Russia deserves a high rating, despite sneers from certain commentators. This relates first of all, to the execution of the "pilot judgment» in the case of Burdov v. Russia (2), where the European Court - based on nearly two hundred judgments in similar situations - held that lack of a proper mechanism to monitor compliance with the decisions handed down by domestic courts and of an effective remedy against the pernicious practice of non-compliance with court rulings is a systemic (structural) fault of the Russian legal system - and ordered the respondent government to introduce appropriate changes to the legislation. The law of 30 April 2010 was enacted one year later on damages for procedural delays ${ }^{525}$.

Not only did the Ministry of Justice lobby hard for a speedy enactment of this law, having given a leg-up to the originator of the bill, the Supreme Court of the Russian Federation, but it also in compliance with the judgment in the case of Burdov v. Russia (2) and off its own bat entered into hundreds of friendly settlements in the cases in this series that had been appealed to Strasbourg, in so doing speeding up the resolution of conflicts on the domestic level. Note that and courts of general jurisdiction, too, guided by the law of 30 April 2010 and amended Article 392 of the Code of Civil Procedure (review of cases upon newly discovered evidence, which

525 Federal Law of the Russian Federation of 30 April 2010, No 68-FZ, "On damages for violation of the right to a trial within a reasonable time or of the right to execution of a court ruling within a reasonable time». 
were finally made to include European Court judgments in a specific case), became actively involved in the review of private claims for failure to execute court rulings rendered in their favour. As a result, the share of "Burdov series» applications to the European Court dropped from $40 \%$ to $7 \%$ and centres for the most part on the so-called non-monetary obligations of the government. The European Court, incidentally, has geared up to address this problem too. For example, in its judgments in the cases of llyushkin and Others v. Russia (17 April 2012), and Kalinkin and Others v. Russia (17 April 2012, became final 24 September 2012), the European Court found a violation of Article 13 of the Convention on account of Russia still lacking an effective remedy against infringement of the right to execution within a reasonable time of court rulings imposing obligations «in kind». It also communicated to the authorities of the Russian Federation the application in the case of Gerasimov and 14 others v. Russia, having notified them that it may use a new pilot procedure, this time for failure to enforce nonmonetary awards. In response, the Ministry of Justice called for a speedy drafting of a federal law to amend the legislation in keeping with this position of the European Court, which found that the law of 30 April 2010 had failed to remedy all the shortcomings in the enforcement of court rulings.

Finally, last but not least, it is the Ministry of Justice that pursuant to the Russian Federation President's Resolution of 20 May 2011, "On monitoring law enforcement in the Russian Federation", has been tasked with annual monitoring of law-application process in the Russian Federation for the purposes of execution of the judgments of the Constitutional Court of the Russian Federation and the European Court of Human Rights that necessitate the adoption (promulgation), amendment or revocation (repeal) of legislative and other legal acts of the Russian Federation.

As early as in its first progress report on the monitoring of law-application process in the Russian Federation for 2011, the Ministry of Justice published a List of Judgments of the European Court of Human Rights that necessitate the amendment of the legislation of the Russian Federation. Featured prominently on the List are items on the execution of the pilot judgments both in the case of Burdov v. Russia (2) (discussed above) and in the case of Ananyev and others v. Russia (applications No 42525/07 and 60800/08; judgment of 10 January 2012), where the European Court found a structural problem related to the inadequate conditions of pre-trial detention and lack of effective remedies against the breaches involved. A kind of roadmap has been developed, as approved by the Committee of Ministers of the Council of Europe in October 2012, for a package of measures aimed at improving the legislation and law-application practices for the purposes of complying with that judgment. Time will tell how effective these measures are. But the speed of response to the European Court judgment is a litmus test in and of itself.

The last thing one wants to do on the occasion of the anniversary is to paint a rosy picture of Russia's implementation of the European Convention for the Protection of Human Rights and Fundamental Freedoms, not only because of the hype surrounding certain high-profile cases and the latest «initiatives» of the legislator, but also because there are unfortunately still systemic (structural) problems addressed by the European Court in its early judgments in 2002-2006. I recall that as far back as in June 2006, when Russia chaired the Committee of Ministers of the Council of Europe, during an international conference in Yaroslavl, I named those problems ${ }^{526}$. Alas, at year-end 2012, I was forced once again to point out the fact that those problems had not "gone away», but came under closer scrutiny from the European Court ${ }^{527}$. I will name these problems once more:

526 Ковлер А.И. Новые тенденции в практике Европейского Суда по правам человека: «пилотные постановления» о «структурных проблемах» [Kovler A.I. New trends in the case-law of the European Court of Human Rights: "pilot judgments» on «structural problems»] // Human Rights. Case-Law of the European Court of Human Rights, 2006, No 5. 
- inefficiency of investigation into the disappearances in the North Caucasus (Article 2 of the Convention in its procedural aspect);

- inefficiency of investigation into the abuses during arrests, inquires, and investigative actions (Article 3 of the Convention in its procedural aspect);

- quality of medical assistance to inmates (Article 3 of the Convention in its substantive aspect);

- on-going wide use of arrest and detention, not infrequently in administrative cases; procedural irregularities during review of motions for change of restrictive measure, long periods of detention (Article 5 of the Convention);

- failure to enforce court judgments on the public authorities' obligations «in kind» (Article 6 of the Convention);

- stalled reform of the review procedure in civil proceedings (Article 6 of the Convention);

- long prison sentences for drug trafficking based solely on the evidence produced through entrapment by agent-provocateur; arbitrary interpretation of the statutory provisions on operational-search activities (Article 6 of the Convention and specifically paragraph 2 - presumption of innocence);

- problems with ensuring equality of arms in civil and criminal procedure (summons of the parties to a court hearing, commissioning of expert evidence, examination of witnesses for the defence, right to effective defence).

No doubt, attempts to solve these problems by legislative amendments and interpretation of the European standards by supreme courts, the Prosecutor's office and justice agencies make a strong contribution to the implementation of the Convention's standards at the national level. It was the purpose of this publication to «take stock» of such means, which were not part of Russia's legal system 15-20 years ago. But, alas, law-application practices are lagging far behind the proposed methodologies. Moreover, to describe the general legal culture and, if you want, professional instincts of the bulk of the law-application officials, you need the talent of Mikhail A. Bulgakov ${ }^{528}$. But this is no topic fit for an "anniversary» ${ }^{529}$.

Given the rising number of filings in Strasbourg under Articles 8-11 of the Convention, it is feared that the legislator's initiatives of 2012-2013, designed as they are to impose a certain pattern on the activities of not-for-profit organizations and a harsher punishment for «hurting the feelings» of religious believers or for "propaganda» of unconventional sexual orientation, can give rise to such a surge in these complaints that it will justify talking about new «systemic» problems.

One is reluctant to scrape the bottom to come up with an upbeat conclusion but there is no cause for an apocalyptic vision either. The Russian-European dialogue on human rights is well

527 Kovler A.І., Россия в Европейском Суде: 2012-й год - год «большого перелома» [Russia at the European Court: 2012, a watershed year] // Rossiskoye Pravosudiye [Russian Justice], 2013, No 3.

528 Mikhail Afanasyevich Bulgakov was a Soviet Russian writer and playwright active in the first half of the 20th century.

529 The problem of efficient implementation of the Convention is addressed in a highly critical manner towards the law-enforcement system in hundreds of publications, including those of the author. See also recent works: Burkov A.L. Конвенция о защите прав человека в судах России [The Convention on Human Rights in Russian courts]. М., 2010; Trubnikova T.V., Право на справедливое судебное разбирательство: правовые позиции Европейского Суда по правам человека и их реализация в уголовном процессе Российской Федерации [Right to a fair trial: legal positions of the European Court of Human Rights and their integration into the criminal procedure of the Russian Federation]. Tomsk, 2011; Sultanov A.R., Европейские правовые стандарты, уроки истории и правоприменительная практика [European legal standards, history lessons and law-application practices]. М., 2012. 
underway; it is not unlike a tug of war, but its results (albeit modest) are evident. My generation, which is possibly the last one to have been raised on the classics, unconsciously brings to mind salutary images from high literature. So, I want to close with the words of a Chekhov protagonist: “Дело надо делать господа, дело...” («Кеep at it, gentlemen, keep at it...»).

Translation into English

(C) «Human Rights. Case-Law of the European Court of Human Rights» Journal 


\title{
THE REPUBLIC OF SERBIA
}

\author{
Dragoljub Popović* and Tanasije Marinković*
}

\section{INTRODUCTION}

Serbia entered the European system of human rights protection in 2004, as the $45^{\text {th }}$ Member-State of the Council of Europe. Like many other post-communist countries of the Central and Eastern Europe, Serbia lacked its own rule of law tradition, which nevertheless enabled it to equate quite easily the human rights protection with the Convention system. ${ }^{530}$

In 2006 Serbia adopted a new Constitution which provided, inter alia, for the direct application of human rights, guaranteed by the Constitution and ratified international treaties, as well as for the interpretation of those provisions in accordance with the practice of international institutions which supervise the implementation of the given international law standards. An extensive reform of the legal system also took place in order to accommodate for the proper subsidiary implementation of the European Convention on Human Rights (hereinafter: the Convention), as well as for the ex-post mechanisms of fulfilling its obligations flowing from violations found by the European Court of Human Rights (hereinafter: the Court). ${ }^{531}$

However, a lack of proper legal and political culture was not without its negative consequences, manifesting itself primarily in a generally inefficient judiciary, and in a misunderstanding, to a certain extent, of some of the fundamental concepts of the Convention system. In that sense, the contrast between the "law in books" and "law in action" is striking, as exemplified by the fact that in 2012 Serbia ranked as the fifth on the Court's list of countries with the greatest number of applications filed against it, and it ruled supreme on it when examined per capita. ${ }^{532}$ This trend can certainly be attributed to the poor knowledge about the Convention and its case-law in general, and even more importantly to the absence of an adequate university education on the European Human Rights Law for the to be judges, prosecutors and attorneys.

Despite discouraging statistics and the absence of a systematic legal training in the field, references to the Court's jurisprudence are more and more frequent in the case-law of ordinary courts in Serbia, providing evidence of the shift in the legal practice towards adoption of the European values and standards, as embodied in the Convention. Particularly important, in that respect, is the Constitutional Court's reliance on the Convention case-law, and the attribution to it of both binding and persuasive force, in various proceedings before it. More generally, these affirmations undoubtedly witness the evolution of understanding of law and of its sources (especially of the

\footnotetext{
530 It was observed among scholars that in the late-ratifying States, including those from Central and Eastern Europe, the political legitimacy of the Convention and the Court was largely taken for granted. Being in the throes of democratization, following long years under authoritarian rule, they strongly equated democracy and rights protection. The Convention offered them "an established, 'external' and therefore legitimate, normative standard for the transition to constitutional democracy". Helen Keller and Alec Stone Sweet, "Assessing the Impact of the ECHR on National Legal Systems', in Keller and Stone Sweet (eds.), A Europe of Rights - The Impact of the ECHR on National Legal Systems (Oxford: Oxford University Press, 2008), p. 679.

${ }^{531}$ For instance, Serbia introduced the constitutional complaint and a possibility for re-opening of domestic proceedings, in comparison to France, one of the original Contracting Parties, in which the Constitution was only recently amended to provide for the question prioritaire de la constitutionalité, and in which it has long been considered that paying damages established by the Court is the only formal obligation flowing from a finding of violation, i.e. that judgments of the Court do not call into question the legality of judicial proceedings. Elisabeth Lambert Abdelgawad and Anne Weber, 'The Reception Process in France and Germany', in Keller and Stone Sweet (eds.), A Europe of Rights, p. 126.

532 Human Rights in Serbia 2012 (Belgrade: The Belgrade Centre for Human Rights, 2013), p. 28.
} 
importance of the "judge made law"), as well as of the role of the State and of its sovereign prerogatives.

\section{IMPORTANT ASPECTS OF THE ACCESSION OF SERBIA TO THE CONVENTION}

\subsection{Brief Overview of the Constitutional Order}

The Republic of Serbia is a constitutional democracy, with a parliamentary government, and a decentralized territorial organization. The present Constitution of Serbia was proclaimed on 8 November 2006, replacing the 1990 Constitution. In the 2006 Constitution Serbia is defined as "a state of the Serbian people and of all citizens who live in it, founded on the rule of law and social justice, principles of civil democracy, human and minority rights and freedoms, and commitment to the European principles and values". ${ }^{533}$ Following this system of values, the Constitution provides for a charter of rights and liberties. Those provisions are "in line with the European standards and go in some respect even beyond that". ${ }^{534}$

The horizontal organization of power is based on the separation of powers principle. ${ }^{535}$ The National Assembly is the highest representative body, vested with constitution making and legislative powers. ${ }^{536}$ The President of the Republic expresses the state unity of Serbia, and is elected by direct suffrage, but has limited competence. ${ }^{537}$ The Government - the holder of the executive power - is elected by the National Assembly and is accountable to it. ${ }^{538}$ The elements of the parliamentary system are completed by the power of the President to dissolve the National Assembly, upon the reasoned proposal of the Government. ${ }^{539}$

The Constitution proclaims the independence of the judicial power, providing for its substantive and personal guaranties. ${ }^{540}$ In addition to this, it introduces the Supreme Judicial Council, to secure the independence and autonomy of the courts and judges. ${ }^{541}$ The judiciary is three-tiered, with the Supreme Court of Cassation at its apex. ${ }^{542}$ The ordinary courts - first instance and high courts, and appellate courts, as the second instance courts - are established by the legislation, ${ }^{543}$ as well as the specialized courts: commercial courts and Commercial Court of Appeal, magistrate courts and Magistrate High Court, and the Administrative Court. ${ }^{544}$

The Constitutional Court is established by the Constitution, with the status and jurisdiction, which are typical for centralized, European model of constitutional adjudication. Hence, it is an autonomous and independent state institution, which protects the principles of constitutionality and

\footnotetext{
${ }^{533}$ Constitution of the Republic of Serbia, Official Herald of the Republic of Serbia, no. 98/2006, Article 1.

534 Opinion on the Constitution of Serbia, European Commission for Democracy through Law, Strasbourg, 19 March 2007, p. 7. This opinion of the Venice Commission is generally shared by the Serbian legal doctrine. Cf. Ivana Krstic, 'Human Rights Protection in Serbia from a Constitutional Standpoint', in Tackling Constitutional Challenges on the Road to the European Union: Perspectives from South-East European Accession Countries (Skopje: Association Zenith, Konrad Adenauer Stiftung, 2012), p. 111; Dejan Pavlovic, 'Serbia', in Leonard Hammer and Frank Emmert (eds.), The European Convention on Human Rights and Fundamental Freedoms in Central and Eastern Europe (The Hague: Eleven International Publishing, 2012), p. 482.

535 Constitution, Article 4 (2).

536 Ibid., Article 98.

537 See the Constitution, Articles 111-114.

538 See the Constitution, Articles 122-124 and 127-130.

539 Ibid., Article 109 (1).

540 Ibid., Article 145-152.

541 Ibid., Article 153-154.

542 Ibid., Article 143 (4).

543 Organization of Courts Act, Official Herald of the Republic of Serbia, no. 116/2008, 104/2009, 101/2010, and 101/2011, Articles 22-24.

544 Ibid., Article 11 (4).
} 
legality, as well as human and minority rights and freedoms. ${ }^{545}$ Its rulings are final, enforceable and binding. ${ }^{546}$ It has a wide range of competence, including the abstract review of constitutionality and of conformity with the ratified international treaties. ${ }^{547}$ Nevertheless, a real breakthrough of the constitutional justice in Serbia has been the practice of the individual constitutional complaint, introduced for the first time by the 2006 Constitution. Any individual alleging a violation or denial of constitutional rights and freedoms by state institutions or other public authorities can lodge a constitutional complaint with the Court, if other legal remedies are not specified or have already been exhausted. ${ }^{548}$ Among other powers, the Court is entitled to decide on a ban of a political party, trade union organization or civic association, as well as upon a complaint lodged by a judge against the termination of its tenure of office..$^{549}$

The Constitution provides also for the Civic Defender, another independent state institution, entrusted with the protection of citizens' rights and monitoring of the work of public administration. ${ }^{550}$ The legislation introduces specialized ombudspersons: Commissioner for Information of Public Importance and Personal Data Protection, and 'Commissioner for the Protection of Equality. ${ }^{551}$

\subsection{Status of the Convention in the Domestic Legal Order}

The Convention was ratified on 26 December 2003 by the then State Union of Serbia and Montenegro. ${ }^{552}$ The State Union was bound by the Convention and its protocols as of 3 March 2004 when the instrument of ratification was deposited with the Secretary General of the Council of Europe. With the dissolution of the Union, Serbia became its sole successor, and the Committee of Ministers adopted in 2006 a declaration on the continuation of Serbia's membership in the Council of Europe. ${ }^{553}$

Like all ratified and published international treaties, the Convention is automatically integrated into the Serbian legal order. ${ }^{554}$ According to the 2006 Constitution, the Convention is superior to national law but not to the Constitution itself. ${ }^{555}$ Yet a lower hierarchical rank with regard to the Constitution has been mitigated by the constitutional provisions allowing the direct applicability of the Convention and stipulating that the Convention, together with the Court's case law, serve as an

\footnotetext{
545 Constitution, Article 166.

546 Ibid. See also Article 171.

547 Ibid., Article 167.

548 Ibid., Article 170.
}

549 Constitution, Article 148 (1) and (2), provides that the judge's tenure of office shall terminate at his/her own request, upon coming into force of legally prescribed conditions or upon relief of duty for reasons stipulated by law, as well as if he/she is not appointed to the position of a permanent judge; the High Council of Judiciary passes a decision on termination of a judge's tenure of office against which a judge may lodge a complaint with the Constitutional Court.

550 Constitution, Article 138.

${ }^{551}$ Free Access to Information of Public Importance Act, Official Herald of the Republic of Serbia, no. 120/2004; Personal Data Protection Act, Official Herald of the Republic of Serbia, no. 97/2008; Prohibition of Discrimination Act, Official Herald of the Republic of Serbia, no. 22/2009.

552 Official Journal of Serbia and Montenegro - International Treaties, no. 9/2003 and 5/2005.

553 See the Declaration by the Committee of Ministers of the Council of Europe on Continuation by the Republic of Serbia of Membership of the State Union of Serbia and Montenegro, Decl-14.06.2006/1E /14 June 2006,

https://wcd.coe.int/wcd/ViewDoc.jsp?id=1013255\&Site=CM\&BackColorInternet=C3C3C3\&BackColorlntranet= EDB021\&BackColorLogged=F5D383, (last visited 25 September 2013).

554 Articles 16 (2) and 194 (4) of the Constitution provide that "ratified international treaties and generally accepted rules of international law shall be part of the legal system of the Republic of Serbia."

555 According to Articles 16 (2) and 194 (5) the Constitution has supremacy over ratified international treaties. However, Article 194 (6) stipulates that ratified international treaties and generally accepted rules of the international law have supremacy over laws and decrees enacted in the Republic of Serbia. 
interpretative tool of the constitutional provisions on human and minority rights. Namely, according to Article 16 (2) of the Constitution, ratified international treaties and generally accepted rules of international law are directly applicable, while Article 20 (3) specifies that constitutional provisions on human and minority rights are to be interpreted to the benefit of promoting values of a democratic society, pursuant to valid international standards in human and minority rights, as well as the practice of international institutions which supervise their implementation. ${ }^{556}$ Finally, of equal importance here is the opinion of the Constitutional Court regarding the availability of the national remedy to protect human rights guaranteed in the international treaties: the rights incorporated in the constitutional system by the ratified international treaties have the same rank as rights guaranteed by the Constitution and their protection can be the subject of constitutional complaint filed with the Constitutional Court. ${ }^{557}$

In sum, the Convention has been accorded a supra-legislative status and is directly enforceable, which makes possible for the Serbian judges to give precedence to it over domestic legislation.

\subsection{Mechanism of Implementation and Coordination}

In the parliamentary system of government, as it is the case in Serbia, legislation is generally proposed by the Government, under the initiative of its ministers. ${ }^{558}$ In exercising this function, the Government is assisted by its own special service, the Secretariat for Legislation, which sees that the laws and decrees in the legal system are synchronized and that they satisfy necessary technical qualities. ${ }^{559}$ When it comes to the implementation of the Convention law, the Ministry of Justice and State Administration represents Republic of Serbia before the Court, it sees that the judgments of that Court, delivered in respect of Serbia, are published, it and supervises their execution. 560 Furthermore, the Government established a special body, named the European Court of Human Rights Liaison Committee, with the task to enhance and supervise the implementation of the Convention. ${ }^{561}$ In particular, the Committee adopts recommendations and opinions, related to the action of state institutions, with the view to lower the number of applications filed against Serbia. ${ }^{562}$ Although, these mechanisms certainly allow for the implementation of the Convention law at the national level (in the law-making process), they could be improved as well. For instance, the legislation in force provides for a much more stringent harmonization of the domestic law with the European Union (hereinafter: the EU) norms, in spite of the fact that Serbia is still not a member of this organization. ${ }^{563}$ Thus, the ministries are generally under the obligation to secure, within their respective competence, the accommodation of the national legislation with the EU law, and for some of the ministries (e.g. Ministry of Trade and Telecommunications) this is stipulated as their explicit responsibility. ${ }^{564}$

The same remark is equally valid for the legislative process in the National Assembly. While, the Standing Orders prescribe that each and every bill has to be accompanied by a statement on its

\footnotetext{
556 Unsurprisingly, the Venice Commission welcomed this reference, recognizing in it the binding and persuasive force of the Convention case-law. Opinion on the Constitution of Serbia, Ibid., p. 8.

557 See Opinions of the Constitutional Court regarding Proceedings on Consideration and Adjudicating on Constitutional Complaint, the Constitutional Court, no. 1-8/11/09, 2 April 2009, http://www.ustavni.sud.rs/page/view/163-100890/stavovi-suda, (last visited 25 September 2013).

558 Constitution, Article 123 (1 (4)), and the Government Act, Official Herald of the Republic of Serbia, nos. 55/2005, 71/2005, 101/2007, 65/2008, 16/2011, 68/2012 and 72/2012, Article 14 (1).

559 Ministries Act, Official Herald of the Republic of Serbia, no. 72/2012, Article 24 (1)

560 Ibid., Article 10 (1).

${ }^{561}$ Decree on the Establishment of the European Court of Human Rights Liaison Committee, Official Herald of the Republic of Serbia, no. 35/2013, Article 2 (2).

562 Ibid.

563 Serbia was granted the EU candidate status on $1^{\text {st }}$ March 2012.

564 Ministries Act, Articles 19 (2) and 20
} 
accordance with the EU law, ${ }^{565}$ there is no such requirement in respect of the Convention case-law. Nevertheless, the Committee on European Integrations, which is a parliamentary working body, regularly examines the bills from the perspective of their conformity not only with the EU legislation, but also with the Council of Europe rules. ${ }^{566}$

As to the execution of the Court's judgments rendered against Serbia, the Ministry of Justice is charged to supervise it, and the European Court of Human Rights Liaison Committee is entitled not only to supervise their execution, in accordance with the Article 46 of the Convention, but also to adopt recommendations and opinions in that respect. ${ }^{567}$

The implementation of the Convention case-law by the judiciary can be analyzed in two different contexts. One is the direct application of the Convention law in accordance with Article 18 of the Constitution. 568 The other context is individual, and concerns the reopening of the domestic proceedings, at the initiative of the applicant who was successful in claiming the violation of its Convention rights before the Court. ${ }^{569}$

\section{COURT'S CASE-LAW IN RELATION TO SERBIA}

By the end of June 2013 the Court delivered 79 judgments against Serbia, finding in almost ninety percent of them a violation of at least one of Convention rights. ${ }^{570}$ More than two thirds of these cases concerned the violation of Article 6 (1) of the Convention (primarily the "reasonable time" requirement, but also other aspects of the right to a fair trial), independently or in conjunction with other Convention articles $(3,5,8,13$, Protocol 1 Article 1). The Court also found independent violations of articles 2, 3, 5 (3), 6 (2), 8, 10, 14 and of Protocol 1 Article 1. European Court's case-law in relation to Serbia will be examined through the examples of the cases concerning (predominantly) socially owned companies (3.1), harmonizing of jurisprudence (3.2) and unacceptable restrictions on the freedom of speech (3.3), which indicate some of the systemic problems in the Serbian legal system. ${ }^{571}$

\subsection{Cases Concerning (Predominantly) Socially Owned Companies}

A great deal of applications in respect of which the Court found that Serbia infringed the Convention concern non-enforcement of judgments rendered against companies (predominantly) comprised of socially-owned capital. Socially-owned companies (SOC) are a relic of "self-management", the former Yugoslav brand of communism. Although they are independent legal entities which are both

565 Standing Orders of the National Assembly, Official Herald of the Republic of Serbia, no. 20/2012 (consolidated version), Article 151 (4).

566 Ibid., Article 64 (1)

567 Decree on the Establishment of the European Court of Human Rights Liaison Committee, Article 2 (2).

568 A further support for the overall reception of the Convention case-law by the judiciary is provided by Article 6 (3) of the Judges Act, Official Herald of the Republic of Serbia, no. 116/2008, 58/2009, 104/2009, $101 / 2010,8 / 2012$ and 121/2012, which stipulates that when the Court's judgment "establishes that human rights and fundamental freedoms were violated in the course of a judicial proceeding and that judgment was based on that violation, or that judgment was not rendered because of the violation of the right to a trial within a reasonable time, the Republic of Serbia may demand that the judge remunerates the awarded compensation, if the violation was caused willfully or by gross negligence".

569 For more information on the reopening of the judicial proceedings see section 5., infra.

570 Out of these 79 judgments, two are currently being reexamined before the Grand Chamber: Vučković and Others v. Serbia, nos. 17153/11 et seq., 28 August 2012, and Ališić and Others v. Bosnia and Herzegovina, Croatia, Serbia, Slovenia and The Former Yugoslav Republic of Macedonia, nos. 60642/08 et seq., 6 November 2012.

${ }^{571}$ For a somewhat broader selection of case-law in respect of Serbia, see: Vladan Joksimović, 'Srbija pred Evropskim sudom za ljudska prava', (2011) 3 Sveske za javno pravo 26-33 <= 'Serbia before the European Court of Human Rights', (2011) 3 Blätter für Offentliches Rechts 26-33>. 
owned and run by their own employees and can be subjected to regular insolvency proceedings, the legislation in force provided that they were to be privatised by March 2007, and the funds thus obtained were to be paid into the State's budget.

SOC are those companies which are entirely comprised of social capital. Companies whose capital is predominantly socially-owned, but which are not formally being privatised, cannot, without prior approval by the Privatisation Agency, itself a State body, adopt their own decisions concerning their: capital, reorganisation, restructuring and investment, the partial sale or mortgage of their assets, the settlement of their outstanding claims and the taking or giving of loans and guarantees outside the scope of their "regular business operations". Also, no decisions concerning the status and organisation of such companies can be adopted without the Government's prior approval. ${ }^{572}$

Referring to the given institutional and operational dependence of the (predominantly) socially owned companies from the State, the Court found in R. Kačapor and Others v. Serbia that the State should be held liable not only for the non-enforcement of judgments which had been rendered against companies (predominantly) comprised of socially-owned capital, under article 6 (1) of the Convention, but also for the outstanding obligations of these debtors, under Article 1, Protocol 1 of the Convention. As a result, the Court awards non-pecuniary damages for the failure of State to enforce its final judgements, and at the same time it orders the State to pay from its own funds the sums awarded to the applicants by the given judgments. ${ }^{573}$ The initial reluctance of the Constitutional Court to abide by the Court's precedent by awarding both pecuniary and nonpecuniary damages led to the disqualification of the constitutional complaint as an effective legal remedy in this type of cases. ${ }^{574}$

\subsection{Harmonising Jurisprudence}

A problem concerning the harmonization of jurisprudence in Serbia deserves a special attention, because it gives rise to a certain amount of applications to the Court. It consists in the lack of proper harmonising mechanisms, or in the absence of the intention to use the existing ones or to develop those by way of interpretation. The cases against Serbia concerning divergent jurisprudence emerged in the Strasbourg case-law before the reform of the judiciary. The leading case was Vinčić and Others v. Serbia. ${ }^{575}$ It was followed by the cases of Rakić and Živić. ${ }^{576}$ The problem has not been resolved so far at the domestic level and new applications threaten the Court. ${ }^{577}$ The reform of the judiciary in Serbia should be completed in this respect and it is noteworthy that its completion may not require legislation amendments, but only the alteration of the domestic courts' practices under the existing one.

\footnotetext{
572 For more information on the relevant Serbian legislation in respect of (predominantly) socially owned companies, see: $R$. Kačapor and Others v. Serbia, nos. 2269/06 et seq., 15 January 2008, par. 71-76.

${ }^{573}$ R. Kačapor and Others v. Serbia, Ibid., par. 123-129; Crnišanin and Others v. Serbia, nos. 35835/05 et seq., 13 January 2009, par. 137-139 and 143-145; Grišević and Others v. Serbia, nos. 16909/06, 38989/06 and 39235/06, 21 July 2009, par. 74-79; Rašković and Milunović v. Serbia, nos. 1789/07 and 28058/07, 31 May 2011, par. 81-86.

${ }^{574}$ For more information on the dialogue between the Court and the Constitutional Court in this type of cases, see: Ciril Ribičič, Bosa Nenadić and Tanasije Marinković, 'Multilevel System of Human Rights Protection in Europe - A View from the Central and Eastern Europe', in Lidija R. Basta Fleiner, Tanasije Marinković (eds.), Key Development in Constitutionalism and Constitutional Law - On the Occasion of the $30^{\text {th }}$ Anniversary of the IACL (Utrecht: Eleven International Publishing, 2014).

575 Vinčić and Others v. Serbia, no. 44698 et seq., 1December 2009.

576 Rakić and Others v. Serbia, no. 47460/07 et seq., 5 October 2010; and Živić v. Serbia, no. 37024/08, 23 August 2011.

577 For brief comments on the issue cf. Dragoljub Popović, 'Uticaj Evropske konvencije za zaštitu ljudskih prava i osnovnih sloboda na srpsko pravo', (2012) 1 Bilten sudske prakse - Vrhovni kasacioni sud <= 'The Impact of the European Convention on Human Rights on the Serbian Law', (2012) 1 Supreme Court of Cassation Bulletin>.
} 


\subsection{Unacceptable Restrictions on the Freedom of Speech}

The Court's case-law in the field of freedom of speech disclosed at first a lack of understanding of the nature of public (political) speech, on the side of the Serbian judiciary. In four judgments concerning the freedom of speech, the Court found that there was no pressing social need for the interference with that freedom and that it therefore was disproportionate. ${ }^{578}$ In Lepojić v. Serbia and Filipović $v$. Serbia, the applicants were local politicians who had been criminally convicted for criticising the mayors of their municipalities. In Bodrožić v. Serbia and Bodrožić and Vujin v. Serbia the applications were filed by journalists who had also been sentenced for having used various expressions in respect of public figures. Those were a historian, who had made political statements publicly, in the former, and an attorney, who had become a well-known figure on a local scale by representing the management of a factory in a high-profile insolvency case, in the latter case.

The Court noted in Lepojic that the "applicant's article contained some strong language" the veracity of which he was unable to prove before the domestic courts". ${ }^{579}$ The Mayor in Filipović "had been publicly accused... of criminal 'embezzlement' in the absence of a conviction to that effect". ${ }^{580}$ In Bodrožić the applicant's conviction was based on the expressions used to describe the given public figure as "an idiot", "a fascist" and "a member of the fascist movement". ${ }^{581}$ And in Bodrožić and Vujin, the texts in question "obviously contained a certain degree of mockery" 582 . However, the Court concluded that the discussions which gave rise to the cases were clearly of great public interest and the object of an ongoing political debate. ${ }^{583}$ It also established that the given expressions were not deprived of factual basis. ${ }^{584}$ Finally, the Court found in all four cases that the convictions to which the applicants were subjected were disproportionate, as the fines imposed on them could, in case of default, be replaced by a prison term, while the compensations amounted to several average monthly salaries in Serbia at the relevant time. ${ }^{585}$

\section{THE COURT'S CASE-LAW'S EFFECTS AT THE NATIONAL LEVEL}

\subsection{Referring to the Court's Case-Law}

The attitude towards the Convention and the Court's jurisprudence has led to alteration of the domestic courts' practices, as well as to the pleading of the parties. The domestic courts of various levels make references in their judgments to the Convention law and so do the representatives of the parties in their pleadings. This issue is not merely technical. It shows the fundamental change in the domestic legal order, which, after the ratification of the Convention and the adoption of the 2006 Constitution, includes provisions of international law within itself. One of the authors of this text published in Serbian a brief analysis of a limited number of first instance courts' and appellate courts' judgments in which references to the Strasbourg case-law occurred. ${ }^{586}$ It should be concluded on the grounds of the analysis mentioned that the references to the Strasbourg jurisprudence are sometimes insufficient, short and not properly following the line of the Court's

\footnotetext{
578 Lepojić v. Serbia, no. 13909/05, 6 November 2007; Filipović v. Serbia, no. 27935/05, 20 November 2007; Bodrožić v. Serbia, no. 32550/05, 23 June 2009; Bodrožić and Vujin v. Serbia, no. 38435/05, 23 June 2009.

579 Lepojić v. Serbia, par. 77.

580 Filipović v. Serbia, par. 58.

581 Bodrožić v. Serbia, par. 49.

582 Bodrožić and Vujin v. Serbia, par. 36.

583 Lepojić v. Serbia, par. 77; Filipović v. Serbia, par. 58; Bodrožić v. Serbia, par. 55; Bodrožić and Vujin v. Serbia, par. 32.

${ }^{584}$ Bodrožić v. Serbia, par. 57; Bodrožić and Vujin v. Serbia, par. 36.

585 Lepojić v. Serbia, par. 77; Filipović v. Serbia, par. 58; Bodrožić v. Serbia, par. 58; Bodrožić and Vujin v. Serbia, par. 40-41.

586 Dragoljub Popović, op. cit.
} 
case-law. Nevertheless, their presence in judgments is quite significant and it provides evidence of the shift in the legal practices in Serbia towards adoption of the European values and standards as embodied in the Convention.

\subsection{Influences on domestic Legislation}

Among other influences of the Convention on the domestic legislation in Serbia some deserve to be mentioned. The amendments of the Civil Procedure Act, adopted shortly after the ratification of the Convention, introduced a new ground for reopening of the proceedings. ${ }^{587}$ Article 422 of the Act stipulated that reopening of the proceedings should be granted if "after a final judgment of a domestic court the European Court of Human Rights rendered a judgment on either the same or a similar issue in a case against Serbia". It is noteworthy that the provision referred not only to an issue which had been entrenched by the Court in the proceedings concerning the same issue as it had been raised before a domestic court, but also to a similar one, which brought a certain amount of flexibility to its implementation.

Another impact of the Convention system of the protection of human rights concerns legislation on the reasonable time requirement in judiciary proceedings. The text of the 2006 Constitution basically reproduced in short Article 6 of the Convention. ${ }^{588}$ That was the constitutional provision, which provided the basis for introducing a new remedy at the domestic level. The remedy is designed to protect the right to a fair hearing by providing compensation to parties to the proceedings in case of transgressing the limits of reasonable time, insofar as judiciary proceedings before domestic courts are concerned. It was introduced by Article 82 (2) of the Constitutional Court Act. ${ }^{599}$ It consists of a constitutional complaint and the competent court is the Constitutional Court, which led to its overburdening with cases, for the remedy appears to be in frequent use by the parties. ${ }^{590}$ Serbia introduced this remedy following the Italian model, which turned out to be inefficient at its source..$^{591}$ It should be reflected upon and the legislation should probably be amended.

\section{REMEDIES}

The protection of the Convention, at the national level, falls within the ambit of the ordinary and specialized courts, given the Convention's supra-legislative status and its direct effect in the Serbian legal system. ${ }^{592}$ The Constitution stipulates that the courts are autonomous and independent in the exercise of their functions, and that they rule in accordance with the Constitution, legislative acts, generally accepted rules of international law and ratified international treaties. ${ }^{593}$ Moreover, human and minority rights, guaranteed by generally accepted rules of international law and ratified international treaties, are directly enforceable. ${ }^{594}$ Therefore, the Convention is directly applicable and can be invoked before, and enforced by, the Serbian judiciary.

In practice, the protection of Convention rights and freedoms is most commonly achieved through the abstract (general) and concrete (individual) review of constitutionality and conventionality by

\footnotetext{
587 Civil Proceedings Act of 22 November 2004, Official Herald of the Republic of Serbia, no. 125/2004.

588 Cf. Art. 32 of the Constitution to Art. 6 of the Convention.

589 Constitutional Court Act, Official Herald of the Republic of Serbia, no. 109/2007, 99/2011 and 18/2013.

590 There were 8000 constitutional complaints of this kind pending in 2010. Cf. Constitutional Court of Serbia, Annual Report, 2010.

591 Cf. Marco Fabri, 'The Italian Maze towards Trials within Reasonable Time', in The Right to Trial within Reasonable Time and Short-Term Reform of the European Court of Human Rights (Strasbourg: Council of Europe, 2009); cf. also in Serbian, Slavoljub Carić, Pravo na suđenje u razumnom roku (Beograd: Službeni glasnik, 2008) <= Slavoljub Carić, Right to a Trial within a Reasonable Time (Belgrade: Official Herald, 2008) >. 592 See section 2.2., supra.

593 Constitution, Article 142.

${ }^{594}$ Constitution, Article 18 (2).
} 
the Constitutional Court, as well as through the reopening of judicial proceedings before the ordinary courts. While the former is anterior to the intervention of the Strasbourg Court, and is intended to prevent it, the latter is subsequent to it, rectifying the established violations of the Convention.

In accordance with the European model of judicial review, the Constitutional Court rules on the conformity of laws and decrees with the Constitution, generally accepted rules of international law and ratified international treaties. ${ }^{595}$ And not only that this control includes the abstract review of conventionality, but also when it reviews the constitutionality of laws and decrees the Constitutional Court normally interprets the entrenched constitutional rights and freedoms with respect to the Convention case-law, pursuant to Article 18 (3) of the Constitution. ${ }^{596}$ The Constitutional Court reviews, in this spirit, the constitutionality and conventionality of individual acts through the procedure of ordinary constitutional complaints (upon the exhaustion of other legal remedies, or even before it, in case of length of proceedings). The same applies when it rules on special complaints lodged by the dismissed judges. ${ }^{597}$

The other type of remedies concerns the reopening of the domestic judicial proceedings, at the initiative of the applicant who was successful in claiming the violation of its Convention rights before the Court. Thus, the Criminal Procedure Code provides that the request for the protection of legality may be filed in case of violation of human rights established by a judgment of the Court; ${ }^{598}$ the Civil Procedure Act stipulates that the request for the reopening of proceedings may be filed if the Court established a violation of human rights, in respect of a party in a proceeding, which could have had consequences on the outcome of the case; ${ }^{599}$ and, so does, mutatis mutandis, the Administrative Disputes Act. ${ }^{600}$

\section{DISSEMINATION OF KNOWLEDGE}

\subsection{Teaching and Scholarship}

At the undergraduate level of legal studies in Serbia, the European Human Rights Law is not taught as a separate course. Its basics are taught as a part of the course on the International Public Law, or at best within the International Human Rights Law, as an optional course. Classes in public, civil and criminal law may address the effects of the Convention case-law on the Serbian law, if only in passing. However, the selected topics in the European Human Rights Law are studied at the Master's and Doctoral level, and the LLM and PhD thesis on it are occasionally written and defended. It follows that although there are individual professorial efforts to bring the Convention case-law closer to the students, its dissemination through teaching is unsystematic and insufficient.

Doctrinal scholarship on the European human rights law is generally underdeveloped. There are no specialized journals devoted to this branch of law, nor is there a systematic commenting of the Convention case-law, in general, or in relation to Serbia. Nevertheless, the entry of Serbia into the European system of human rights protection, almost a decade ago, did propel the academic interest

\footnotetext{
595 Constitution, Article 167 (1(1)).

596 For instance, see section 7.2.2. infra, as well as Tanasije Marinković, 'Fighting Political Corruption in the Serbian Constitutional System', (2012) 1/2 Corruzione contro Costituzione, Percorsi Costituzionali, Cedam 123141.

597 For the relevant legislation, see sections 2.1. and 4.2., supra, and for a selection of the Constitutional Court's case-law, see sections 7.3. and 7.4., infra.

${ }^{598}$ Criminal Procedure Code, Official Herald of the Republic of Serbia, no. 72/2011, 101/2011 and 121/2012, Article 485 (1).

${ }^{599}$ Civil Procedure Act, Official Herald of the Republic of Serbia, no. 72/2011, Article 426, point 11.

${ }^{600}$ Administrative Disputes Act, Official Herald of the Republic of Serbia, no. 111/2009, Article 56, point 7.
} 
for it, hence the appearance of textbooks and studies addressing the organization, procedure and case-law of the Court, as well as the specific mechanisms of its administration of justice. ${ }^{601}$

\subsection{Judiciary and Lawyering}

Neither the Human Rights Law in general, nor the European Human Rights Law, in particular, are included in the bar exam in Serbia, ${ }^{602}$ reflecting the disregard for the (European) Human Rights Law in the curricula of the undergraduate legal studies. This gap between the status of the Convention law in Serbia and expected knowledge of judges on it, ${ }^{603}$ on the one side, and the legal knowledge which they receive in universities on the other, is partially bridged by the establishment of the Judicial Academy. Its role is to contribute to the more professional, independent and efficient judiciary and prosecutor's office by providing for the initial and continuous education, inter alia in the Convention case-law, of the (to be) judges and deputy prosecutors. ${ }^{604}$

However, the Court judgments, rendered against Serbia, are translated and published in the Official Herald of the Republic of Serbia. As a result, the references to the Strasbourg jurisprudence are becoming more and more present in the case-law of the ordinary courts. ${ }^{605}$ And, they are particularly numerous and significant in the Constitutional Court's rulings. ${ }^{606}$

Another important source of dissemination of knowledge of the Convention case-law are the NGOs who had started translating the most important Court judgments in Serbian and training lawyers in European Human Rights Law well before Serbia became a party to the Convention. ${ }^{607}$ The NGOs play an important role also in bringing strategic human rights cases either before the Court or before the Constitutional Court, and issue reports on the conformity of the legislation and practice in Serbia with the Convention case-law.

\section{THE INFLUENCE OF THE CASE-LAW AND THE DEMOCRATIZATION PROCESS}

Taking into account the distinction between the law in books and law in action, the impact of the Convention on the democratic changes in Serbia should particularly be scrutinized through the caselaw of the Constitutional Court of Serbia. A survey of the Constitutional Court's jurisprudence shows

601 Milan Paunović, Slavoljub Carić, Evropski sud za ljudska prava - osnovna načela i tok postupka (Beograd: Pravni fakultet Univerziteta u Beogradu, Službeni glasnik, 2006) <= European Court of Human RightsPrinciples and and Procedure (Belgrade: Faculty of Law University of Belgrade, Official Herald, 2006)>; Vojin Dimitrijević, Dragoljub Popović, Tatjana Papić, Vesna Petrović, Međunarodno pravo ljudskih prava (Beograd: Beogradski centar za ljudska prava, 2006) <= International Human Rights Law (Belgrade: Belgrade Centre for Human Rights, 2006)>; Dragoljub Popović, Evropski sud za ljudska prava, (Beograd: Službeni glasnik, 2008) <= European Court of Human Rights (Belgrade: Official Herald, 2008)>; Dragoljub Popović, Evropsko pravo ljudskih prava (Beograd: Službeni glasnik, 2012) <= European Human Rights Law (Belgrade: Official Herald, 2012)>; Dragoljub Popović, Postanak evropskog prava ljudskih prava - esej o sudskoj kreativnosti (Beograd: Službeni glasnik, 2013) <= The Emergence of the European Human Rights Law - An Essay on Judicial Creativity (Belgrade: Official Herald, 2013)>; Milan Paunović, Borislav Krivokapić, Ivana Krstić, Osnovi međunarodnih ljudskih prava (Beograd: Pravni fakultet Univerziteta u Beogradu, 2013) <= Foundations of International Human Rights Law (Belgrade: Faculty of Law University of Belgrade, 2013)>.

602 Bar Exam Act, Official Herald of the Republic of Serbia, no. 16/1997, Article 3.

603 As it was emphasized (section 2.3. supra), the Judge's Act stipulates that when the Court's judgment establishes that human rights and fundamental freedoms were violated in the course of a judicial proceeding, the Republic of Serbia may demand that the judge remunerates the awarded compensation, if the violation was caused willfully or by gross negligence.

${ }^{604}$ Cf. http://www.pars.rs/ (last visited 25 September 2013).

605 See section 4.1., supra.

${ }^{606}$ See section 7., infra.

607 E.g. Belgrade Centre for Human Rights, Helsinki Committee in Serbia, and the Lawyers' Committee for Human Rights (YUCOM). 
that in no less than 500 cases it referred to the Strasbourg Court's judgments, adjudicating in different types of proceedings (constitutional complaints, normative control, banning of political organizations, and complaints of non-appointed judges), and intervening in various human rights areas (political pluralism, equality before the law, due process and civil rights). ${ }^{608}$

Although, at first glance, this score may appear significant, especially for a court which has been in function with its new jurisdiction, encompassing the constitutional complaint proceedings, for little more than five years, a closer scrutiny of its work reveals certain discrepancies in its rulings. The relying on the Convention case-law has not always been consistent, ranging from its incoherent application in some important cases, e.g. banning of political organizations (7.1), to mechanically over-citing it in the clone ones, e.g. length of proceeding cases. ${ }^{609}$ While the Constitutional Court demonstrated the ability and readiness to use the Strasbourg case-law as a tool for enhancing the human rights protection in Serbia, e.g. administrative recognition of the sex adjustment (7.4), it was not too enthusiastic as regards some concepts, e.g. discrimination (7.2). Finally, the Constitutional Court's rulings which are well grounded in the Convention law sometimes seem to be the consequence of certain societal pressures, e.g. reform of the judiciary (7.3).

There is a visible impact of the Convention case-law on the democratization and rule of law in Serbia, but it remains doubtful whether it had reached a satisfactory level. The main criticism which the Constitutional Court, following the Strasbourg Court's jurisprudence, regularly and rightly addresses to the ordinary courts in the Serbia, reproaching inconsistency and lack of foreseeability, equally applies to its own case-law.

\subsection{Political Pluralism}

The collapse of the single party system, in Central and Eastern Europe, in 1989/1990, was accompanied by an immediate (re)introduction of political pluralism. The question of the legal status of political parties and associations then emerged. It included the definition of the limits of their activities for the prevention of those whose aim was to do away with the foundations of the democratic political system. The abolition of the political censorship, existing under the previous regime, resulted not only in promotion of democratic pluralism, but also in the growth of political extremism and hate speech. It has been rightly observed that in the 1990s, while "Central and East European countries were only gradually moving towards harmonization of their national economies, law, and political systems with European Union standards, they had been 'fully integrated' into the dark spirit of European racism and nationalism". ${ }^{610}$

Fitting into these Central and East European trends, in Serbia, in little less than three years (20082011), four proposals for the ban of extremist associations were filed with the Constitutional Court. In two of these cases the Court upheld the proposals, and it banned the given associations; ${ }^{611}$ in one case, it rejected the proposal; ${ }^{612}$ and, in another one, it declared the proposal inadmissible. ${ }^{613}$ Taken together, these rulings witness to some extent the inconsistency of the Constitutional Court's reasoning. This can be exemplified by the two bans - of Nacionalni stroj (7.1.1.) and of Obraz (7.1.2.)

${ }^{608}$ The figure is provided by the Official Herald of Republic of Serbia's electronic date-base search engine: www.e-glasnik.rs

${ }^{609}$ For instance, Belgrade Centre for Human Rights' Report indicates that "some of the references [made by the Constitutional Court in respect of the Convention case-law] appear indiscriminate and unspecific at times". Human Rights in Serbia 2012, p. 29.

610 Jiri Priban and Wojciech Sadurski, 'The Role of Political Rights in the Democratization of Central and Eastern Europe', in Wojciech Sadurski (ed.), Political Rights under Stress in 21 $1^{\text {st }}$ Century Europe (Oxford: Oxford University Press, 2006), p. 219.

${ }^{611}$ Ruling of the Constitutional Court, VIIU no. 171/2008, 2 July 2011; Ruling of the Constitutional Court, VIIU no. 249/2009, 12 June 2012.

612 Ruling of the Constitutional Court, VIIU no. 482/2011, 14 November 2012.

${ }^{613}$ Decision of the Constitutional Court, VIIU no. 279/2009, 17 March 2011. 
- which diametrically differ when it comes to their entrenchment in the Convention case-law. 614 However, the constitutional framework in this field corresponds to the European standards, and provides that "secret and paramilitary associations shall be prohibited", as well as that "the Constitutional Court may ban only such associations whose activity aims at violent overthrow of constitutional order, violation of guaranteed human or minority rights, or inciting of racial, national or religious hatred". ${ }^{615}$

\subsubsection{Nacionalni stroj (National Order) Case}

In its proposal for the ban the Public Prosecutor of Serbia classified Nacionalni stroj as "a 'secret political organization' whose activities aimed at incitement of racial and ethnic hatred" ${ }^{616}$ It was alleged that the members of that secret association were spreading racial and ethnic hatred by advocating supremacy of the white race and a superior position of the Serbian ethnicity, thereby directly violating constitutionally protected rights and freedoms. ${ }^{617}$ Accepting the qualification of Nacionalni stroj as a secret association whose activities were banned by the Constitution, the Constitutional Court (a) prohibited Nacionalni stroj to register either as a political party or as an association, (b) prohibited the organization to act, promote and spread its program aims and ideas, and (c) obliged state institutions to impose further measures to implement these prohibitions. ${ }^{618}$

The Court's classification of Nacionalni stroj as a secret organization was based on the following premises: it had pursued unconstitutional and illegitimate aims; it had actively worked on their achievement; and, a part of that strategy had been to act secretly. The aim of the association had been, inter alia, to establish a unitary Serbian ethnic state which would have secured the existence and renaissance of the Serbian nation with its Slavic Arian heritage. The basic principles of such a state would have been "the racial and biological protection of people", and "a full right of citizenship would have had only the loyal members of our country who had belonged to the white Arian race, while the citizens who had not been of white race and who had been racially mixed would have had a defined status and certain rights". ${ }^{619}$

As to the secret nature of the organization, the Court reached its conclusion on the grounds of the provisions contained in the organization's constitutive documents. The provisions recommended personal contacts between members and avoiding telephone communication, forbade publishing of photos of its members, as well as revealing of plans of activities to non-members. ${ }^{620}$ The Court found that the organization deliberately remained unregistered, because its members wished their activities to stay out of public reach, due to their illegal nature. The way that was chosen for performing activities aimed at hampering the authorities to take appropriate legal measures against the organization and its members. ${ }^{621}$ This was sufficient for the Constitutional Court to classify the Nacionalni stroj as a secret organization, and to ban it. ${ }^{622}$

By classifying Nacionalni stroj as a secret organization and banning it on that ground, the Constitutional Court avoided to examine the necessity of such a restrictive measure in a democratic society - the existence of the pressing social need and the proportionality of the given restriction (among other authorities see: Dicle pour le Parti de la Démocratie (DEP) c. Turquie, par. 62-63). The

\footnotetext{
${ }^{614}$ For more information on the given rulings of the Serbian Constitutional Court see: Tanasije Marinković, 'Wrestling with political extremism - Closure of Associations in the Case-Law of the Serbian Constitutional Court', (2012) 4 European Public Law Review/Revue européenne de droit public.

615 Constitution, Article 55 (3) and (4)

${ }^{616}$ Ruling of the Constitutional Court, VIIU no. 171/2008, Part I.

617 Ibid.

618 Ibid., Part VI.

619 Ibid., Part V.

${ }^{620}$ Ruling of the Constitutional Court, VIIU no. 171/2008, Part V.

$621 \mathrm{lbid}$.

622 Ibid.
} 
Court did not consider Nacionalni stroj to be a typical association, but rather a secret organization, arguing it by the fact that it was not registered, as well as by the non-transparent methods of work and communication of its members. Such an approach can be explained, on one hand, by the Constitutional Court's previous ruling in which it declared itself incompetent to ban an unregistered association. ${ }^{623}$ On the other hand, it was based on the stance that the banning of Nacionalni stroj was legitimate. Hence, the Constitutional Court engaged itself in an arduous endeavor of proving that Nacionalni stroj - an association which acted publicly, and had its website - was a secret organization, prohibited ex constitutione. ${ }^{624}$

Another approach of the Constitutional Court could have been to follow the well-established Convention case-law, classify the Nacionalni stroj as an association, albeit unregistered, and to ban it with the full respect of the conditions set out in the second paragraph of Article 11. Namely, it is considered under the Convention that although "an association's legal personality is dependent on its registration, an unregistered association can nevertheless be freely formed and engage in certain activities, just as it can possess funds through its members". ${ }^{625}$ In other words, even if an association is not registered, it is nonetheless an association with some legal capacity. When it comes to the Strasbourg Court's standards in the field of association ban, the Constitutional Court showed a greater concern for those in its Ruling on the ban of Obraz.

\subsubsection{Obraz (Cheek) Case}

In the proposal for the ban of Obraz the Public Prosecutor of Serbia invoked several legislative grounds for such a measure, but only two seemed to have been fully substantiated - activities of the association aimed at violation of human and minority rights, and incitement of national and religious hatred. 626 The Public Prosecutor invoked, inter alia, a program document of the association entitled "To the Serbian Enemies" (displayed on the website of the Association), the statements of its leaders given to the media shortly before the planned "Pride Parade", as well as causing disorder and violence for which the leaders of the association were sentenced by the ordinary courts. Relying on the Court's jurisprudence for the notion of hate speech and conditions for banning political organizations the Constitutional Court banned Obraz on 12 June 2012.

In the reasoning of its ruling the Constitutional Court particularly took into account the given program document of the association, ${ }^{627}$ as well as the statements of its leaders ${ }^{628}$ and the various incidents in which its members participated ${ }^{629}$ from which the association did not distance itself. After establishing the activities of the association which were contrary to the proclaimed constitutional values, the Court entered into analysis of the existence of the pressing social need for

623 Decision of the Constitutional Court, VIIU no. 279/2009.

624 For the critique of this approach, and for an attempt to define the notion of a secret association, see: Tanasije Marinković, "Wrestling with Political Extremism - Closure of Associations in the Case-Law of the Serbian Constitutional Court", op. cit.

625 Larmela against Finland, Decision of the European Commission of Human Rights, May 281997.

626 Ruling of the Constitutional Court, VIIU no. 249/2009, Part I.

627 In a particularly indicative document entitled "To the Serbian Enemies" the whole groups, whom the association considers as the enemies of the Serbian nation, are stigmatized (e.g. "Zionists, i.e. anti-Christian Jewish racists", "Ustashas", "Muslim extremists", and "Shqiptar terrorists"). Ruling of the Constitutional Court, VIIU no. 249/2009, Part IV.

628 In the statements and interviews the representative of the association threatens, "if the homosexuals have no shame, they will be prevented like in 2001" (a Belgrade daily, 'Press', September 1 2007), which means in the same way in which the assembly of the LGBT population was prevented in 2001, when the public order and peace were seriously disturbed, the objects and police vehicle were destroyed, one policeman was heavily injured, and ten people were lightly injured". Ibid.

${ }^{629}$ For example, on 10 December 2007, 30 activists of the association disturbed the registered public assembly entitled "Stop to the Clericalization", organized by the "Women in Black" and other non-governmental organizations... by chanting "Knife, wire, Srebrenica" and "Kill, kill a Shqiptar". Ibid. 
the restriction of freedom of association, and whether such a radical measure was proportionate to the legitimate aims pursued.

The Court found the existence of the pressing social need in the model of the society, based on discrimination of the given ethnic, religious, sexual and other groups, for which the association militated resorting to violence, the use of hate speech, and humiliating treatment. ${ }^{630}$ The proportionality of the ban was based on referring to "a difficult historical period through which Serbia went relatively recently, which was overburdened by the wars provoked by the ethnic and religious confrontation of the peoples in the region". The Constitutional Court noted that the "democratic pluralistic society which was being built [in Serbia] was still overburdened by numerous prejudices which had their deep roots in the history of the peoples on the Balkans". ${ }^{631}$ It also took into account that the association continued violating human and minority rights and provoking ethnic and religious hatred in spite of different measures which the responsible state authorities (police, public prosecutors and courts) undertook against its members. Since these measures proved to be inefficient, the Court sentenced Obraz to the most rigorous measure in the domain of freedom of association.

The Constitutional Court entirely based its ruling on the Convention case-law. Thus, it referred to Féret c. Belgique and Vejdeland and others $v$. Sweeden to show how much the understanding of hate speech has evolved in the Court's case-law, and to support its stance that the program of Obraz and its activities contained the elements of it. ${ }^{632}$ The Constitutional Court applied the Strasbourg criteria for banning an association, and especially the conditions under which the activities of association leaders could be attributed to the association itself, it relied on the Refah v. Turkey and Herri Batasuna v. Spain. ${ }^{633}$

\subsection{Equality before the Law}

In constitutional democracies, the equality before the law principle is one of the most important vehicles for judicial review. Its worldwide application is explained, inter alia, by an increasing influence of the international human rights law, including the Convention case-law. ${ }^{634}$ The Constitution of Serbia enshrines the principle of equality before the law, as well as prohibition of discrimination: "Everyone shall be equal before the Constitution and law. Everyone shall have the right to equal legal protection, without discrimination. All direct or indirect discrimination based on any grounds, particularly on race, sex, national origin, social origin, birth, religion, political or other opinion, property status, culture, language, age, mental or physical disability shall be prohibited". ${ }^{635}$ However, the Constitutional Court's interpretation and application of these provisions does not seem to be always in line with the Convention case-law. The Constitutional Court on the one hand does not recognize open differences in treatment, which risk being classified as discrimination, if they are not properly justified (7.2.1.). On the other hand in cases in which it admits the differences in treatment, it sometimes does not examine properly the criteria for establishment of (non)discrimination, set out in the Court's jurisprudence (7.2.2.).

\footnotetext{
630 Ibid., Part VI.

631 Ibid.

632 Féret c. Belgique, no. 15615/07, 16 July 2009, and Vejdeland and others v. Sweden, no. 1813/07, 9 February 2012.

${ }^{633}$ Refah partisi and others v. Turkey, nos. 41340/98 et seq., 13 February 2003, and Herri Batasuna et Batasuna c. Espagne, nos. 25803/04 and 25817/04, 30 June 2009.

634 Brun-Otto Bryde and Michael Ashley Stein, 'General provisions dealing with equality', in Mark Tushnet, Thomas Fleiner, Cheryl Saunders (eds.), Routledge Handbook of Constitutional Law (London and New York: Routledge, 2013), pp. 288 and 293.

635 Constitution, Article 21 (1), (2) and (3).
} 


\subsubsection{Nationality Act}

The Constitution provides that "the Republic of Serbia shall protect the rights and interests of its nationals abroad", but it also specifies that "the Republic of Serbia shall develop and promote relations of the Serbs living abroad with the kin state". ${ }^{636}$ This somehow introduces a certain amount of distinguishing between nationals on the ethnic basis.

The Nationality Act stipulates that a member of the people or of an ethnic group from Serbia can acquire Serbian nationality, within two years of the entry into force of the given act. ${ }^{637}$ However, these time limitations do not exist for an ethnic Serb who does not have a residence in Serbia, and who wishes to become a Serbian national. ${ }^{638}$ Under the same favorable terms a nationality may be sought by a person who was born in one of the republics of the former SFR Yugoslavia, who had a nationality of that republic or who is a national of one of the states created on the territory of Yugoslavia, and who, as a refugee, persecuted or displaced person, lives in Serbia or has exiled abroad. ${ }^{639}$

In an abstract review of constitutionality which was brought before it, the Constitutional Court disregarded this difference of treatment and upheld the constitutionality of the disputed legislative provision, considering that "the Constitution [did] not guarantee the right to nationality under 'privileged' or 'less demanding regime', only on the basis of the expression of will, and without satisfying any other conditions... as a result of which the question of violation of the principle of prohibition of discrimination [did] not arise" ${ }^{640}$ It was indeed not the Constitution, but an act of Parliament at the origin of the distinction made on ethnic grounds, between those living in Serbia. The Constitutional Court's ruling seems not to have provided a sufficient justification for it. ${ }^{641}$

\subsubsection{Churches and Religious Communities Act}

The Churches and Religious Communities Act was adopted by the National Assembly of Serbia in 2006, only few months before the popular embracement of the 2006 Constitution. It specifies the legal status and activities of churches and religious communities, as well as other aspects of the freedom to manifest one's religion. The Act introduces two different systems of registration of churches and religious communities: a system of declaration and a system of authorization. ${ }^{642}$ The former applies to traditional churches and religious communities, recognized as such by the Act itself, ${ }^{643}$ whereas the latter applies to all other churches and religious communities wishing to register. A traditional church or religious community is entered into Register upon submitting its name and seat, as well as the name and the seat of the person authorized to represent it. ${ }^{644}$ Other religious organizations are expected to submit in addition to this, some specific documents. Those are: the decision on establishment of the organization, with signatures of at least $0,001 \%$ citizens of

\footnotetext{
636 Ibid., Article 13 (1) and (2).

637 Nationality Act, Official Herald of the Republic of Serbia, nos. 135/2004 and 90/2007, Articles 18 and 23 (3).

638 Ibid., Article 23 (1)

639 Ibid., Article 23 (2)

${ }^{640}$ Ruling of the Constitutional Court of Serbia, IUz 564/2011, 18 January 2012.

${ }^{641}$ See the Dissenting Opinion of Justice Marija Draškić, in the Ruling of the Constitutional Court of Serbia, IUz $564 / 2011$. The authors of this text disagree in the assessment of the ruling commented here. While Dragoljub Popović is basically favourable to the approach expressed by the majority, Tanasije Marinković is supportive of the dissenter's position.

${ }^{642}$ For more information on the Act, see: Tanasije Marinković, 'Le traitement juridictionnel des discriminations religieuses en Serbie', in Elisabeth Lambert Abdelgawad et Thierry Rambaud (sld.), Analyse comparée des discriminations religieuses en Europe, (Strasbourg: Société de législation comparée, 2011), pp. 155-172.

${ }^{643}$ Serbian Orthodox Church, Roman Catholic Church, Slovak Evangelical Church, Reformed Christian Church, Evangelical Christian Church, Muslim Community and Jewish Community. Churches and Religious Communities Act, Official Herald of the Republic of Serbia, no. 36/2006, Article 10.

644 Ibid., Article 18
} 
the Republic of Serbia, according to the latest census, or foreign nationals with permanent residence in Serbia; the statute of the religious organization providing for its organizational structure; information on the fundamentals of religious teaching, religious rites and basic activities of the religious organization; and the information on the permanent financial sources. ${ }^{645}$

The Constitutional Court recognized the difference in treatment between the two groups of religious organizations, and raised the question of discrimination of the less favoured group. ${ }^{646}$ In doing so the Constitutional Court referred to the Belgium Linguistic Case, and to the Jehovah's Witnesses Case, both judgments rendered by the Court.

Relying on the Belgium Linguistic Case, the Constitutional Court concluded that "the principle of equality of treatment is violated if the distinction has no objective and reasonable justification" as well as if "there is no reasonable relationship of proportionality between the means employed and the aim sought to be realised". ${ }^{647}$ With reference to the Jehovah's Witnesses Case, the Constitutional Court underlined that a waiting period for a religious association to obtain status as a public-law body, could not be considered as justified in respect of religious groups with a long-standing (international and national) existence, being as such familiar to the competent authorities. ${ }^{648}$ The Constitutional Court thus retained from the Strasbourg Court's jurisprudence that the prohibition of discrimination did not forbid national authorities from treating groups differently in order to correct "factual inequalities" between them. The right not to be discriminated could also be violated when States, without an objective and reasonable justification, failed to treat differently persons whose situations were significantly different. ${ }^{649}$

Applying these principles to the given case, the Constitutional Court found that the Act was adopted, inter alia, so that the state could create a central registry of religious organizations for which it needed specific information on these very organizations, and therefore required their registration. As the traditional churches and religious communities had already acquired the legal status by the legislation of the Kingdom of Serbia and Kingdom of Yugoslavia, their registration was not needed since the state authorities already possessed necessary information about them, which justified the difference in treatment. ${ }^{650}$

However, the Constitutional Court did not enter into the examination of the proportionality of the given legislative measure. Had it done so, it would have had to respond why the continuity of legal capacity was not recognized to any religious organization which had been registered under the communist regime. Some claim that it is not evident that even the purpose of the differentiation satisfies the test of objectiveness and reasonableness. Namely, it does not transpire from the individual acts by which the traditional churches and religious communities acquired their legal status that the state required from them all the information which the non-traditional religious organizations are expected to provide in order to be recognized, under the legislation which is currently in force. ${ }^{651}$

It should nevertheless be pointed out that the position taken by the Constitutional Court on this particular issue, if considered from the standpoint of the Convention standards, is based on the

\footnotetext{
645 Ibid.

${ }^{646}$ Ruling of the Constitutional Court of Serbia, IUz 455/2011, 16 January 2013.

647 Case "relating to certain aspects of the laws on the use of languages in education in Belgium" v. Belgium, no. 1474/64 et seq., 23 July 1968, section I B, para. 10.

${ }^{648}$ Religionsgemeinschaft der Zeugen Jehovas and Others v. Austria", no. 40825/98, 31 July 2008, paras. 60 63 and $92-99$.

${ }^{649}$ Belgium Linguistic Case, para. 10; Thlimmenos v. Greece, no. 34369/97, 6 April 2000, para. 44.

650 Ruling of the Constitutional Court of Serbia, IUz 455/2011, 16 January 2013.

651 See the Dissenting Opinion of Justice Marija Draškić, in the Ruling of the Constitutional Court of Serbia, IUz $455 / 2011$.
} 
margin of appreciation of the Member States. The advantage granted to the traditional religious communities falls within its scope. ${ }^{652}$

\subsection{Due Process of Law 653}

In the first five years of its functioning under the new Constitution, the Constitutional Court was confronted with some of the major political and legal challenges in nascent democracies - resetting of the institutions in the process of democratic transition and consolidation. One of those was the reform of the Serbian judiciary. Its most sensitive element was the demise of all sitting judges in the country. The Judges Act, adopted in December 2008 provided for the termination of tenures of all judges. The judges were in the position to apply for their offices and the High Council of the Judiciary was competent to rule on their new appointment to the office. Several hundreds of judges who were not appointed filed complaints with the Constitutional Court. They first claimed unconstitutionality of the 2008 Judges Act in an abstract review of constitutionality.

The Constitutional Court first ruled that the Judges Act was in conformity with the Constitution. 654 Then, throughout 2009 and 2010, it ruled on the complaints, which the judges who were not appointed under the 2008 legislation filed with it. The complaints were filed in respect of individual rulings given by the High Council of the Judiciary, on 25 December 2009, refusing appointment to office. The Constitutional Court adjudicated in favour of the procedural rights of judges in the proceedings they had previously brought before the High Council of the Judiciary, relying on the fair trial standards set out in the Convention and developed by the Court.

The Constitutional Court's approach to the cases of this kind deserves our interest. ${ }^{655}$ It was based on the Convention case-law and the landmark rulings were given in Saveljiić (7.3.1) and Tasić (7.3.2).

\subsubsection{The Ruling in Saveljic}

On May 28 2010, the Constitutional Court delivered its first ruling in a case of a non-appointed judge. ${ }^{656}$ It held for the complainant and annulled the Decision of the High Council of the Judiciary. The Constitutional Court ordered that body to revisit the complainant's case within 30 days.

The Judges' Act (Article 45), stipulated a presumption according to which a judge who had been appointed under the previous rules, and had exercised a judicial function in the moment of the general reappointment, as well as who applied to a court of the same type, i.e. same rank, was supposed to fulfil the standards' requirements. The presumption could nevertheless be overruled. The Constitutional Court found that the mentioned legislative provision gave a right to the complainant to receive a reasoned decision of the High Council of the Judiciary, which lacked in the case. ${ }^{657}$

In reaching this conclusion the Constitutional Court relied on the Court's case-law under article 6 (1) of the Convention, and in particular on Salov v. Ukraine and Hadjianastassiou v. Greece. ${ }^{658}$ The

\footnotetext{
652 Here again the authors of this text disagree. Dragoljub Popovic is favourable to the majority ruling, whereas Tanasije Marinkovic is in favour of the dissenting opinion.

653 This section of the paper is partially reproduced from: Violeta Beširević and Tanasije Marinković, 'Serbia in a Europe of Rights: The Effects of the Constitutional Dialogue between the Serbian and European Judges', (2012) 1 European Review of Public Law / Revue Européenne de Droit Public.

654 Decision, no. IUz 43/09, 9 July 2009, Part VII.

655 For more information on the political context and the role of the Constitutional Court of Serbia in the reform of the judiciary, see: Tanasije Marinković, 'Politics of Constitutional Courts in Democratizing Regimes', Miodrag Jovanović and Kenneth Einar Himma (eds.), Courts, Interpretation, the Rule of Law, (Utrecht: Eleven International Publishing, 2013).

${ }^{656}$ Ruling of the Constitutional Court, no. VIIIU-102/2010, 28 May 2010. Further in the text: the Saveljić Ruling. 657 Ibid., Part VI.

658 Salov v. Ukraine, no. 65518/01, 6 September 2005, and Hadjianastassiou v. Greece, no. 12945/87, 16
} 
Constitutional Court referred to Salov in which the Court considered that the applicant had not had the benefit of fair proceedings because the domestic courts had given no reasoned answer as to why the District Court had originally found no evidence to convict the applicant of the offences he had been charged and had remitted the case for additional investigation, and yet, later on, found the applicant guilty. ${ }^{659}$ The Constitutional Court followed the Court's standing that the lack of a reasoned decision hindered the applicant from raising the pertinent issues at the appeal stage. ${ }^{660}$ From the Hadjianastassiou the Constitutional Court deduced that the applicant could not benefit from the right to a fair trial in an instance where he had not been served the full text of the judgment ("finalized version") before the expiry of the time-limit for the appeal. ${ }^{661}$

\subsubsection{The Ruling in Tasić}

Pursuant to the Saveljić Ruling, the High Council of the Judiciary delivered on 14 June 2010 reasoned decisions, nevertheless unfavourable to the judges whose office had been terminated. The judges filed once again with the Constitutional Court. This time they claimed that the facts of their cases had not been established, that the procedure had not been conducted publicly, in a contradictory way and impartially, and, as a result, that the decisions had not been properly reasoned.

The Constitutional Court delivered the Tasić Ruling, by which it upheld the complaint. The Court annulled the Decision of the High Council of the Judiciary of 25 December 2009, to the extent to which it concerned the appellant, and the individualized decision of the Council delivered to the appellant only, on 14 June 2010, and it ordered the Council to revisit the case. ${ }^{662}$ Namely, in the Tasić Ruling the Constitutional Court found that instead of reopening the procedure, as prescribed by the Saveljić Ruling, the High Council of the Judiciary delivered an individual decision on the termination of the appellant's office without reasoning it properly. By such a decision it replaced its previous single Decision of 25 December 2009.663

Corroborating and nuancing its arguments, stated in the Saveljić Ruling the Constitutional Court invoked, once again, the jurisprudence of the Court, only this time not as to the substance of the right to a fair trial, but with regard to the scope of application of this right, and to the autonomous meaning of the concept of a court. The Court relied in particular on Eskelinen and Others v. Finland, and even more on Olujić v. Croatia. ${ }^{664}$ Namely, in the latter, the Court considered the Croatian National Judicial Council to be a court due to the disciplinary procedure which was held before it. The Constitutional Court concluded that the procedure in which the High Council of the Judiciary delivered the disputed decisions equally had to be conducted in accordance with Article 32 of the Constitution which guaranteed the right to a fair trial. ${ }^{665}$

\subsection{Civil Rights}

The influence of the Convention case-law on the Constitutional Court's jurisprudence has been the most significant in the field of civil rights. The Constitutional Court has even tended to introduce some new rights, by relying on the well-established case-law of the Court. That was particularly the case with the right to recognition of sex adjustment, which the legislation in force did not allow for, so the Constitutional Court had to fill in this normative gap.

\footnotetext{
December 1992.

659 The Saveljić Ruling, Part VI.

660 See Salov v. Ukraine, para. 92.

${ }^{661}$ Hadjianastassiou v. Greece, paras. 34 and 37.

662 Ruling, no. VIIIU-189/2010, 21 December 2010, Part XII. Further in the text: the Tasić Ruling.

663 Ibid., Part IX.

${ }^{664}$ Eskelinen and Others v. Finland, no. 63235/00, 19 April 2007, and Olujić v. Croatia, no. 22330/05, 5 February 2009.

665 See the Tasić Ruling, Part VIII.
} 
The case originated in a constitutional complaint which was submitted by X, born in 1949, and diagnosed with the pseudohermaphroditism, i.e. physical characteristics of the female sex and the gender identity of the male sex. After receiving different therapies, $X$ had the sex reassignment surgery in Belgrade, in December 2010. In March 2011 he sought from the municipal authorities, responsible for keeping the registry of birth, the rectification of the data related to his sex. The request was dismissed. He filed a constitutional complaint, against the dismissal. The Constitutional Court found for the complainant and ordered the authorities to alter the data related to sex in the registry of birth. 666

The Constitutional Court referred to a number of the Court's judgments in which it found that there had been no administrative or judicial remedy at the applicant's disposal under domestic law. ${ }^{667}$ It referred, in particular: to Vernillo v. France and Lepojić v. Serbia, for its holding that the remedy had to be sufficiently certain, not only in theory, but also in practice. ${ }^{668}$ It made reference to Chahal $v$. The United Kingdom, in arguing that remedy should be of such a nature as to allow the competent authority both to deal with the substance of the relevant infringement and to grant appropriate relief. ${ }^{669}$ It referred to Airey $v$. Irland, stating that when there were several remedies available it was up to the victim to choose the one it wanted to use; ${ }^{670}$ as well as to Akdivar v. Turkey, in its holding that the redress should have reasonable prospects of success. ${ }^{671}$

Concerning the recognition of the right to have one's sex adapted to his/her gender identity, as an inherent element of the right to respect for private life, the Constitutional Court had to recognise the right to respect for private life, which was not as such enshrined in the 2006 Constitution. ${ }^{672}$ The Constitutional Court construed this right from the constitutional guaranty of "dignity and free development of individuals". ${ }^{673}$ Supporting the inclusion of the right to respect for private life into the constitutional guarantee of dignity and free development of individuals, the Court resorted to the understanding of the notion of "respect for private life" in the Convention case-law. In particular, it quoted the Court's holding that the "respect for private life must also comprise to a certain degree the right to establish and develop relationships with other human beings". ${ }^{674}$

The Constitutional Court also referred to the Convention case-law, for its notion of private life which implied "a physical and moral integrity of a person" together with "his or her sexual life". ${ }^{675}$ The Constitutional Court held that "the sphere of private life of a person undoubtedly includes, inter alia, its sexual identity, sexual orientation and sexual life, as a result of which a right to a private life presupposes a right to have the details of personal identity specified, and in that sense a right to have one's sex adapted to its gender identity". ${ }^{676}$ The Constitutional Court concluded that "although neither the Constitution nor the European Convention [on Human Rights] explicitly mention gender identity and the right to a change of sex, this sphere of person's life undoubtedly belongs to a constitutionally guaranteed sphere of dignity and free development of individuals and conventionally guaranteed sphere of respect for private life". 677

\footnotetext{
${ }^{666}$ Ruling of the Constitutional Court, no. Uz-3238/2011, 8 March 2012, Part III.

667 Ibid., Part V.

668 Vernillo v. France, no. 11889/85, 20 February 1991, para. 27; Lepojić v. Serbia, no. 13909/05, 6 November 2007, para. 51.

${ }^{669}$ Chahal v. The United Kingdom, no. 22414/93, 15 November 1996, para. 145.

670 Airey v. Irland, no. 6289/73, 9 October 2010.

${ }^{671}$ Akdivar v. Turkey, no. 21893/93, 16 September 1996, para. 68.

672 Ruling of the Constitutional Court, no. Uz-3238/2011, Part VI.

${ }^{673}$ Constitution of Serbia, Article 23 (1) and (2).

${ }^{674}$ Niemietz v. Germany, no. 13710/88, 16 December 1992, para. 29.

${ }^{675} X$ and $Y v$. The Netherlands, no. 8978/80, 26 March 1985, para. 22.

676 Ruling of the Constitutional Court, no. Uz-3238/2011, Part VI.

677 Ibid., Part VII.
} 
Consequently, after recognizing the right to have one's sex adapted to its gender identity, as a constitutionally entrenched right, the Constitutional Court introduced a positive obligation for the authorities to make necessary alterations in the birth registry. ${ }^{678}$ Such a rectification should be allowed, upon request of the person concerned, supported by the documentation adduced by the medical institution, which effectuated the sex reassignment surgery. ${ }^{679}$ In extending, in this respect too, the boundaries of individual rights the Constitutional Court found, once again, a necessary support in the Convention case-law, i.e. in the judgment given in Goodwin v. The United Kingdom. ${ }^{680}$

\section{INFLUENCE OF THE CASE-LAW IN RELATION TO SERBIA ON THE COURT'S OVERALL JURISPRUDENCE}

Being one of the youngest Parties to the Convention, the case-law in relation to Serbia hasn't had so far a significant impact on the Court's overall jurisprudence. Still, a number of important cases have been decided against it. For example, its recent judgment, Youth Initiative for Human Rights $v$. Serbia, ${ }^{681}$ expands boundaries in the Convention case-law, and will probably influence it more broadly in the future. The given case concerned access to information obtained via electronic surveillance by the Serbian Intelligence Agency, involving thereby a right which until recently was not recognized under the Convention. ${ }^{682}$ Namely, the intelligence agency of Serbia refused to provide the applicant (an NGO - Youth Initiative for Human Rights) with the information on how many people had been subjected to electronic surveillance by that agency in 2005, notwithstanding a final and binding decision of the Information Commissioner in its favour. ${ }^{683}$

The Court's judgment, Youth Initiative for Human Right's v. Serbia, builds on the recent Convention case-law under Article 10 (in relation to Hungary). ${ }^{684}$ Following the Társaság a Szabadságjogokért v. Hungary (par. 27 and 35-36), the Court affirms that "the notion of 'freedom to receive information' embraces a right of access to information", and it reiterates that when a non-governmental organisation is involved in matters of public interest it warrants similar Convention protection to that afforded to the press. ${ }^{685}$ Furthermore, Youth Initiative for Human Rights demonstrates, alongside Kenedi $v$. Hungary (par. 44-45), that when the responsible adminstrative agency persistently ignors (quasi)judicial orders, the establishment of infringement of the freedom of expression stops short of examining the "prescribed by law" requirement. Thus, in Youth Initiative

\footnotetext{
678 Ibid.

679 Ibid., Part VIII.

680 Christine Goodwin v. The United Kingdom, no. 28957/95, 11 July 2002, para. 77.

${ }^{681}$ Youth Initiative for Human Rights v. Serbia, no. 48135/06, 25 June 2013.

682 As long ago as in 2009, an authoritative textbook in the Convention case-law acknowledged that "Article 10 has yet to be recognized by the Court as providing a basis for the right of access to information. It has consistently rejected the view that Article 10(1), which includes the phrase 'freedom... to receive... information', can be read to guarantee a general right of access to information". Harris, O'Boyle \& Warbrick, Law of the European Convention on Human Rights (Oxford: Oxford University Press, 2009), p. 447.

683 Youth Initiative for Human Rights v. Serbia, paras. 6-9.

684 Társaság a Szabadságjogokért v. Hungary, no. 37374/05, 14 April 2009, and Kenedi v. Hungary, no. 31475/05, 26 May 2009. In its Grand Chamber judgment, Gillberg v. Sweden, no. 41723/06, 3 April 2012, the Court restated, quoting Leander v. Sweden (par.74), that "the right to receive and impart information explicitly forms part of the right to freedom of expression under Article 10", and that "that right basically prohibits a Government from restricting a person from receiving information that others wish or may be willing to impart to him" (par. 83). Interestingly enough, the Court did not quote the continuation of paragraph 74 of the Leander judgment: "Article 10 (art. 10) does not, in circumstances such as those of the present case, confer on the individual a right of access to a register containing information on his personal position, nor does it embody an obligation on the Government to impart such information to the individual." For the implications of the present judgment in light of Gillberg v. Sweeden, see the Joint Concurring Opinion of judges Sajo and Vučinić in Youth Initiative for Human Rights v. Serbia.

685 Youth Initiative for Human Rights v. Serbia, para. 20.
} 
for Human Rights the Court does not even refer to the requirements set out in paragraph 2 of Article 10 ("prescribed by law", "legitimate aim" and "necessary in democracy"). It rather states that "restrictions ought to be in accordance with domestic law", and concludes, in light of the unpersuasiveness of the intelligence agency's response, ${ }^{686}$ that "the obstinate reluctance of the respondent State's authorities to comply with the execution orders was in defiance of domestic law and tantamount to arbitrariness". ${ }^{687}$

However, the Youth Initiative for Human Rights does not only reafirm the new Convention case-law in respect of a right of access to information, but it also goes beyond it by applying, for the first time in this context, Article 46 of the Convention. Therefore, after establishing that there had been a violation of the Convention, and on top of examining the applicant's claim for just satisfaction under Article 41 of the Convention, the Court considered what consequences could be drawn for the respondent State from Article 46. Deriving from that article a legal obligation for a respondent State to adopt the general and/or, if appropriate, individual measures in order to put an end to the violation and to redress so far as possible its effects, the Court found that "the most natural execution of its judgment, and that which would best correspond to the principle of restitutio in integrum, would have been to secure that the intelligence agency of Serbia provide the applicant with the information requested". ${ }^{688}$ Thus, though in principle, it was not for the Court to determine what measures could be appropriate to satisfy the respondent State's obligations under Article 46 of the Convention, the violation which had been found in this case, by its very nature, did not leave any real choice as to the measures required to remedy it.

\section{CONCLUSIONS}

The reception of the Convention and its accommodation into domestic law and legal practices proved to be a slow and complex process, varying across states and time. Challenges of the European Human Rights Law seem to have been an inspiration to various legislative reforms on the national levels, as well as to a fruitful dialogue between the Court and the national judiciaries, for the latter were ready to put their case-law in line with the Strasbourg jurisprudence.

Being one of the youngest Parties to the Convention, Serbia introduced necessary legislative reforms to allow for a successful integration of the Convention case-law in its legal order. The 2006 Constitution provides for a supra-legislative status of the Convention and its direct effect. The Constitution also entrenches the normative value of the Court's case-law in the interpretation of the fundamental rights and freedoms. The constitutional provisions on rights and liberties mirror in many respects those of the Convention, or even synthesize the well-established case-law of the Court.

The Constitutional Court of Serbia has the power to review the constitutionality and conventionality of laws and decrees, as well as of individual acts. Apart from these preventive mechanisms of coordination between the national and supranational levels, some ex-post instruments are also provided for. Re-opening of criminal, civil and administrative proceedings, at the initiative of successful applicant who had claimed violation of Convention rights in Strasbourg find their places among such instruments. While these mechanisms of judicial cooperation appear to be well

686 The Agency initially refused the request of the applicant, relying on the 2004 Freedom of Information Act which provided that "access to information of public interest [could] be refused, if its disclosure would... seriously undermine a legitimate interest which [had] priority over freedom of information". However, when the Commissioner found that the Intelligence Agency had breached the law and ordered that the information requested be made available to the applicant, the Agency notified the applicant that it did not hold the information requested. Youth Initiative for Human Rights v. Serbia, para. 7, 9 and 10.

687 Ibid., par. 25. See, also: Kenedi v. Hungary, para. 45.

688 Youth Initiative for Human Rights v. Serbia, para. 32. 
formulated, the legislative procedure could be improved, so that the conventionality of the bills is systematically examined by the competent parliamentary bodies.

However, upon a closer look at the practices of the courts in Serbia, a somewhat nuanced conclusion may be reached. The Court's case-law in respect of Serbia reveals that the Serbian judiciary suffers from systemic deficiencies, such as the non-enforcement of final judgments and non-harmonized case-law, which go contrary to some of the most important Convention values: fair trial, legal security and equality before the law. Although their practices show a visible shift of attitude towards the Strasbourg jurisprudence, the Serbian courts still do not follow the Convention case-law sufficiently and systematically. This explains, at least partially, why Serbia ranks among the top five on the Court's list of countries with the greatest number of applications filed against it. It may well be the case that deeper roots for this unflattering score should be sought elsewhere, primarily in the university teaching and scholarship which still underestimate the importance of the Convention case-law and its impact on the domestic legal system. Thereby a considerable portion of legal practitioners are being deprived of the necessary heuristic tools in applying the European Human Rights Law.

Analyzed against this background, the Constitutional Court's compliance with the Convention caselaw is noteworthy, and it should be put forward that it has had a positive impact on the democratization process in Serbia. ${ }^{689}$ The Constitutional Court's commitment to the Convention case-law has been particularly significant when it comes to civil rights, where it showed readiness to follow the Strasbourg jurisprudence as an instrument to fill in gaps in domestic legislation. Its role in the promotion of due process rights has been equally important, although at moments it appeared to be subject to societal pressures. The Constitutional Court's record as regards political liberalism has nevertheless been thinned by certain inconsistencies in legal reasoning.

${ }^{689}$ It should also be mentioned in this context that the Constitutional Court, just like its counterparts in Central and Eastern Europe, acted more as a guardian of provisions on rights, than as a guardian of the separation of powers, i.e. as a defender of liberal, rather than of a democratic constitutionalism. Cf. Wojciech Sadurski, Rights Before Courts - A Study of Constitutional Courts in Postcommunist States of Central and Eastern Europe (Dordrecht: Springer, 2005), p. 56. 


\title{
SLOVAKIA
}

\author{
Milan Blaško* and Michal Kučera*
}

\section{How the Convention has helped Slovakia in its transition to a consolidated democracy}

\section{Introduction}

It would be difficult to describe the impact of the Convention system on Slovakia without having in mind both the tumultuous developments the country went through in the past and the challenges it had to face as a new independent State established in 1993.

Alone in the course of the $20^{\text {th }}$ century the State's official name changed eight times and it experienced a variety of systems and types of government comprising monarchy, parliamentary democracy and totalitarian regime, unitary system of government, autonomy and federalism. The impact of those developments on the society and its members did not allow for a line to be drawn under the past in 1993. Furthermore, at that time there were many questions and doubts, such as to the economic viability of this new and relatively small State and its ability to develop and maintain a democratic system of government. Succession to the former Czechoslovakia, establishment at international level by means of bilateral diplomatic relations, transition to market-oriented economy, political and economic integration, setting up of democratic institutions, ensuring rule of law, position of minorities, civil society building or addressing wrongs which had been committed in the past were among the complex issues which needed to be addressed within a short span of time.

Slovakia's road towards democracy was often bumpy and imperfect, also due to the above multitude of issues which it had to face. From today's perspective, the progress achieved is undeniable. One of the decisive factors has been the fulfilment of several generations' dream which the lyrics of an emblematic song in Czechoslovakia phrased "May peace remain with this land, ... now that the lost rule over your affairs is to return to you, people"690.

Indeed, Article 1 of the Constitution defines Slovakia as a democratic State based on the rule of law. Article 2 stipulates that the power in the State stems from the citizens, limits the powers of authorities to what is set out in the Constitution and laws, and it entitles everybody to do anything which the law does not prohibit.

Putting those principles into practice after forty years of a totalitarian regime was not an easy task. Safeguards, including the possibility of seeking redress by legal means, have constituted one of the characteristic features of a democratic state of law ${ }^{691}$. The mechanism of collective enforcement of human rights and fundamental freedoms established under the Convention, albeit subsidiary in its nature, has had a non-negligible role to play in shaping the institutional and procedural attributes of the rule of law in Slovakia.

Thus during Slovakia's first twenty years of existence as an independent and democratic State the Convention mechanism was called upon to address issues which divided the society and had bearing on the functioning of the State bodies, democratic institutions or

690 'Prayer for Marta', recorded by the Czech singer Marta Kubišová shortly after the invasion of Czechoslovakia by the Warsaw Treaty countries' troops in 1968 which has become one of the symbols of the Velvet revolution of 1989 leading to the fall of the communist regime.

691 B. Repík: L'udské práva v súdnom konaní; MANZ, Bratislava, 1999, p. 9. 
the society. Termination of a Member of Parliament's office ${ }^{692}$ and the filling of a vacant seat in the Parliament ${ }^{693}$, revocation of a pardon on offences related to the abduction of the President's son abroad ${ }^{694}$, attempted revocation of the President of the Supreme Court ${ }^{695}$, restriction of the freedom of expression of a writer who criticised a Minister's past ${ }^{696}$ or conviction of a journalist for defamation of the highest representative of the Roman Catholic Church in Slovakia ${ }^{697}$ are examples of cases which attracted public attention.

Numerous other applications which did not reach the news headlines but permitted "ordinary" individuals to obtain redress are of no less importance. The case of a person who was entirely deprived of his legal capacity but managed to have his application determined on the merits and a breach of his Convention rights found despite the Government's objection that he lacked standing to take any legal action ${ }^{698}$, or cases of Roma women subjected to sterilization without their informed consent (described in more detail below) may be mentioned.

The scope of the present article does not allow for an exhaustive inventory to be drawn. It is therefore by way of example, with particular emphasis on the core provisions of the Convention, that it is attempted to describe how the Convention mechanism contributed to building up democracy and strengthening specific attributes of the rule of law in Slovakia.

The first decade following Slovakia's accession to the Convention has been described elsewhere ${ }^{699}$. Particular emphasis has therefore now been given to the developments in the second one ${ }^{700}$. That period largely coincides with the term of office of Judge Ján Šikuta. His professional knowledge, experience and human qualities played an important role in, among other areas, the Court's examination of applications against Slovakia. This text has been written in his honour.

\section{Status of the Convention in national legal order and protection by the Constitutional Court and ordinary courts of the Convention rights and freedoms}

Relevant elements of the constitutional system, circumstances of Slovakia's accession to the Convention and its status in domestic legal system are described in detail in the publication referred to above ${ }^{701}$, covering the period up to 2000. After that date a number of developments occurred some of which were prompted by Slovakia's accession to the European Union.

Thus with effect from 1 July 2001 Article 11 of the Constitution was repealed. It provided for international treaties on human rights to take precedence over national laws only where such treaties guaranteed a wider scope of human rights and fundamental freedoms. The newly introduced Article $7 \S 5$ of the Constitution has laid down unconditional precedence

\footnotetext{
692 Gaulieder (friendly settlement), no. 36909/97, 18 May 2000.

${ }^{693}$ Spišák (dec.), no. 43730/98, 7 December 2000.

${ }^{694}$ Lexa, no. 54334/00, 23 September 2008.

695 Harabin (dec.), no. 62584/00, ECHR 2004-VI.

${ }^{696}$ Feldek, no. 29032/95, ECHR 2001-VIII.

697 Klein, no. 72208/01, 31 October 2006.

${ }^{698}$ Matter, no. 31534/96; Commission's decision of 16 September 1997 and Court's judgment of 5 July 1999.

${ }^{699}$ M. Blaško: Chapter on Slovakia in Fundamental Rights in Europe; OUP (2001), pp. 755-779.

700 In that respect see also M. Mierzewska: The Reception Process in Poland and Slovakia, in A Europe of Rights: The Impact of the ECHR on National Legal Systems, OUP (2008).

${ }^{701}$ See supra note 11, pp. 755-765.
} 
over national laws of, inter alia, international treaties on human rights which were ratified and promulgated in accordance with the law. However, the 'stronger guarantee' requirement contained in former Article 11 has been maintained, in Article 154c $\S 1$ of the Constitution, in respect of international treaties on human rights which were ratified and promulgated prior to the constitutional amendment which took effect on 1 July 2001702, the Convention included. This does not affect the position of such treaties as integral part of Slovak legal order. Furthermore, Article $1 \S 2$ of the Constitution guarantees respecting by Slovakia of all its undertakings under international treaties.

Article $141 \S 1$ of the Constitution renders judges bound, inter alia, by international treaties on human rights in the exercise of their duties. The Constitutional Court has held that the Convention and its case-law constitute binding interpretation guidelines for domestic authorities in the context of interpretation and implementation of fundamental rights and freedoms laid down in the Constitution. The Convention thereby sets up a framework which those authorities cannot overstep ${ }^{703}$. It is primarily for the ordinary courts to ensure respect for human rights while exercising their powers and the Constitutional Court has limited its interference with proceedings and decisions of ordinary courts only to situations entailing a breach of fundamental rights ${ }^{704}$.

Pursuant to Article $144 \S 2$ of the Constitution, where a court considers that a legally binding legal rule bearing on the matter before it is contrary, among others, to an international treaty on human rights, it has to stay the proceedings and refer the matter to the Constitutional Court whose conclusion is binding. The Constitutional Court is empowered to review conformity of laws with treaties on human rights (Article $125 \S 1$ (a) of the Constitution). The circle of persons entitled to initiate such proceedings is limited (at least one fifth of the Members of Parliament, the President, the Government, courts, General Prosecutor or public defendant of rights). Where the Constitutional Court concludes that legal rules run contrary to international treaty on human rights, the provisions concerned lose their effect. The authorities have six months to bring such rules in conformity with the international treaty failing which they become null and void.

Such position obtained in the first two cases against Slovakia where the Court found a breach of the Convention. It was due to a statutory provision preventing the courts from reviewing administrative decisions in cases where a fine below a certain threshold had been imposed. In its judgment the Constitutional Court granted a direct effect to the Court's judgments and declared the relevant provision contrary to Article $6 \S 1$ of the Convention ${ }^{705}$.

Until 2002 the Convention organs did not consider recourse to the Constitutional Court, but for minor exceptions, as an effective remedy which the applicants had to use to comply with Article $35 \S 1$ (formerly Article 26) of the Convention. It was due to its lack of power to provide redress to successful plaintiffs ${ }^{706}$. The situation changed with an amendment introducing complaint under Article 127 of the Constitution. It entitles the Constitutional Court to provide redress by means of quashing an authority's decision, to remit the case to the authority concerned for further proceedings, to order it to take a particular action or to order restitutio in integrum. The Constitutional Court may further grant adequate financial satisfaction to a successful plaintiff. As a result, complaint under Article 127 of the Constitution has been considered as the ultimate remedy which needs to be exhausted in

\footnotetext{
702 Constitutional law no. 90/2001 Coll.

703 I. ÚS 36/02, judgment of 30 April 2003.

704 I. ÚS 150/05, decision of 23 August 2005.

705 Lauko and Kadubec; 2 September 1998, Reports of Judgments and Decisions 1998 VI, in conjunction with the Committee of Ministers' Resolutions DH (99) 553 and 554.

${ }^{706}$ See supra note 11, pp. 762-764.
} 
individual applications against Slovakia. Situations where the alleged breach stems from the lack of conformity of the legal provision applied with the Constitution or the Convention are the only exception. The reason is the Constitutional Court's stance that natural or legal persons lack standing to bring proceedings under Article 127 of the Constitution, which involve, as preliminary issue, the assessment of conformity of the relevant legal rules with the Constitution or international treaties ${ }^{707}$.

The approach of the Constitutional Court to complaints about a breach of the Convention rights or their constitutional equivalents has not always coincided with that of the Court ${ }^{708}$. Although it has not been considered as rendering that remedy ineffective, it certainly accounts for a part of the applications which reached the Court. In this respect, the following examples may be cited.

Practice as regards complaints about length of proceedings and the sometimes ambiguous relationship between the constitutional complaint and possible other remedies, in so far as exhaustion of ordinary remedies as a requirement for the admissibility of a constitutional complaint is concerned ${ }^{709}$.

Subjecting the examination of complaints under, e.g., Articles 3 and 8 to the complainant's explicit simultaneous invoking the procedural guarantees of Article $6^{710}$, and the premise that an ordinary court cannot bear 'secondary liability' for a breach of such rights unless there had been a constitutionally relevant violation of the rules of procedure ${ }^{711}$ or, in other words, that application of a statute in judicial proceedings in a manner consistent with the applicable procedural rules may not amount to a violation of fundamental rights and freedoms $^{712}$.

Subjecting of the examination of a constitutional complaint in a case concerning lack of an effective investigation into a matter falling within the purview of Article 3 to remedies under a statute governing the internal functioning of the Public Prosecution Service ${ }^{713}$.

\section{Applications against Slovakia - an illustrative overview}

\subsection{Caseload and scope}

The official statistics indicate that between 1993 and the end of 2012 a breach of the Convention by Slovakia was found in 260 cases. Further 180 cases have been resolved by way of a friendly settlement or a unilateral declaration.

In the last four years the number of applications against Slovakia assigned to a decision body within the Court was between 500 and 600 per year. They resulted in 41 judgments on the merits in 2010, 21 judgments in 2011 and 23 in 2012. Some 600 cases were pending before the Court at the beginning of 2013.

By far the highest number of violations found concerned the failure to ensure respect for one's right to a hearing within a reasonable time. Several breaches of the core provisions of

\footnotetext{
707 IV. ÚS 50/2010, decision of 5 February 2010.

708 See contribution by J. Šikuta in 'Prístup k spravodlivosti - bariéry a východiská 6'; Via luris (2006), pp. 4-5.

709 These problems are elaborated on below in this chapter.

710 V.C. (dec.), no. 18968/07, 16 June 2009.

711 IV. ÚS 285/2012 with further references.

712 I. ÚS 485/2010 with further references.

713 Koky and Others, no. 13624/03, 12 June 2012 and possibly also Žáková Malinová, no. 51493/07 (N.B.: The latter case was ultimately resolved by way of a friendly settlement leaving the question of exhaustion and effectiveness of domestic remedies open).
} 
the Convention were found in cases introduced by persons of Roma ethnic origin, in relation to domestic violence ${ }^{714}$ and as regards covert monitoring of telephone communication ${ }^{715}$.

A number of issues were identified from the viewpoint of the right to liberty under Article 5 and the right to a fair trial under Article 6. A high number of applications concerned protection of property.

The following overview may serve as an illustrative example of the issues addressed by the Convention organs and the effects of their decisions.

\subsection{Applications pointing to the situation of persons of Roma ethnic origin}

The Roma population of Slovakia is estimated at around 500,000 persons, or $9 \%$ of the total population. Many of the members of that community live in eastern Slovakia and they "remain caught in a spiral of exclusion and discrimination that affects their daily lives across a range of areas, from housing to education, employment and personal safety" ${ }^{\prime 16}$.

The number of applications lodged by persons of Roma ethnic origin has been relatively low, in particular in the 1990s, before human rights activists at both national and international level started defending their rights to a larger extent. Those applications resulted in most serious breaches of the Convention which the Court found in respect of Slovakia.

In the case of Mižigárová717 the applicant's husband was arrested on suspicion of theft. During his interrogation he was fatally shot in the abdomen with the police officer's service pistol. The investigation concluded that he had forcibly taken the gun from the officer and shot himself. The applicant's claims for damages were dismissed by the courts. The Court found a breach of Article 2 (right to life) under both its substantive and procedural limbs. It was not persuaded that the objective evidence was sufficiently strong in itself to suggest the existence of a racist motive. Subsequently the under-age daughter of Ms Mižigárová separately complained that she had been unable to obtain compensation for non-pecuniary damage on the ground that the State had failed to ensure respect for her and her late father's personal rights. On the basis of the Government's unilateral declaration acknowledging the applicant's status as a victim and offering to pay her a sum in compensation, the Court struck the application out of its list ${ }^{718}$.

In Koky and Others ${ }^{719}$ the Court established that an incident in a Roma settlement which involved a group of armed men who had forcibly invaded the applicants' home and resulted in injuries of two of them, exposed the applicants to treatment falling within the scope of Article 3 of the Convention (prohibition of ill-treatment). As the domestic authorities had failed to comply with their obligation to carry out an effective investigation, a breach of Article 3 under its procedural limb was found.

The case of K.H. and Others ${ }^{720}$ concerned the refusal to allow women of Roma ethnic origin to photocopy their own medical records when they suspected that their infertility might have resulted from a sterilisation procedure performed in hospitals during caesarean deliveries. The Court found a breach of Article 8 (respect for the applicants' private and

\footnotetext{
714 Kontrová, no. 7510/04, 31 May 2007; Hajduová, no. 2660/03, 30 November 2010.

715 Kvasnica, no. 72094/01, 9 June 2009 and Michalák, no. 30157/03, 8 February 2011.

716 Report by Thomas Hammarberg, Commissioner for Human Rights of the Council of Europe, following his visit to Slovakia, from 26 to 27 September 2011, CommDH(2011)42.

717 no. 74832/01, judgment of 14 December 2010.

718 Šarišská (dec.), no. 36768/09, 30 August 2011.

719 cited above.

720 no. 32881/04, judgment of 28 April 2009 and Resolution CM/ResDH(2012)56.
} 
family lives) and Article 6 (access to court). In its resolution closing its examination of the execution of the judgment the Committee of Ministers noted that the newly enacted legislation expressly empowers patients to make copies of medical records and that seven of the applicants had been able make photocopies of their files.

In three cases the Court addressed sterilisation of Roma women in public hospitals which had been carried out immediately after they had delivered children by Caesarean section ${ }^{721}$. As the sterilisation was not a life-saving intervention and since the applicants had not given their informed consent as required by the international standards, the Court found it incompatible with the requirement of respect for human freedom and dignity. The applicants had thereby been subjected to treatment contrary to Article 3 . In addition, there was a failure by Slovakia to comply with its positive obligation to secure the right to respect for the applicants' private and family life under Article 8 of the Convention, in particular due to the 'absence at the relevant time of safeguards giving special consideration to the reproductive health of the applicants as Roma women'. The Court noted that the practice of sterilisation of women without their prior informed consent affected vulnerable individuals from various ethnic groups. Despite the existence of a certain mindset, it could not be established that the doctors involved had acted in bad faith, that the applicants' sterilisation was a part of an organised policy, or that the hospital staff's conduct was intentionally racially motivated. At the same time, shortcomings in legislation and practice relating to sterilisations were liable to particularly affect members of the Roma community. Finally, the Court welcomed subsequent amendments to domestic law requiring prior informed consent and including a set of other guarantees to prevent similar situations from re-occurring.

The above examples point only to a part of the issues which members of Roma community encounter and which have been documented in detail in a number of documents at both national and international level. The individual applicants concerned obtained redress either under Article 41 of the Convention or as a result of the Government's above action. Any general measures to be adopted are to be considered in the context of the supervision of the execution of the judgments before the Committee of Ministers.

There are also examples of cases where persons of Roma origin were able to obtain adequate protection of their rights at domestic level.

In Lacko and Others ${ }^{722}$ two municipal councils adopted resolutions prohibiting persons of Roma origin from entering and settling in the respective municipalities. The resolutions were quashed following the intervention of the parliamentary committee for human rights and a public prosecutor. Subsequently, the Government made available a sum with a view to resolving the housing problem of the persons concerned. On that basis the Court concluded that the applicants had lost their status as victims within the meaning of Article 34 of the Convention.

Two recent judgments declaring discriminatory the placement of Roma pupils in separate classes and ordering the primary school concerned to cease such practices demonstrate that national courts are aware of the relevant international standards and able to provide redress to those concerned ${ }^{723}$.

${ }^{721}$ V.C., no. 18968/07, ECHR 2011 (extracts); N.B., no. 29518/10, 12 June 2012; and I.G. and Others, no. 15966/04, 13 November 2012.

722 no. 47237/99, decision of 2 July 2002.

723 Prešov District Court judgment 25C 133/10 of 5 December 2011, upheld by the Prešov Regional Court judgment 20Co 125/2012 - 20 Co 126/2012 of 30 October 2012. 
Policies have been in place with a view to combatting social exclusion in general and improving the situation of Roma in particular. It has been considered crucial that such policies remain a high priority in Slovakia's human rights agenda ${ }^{724}$.

\subsection{Right to liberty}

According to statistical information, after the right to a hearing within a reasonable time under Article 6, various aspects of the right to liberty and security under Article 5 have most frequently been found to have been violated in Slovakia. More precisely, violations of Article 5 have thus far been found in 39 cases.

Irrespective of these statistics, it is fair to say that complaints about a violation of this Article belong to the mainstream of complaints submitted to the Court in respect of Slovakia. At the same time, it is fair to say that most of the alleged and found violations have concerned detention in the criminal-law context and that complaints about other forms of deprivation of liberty are rather exceptional, having thus far mostly concerned persons considered to be of "unsound mind" in terms of Article $5 \S 1$ (e).

As to the latter category, only a handful of applications are worth of mention. They include the cases of Vodeničarov ${ }^{725}, T k_{a}$ ć $_{i k}{ }^{726}$ and Tám ${ }^{727}$. In the first of these cases, a breach of the "speediness" requirement under Article $5 \S 4$ of the Convention was found in respect of the proceedings for the examination of the lawfulness of the applicant's confinement with a view to examining his mental health in the context of criminal proceedings against him. In the latter two cases the breach of applicable time limits and other procedural flaws made the applicants' detention for the purpose of examination of their mental health contrary to the requirements of lawfulness under Article $5 \S 1$. Moreover, as in the case last mentioned the lawfulness of the deprivation of the applicant's liberty had ultimately not been determined at all, because he had meanwhile been released, a separate violation of Article 5 $\S 4$ of the Convention was found.

As to deprivation of liberty in the criminal-law context, the situations most frequently brought to the Court naturally concerned detention on remand.

On the structural level, a good deal of the Court's decision-making concerned the effectiveness and functional relationship of various domestic remedies for the purposes of Articles $35 \S 1$ and $5 \S 5$. In particular, an argument had been advanced by the Government that, before being entitled to bring an Article 5 case under the Convention, applicants should first assert their rights by way of an action for protection of personal integrity under Articles 11 et seq. of the Civil Code ${ }^{728}$ and a claim for damages under the State Liability Act $1969^{729}$. The matter was addressed by the Court as early as in the case of Pavletićc ${ }^{730}$ and its position has since then been reasserted a number of times. In particular, the Court found that, although some jurisprudential developments had taken place, by the relevant time it had not been established that the possibility of obtaining appropriate redress by making use of these remedies was sufficiently certain in practice and offered reasonable prospects of success as required by the relevant Convention case-law. In addition, examination of matters falling within the remit of the Code of Criminal Procedure was outside the jurisdiction of the civil courts and, in any event, these remedies were not aimed at and capable of redressing

\footnotetext{
${ }^{724}$ See supra note 28.

725 no. 24530/94, 21 December 2000.

726 no. 42472/98, 14 October 2003.

727 no. 50213/99, 22 June 2004.

728 Law no. 40/1964 Coll., as amended.

729 Law no. 58/1969 Coll.

730 no. 39359/98, 22 June 2004.
} 
the applicants' situation in its essence, that is to say to bring about an end to their continuing deprivation of liberty and rectification of the alleged shortcomings in the proceedings.

The argument was revived with reference to the new State Liability Act of $2003^{731}$, which specifically provides for compensation in respect of non-pecuniary damage. However, the use of that remedy had not been shown to be required by the Constitutional Court as a prerequisite for examination of an in individual complaint of a violation of Article 5 . As the Constitutional Court is the highest supreme authority for the protection of human rights and fundamental freedoms in Slovakia and as it is guided by the principle of subsidiarity, in the given circumstances the use of this "parallel" remedy was not found to be required for the purposes of Article $35 \S 1^{732}$.

The Court's pronouncements concerning the requirement of exhaustion of domestic remedies in connection with a claim for compensation under the State Liability Acts also had implications under Article $5 \S 5$. In cases of Osváthová ${ }^{733}$ and Michalko ${ }^{734}$ violations of the applicants' rights under Article $5 \S \S 3$ and 4 were found by the Court while similar complaints had been rejected as manifestly ill-founded by the Constitutional Court. As in these circumstanced neither before nor after the findings made by the Court have the applicants had an enforceable right to compensation at the national level, violations of Article $5 \S 5$ were also found. Conversely, no issue under Article $5 \S 5$ of the Convention was found in cases where a violation of a right under Article $5 \S \S 1-4$ had been found by the Constitutional Court but no just satisfaction in respect of non-pecuniary damage was awarded by it on grounds that were not contrary to the spirit of Article $5^{735}$.

Another structural problem resolved by the Court obtained in the line of cases following Kormos ${ }^{736}$, which concerned the practice at the national level under the 1961 Code of Criminal Procedure ${ }^{737}$ not to require a separate judicial decision to authorise a person's detention on remand after the filing of the bill of indictment beyond the point authorised in the pre-trial phase of the proceedings. This practice had gradually been condemned by the Constitutional Court and it was ultimately abolished under the provisions of the 2005 Code of Criminal Procedure ${ }^{738}$. In Kormoš, contrary to the Government's proposition, the Court endorsed the Constitutional Court's stance based on the premise that for a detention to be lawful it must always be authorised by a judicial decision, the mere filing of indictment being not enough. There is one more finding in the Court's judgement in this case that is worth of a particular mention, as regards the applicant's complaint under Article $5 \S 4$ concerning the alleged lack of a "speedy" review by the Constitutional Court of the lawfulness of his detention. In that respect, the Court reaffirmed and clarified its existing jurisprudence under which the guarantees of that provision extended to the proceedings before the Constitutional Court (of the Slovak Republic), albeit subject to certain distinction. The right to a "speedy" review was found to be applicable only as long as an applicant was still detained while the other guarantees concerning the efficiency of the review continued to apply even thereafter ${ }^{739}$.

\footnotetext{
731 Law no. 514/2003 Coll., as amended.

732 Michalák, cited above.

733 no. 15684/05, 21 December 2010.

734 cited above.

735 Loyka, no. 16502/09, 9 October 2012.

736 no. 46092/06, 8 November 2011.

737 Law no. 141/1961 Coll., as applicable at the relevant time.

738 Law no. 301/2005 Coll., as amended.

739 N.B.: As Mr Kormoš on his part had submitted the relevant part of his application more than six months after his release, it was rejected as being belated.
} 
Apart from that, the vast majority of the other Article 5 cases dealt with by the Court in respect of Slovakia may be described as technical, mainly dealing with questions of the length of detention under Article $5 \S 3$ and the length and other aspects of the procedure for the review of lawfulness of detention pending conviction under Article $5 \S 4$ of the Convention.

\subsection{Guarantees of a fair trial}

In the assessment of the impact of the Convention in the area governed by its Article 6, two major topical problems stand out.

The first concerns the right to a hearing within a reasonable time, the violation of which has been the most frequent Convention violation in Slovakia. Nevertheless, as already mentioned above, until the constitutional amendment no. 90/2001 Coll. that problem was without an effective remedy. Just as in respect of alleged violations of other Convention rights, the remedy provided for under that amendment was accepted as effective in the Convention terms also in respect of complaints about excessive length of proceedings $\mathrm{s}^{740}$.

However, some aspects the Constitutional Court's practice in dealing with complaints under the amended Article 127 of the Constitution in matters concerning length of proceedings were found not to be compatible with the Convention requirements.

In particular, it was the Constitutional Court's early practice, when dealing with the length of proceedings that had taken place before several instances and courts, not to examine the overall length of the proceedings but rather to examine separately their segments according to the courts involved ${ }^{741}$. This practice could thus for example result in rejecting the complaint as regards the first-instance court as belated and in examining solely the part of the proceedings before the court of appeal, which often time-wise represented a minor part of the proceedings. This practice was found to be putting in question the effectiveness of the new remedy in the Convention terms ${ }^{742}$, and it was subsequently refined by the Constitutional Court in that it would examine the overall length of the proceedings on the condition that the complainants formulate their constitutional complaints in a way allowing it such an examination, a condition that the Court found to be acceptable ${ }^{743}$.

Another feature of the Constitutional Court's practice in respect of complaints about length of proceedings, which was also found to pose Convention problems, concerns a requirement by the Constitutional Court that before a length-of-proceedings complaint may be admitted for examination by the Constitutional Court, it first has to have been raised in vain before the president of the court concerned in his or her capacity as an organ of the State Administration of the Judiciary. This requirement, combined with inconsistencies in the Constitutional Court's practice, again undermined the effectiveness of the by then no longer new domestic remedy ${ }^{744}$. The enforcement of the Court's judgments in this type of cases is in progress.

Lastly, developments in the Constitutional Court's practice as a result of the Court's intervention are also observable as regards alignment with the Convention standards of the

\footnotetext{
${ }^{740}$ Andrášik and Others (dec.), nos. 57984/00, 60237/00, 60242/00, 60679/00, 60680/00, 68563/01 and 60226/00, ECHR 2002 $\square$ IX.

741 Bako (dec.), no. 60227/00, 15 March 2005.

742 Jakub, no. 2015/02, § 47, 28 February 2006 and M. Bálintová, O (ne)účinnosti ústavnej st'ažnosti podl'a článku 127 ústavy vo vztáahu k prietáahom v konaní, Justičná revue 5 (2005).

743 Obluk v. Slovakia, no. 69484/01, § 60, 20 June 2006.

744 Ištván and Ištvánová v. Slovakia, no. 30189/07, 12 June 2012.
} 
level of just satisfaction awardable in respect of non-pecuniary damage due to excessive length of proceedings.

The second topical area concerns various aspects of the right of access to a court and applicability of the guarantees of Article 6 . Chronologically, violations of such guarantees were found in two early cases on account of the applicants' inability of having their convictions for a minor offence reviewed by a court. These findings resulted in the change of the relevant legislation ${ }^{745}$, already mentioned above ${ }^{746}$.

Another corrective intervention concerned the Constitutional Court's practice of not according the guarantees of Article 6 to proceedings on claims for damages joined by the victims of crimes to the criminal proceedings ${ }^{747}$, with modifications of the Constitutional Court's practice as a result.

The guarantees of access to a court under the Article in question were likewise violated in a case where a decision on the reimbursement of the applicant's costs as of a judicial enforcement officer had been taken by a senior court officer whose decision was not reviewable by a judge ${ }^{748}$.

Another particularly important development has taken place as regards the guarantees of a "tribunal established by law". In that respect, a violation of Article 6 was found on account of a decision by a district-court president acting in his administrative capacity to reassign a case to himself for judicial decision ${ }^{749}$.

However, as the relevant legislation had meanwhile been amended to align it to the Convention requirements, the enforcement of the judgments in the two cases last mentioned at the general level had become moot.

Lastly, at the jurisprudential level, the Convention has also been implemented in that, as a result of the Court's case-law ${ }^{750}$, the Constitutional Court has changed its practice ${ }^{751}$ of rejecting as premature constitutional complaints in matters that were subject to an appeal on points of law and as belated constitutional complaints in the same matter lodged after the appeal on points of law had been declared inadmissible.

The majority of other cases involving an allegation of a violation of Article 6 have been inadmissible as raising no more than questions falling within the doctrine of 'fourth instance'.

\subsection{Protection of property}

Slovakia's historical heritage and the transition to a market-oriented economy offered fertile soil for introducing complaints about a breach of the right under Article 1 of Protocol No. 1 to peaceful enjoyment of one's possessions. It may therefore seem surprising that such complaints have resulted only in twelve judgments on the merits, of which seven led to the finding of a breach of that provision.

The first major group of applications were in attempt to obtain redress for past wrongs, such as confiscation of property under the decrees of President Beneš issued after World War II or manifold forms of alienation of property under the communist regime. Several laws were

\footnotetext{
745 Article 83 of Law no. 372/1990 Coll., as amended (the Minor Offences Act).

746 Lauko and Kadubec, cited above.

747 Loveček and Others, no. 11301/03, 21 December 2010.

748 Mihal, no. 22006/07, 5 July 2011.

${ }^{749}$ DMD GROUP, a.s., no. 19334/03, 5 October 2010.

750 Stavebná spoločnost' TATRY Poprad, s.r.o., no. 7261/06, 3 May 2011.

751 Resolution CM/ResDH(2012)221.
} 
enacted within the former Czechoslovakia with a view to providing redress. Quite naturally, a number of those affected by the past wrongs found themselves excluded from the scope of such laws, e.g. because of the period covered, the property concerned, or the qualifying requirements, such as permanent residence on the territory of the respondent State and its citizenship ${ }^{752}$. It is in this context that the first and so far only application against Slovakia reached the Court's Grand Chamber. In the Kopecký judgment ${ }^{753}$ the Court reaffirmed that (i) deprivation of property is an instantaneous act which does not generate a continuing situation, (ii) the guarantees of Article 1 of Protocol No. 1 extend only to existing possessions, and (iii) those guarantees do not include the right to acquire ownership. The applicant failed in his claim for restitution of golden coins as he was unable, for reasons which could not be imputed to him, to meet the statutory requirement of indicating where the coins had been at the moment of the entry into force of the relevant law in 1991. In its judgment the Court concluded that the applicant's case concerned neither an existing possession nor an "asset" as, because of his failure to meet the statutory requirements he had no "legitimate expectation" of seeing his claim realised which would attract the guarantees of Article 1 of Protocol No. 1. It thereby confirmed that that provision imposed no particular obligations on the Contracting States as regards redress for infringements of property rights which had occurred prior to their accession to the Convention.

In a different case ${ }^{754}$ real property expropriated under the communist regime was restored to the applicants with final effect. The decision was later quashed with a view to bringing it in conformity with the subsequent finding of a court which was pertinent for the assessment of the claim. The Court found the applicants to have been deprived of their possessions contrary to Article 1 of Protocol No. 1 as the statutory requirements for reopening of the original proceedings had not been satisfied. This judgment developed the case-law by indicating that the Contracting States' freedom to determine the conditions under which they are willing to restore property alienated prior to their accession to the Convention does not absolve them from the obligation to comply with the relevant law. As the breach found stemmed from the application by national authorities of domestic law the Committee of Ministers held, with reference to the direct effect of the Convention and of the Court's caselaw at national level, that dissemination of the Court's judgment was a sufficient measure for the prevention of similar breaches in the future ${ }^{755}$.

The second major group of applications concerned denationalisation of property, business transactions several of which involved major State-owned or private companies, or the activities of "non-banking" entities which operated financial pyramid schemes. Cases in this category rarely reached the stage of the merits. The only case where a breach of Article 1 of Protocol No. 1 was found concerned the sale by a public auction of property which the applicant had acquired in the context of denationalisation of State property ${ }^{756}$. The Court held that by allowing the applicant's property to be bought by pre-emption in disregard of its actual value the domestic authorities failed to strike a "fair balance" between the demands of the public interest and the requirements of the protection of the applicant's rights. In its resolution the Committee of Ministers noted that the relevant law was amended to the effect that the lowest bid at a sale by auction in similar cases must be equal to the market value of the property ${ }^{757}$.

\footnotetext{
752 Brežný, no. 23131/93, Commission decision of 4 March 1996, DR 85, pp. 65-83.

753 no. 44912/98, §§ 35-61, ECHR 2004-IX.

754 Valová, Slezák and Slezák, no. 44925/98, 1 June 2004.

755 Resolution CM/ResDH(2009)69.

${ }^{756}$ Kanala, no. 57239/00, 10 July 2007.

${ }^{757}$ Resolution CM/ResDH(2010)62 of 3 June 2010.
} 
The third group of cases concern issues affecting larger groups of population and relate to the way in which national authorities regulated or regulate the use or transfer of property in pursuance of their economic and social policies. It is characterized by the highest ratio of applications declared admissible and the breaches of Article 1 of Protocol No. 1 found.

Several such applications were introduced by persons whose land had been put at the disposal of gardeners in garden colonies ${ }^{758}$. Law no. 64/1997 enacted in 1997 gave the gardeners the possibility of having the ownership transferred to them. The land owners claimed that the rent payable by gardeners and the compensation to which they were entitled for transfer of their land to gardeners were in disregard of its actual market value. The Court found the declared public interest not to be sufficiently broad to offer justification for the substantial difference between the real value of the applicants' land and its valuation under the law in force. In reaction, Slovakia amended the relevant statutory provisions, with effect from 1 April 2011, to ensure that both the rent and compensation for transfer be commensurate to the market value of the land. Where the land ownership had been transferred prior to that amendment, financial compensation corresponding to the difference between the compensation determined under the amended the law and the compensation already paid was foreseen ${ }^{759}$.

Several applications concern rent control, similarly to the issue which the Court addressed in its judgment Hutten-Czapska v. Poland. The proceedings on the merits are pending ${ }^{760}$.

\subsection{Other topical issues}

In connection with the moral renaissance and modernisation of the constitutional and legal system of Slovakia two cases are to be mentioned in which the heritage of the previous system was subject to the Court's review.

In the case of Ture ${ }^{761}$ the applicant was disqualified from holding certain posts in the public sector on account of negative security clearance indicating that he had been registered by the former State Security Agency ("ŠtB") as its collaborator. The applicant's challenge to his ŠtB registration was dismissed on the ground that he had failed to show that the registration was contrary to the ŠtB regulations. However, as those regulations were still classified, the applicant had been denied access to them. The Court recognised that there might be legitimate grounds to limit access to certain materials related to the operations of state security agencies. However, this consideration lost much of its validity in lustration proceedings because such proceedings were by their nature oriented towards the establishment of facts dating back to the communist era and they were not concerned with the current operations of the security services. Moreover, such proceedings inevitably depended on the examination of documents relating to the operations of the former communist security agencies. If the party concerned was denied access, his or her possibilities to contradict the security agency's version of the facts were severely curtailed, all the more so that it was typically the security agency itself that had the power to decide what materials should remain classified and for how long. In sum, the Court found a violation of Article 8 on account of the lack of a procedure by which the applicant could seek effective protection of his rights under that provision.

\footnotetext{
758 Urbárska Obec Trenčianske Biskupice, no. 74258/01, 27 November 2007 and also three other judgments of 3 November 2009: Jenisová, no. 58764/00; Šefčíková, no. 6284/02 and Salus, no. 28697/03.

759 Law no. 57/2011 Coll. of 8 February 2011.

760 E.g. Krahulec (dec.), no. 19294/07, 7 June 2011.

761 no. 57986/00, ECHR 2006-II (extracts).
} 
In the other case ${ }^{762}$, a violation of Article 8 was found on account of the impossibility in law of having cancelled the registration at the applicant's home address of a previous owner of her house who was unable to establish a new permanent residence. The applicant's case fell within the temporal scope of the old law of 1982 on registration of citizens' place of residence although a new legislation had been adopted in $1998^{763}$ to replace the old one, because after several postponements it took until 2004 for the new law to come into force.

In Labsi the Court found a breach of Articles 3, 13 (right to an effective remedy) and 34 (right of individual petition) on account of the applicant's expulsion to Algeria in disregard of an interim measure issue under Rule 39 of the Rules of Court. In the context of execution of the judgment the Government informed the Committee of Ministers of a declaration by the Ministry of the Interior undertaking to respect all interim measure which might be issued in the future ${ }^{764}$.

In a recent judgment a breach of Article 6 (right to a hearing by an impartial tribunal) was found in the context of disciplinary proceedings against the President of the Supreme Court ${ }^{765}$ . The Constitutional Court decided not to exclude any of the seven judges challenged by the parties holding that the disciplinary proceedings were within the exclusive jurisdiction of its plenary session and that excessive formalism might result in rendering them ineffective. The Court found no justification for the participation of two judges who had been excluded for lack of impartiality in earlier cases involving the applicant and in respect of whom objective doubts had not been dissipated. It held that appropriate form of redress would be the reopening of the proceedings by a tribunal complying with the requirement of impartiality.

The aforesaid case is of interest as it pointed to the possibility of proceedings before the Constitutional Court being thwarted in case of simultaneous challenges to several of its judges. Subsequently a similar situation occurred in proceedings related to the election and appointment of the Prosecutor General. With a view to resolving the issue, the Constitutional Court Act 1993 was amended in that it incorporates the 'doctrine of necessity' laid down in Bangalore Principles of Judicial Conduct. It is noteworthy that in the Harabin judgment the Court left open the question as to whether that doctrine is compatible with the guarantees of Article $6^{766}$.

\section{Legislative and jurisprudential implementation of the Court's case- law}

As regards legislative and jurisprudential implementation of the Court's case-law, in addition to the examples mentioned above, the following improvements warrant mentioning.

Under the statutory provisions on bail under the 1961 Code of Criminal Procedure detained persons could be released pending trial if a guarantee was provided on their behalf, if they gave a pledge of lawful conduct, or if they paid bail. However, by law, this possibility did not extend to persons charged with certain serious offences. The Constitutional Court found that this exclusion ran counter the guarantees under Article $5 \S 3$ of the Convention which were to prevail over the statutory text ${ }^{767}$.

Another concrete example of jurisprudential implementation of the Convention at the national level can be found in the interpretation given by the ordinary courts in some cases

\footnotetext{
762 Babylonová, no. 69146/01, ECHR 2006-VIII.

${ }^{763}$ Law no. 253/1998 Coll., as amended.

764 Secretariat of the Committee of Ministers, DH-DD(2012)1013.

765 Harabin, no. 58688/11, 20 November 2012.

766 Idem, § 139.

767 Michalko, no. 35377/05, 21 December 2010.
} 
to the scope of compensation awardable under the 1969 State Liability Act in respect of unlawful detention. That legislation had traditionally been interpreted and applied as not allowing for compensation to be awarded for non-pecuniary damage unless it was related to the deterioration of a person's health. However, in a judgment of 31 May 2007 the Supreme Court found that this legislation was to be interpreted in line with Article $5 \S 5$ of the Convention, which presupposed compensation for non-pecuniary damage, and which prevailed over the statutory text ${ }^{768}$.

At the legislative level, the "old" State Legality Act of 1969 had meanwhile been completely replaced by "new" State Liability Act of 2003. In the legislative process, the bill was accompanied by an introductory report and an explanatory report concluding that the old State Liability Act had been on the statute book since 1969 and that, owing to subsequent changes to the social system and the adoption of the Convention, there was a new understanding of the concept of State liability for damage which called for the introduction of new legislation. It was thus necessary to extend the existing perception of the right to damages from actual pecuniary damages to incorporate just satisfaction in respect of nonpecuniary damage. The purpose of the proposed new Act was, inter alia, to render the mechanism of compensation for damage caused by public authorities more effective and thereby reduce the number of cases in which claimants were obliged to seek redress before the Court ${ }^{769}$.

In another case ${ }^{770}$ a man was prevented from disclaiming his paternity by force of the principle of a res iudicata. His paternity had previously been determined by a judicial decision decades ago and there was no procedural avenue to have it denied at the material time despite new conclusive evidence consisting of the results of a DNA analysis. Following the Court's finding of a violation of the applicant's rights under Article 8 alone as well as in conjunction with Article 14, the law was amended in that proceedings may now be reopened if there is new evidence in connection with new scientific methods that were not available in the original proceedings ${ }^{771}$. This amendment accompanies a previous amendment allowing for the re-opening of judicial proceedings both in civil-law and criminal-law matters further to a judgment of the Court finding a violation of a party's Convention rights, such re-opening not being subject to the otherwise applicable objective time-limit ${ }^{772}$.

Furthermore, following the Hirst v. the United Kingdom (No. 2) ${ }^{773}$ judgment, upon a petition by the General Prosecutor the Constitutional Court declared unconstitutional the provisions of the National Council (Parliament) Election Act ${ }^{774}$ and the European Parliament Election Act ${ }^{775}$ which prevented persons serving a prison term from voting. Subsequently the two laws were amended in that they limit the scope of those who are not authorised to vote to persons serving a prison term for an offence punishable by ten years' imprisonment as a minimum. It is noteworthy that the Governmental draft amendment proposed that the restriction be removed in respect of all prisoners. The Parliament considered the above limitation to be compatible with the finding of the Constitutional Court.

\footnotetext{
768 a judgment on an appeal on points of law no. 4 Cdo 177/2005.

769 Kontrová v. Slovakia (dec.), no. 7510/04, 13 June 2006.

770 Paulík, no. 10699/05, ECHR 2006-XI (extracts).

771 Updated Action plan / action report: DH - DD(2011)1151.

772 Articles $228 \S 1$ (d) of the Code of Civil Procedure and $394 \S 4$ of the Code of Criminal Procedure.

773 Hirst v. the United Kingdom (no. 2) [GC], no. 74025/01, ECHR 2005-IX.

774 Law no. 333/2004 Coll., as amended.

775 Law no. 331/2003 Coll., as amended.
} 


\section{Dissemination and awareness}

As concluded by the authors Zuzana Koval'ová and Zuzana Vargová on the basis of a comprehensive survey ${ }^{776}$, international human rights law is included in the curriculum of most of the law schools in Slovakia, either as a compulsory or an optional subject, in Slovak or English. There has meanwhile also been a good deal of professional literature on the Convention in the Slovak language by judges of the Court, academics, as well as by the staff of the Office of the Agent for Representation of Slovakia before the Court ${ }^{777}$.

As regards training in the legal profession, as concluded by the authors of the abovementioned survey, there appears to be no compulsory training on the Convention. Optional training is occasionally offered by Judicial Academy, a body tasked with providing training of the judiciary and the Public Prosecution Service, and by the third sector. However, further professional education of lawyers on the Convention appears mainly to be a matter of selfeducation.

The Court's judgments concerning Slovakia and sometimes also other member States are published in the Slovak language and discussed in professional journals and magazines such as, for example, Justičná revue and Bulletin slovenskej advokácie.

Publication of the judgements against Slovakia in the former journal takes place as a general measure in the course of the enforcement of these judgments and it is accompanied by a transmission of these judgments with their translation into Slovak to the courts and other authorities concerned. The judgments concerning Slovakia are also published on the Internet site of the Ministry of Justice.

Furthermore, in addition to their core duties, the Office of the Agent for Representation of Slovakia before the Court play an active role in informing, promoting awareness, providing professional training, and co-ordinating various national activities linked to the Convention ${ }^{778}$

In practical terms, Convention case-law and knowledge is often drawn from various internet portals ${ }^{779}$, professional journals and literature, including those in the Czech Republic.

As to practicing lawyers, it is generally considered that only a relatively small specialised group of lawyers possess sufficient practical knowledge of the Convention. These are specialists on constitutional law or human-rights law and often practice in the third sector. In that respect, there are a number of non-governmental organisations promoting awareness and legislative and jurisprudential improvement and assisting victims of human rights violations in asserting their claims at national and international level ${ }^{780}$.

As observed by Zuzana Koval'ová and Zuzana Vargová, although the Convention is perceived as an international instrument prevailing over national law, lawyers in general prefer to base their arguments on the national legislation. The Convention is thus referred to rarely, and if

776 In The European Convention on Human Rights and Fundamental Freedoms in Central and Eastern Europe, edited by Leonard Hammer and Frank Emmert, 2011.

777 e.g. B. Repík: L'udské práva v súdnom konaní (cited above); V. Strážnická a kolektív: Medzinárodná a európska ochrana l'udských práv (2013); J. Svák: Advokát pred európskymi súdmi (2004); J. Svák: Rozsudky Vel'kej komory Európskeho súdu pre l'udské práva (2006); J. Svák: Ochrana l'udských práv (2006); J. Jankuv: Medzinárodné a európske mechanizmy ochrany ludských práv (2006); and M. Pirošíková: Komentár k vybraným článkom Dohovoru o ochrane l'udských práv a základných slobôd (2007).

778 see also M. Mierzewska: The Reception Process in Poland and Slovakia (cited above).

779 e.g. www.otvorenepravo.sk; www.najpravo.sk; www.jinepravo.blogsport.com.

780 Poradňa pre občianske a l'udské práva, Spoločnost' l'udí dobrej vôle, Liga za l'udské práva, Liga aktivistov pre l'udské práva, Občan, demokracia a zodpovednost', Pomoc obetiam násilia. 
so only as an additional supporting argument, mainly in claims for protection of personal integrity, in law of tort and as regards length of proceedings.

As to the public perception and awareness of the Convention, several reactions, in particular to judgments in cases attracting public attention and dividing the opinion, are indicative of a certain lack of understanding for the principles of equality and inalienability applicable to human rights. In this respect it is worthwhile to recall the adage that it is easy to grant his rights to a saint, but a sinner should be allowed to have the same rights'.

\section{Conclusions}

Ensuring respect for human rights and fundamental freedoms has been considered as one of the main criteria in assessing the quality of democracy in a given State ${ }^{781}$. From that point of view, the Convention is a particularly relevant indicator as it guarantees essential political and civil rights. At the same time, it does not allow for an assessment of the position in absolute terms due to its limited scope, subsidiary nature and a set of admissibility requirements which, if they are not complied with, prevent even serious cases from being examined on the merits.

The Convention may undoubtedly be said to have played, in respect of Slovakia, the role for which it was designed. Firstly, it has allowed for ensuring respect for the rights and freedoms guaranteed by it where an applicant has been unable to obtain redress at domestic level. Secondly, by its impact on domestic law and practice it has contributed to rendering the human rights protection in Slovakia compatible with the standards which are common for the Council of Europe member States. It has also contributed to improving the national mechanism of human rights protection.

The number of applications lodged against Slovakia over the last twenty years cannot be said to have overloaded the control mechanism. The number of cases where a breach was found does not appear excessive. The circumstances and nature of Convention breaches are not, but for a few exceptions, indicative of particularly serious shortcomings in domestic law and practice. The individual implementation of the Court's judgments in medially known, systemic as well as purely individual cases does not appear to have posed any particular problem.

As to future perspectives, in view of the ongoing reshaping of the legal system and the existing practice some fruit for thought may be found in the area of domestic remedies, their functional relationship and genuine effectiveness with a view to giving full effect to the object and purpose of the Convention and thereby allowing it to serve its proper subsidiary function.

It is highly probable that politicians, lawyers, historians, sociologists or journalists would assess the impact of the Convention system on Slovakia from different perspectives ${ }^{782}$ and that their conclusions would not coincide. We on our part dare to affirm that everybody would agree that effective protection of human rights in Slovakia would be difficult to conceive without the Convention.

781 V. Strážnická - Š. Šebesta: Človek a jeho práva; JUGA, Bratislava (1994), p. 212.

782 V. Berger: Jurisprudence de la Cour européenne des droits de l'Homme; DALLOZ (2011), p. 1. 


\title{
SLOVENIA
}

\author{
Jan Zobec ${ }^{*}$
}

Title missing

\section{Introduction}

Human rights, their respect and protection were, so to speak, laid into the cradle of the Republic of Slovenia as it was set up as the utmost and inevitable measure to protect human rights. Namely, the Basic Constitutional Charter on the Sovereignty and Independence of the Republic of Slovenia was adopted in light of the fact that the Socialist Federal Republic of Yugoslavia did not function as a state governed by law, and that within the common state human rights, national rights, and the rights of the republics and autonomous provinces were grossly violated. As determined in the Preamble to the Constitution, the fundamental national consensus was based upon two intertwined constitutional pillars: the first one is denoted by fundamental human rights and freedoms, while the second one is expressed in the centuries-long struggle for national liberation, which resulted in the establishment of the Slovene national identity and assertion of the Slovene statehood.

According to these historical facts, human rights are literally built into Slovene statehood. At first glance, the country and its citizens therefore seem to have no significant problems related to respect for, protection of, and ensuring human rights. In any case, the legal framework proves such an assumption - yet only to a certain degree. The Constitution guarantees protection against all forms of inequality and discrimination, in a much wider scope than it is guaranteed by international instruments, including the ECHR. ${ }^{783}$ The protection of the privacy of correspondence and other means of communication, guaranteed by Art. 37 of the Constitution, is much stronger than the protection afforded by international instruments (including Art. 8 of the ECHR). ${ }^{784}$ However, on the other hand, the Constitution has failed to explicitly provide for the right of persons charged with a criminal offence to examine witnesses against them or have them examined. ${ }^{785}$ Notwithstanding this fact, Slovenia made no reservations regarding the ECHR. When drafting the Slovene Constitution, the ECHR and the Strasbourg case law were taken into account ${ }^{786}$ and the outcome should be a modern constitution grounded on the entire existing body of constitutional and historical experience - the Slovene, the European, and even the global one (although in some respect the ECHR still provides a higher protection).

\footnotetext{
${ }^{783}$ See P. Jambrek, Slovensko ustavno sodišče pod okriljem evropskih standardov in mehanizmov za varovanje človekovih pravic [Slovenian Constitutional Court under the Protection of European Standards and Mechanisms for the Protection of Human Rights] in M. Pavčnik, A. Polajnar-Pavčnik, D. Wedam-Lukić (ed.): Temeljne pravice [Fundamental Rights], Cankarjeva Založba, Ljublajna 1997, p. 334; A. Mavčič in: R. Blackburn and J. Polakiewicz (eds.): Fundamental Rights in Europe, Oxford University Press, Oxford 2001, p. 781.

${ }^{784}$ See Constitutional Court (hereinafter also referred to as the CC) Decision No. U-I-40/12 (11 April 2013).

785 In case No. Up-518/03, the CC has therefore grounded its decision, in which the violation of the right to examine incriminating witnesses was established, directly on point $d$ of the third paragraph of Article 6 of the ECHR. Likewise, the CC decided in case No. Up-555/03, grounding its decision on Article 13 of the ECHR, which guarantees to everyone whose rights and freedoms, as set forth in this Convention, were violated the right to effective remedy before a national authority, notwithstanding that the violation has been committed by persons acting in an official capacity. Moreover, in case No. U-I-65/05 (in which the CC found that the Act on the Judicial Review of Administrative Acts was inconsistent with the Constitution) the $\mathrm{CC}$ applied the case law of the ECtHR, according to which the effective judicial protection of the right to a trial within a reasonable time is ensured only if it also comprises protection that affords that appropriate satisfaction be obtained by the person whose right was violated in already concluded proceedings.
}

786 See A. Mavčič, op. cit., pp. 782, 785. 
However, it is a relatively unpretentious task to draft and adopt constitutional and legal wording - as Justice Antonin Scalia once pointed out, every dictatorship has a better (and more modern, more comprehensive and more detailed) bill of rights than the US. ${ }^{787}$ It is not (only) a question of how the idea of human rights is worded (as a Slovene saying goes, paper endures all), but rather of how a legal text is brought to its life - or, in other words, how the judiciary plays its role. Namely, a legal text alone is just a bare skeleton - and it is up to the judiciary to put muscles on it and hence carry out the law. Since human rights are designed as principles (rather than rules) and since most of them (actually their holders) are in constant conflicts (e.g. privacy v. freedom of expression), their genuine contents and scope have been determined through case law - it has developed incrementally, step by step, case by case. The law in books could not survive without the factual substratum delivered by case law; namely, the law emanates from facts and ever-changing life experience - as $\mathrm{O}$. W. Holmes once said: "The life of the law has not been logic: it has been experience." ${ }^{188}$ Even all the great codifications are nothing but an abstracted response to life, a doctrinal restatement of the preexistent judicial wisdom (which is later analysed, classified, and verified by doctrine - the rest is tossed on the scrap-heap of legal history). If law is to be effective, it must never be separated from the foundation from which it arises, from the substance which it regulates and to which it always returns, therefore it must keep the connection to its organic essence, which is nothing but life itself in its full scope. Real-life practice, subject to judicial decision-making, always outsmarts theory. No legal scholar can envisage in advance the inexhaustible and infinite variety "invented" daily by reallife practice.

Therefore, the jurisprudence of the ECtHR (together with national constitutional and supreme courts as its partners) has an immense importance for the life of human rights in Europe and hence for the development of the normative integration in Europe. Regarding the latter, the active and dynamic approach is to be considered -in two ways: as a promise and as a threat. Setting the minimum standards in ensuring human rights and their respect all over Europe, the ECtHR has the central position and role not only in enforcing but also in enhancing the integration of the Old continent on the basis of human rights - thus incrementally building the common European constitutional order. ${ }^{789}$

On the other hand, excessive activism in this respect could have (and actually has) a counter-effect. Hence, a dialogue between the ECtHR and national courts should run two ways. In the continuous search for the scope and the extent of the margin of appreciation the Strasbourg court, as the central European creator of the minimal (but constantly growing) common denominator of human rights, should keep its attention on the evolution of the national courts' case law and thereby on the evolution of the European human rights consensus. ${ }^{790}$ The Strasbourg jurisprudence should therefore reflect and at the same time incrementally develop this consensus - and in doing so, the Court is

787 A. Scalia's closing address at the National Lawyers Convention (The Federalist Society), Washington, 17 November 2012.

788 See Page 1 of his famous book The Common Law - accessible at:

http://www.gutenberg.org/catalog/world/readfile?fk_files=1449046\&pageno=7

789 The ECtHR should be the tribunal whose "pronouncements are decisions concerning minimum standards, irrespective of how the violations happened in Iceland or in Azerbaijan" (the Case of Hutten-Czapska v. Poland, dated 19 June 2006, partly concurring, partly dissenting opinion of judge B. M. Zupančič).

790 That could be perceived through the impact of the consensus on the scope of the margin of appreciation. Or, in other words, as Spielmann observed, "the broader the consensus surrounding an issue, the narrower the margin of appreciation available to the government" (D. Spielmann, Allowing the Right Margin the European Court of Human Rights and the National Margin of Appreciation Doctrine: Waiver or Subsidiarity of European Review?, CELS Working Paper Series, Cambridge 2012, p. 18). Does it mean that the enlargement of the Council of Europe has resulted in a lowering of the probability of finding the inter-states' consensus and thus in an increase of the scope of the margin of appreciation? (W. Sadurski, Partnering with Strasbourg: Constitutionalisation of the European Court of Human Rights, the Accession of Central and East European States to the Council of Europe, and the Idea of Pilot Judgements, Human Rights Law Review, Vol.9 (2009), No. 3, pp. 400-401). 
setting its foot on the political (better policy) ground, taking advantage of the flexible (misty and vague) doctrine of the margin of appreciation. ${ }^{791}$ Since the ECHR has been commonly accepted as a living instrument, it should, through the ECtHR case law, be (and actually is) in constant interaction with the fluid nature of the real life of human rights in particular states and across Europe. The preamble to the ECHR stipulates that the aim of the Council of Europe is to achieve greater unity between its Members, and that one of the methods by which the aim is to be pursued is, in particular, (not just maintenance but also) further realisation of human rights and fundamental freedoms. Therefore, the ECHR, as we know it nowadays (evolved in line with the progress in the legal, social, and scientific fields), is not the same as it was 50 years ago (when the old contracting parties ratified it) and even not the same as it was in the early 90s (when young democracies joined the "club").

Namely, should we agree with Joseph Raz (and there is no reason why we shouldn't) that a right of one person is not a duty on another - it is actually the ground of a duty, and that "there is no closed list of duties which correspond to the right" and that "[a] change of circumstances may lead to the creation of new duties based on the old right", 792 then the allegory of human rights as a prism would become more evident. ${ }^{793}$ Moreover, Raz continues that "one may know of the existence of a right and of the reasons for it without knowing who is bound by duties based on it or what precisely these duties are." ${ }^{\prime 94}$ And the mentioned (prismatic) allegory complements his statement - namely the expansion of the ECtHR influx of cases goes hand in hand with its incremental and case-based approach and consecutively the expansion of the scope of human rights. We are facing a selfaccelerating vicious circle, which could imply (euphemistically) that the ECtHR is a victim of its own success. As "over time, new aspects of fundamental rights may be discerned or 'discovered', even if they are still hidden from our present powers of perception," 795 and the new interests are covered by respective human rights, the litigation battle field is given a new dimension. If an interest, wrapped in the human right('s rhetoric), overweighed the other competing (yet ordinary) interest, such a concept would hence lead to the strategic litigation in which parties "argue that their interests should be regarded as elements of fundamental rights"796 - what inevitably leads to an increased influx of cases. In other words: the greater the number of human rights disputes before national courts (provoked by Strasbourg's judicial activism in inventing new hues of the respective human right), the greater the caseload of the ECtHR: and consequently, the greater the number of judgements, the greater the possibility of contradictions between them.

In that respect, it serves the Strasbourg Court right for the increased caseload and its chronic backlog. Therefore, less euphemistically but more truly, the ECtHR is a victim of its own non-success - regarding the re-establishment of the proper balance between permissible judicial activism grounded on the need to take account of a changing social climate, ${ }^{797}$ and judicial self-restraint -

\footnotetext{
791 The case of Hirst v. the United Kingdom (No. 2), dated 6 October 2005, reflects the sensitivity of the question of the margin of appreciation - if the balance between the Strasbourg system and national systems has not been struck. The Court stated that "the United Kingdom is not alone among Convention countries in depriving convicted prisoners of the right to vote" and even if "the number of such States does not exceed thirteen [...] this cannot in itself be determinative of the issue." It is well known how the story continued (para. 81).

792 J. Raz, The Morality of Freedom, Oxford University Press, Oxford 1986, p.171.

793 See J. Gerards, The Prism of Fundamental Rights, European Constitutional Law Review, Vol.8 (2012), No. 2, pp. 173-202.

794 J. Raz, op. cit., p. 184; see also pp. 170-72, 184-86 (discussing the relationship between rights and duties).

795 J. Gerards, op. cit., p. 178. Typically the ECtHR in the Case of Christine Goodwin v. the United Kingdom (11 July 2002), where the Court did not change its position because its previous case law was wrong in principle but because it felt social attitudes had changed in the meantime (see G. Sadlier, The Success of the ECHR, Cork Online Law Review, Vol. 7 (2007), p. 70). The recent judgement in the case of Gross v. Switzerland (14 May 2013) also proves this assumption.

796 See J. Gerards, op. cit., p. 180.

797 The inherent dynamic nature of the Convention has been expressed in the judgement Tyrer v. the United
} 
reflecting prohibition of "judicial legislation". 798 If the ECtHR is much more restricted on the protection of the Convention's core standards, there will probably be less influx into its docket - and it will be highly esteemed throughout Europe as the moral authority and the bulwark of civil liberties, upholding the ECHR's standards in time of need. And above all, such an approach of the ECtHR will enhance the protection of human rights. However, nowadays we are facing a paradox process - a growing anomie and the decay of normative (and ethical) integration ${ }^{799}$ that go hand in hand with the overflow of human rights - indeed human rights as a means (just an effective practical semantic tool for achieving certain tangible and at times even selfish interests) - far from being the aim or the end per se. A provocative question could therefore be raised: Is an exponential increase in the number of cases before the ECtHR and the overflow of its judgements a sign of an increase of the general anomie leading to the decline of the Convention system?

\section{Historical aspects of the accession to the ECHR:}

\subsection{A brief overview of the Constitutional Order:}

On 25 June 1991 Slovenia became an independent and sovereign state. The Constitutional Court of the former federal unit of former Yugoslavia, which had been established in 1963 (on 5 June 1963 the first President and eight judges of the then Constitutional Court had been appointed), thus became the constitutional court of the newly independent State. The process of transition to a contemporary democratic political social order was thereby launched, based on the respect for human rights and the principle of a State governed by the rule of law. A turning point in this process was the adoption of the Constitution of the Republic of Slovenia, on 23 December 1991. The Constitution introduced the principle of the separation of powers. With its implementation, the Constitutional Court of the Republic of Slovenia acquired important new powers as well as the position of the highest body of the judicial power for the protection of constitutionality, legality, human rights, and fundamental freedoms.

The constitutional position of the independent and autonomous body exercising constitutional review was detailed by the Constitutional Court Act (hereinafter also referred to as the CCA), which came into force on 2 April 1994. The amendments to the Constitutional Court Act entered into force on 15 July 2007. The Constitutional Court Act determines the procedure for deciding in cases falling under the jurisdiction of the Constitutional Court. In addition, the Constitutional Court Act regulates the procedures for the election of Constitutional Court judges and its President, as well as their position in more detail. Stemming from the principled position that in relation to other State bodies the Constitutional Court is an independent and autonomous State body, the Act determined that funds for its work be provided by the National Assembly of the Republic of Slovenia on the Court's

Kingdom (25 April 1978). The Court considered the ECHR as a "living instrument which [...] must be interpreted in the light of present-day conditions" (para. 31).

798 The ECtHR should bear in mind that the ECHR was designed to be and still remains a minimum standard for protecting human rights, rather than an unbending rule to which states must aspire, regardless of the differences in social conditions or the democratic choices of citizens (G. Sadlier, op. cit., p. 72). See for example the separate opinion of Judge Martens in the case of Fischer v. Austria (26 April 1995): "No provision of the Convention compels the Court to decide in this way on a strict case-by-case basis. This self-imposed restriction may have been a wise policy when the Court began its career, but it is no longer appropriate. Case law that is developed on a strict case-by-case basis necessarily leads to uncertainty as to both the exact purport of each judgment and the precise contents of the Court's doctrine." Quoted in Robert Harmsen, The European Convention on Human Rights after Enlargement, International Journal of Human Rights, Vol. 5 (2001), p. 18 at 33.

799 Judge B. M. Zupančič has been constantly pointing out the process of normative and social disintegration, the general decay of common values, and the universal anomie (see Tembatsu, Ljubljana 2012, see also Dignity, Anomy...and the Future of Human Rights [Dostojanstvo, anomija...in prihodnost človekovih pravic], Revus, Vol. 10 , November 2009, p. 25). 
proposal, and that the Court alone decides on their expenditure. The Act vested the Court with the authority to regulate its internal organisation and work by its own acts.

Most of the Constitutional Court's powers are explicitly determined in the Constitution; however, they may also be determined by statute. The Constitutional Court exercises extensive jurisdiction intended to ensure the effective protection of constitutionality (and legality) and for the prevention of violations of human rights and fundamental freedoms. According to the Constitution, The Constitutional Court decides on the conformity of laws and other regulations with the Constitution, on the conformity of executive regulations and local community regulations with statutes, on constitutional complaints stemming from the violation of human rights and fundamental freedoms by individual acts (in principle only if all legal remedies have been exhausted), on the unconstitutionality of the acts and activities of political parties, on appeals against National Assembly decisions on the confirmation of National Assembly Deputies' mandates, on impeachment against the President of the Republic, the Prime Minister and Ministers, and on the conformity of a treaty with the Constitution in the process of ratifying such treaty. The latter is performed on the proposal of the President of the Republic, the Government or a third of the deputies of the National Assembly.

\subsection{The Status of the ECHR in the domestic legal order:}

\subsubsection{The relationship between the domestic and the international legal order}

The relationship between the domestic and the international legal order is regulated in Article 8 of the Constitution, designed to guarantee the respect for international obligations. It provides: 1) that laws and regulations must comply with generally accepted principles of international law and with treaties that are binding on Slovenia, and 2) that ratified and published treaties shall be applied directly. Under the Constitution the principles of international law and international instruments have a special position within the hierarchy of legal acts. To ensure the implementation of international obligations and to prevent breaches of such obligations, the international instruments are given a higher position than statutory laws. The hierarchy of legal acts is regulated in Article 153 of the Constitution. The second paragraph provides that laws must be in conformity with generally accepted principles of international law and with valid treaties ratified by the National Assembly, whereas regulations and other general legal acts must also be in conformity with other ratified treaties.

Articles 8 and 153 are supplemented (and strengthened) by the provisions which vest the $C C$ with the authority on one side to a priori review the conformity of an international agreement with the Constitution - thus preventing the legislature to introduce unconstitutional legal norms into the domestic legal order (otherwise, in the case of delaying the review of international agreements to a time following their ratification, the state would be in breach of an international obligation if it were to find that such agreements are inconsistent with the Constitution - namely, according to Article 27 of the Vienna Convention on the Law of Treaties, a party may not invoke the provisions of its internal law as justification for its failure to perform a treaty), and on the other side with the authority to decide on the conformity of laws and other regulations with ratified treaties and with the general principles of international law - thus placing international instruments in a position above the (national statutory) laws.

So far so good - the system would function coherently if there was a mandatory a priori review of the constitutionality of international treaties. Namely, the CC is always empowered to review a statute even if, in terms of its substance, this is an individual legal act. Therefore the act on ratification is subject to constitutional review. The $\mathrm{CC}$ has explicated that by incorporating the provisions of an international agreement into the act on its ratification; these provisions are, however, not given the legal nature of statutory provisions. Similarly, only because the act on ratification incorporates an international agreement, the provisions of this act are not given the legal nature of an international agreement. Thus, the act on ratification and the international agreement, 
whose adoption is confirmed by the former, are not one and the same legal act. Also concerning their legal nature, these two legal acts are not identical. Therefore, the CC has the jurisdiction to perform a posteriori review of the constitutionality of the act on the ratification of an international agreement pursuant to that provision of the Constitution which confers on the Court the jurisdiction to decide on the consistency of statutes with the Constitution. With the ratification, the state (Slovenia) binds itself in terms of international law by stating that it considers the international treaty to be binding on it. Speaking in terms of international law, an obligation has been created. Hence it follows that during the decision-making by the $\mathrm{CC}$, it is completely impossible to prevent the binding effect of the international obligation contracted by the Republic of Slovenia by abrogating the act on ratification. In view of international law, abrogating this act would mean breaking the international agreement, except in the case of the abrogation with an appropriate postponing effect which would allow the termination of an agreement. ${ }^{800}$.

A further problem may arise from the fact that the National Assembly (legislature) is not the only body empowered to ratify international treaties. The Foreign Affairs Act (hereinafter referred to as the FAA) ${ }^{801}$ vests the Government with the power to ratify international treaties that regulate matters which, according to the internal legal order, fall within the competence of the Government, treaties that are concluded with the aim of implementing concluded international treaties, further, treaties that are concluded by ministries and deal with the exchange of experience and maintenance of contacts with ministries in other countries, treaties regulating issues associated with diplomatic and consular relations, and those which involve the implementation of assumed obligations or adopted decisions on international cooperation of the Republic of Slovenia in the field of defence or internal affairs.

Whereas Article 8 of the Constitution does not answer the question of whether the international treaties ratified by the Government rank lower in the hierarchy of legal acts, the second par. of Article 153 of the Constitution is more exact: In relation to the laws, priority is given only to those international treaties which have been ratified by the National Assembly. The international treaties ratified by the Government are therefore hierarchically below the laws. ${ }^{802}$ Nevertheless, the international obligation of the state remains - whether the respective treaty has been inconsistent with the laws or not. According to the generally accepted international law principle pacta sunt servanda, international law imposes the duty to perform the international obligations irrespective of the question which state body ratified the treaty and irrespective of the party's internal law hierarchy of legal acts. Hence the question arises, how the problem of an inconsistency of an international treaty ratified by the Government with a law should be resolved. Namely, the (abovementioned) a priori review of the international treaty is designed only for the treaties ratified by the National Assembly. Moreover, in the internal hierarchy of legal acts executive regulations must be in conformity not only with the Constitution but also with the laws (the third paragraph of Article 153 of the Constitution) and the CC has the jurisdiction to safeguard this constitutional demand (third indent of the first paragraph of Article 160 of the Constitution).

However, that does not mean that international treaties ratified by the Government must be in conformity with the laws. It follows from CC Order No. U-I-376/02 (issued on 24 March 2005) that a review of a regulation (a decree of the Government) by which a treaty was ratified cannot, even indirectly, justify the jurisdiction of the Constitutional Court to review the legality of a treaty. Such implies that a statute and a treaty ratified by a decree may be inconsistent, but the Constitutional Court does not have jurisdiction to review such inconsistency. The Constitutional Court will review an inconsistency between a statute and a treaty ratified by a decree of the Government only if the inconsistency was a violation of Article 2 of the Constitution (the principle of a state governed by the rule of law). In such case, the question of the legality of the decree on ratification (for which the

800 See Order No. U-I-197/97 (issued on 21 May 1998).

${ }^{801}$ Zakon o zunanjih zadevah (Official Gazette RS, No. 113/03 - official consolidated text, 78/08, and 108/09).

802 That has been confirmed by the CC (Decision No. U-I-147/94, dated 30 November 1995). 
Constitutional Court has jurisdiction according to the third indent of the first paragraph of Article 160of the Constitution) could be raised. The question of the constitutionality of a decree is also raised in the case of the unconstitutionality of one of the provisions of a treaty. In such case, the decree would violate the Constitution, as it would incorporate an unconstitutional legal norm into the internal legal order. This could lead to the conclusion that international treaties ratified by the Government are ranked on the same hierarchical level as the laws. ${ }^{803}$ However, Slovene jurisprudence has not yet advanced an opinion on whether courts are bound by "illegal" regulations (decrees of the Government) by which a treaty was ratified. Since such regulation ranks as law, the answer would probably be positive.

Since the conflict between the duties stemming from the pacta sunt servanda principle and the respect for the constitutional hierarchy of legal acts cannot be fully prevented and reconciled in all respects, the only way to resolve the entanglement lies in the withdrawal of either the conflicting legal provision or the contentious treaty. Article 87 of the FAA therefore provides the following: If the provisions of an international treaty do not conform to the law or other regulations, the Government shall initiate a procedure for amending the law or other regulation, or for amending or terminating the treaty concerned. However, slight priority is given to international law. Namely, pending the decision of the competent body, the international treaty shall be applied (the second paragraph. of Article 87 of the FAA).

In principle, the Slovene legal order could be assessed as a dualistic approach regarding the relationship between domestic and international law - yet, not in its full dimension. A monistic approach could be perceived in the second paragraph of Article 8 of the Constitution, providing that ratified and published treaties shall be applied directly - as a matter of principle requiring no translation into the national legal order. Ultimately, all depends on the (practical) question of whether the international treaty provides adequate rules by which given rights may be enjoyed or imposed duties may be enforced (self-executing norms) - it is up to national courts to decide on that question. 804

\subsubsection{The Status of the ECHR in the National Legal Order}

Slovenia passed the law for the ratification of the ECHR on 31 May 1994 and the ECHR became binding for Slovenia on 28 June 1994, when it formally ratified the Convention in Strasbourg by depositing the appropriate instruments with the Secretary General of the Council of Europe. It is worth mentioning that Slovenia 1) made no reservation and 2) recognised the competence of the European Commission and the jurisdiction of the ECtHR for an indeterminate period. ${ }^{805}$ According to the second paragraph of Article 8 of the Constitution, the Convention was transferred into the Slovene legal (and constitutional) order directly - and all Slovene laws and other regulations must conform to the Convention within its integral and original wording. Hence not only courts (including the CC) but also the legislature and the executive branch of government must respect the Convention and ensure that national legal acts comply with it. Moreover, the provisions of the Convention, relating to human rights, are given constitutional status - and thus (together with the case law of the ECtHR) complement national constitutional provisions. ${ }^{806}$ The provision of the fifth

\footnotetext{
803 That contravenes the viewpoint expressed in the decision No.U-I-147/94 dated 30 November 1995.

${ }^{804}$ See U. Umek in: L. Šturm (ed.), Komentar Ustave Republike Slovenije, dopolnitev - A [Commentary on the Constitution of the Republic of Slovenia, the Supplement-A], Fakulteta za državne in evropske študije, Ljubljana 2011, p. 133.

805 See P. Jambrek, op. cit., pp. 338-339, 348. The author is pointing out his assumption that a more detailed review of Slovene legislation would certainly reveal some inconsistencies with the Convention. The fact that Slovenia has made no reservation, does not, in his opinion, exactly demonstrate a high standard of respect for human rights - rather it expresses a certain degree of lack of self-assurance, perhaps even hypocrisy, or an attempt to set up a satisfactory international image, irrespective of the state's capacity to implement the obligations undertaken by the ratification of the Convention in everyday legal practice.
} 
paragraph of Article 15 of the Constitution requires that no human right or fundamental freedom regulated by legal acts in force in Slovenia may be restricted on the grounds that this Constitution does not recognise that right or freedom or recognises it to a lesser extent (the principle of the highest level of protection).

Such leads to the conclusion that provisions of the Convention regulating human rights have in this regard even a supra-constitutional rank - namely they have priority over constitutional provisions if they guarantee a higher level of protection than the Constitution. Therefore, it has (incrementally) become a regular and common practice before Slovene courts that parties and court judgements refer to the Convention and the case law of the ECtHR. Hence, there is no doubt about the direct applicability of the provisions of the Convention - all the more so since they have been given a more precise, clear and defined meaning through the case law of the ECtHR. After all, the Convention, like any other international treaty, is binding upon all States Parties to it. They must therefore respect Article 1, which stipulates that the High Contracting Parties shall secure the rights and freedoms enshrined in the Convention and later on decoded by the case law of the ECtHR.

\subsection{Mechanisms of implementation and coordination:}

\subsubsection{Overview (The role of the ECtHR):}

As most of the Convention's provisions are broad, vague and flexible, and their true meaning is yet to be discovered and determined through case law, the jurisprudence of the ECtHR is regarded as a (semi) formal legal source. Namely, what is the scope of a state's submission to the jurisdiction of the Strasbourg Court? Is it limited only to perform its duty to pay a just satisfaction to the injured party or does it comprehend the respect of the legal reasoning given in the judgement, its holding (ruling), rationes decidendi. A further question may arise as to which cases are to be considered - only cases in which the respective state has been a party to proceedings or all relevant cases, irrespective of the parties.

The pragmatic approach (from the perspective of avoiding being condemned for violating human rights) would probably favour the latter. The same result would be achieved by the Conventionfriendly approach - grounded in Article 1, obliging the States to secure the rights and freedoms defined in the Convention. Since most of the Convention's human rights norms are of a general nature, the main role of the ECtHR is to elucidate and clarify their meaning. Or, as G. Sadlier explicated, "[i]t seems appropriate that to avoid manifest injustice and absurdity, the Court should treat the Convention as a living instrument, rather than one set immovably in the political and social climate of the 1950s." ${ }^{187}$ Accordingly, should the Court treat the Convention as a "living instrument", is there any reason why national courts should treat it differently? Moreover, a State's submission to the international jurisdiction and its obligation to secure the rights and freedoms stipulated in the Convention inevitably include the respect for the concept of the ECHR as a living instrument, or, in other words, the submission to ECHR-law means not only the submission to the bare wording of the provisions of the ECHR, but also to ECtHR case law, what ultimately (despite the first paragraph of Article 46, which stipulates that a judgement has an effect merely in the relation between the applicant and the state - i.e. inter partes) leads to a de facto erga omnes effect of the Court's decisions. ${ }^{808}$

\footnotetext{
806 A. Mavčič, op. cit., p. 785

807 G. Sadlier, op. cit., p. 69. The author refers to the golden rule, which suggests that in interpreting fundamental rights instruments ".... the letter killeth but the spirit giveth life".

${ }^{808}$ See B. M. Zupančič, The Owl of Minerva, Essays on Human Rights, Eleven International Publishing, Utrecht 2008, pp. 351-392; U. Umek, op. cit., p. 141. See also L. Wildhaber, The European Court of Human Rights, 1998-2006: History, Achievements, Reform, N. P. Engel, Kehl 2006, p. 184.
} 
In this regard judgements have the effect of precedents and as such, due to the power of their arguments, they are binding upon the states's bodies - not only those of the respective (affected) state, but also of all the states joined together in the Council of Europe. Moreover, it appears logical. Namely, since (as mentioned before) most of the provisions of the Convention regulating human rights are of a general nature and their linguistic wording is far from being an exhaustive description of the substance of the respective right, of its scope and extent, it is inevitable that their true (and particular) meaning should yet be construed and decoded through case law. If any legal provisions provoke a high tension between "law in books and law in action", it is the ones that regulate human rights. And the ECtHR has the ultimate word on the substance of Convention rights, an inherent part of the Convention system, which was established not only to provide just satisfaction for the impaired but also (and most of all) to elucidate the meaning of the broad, flexible and vague wording of the provisions stipulating Convention human rights and freedoms. I dare say that the latter has priority over the former (thus being merely a side product of the ultimate role of the ECtHR). ${ }^{809}$

The CC clearly stated its opinion on the matter in its Decision No. U-I-65/05, dated 22 September 2005. In this case the Constitutional Court had to consider (at that time) the most recent case law of the ECtHR according to which the effective judicial protection of the right to a trial within a reasonable time is ensured only if it also comprises protection that affords the person whose right was violated in already concluded proceedings the possibility to obtain appropriate satisfaction. The CC ruled that in view of the case law of the ECtHR, the fourth paragraph of Article 15 of the Constitution, pursuant to which the judicial protection of human rights and the right to obtain redress for the violation of such rights are guaranteed, must, in the spirit of the ECHR, be interpreted in a manner such that it requires that, in the framework of the judicial protection of the right to a trial without undue delay, the possibility of claiming just satisfaction be ensured also in cases in which a violation already ceased to exist. Concerning such, the criteria of the ECtHR for assessing whether a reasonable time for a trial has been exceeded must be taken into consideration.

Therefore, the decision-making process of a national CC (which decides human rights cases) should be two-fold: at the first and broader stage the Court treats itself as the ECtHR and takes a position on how the Strasbourg tribunal would decide the case - if it was on its worktable (thus considering the ECHR and the Strasbourg case law). If the Court finds that there has been no breach of ECHR human rights, the process proceeds to the second stage. The Court then examines whether the challenged decision has abridged the complainant's right guaranteed by the Constitution. The Constitutional Court of the Republic of Slovenia adopted the point of view that in the case that the ECHR and the Constitution guarantee an equal protection of a particular human right, its decision is based only upon the Constitution - what is clearly defined in the reasoning. After all, the CC is primarily the guardian of the Constitution and constitutional provisions should therefore be the upper premise of its decision-making - the ECHR thus remains just the back-up upper premise, an arrow left in the CC's quiver. ${ }^{810}$ Nevertheless, the CC usually gives content to a particular constitutional provision determining a certain human right by employing the jurisprudence of the ECtHR (mostly as additional comparative arguments strengthening its own arguments).

\footnotetext{
${ }^{809}$ Former Constitutional Court Judge C. Ribičič has written (Človekove pravice in ustavna demokracija [Human Rights and Constitutional Democracy], Študentska založba, Ljubljana 2010, pp. 115-116): “The comparison between the Constitution and the ECHR demonstrates that the list of constitutional rights seems to be broader, more complete, more detailed and more demanding than the list of Convention rights. However, this advantage is reduced to a considerable extent and in many a view even disappears if regard is paid to the fact that the ECHR is not merely its bare wording, but rather everything what the ECtHR has read from the Convention and has added to it in each of its more than ten thousand decisions on the merits." (trans. J. Z.) 810 The third upper premise is the Charter of Fundamental Rights of the European Union - due to the fact that the State passed a part of its sovereignty to the EU; it is not the upper premise in the shadow, but in EU cases it is rather the primary one.
} 
The binding nature of the Strasbourg Court judgements does not refer only to the legislature, but also to national courts. They are obliged to interpret provisions of national laws in accordance with the ECHR. This duty clearly arises from Article 1 of the Convention, which stipulates that States shall secure to everyone within their jurisdiction the rights and freedoms defined in the ECHR. In a democratic state governed by the rule of law this obligation could only be met if all branches of government are bound by demands arising from the Convention.

\subsubsection{Judiciary}

However, Article 125 of the Constitution provides that judges shall be bound by the Constitution and laws - not mentioning ratified treaties and general principles of international law. Therefore, the question of a conflict between the law and a Convention right may arise. How should such a conflict before the (ordinary) courts be resolved? Shall the court give priority to the international treaty or the law (that is in conflict with the former)? Regarding human rights provisions with their inherent broad and flexible nature, and thus being subject to construction through interpretation, the conflict will probably focus on the interpretation of the respective right provided by the ECtHR (the ultimate interpreter of the Convention and the rights enshrined therein) on one side and a particular provision of a certain law on the other. The controversy would increase if the CC made an interpretation of the human right that would not reach the standard developed through ECtHR case law. Should priority be given to the interpretation of the CC or to the one provided by the ECtHR? Stemming from the aforementioned position of the ECtHR and the power of its case law (de facto erga omnes effect) in connection with Article 8 of the Constitution (providing that ratified and published international treaties shall be applied directly), and in connection with the principle of the highest level of protection of human rights (as stipulated in the fifth paragraph of Article 15of the Constitution) the answer should be in favour of the Convention and its interpretation given by the body which has the last word in this respect. Accordingly, even if the courts are not expressly (and directly) bound by the ratified treaties and the general principles of international law, they are bound indirectly and implicitly by international instruments regulating human rights through the constitutional principle of the highest protection of human rights (the fifth paragraph of Article 15 of the Constitution).

\subsubsection{NGOs}

The role of NGOs in Slovenia should not be underestimated, however, they have limited legal possibilities to appear and participate in proceedings before the courts and other state bodies. ${ }^{811}$ They are not granted standing in proceedings before the $\mathrm{CC}^{;} ; 12$ although some of them (The Peace Institute and The Legal-informational Centre) have participated as third-party interveners before the ECtHR in the "erased persons" case (Kuric and others v. Slovenia - Ap. No. 26828/06). A few of them should be exposed - those, that are more known to the public mostly due to their activities and/or media support.

First, the Legal-informational Centre for $\mathbf{N G O s}^{813}$ (a non-governmental organisation established in 1997 by the Peace Institute, Amnesty International Slovenia, the Association for Development of Preventive and Voluntary Work, the Regional Centre for Environment for Central and Eastern Europe - REC Slovenia, and ALCEDO), whose mission is to provide legal support to individuals, vulnerable groups, and NGOs in the promotion and protection of their rights and to strengthen their position in society. ${ }^{814}$

\footnotetext{
811 Nevertheless, they may submit applications and writs, explicating their statements, views and tenets in the issue at stake. However, the courts have no obligation to express a standpoint in this respect.

812 Except when they protect human rights of their own membership.

813 Pravno-informacijski center nevladnih organizacij - PIC.

814 See its website: http://www.pic.si/.
} 
The goal of Amnesty International is well known - quite so the scope of its activities. The Slovene Section has become a notable discussion partner in the field of human rights. Its activities could be divided into four prongs: upholding and advancing the general awareness of the importance of the respect for human rights, efforts towards systemic changes that would improve standards of protection of human rights, carrying out campaigns and human rights activism, and education in human rights (through workshops at schools for students and teachers). Amnesty International explicitly lays stress upon the way of financing (subscription and donations). ${ }^{815}$

Academic Lawyers' Association ${ }^{816}$ is a leading independent and non-partisan association of Slovenian lawyers and law students, aiming to promote the values of freedom, democracy, and rule of law within Slovenian and European society. Association fulfils its mission by organizing annual legal conferences and monthly debate panels, called IUS Caffès, on latest Slovenian and European legal issues, featuring distinguished Slovenian and foreign experts.

The Association of constitutional law ${ }^{817}$ is dealing with the theory of the constitutional law, hence contributing to its development and connecting constitutional law with the current social conditions, striving after enhancing and furthering the principles of constitutionality and institutions of the constitutional democracy. The Association organizes conferences, symposiums and lectures and provides its membership with the information concerning the theory and the practice of constitutional law.

The Peace Institute ${ }^{818}$ is mainly a policy research NGO, which was established through grants from the Open Society Institute. Its aim is comparable to those of Amnesty International - however, it is more structured in thematic fields and, as regards human rights, focused on monitoring intolerance, migration and asylum policies, gay and lesbian studies, racism and xenophobia, conflict resolution in communities, and education programs for the prevention of discrimination. The goal of the Institute is not only to adopt a critical stance towards events in society but also to actively intervene in these events, to link academic research and reflection with practical educational and strategic advisory activities in various fields of public policy and public action in general. ${ }^{819}$ The Institute is declared as a non-governmental and non-profit organisation; however the sources of funding are not mentioned. Therefore one can only presume that its funding consists mainly of membership/participation fees and donations (and not of the governmental financial support).

In any case, from a general point of view, activities of NGOs, such as promoting human rights, raising common awareness and education, conducting research in the field of human rights law, carrying out analyses of national and Strasbourg case law, and providing legal aid for the aggrieved and impaired, should be appreciated as notable and valuable. By performing such activities, NGOs serve their purpose well and significantly complement the efforts of institutions which are legally designed as guardians of human rights. Numerous successful projects prove this. ${ }^{820}$

Nevertheless, there are some minor and sometimes overlooked drawbacks that should be mentioned. Some of them stem from the fact that Slovenia is a small country with a small population. Especially smaller Slovene NGOs (with up to five employees) lack sustainable funding and the capacity to gain financial strength (often due to the lack of human resources or the lack of expert knowledge on fundraising). ${ }^{821}$ Therefore, only a few of them have the relevant financial, organizational and intellectual capacity to carry out their goals. Another shortcoming is the lack of

\footnotetext{
${ }^{815}$ See its website: http://www.amnesty.si/j7/kdo-smo/kdo-smo.html.

${ }^{816}$ Akademsko društvo Pravnik. See its website: http://www.adp.si/

817 Društvo za ustavno pravo Slovenije. See its website: http://www.ustava.si/DUPS/o-drustvu

818 Mirovni Inštitut.

${ }^{819}$ See its website: http://www.mirovni-institut.si/Publikacija/All/en/knjizna_zbirka/Raziskovalna-porocila.

${ }^{820}$ See for instance the website of the Peace Institute: http://www.mirovni-institut.si/Projekt/All/en/.

821 See A. Bister, Development NGOs in Slovenia, Trialog - Development NGOs in the enlarged EU, September 2005, p. 7.
} 
pluralism among NGOs (partly as a consequence of the previously stated reason) and hence a deficiency in the positive competition. Some of the NOGs have become the prey of politics (taken over by one of the political blocks or initially established by its sympathizers or even fans and activists or certain interest groups and networks), promoting human rights mostly (or even exclusively) in such a way and in cases which are in favour of their affiliation (following the agenda of their ideological/political sponsors sitting in the background), while restraining their activities in cases when political and ideological opponents might gain some profit. It seems to be just one of the reflections of the general and deep ideological and political split in Slovene society (the so-called right, or better, "spring" ideological/political option v. the so-called left political option, i.e. the "old regime" option) - consequently lacking considerable and genuine civil society. Therefore the NGOs influenced (and controlled) by the ruling "old regime" ideological/political option (which has been and still is in power throughout the still on-going "transitional period") are mostly silent about the mass and systematic violations of human rights during the communist era (e.g. genocide and mass murders in the after-war period, abuse of the judiciary, killings at the "Slovene Berlin wall" ${ }^{822}$ ) as well as attacks on the Catholic Church and its members due to their religious mission and religious belief.

\subsubsection{The Human Rights Ombudsperson}

has a special position in the Slovene legal order. It could be deemed as a semi-state body placed somewhere between the formal state structure and civil society. It has been established in order to protect human rights and fundamental freedoms against the abuses of state authorities, local selfgovernment authorities and bearers of public authority. The Ombudsperson is thus an informal feature of the protection of human rights in vertical relations between individuals on one side and state and local authorities on the other. It is not vested with authoritative decision-making power; its power rests on the cooperation with the public and on the power of its reasoning.

Although it is an institution formed according to the classical model of the national parliamentary ombudsperson, adopted by the majority of Western European countries, the Slovene Ombudsperson is vested with a special competence, unique in comparison with the competences of any other similar body in Europe. According to the Constitutional Court Act, the Ombudsman is one of the socalled privileged applicants entitled to initiate the procedure before the CC for the review of the constitutionality of laws or the legality of regulations or general acts issued for the exercise of public authority. The Ombudsperson is authorized to submit such a request if he or she deems that a law, regulation or general act issued for the exercise of public authority inadmissibly interferes with human rights or fundamental freedoms (the fifth indent of the first paragraph of Article 23a of the CCA). This unique authority is complemented by the provision granting the Ombudsperson the right to lodge a constitutional complaint in connection with an individual case that he or she is dealing with (the second paragraph of Article 50 of the CCA). So far the Ombudsperson has lodged 23 requests for the review of the constitutionality and two constitutional complaints. By providing the Ombudsperson with a real and active tool for the effective protection of human rights, thus enabling him or her to act proactively, the law has given the Ombudsperson a chance to become an active and significant partner in the dialogue with the CC.

822 For example: With the exception of the Academic Lawyers' Association (even though not being exclusively focused on the human rights issues), none of the NGOs objected to the nomination of a person who had pronounced the last death sentence in the Slovene legal history (in addition, at the time of delivery of the first instance judgement the convict had been found partial insane, later even absolute insane and sent to psychiatric treatment) and who had been involved (as an investigation judge) in the killings of refugees from Central and Eastern Europe on the ex-Yugoslav border with Italy in the 1980s to the position of the President of the Supreme Court of the Republic of Slovenia (in November 2010). 


\section{The European Court's Case law in relation to the State}

\subsection{Overview}

The relationship between Slovenia and the ECtHR is most prominently expressed through the dialogue between the $\mathrm{CC}$ and the Strasbourg Court. The Slovene CC began referring to the ECHR even before it became formally binding for Slovenia. ${ }^{823}$ In Decision No. U-I-98/91 (dated 10 December 1992) when considering the upper premise (the right of appeal) the CC clearly referred to the Convention. The CC highlighted that the purpose of the constitutionally guaranteed right to a legal remedy is not only to allow an individual to lodge an appeal or other legal remedy but, primarily, to defend and protect his or her legal interests by presenting such a legal remedy. Additionally it argued that such an interpretation also follows "[...] from the European Convention on Human Rights, whose Article 13 ensures to everyone an effective legal remedy in case of violation of the rights and freedoms specified therein." It then continued: "It is true that Slovenia has not yet signed and ratified the European Convention, but considering its desire to join the Council of Europe, it will necessarily have to do so, for which reason it is appropriate for our legislation to be adjusted to the criteria of the European Convention on Human Rights as soon as possible." A step further was taken in Decision No. U-I-48/92 (11 February 1993) in which the CC "[...] based its decision on the [ECtHR] which, when considering mandatory membership in the Association of Doctors of Belgium, took up the position that the Chamber of Doctors is an institution of public law exercising public control over medical practice." Therefore "[...] the Chamber cannot be considered to be an 'association' in the sense of Article 11 of the European Convention on Human Rights." 824 In other cases, however, the CC declined the application of the ECHR, as it had not been ratified yet. ${ }^{825}$

After the ratification of the ECHR the relationship between the ECtHR and the State can be divided into two periods. The first denotes the transition, a period of indulgence for the young democracies, the new members of the Council of Europe. Some authors even state that the ECtHR was distinctly lenient towards Slovenia during that period. ${ }^{826}$ Namely, in the period up to the moment when the landmark judgement in the case of Lukenda v. Slovenia (6 October 2005) was handed down Slovenia was found to have violated the Convention in just two cases. This changed after the year 2005. The number of established violations of human rights mounted to a number higher than two hundred till the year 2013.

The question may arise as to why Slovenia turned from a state that was rarely condemned for violating human rights into a state featuring among those who have been found as the most recurrent violators. At first glance one could conclude that the general situation in Slovenia regarding the respect for human rights worsened in the last ten years. However, if other circumstances (first of all the aforementioned deference of the ECtHR, supported by a considerably lower level of awareness of the parties and their attorneys of the Conventional system for the protection of human rights), are taken into consideration, it appears that there had rather been a change towards an improved detection of (and an increased sensitivity for) human rights violations, than a change in the general approach towards the respect for human rights (the latter has probably even increased in the last ten years). This assumption is confirmed by the structure of the ECtHR cases against Slovenia, as the vast majority of these consists of violations of the right to a trial within a reasonable time - thus revealing a deep, complex, and systemic problem of the functioning of the rule of law in Slovenia. In the course of time lawyers became increasingly aware of the importance of the ECtHR and its case law as well as the fact that they could not be successful without a comprehensive knowledge of the

\footnotetext{
823 See A. Mavčič, op. cit., pp. 782-783.

824 The CC referred to the case of Le Compte, Van Leuven and De Meyere v. Belgium (23 June 1981).

825 Cf. Order No. U-I-2/92 (10 June 1993), Decision and Order No. U-I-46/92 (9 December 1993).

826 See C. Ribičič, Evropsko pravo človekovih pravic [European Law on Human Rights], Pravna fakulteta Univerze v Ljublajni, Ljubljana 2007, p. 178.
} 
ECHR and above all the Strasbourg case law. ${ }^{827}$ Figuratively speaking, once there were only blue skies above the CC, nowadays, however, these blue skies may at times be partly covered by a cloud named the ECtHR.

\subsection{Selected examples}

While Slovenia is one of the states infamous for their convictions for violating the right to a trial within a reasonable time, the range of noteworthy judgements in relation to Slovenia covers a wide spectrum of ECHR rights. Those cases may be divided into groups according to different criteria: some entail examples of severe violations, where the Court considered the basics (Rehbock, Matko, Šilih), others reflect problems arising from the dissolution of former Yugoslavia (Kurić and others, Kovačić and others), there are also some pilot judgements (Kurić, Lukenda), ${ }^{828}$ and some typical examples of the Court's leniency (Tričković). In the cases of Flisar, Suhadolc, Berdajs, Marguč, Milenović and Mesesnel, all of them dealing with proceedings conducted pursuant to the Minor Offences Act, the right to be heard in proceedings was at stake, while the final group consists of cases concerning the right of respect for and safeguarding of the mutual enjoyment by parent and child of each other's company as an essential element of "family life" (Eberhard and M., Z., K., V., X., and S.I.).

The judgement in the case of Rehbock v. Slovenia (28 November 2000) was the first astonishing judgement against Slovenia - a case concerning inhuman or degrading treatment by the police. It was characteristic from several aspects. First, it revealed the gravity (actually brutality) of police violence in the case at issue; second (and more interesting from a juridical point of view), since the facts of the dispute have not been the subject of any determination by a national court, the ECtHR entered the slippery territory of fact finding (see p. 70-76); third, the applications to be released introduced by the applicant were dismissed after 23 days and thus were not examined "speedily" as required by the fourth paragraph of Article 5 of the ECHR; fourth, the monitoring of the applicant's correspondence during detention amounted to an interference with his rights under the first paragraph of Article 8 of the ECHR - namely there were no compelling reasons for the monitoring of the relevant correspondence, whose confidentiality it was important to respect; and finally, the case demonstrated the unpreparedness of the Slovene government to meet the necessary requirements in the proceedings before the Strasbourg Court: the Government's objection that the applicant had failed to exhaust the domestic remedies that were at his disposal (i.e. to seek compensation under Article 26 of the Constitution before the CC by means of a constitutional complaint), was not raised, even though it could have been, when the admissibility of the application was being considered by the Commission - there was therefore no estoppel.

The case of Matko v. Slovenia (2 November 2006) belongs to the same group; likewise dealing with police violence (the case involved the same police unit as was involved in the Rehbock case - the Slovenj Gradec Police). In this case the police had not only inflicted ill-treatment on the aggrieved applicant, but the authorities had also failed to conduct an effective investigation into his allegations, which was contrary to Article 3 of the ECHR. ${ }^{829} \mathrm{In}$ addition, the case demonstrated the alliance between the Strasbourg Court and national constitutional courts. ${ }^{830}$ In that respect the ECtHR

\footnotetext{
827 Ibid., p. 179.

${ }^{828}$ A pilot judgement was also delivered in the case of Ališić and others (6 November 2012) - however, the case has been referred to the Grand Chamber and is still pending at the time of writing.

829 The investigation, led exclusively by the police, failed to produce any tangible results, not even the names of the alleged perpetrators. In such circumstances the applicant could not be required to institute a subsidiary prosecution, which would have had the same objective as a criminal complaint and had no prospect of success. Nor was the applicant obliged to institute civil proceedings for compensation (para. 95).

${ }^{830}$ As W. Sadurski and other scholars have pointed out, collaboration of the ECtHR with national courts against the national executive branch of power or the legislature may be a crucial element of a right-supportive strategy (W. Sadurski, op. cit., p. 421).
} 
welcomed CC Decision No. Up-555/03, Up-827/04 (6 July 2006), in which it held that the Constitution should be interpreted so as to include also a right to an independent investigation of the circumstances of an incident where a person was allegedly subject to torture or inhuman or degrading treatment by the police (the procedural limb of the right determined in Article 3 of the ECHR). The ECtHR nevertheless reiterated that the investigation, in order to be effective, must be capable of leading to the identification and, if appropriate, punishment of those responsible. Both lessons from Strasbourg (as well as the aforementioned CC Decision No. Up-555/03, Up-827/04) stimulated the Government to propose appropriate amendments of the Police Act and the Code of Criminal Procedure regarding the supervision of police activities.

In addition, some cases concerning degrading treatment in the Ljubljana prison (due to conditions in which the applicants were detained) belong to this group (the cases of Štrucl and others v. Slovenia, and Mandić and Jović v. Slovenia - both judgements of 20 October 2011). The ECtHR did not consider that there had existed a structural problem consisting of "a practice that is incompatible with the Convention" nationwide. However, it emphasized the need to take steps to reduce the number of prisoners in the Ljubljana prison and by doing so to put an end to the existing situation, which appeared to disregard the dignity of a considerable number of detainees held therein, and to prevent future violations of Article 3 of the ECHR on that account. ${ }^{831}$

The case of Šilih v. Slovenia (9 April 2009) belongs to the same "fundamental" group. Namely it concerns a violation of Article 2 of the ECHR in its procedural limb. The Government objected (inter alia) that the applicants had failed to exhaust domestic remedies, as the civil proceedings were still pending, moreover (after the termination of the criminal and civil proceedings) the applicants would also be able to lodge a civil claim for compensation against the State on the basis of the alleged violation of their rights in the proceedings. In addition, the Government argued that the applicants had failed to avail themselves of the remedies in respect of the complaints of undue delay. The ECtHR, however dismissed those objections, upholding the Chamber's finding that "[...] the length-ofproceedings remedies were insufficient as it was not merely the length of the proceedings which was in issue, but the question whether in the circumstances of the case seen as a whole the State could be said to have complied with its procedural requirements under Article 2 of the Convention." ${ }^{332}$ The Grand Chamber also upheld the Chamber's observation, that the Government's objection regarding the on-going civil proceedings had been closely linked to the substance of the applicants' complaint under the procedural aspect of Article 2 of the ECHR. Its examination should therefore be joined to the merits of the case.

And what were the merits of the case? The condition of the applicants' son started to deteriorate significantly while he was in a hospital. His death was possibly related to the medical treatment he received. The applicants alleged that his death was a result of negligence on the part of the doctor. Since the public prosecutor refused to initiate criminal proceedings against the doctor, the applicants themselves instituted criminal proceedings. Their first request to open a criminal investigation had been dismissed; however after they had obtained a new medical opinion, the investigation was reopened - almost two years after their initial request. These proceedings then continued for more than four years and were finally terminated by the interlocutory-proceedings panel's decision. The applicants had recourse to civil proceedings in which they were entitled to an adversarial trial enabling them to establish the responsibility of the doctors or hospital concerned and to obtain any appropriate civil redress. However, those proceedings were stayed for three years and seven months pending the outcome of the criminal proceedings which the applicants were pursuing concurrently. Moreover, even in the two years before they were officially stayed, the civil proceedings were in fact already at a standstill.

${ }^{831}$ Following the classification applied by P. Leach and his co-authors, these judgements would fall into the third tier, i.e. other judgements addressing systemic issues (P. Leach, H. Hardman, S. Stephenson, B. K. Blitz, Responding to Systemic Human Rights Violations, Intersentia, Antwerp, Oxford, Portland 2010, pp. 26-27). 832 The case of Šilih v. Slovenia, para. 169. 
The Court stressed that even though the stay of civil proceedings in itself was not unreasonable, that stay did not release the Slovene authorities from their obligation to examine the case promptly. Hence the civil court before which the applicants' case was pending remained responsible for the conduct of the civil proceedings and ought therefore to have weighed the advantages of a continued stay against the requirement of promptness when deciding whether or not to resume the proceedings. At the time of delivery of the Grand Chamber's judgement there was a constitutional complaint regarding the applicants' civil law case pending before the CC. ${ }^{833}$ In the light of all these circumstances, the ECtHR considered that the domestic authorities failed to deal with the applicants' claim arising out of their son's death with the level of diligence required by Article 2 of the Convention. Namely, the State is required to set an effective independent judicial system so that the cause of death of patients in the care of the medical profession, whether in the public or the private sector, can be determined and those responsible made accountable. A prompt response by the authorities is vital in maintaining public confidence in their adherence to the rule of law and in preventing any appearance of collusion in or tolerance of unlawful acts. On the other hand, knowledge of the facts and of possible errors committed in the course of medical care are essential to remedy the potential deficiencies and prevent similar errors. The prompt examination of such cases is therefore important for the safety of users of all health services. ${ }^{834}$

There is another reason why the case of Šilih $v$. Slovenia is important, i.e. the ECtHR has clearly established the tenet of the division of the procedural obligation under Article 2 of the ECHR from its substantive aspect. The death of the applicants' son occurred only a little more than a year before the entry into force of the ECHR in respect of Slovenia, while, with the exception of the preliminary investigation, all the criminal and civil proceedings were initiated and conducted after that date. Therefore, the ECtHR's jurisdiction ratione temporis in respect of the procedural complaints was met.

The case of Tričković v. Slovenia (judgement delivered on 12 June 2001) is an example of the ECtHR's leniency towards Slovenia. The applicant complained about the length of the proceedings before the CC. After the ECtHR determined the applicability of the first paragraph of Article 6 of the Convention to proceedings before a Constitutional Court, ${ }^{835}$ it found that a reasonable time within the meaning of the first paragraph of Article 6 had not been exceeded. The ECtHR paid attention to the role of the CC as guardian of the Constitution which makes it particularly necessary for a CC to sometimes take into account considerations other than the mere chronological order in which cases are entered on the list, such as the nature of the case and its importance in political and social terms. It argued: "Regard being had to the importance of the decision of the Constitutional Court in the present case, the impact of which reached far beyond the individual application, the latter principle is of special pertinence here. Therefore, the Court finds that the Constitutional Court did not act unreasonably in holding lengthy discussions and consulting other bodies in order to obtain a comprehensive view of the different legal issues." 836

\footnotetext{
833 The CC delivered Decision No. Up-2443/08 on 7 October 2009, explicitly upholding the ECtHR judgement in finding the failure to investigate the death. The CC decided that the court deprived the complainants of their right to participate in the procedure for taking evidence. Thereby, it violated their right determined in Article 22 of the Constitution.

834 However, in the subsequent case of Volk v. Slovenia (13 December 2012), the ECtHR found that the authorities investigated the applicant's son's death (during his stay in prison) with the diligence and promptness required under the procedural limb of Article 2 of the ECHR. It also noted that there is no indication that the applicant had not been sufficiently involved in the investigation.

835 The ECtHR stated "[...] that under its settled case-law the relevant test in determining whether proceedings come within the scope of Article $6 \S 1$, even if they are conducted before a Constitutional Court, is whether their outcome is decisive for the determination of the applicant's civil rights and obligations." (para. 39) As the proceedings complained of concerned the applicant's claim for an advance on his military pension, which was of a pecuniary nature and hence indisputably concerned a civil right within the meaning of the first paragraph of Article 6 of the ECHR, the aforementioned test was met.

${ }^{836}$ The case of Tričković v. Slovenia, paras. 65-66.
} 
The judgement delivered in the case of Lukenda v. Slovenia (6 October 2005) is well-known for several reasons. Although it is just one case in a series of judgements establishing state violations of the right to a trial within a reasonable time, it was the first pilot judgement against Slovenia. ${ }^{837} \mathrm{After}$ a precise analysis of the existing Slovene system of legal remedies, the ECtHR concluded that such remedies (or the aggregate remedies), as the Government pleaded that they were designed for the purpose of expediting judicial proceedings and/or claiming compensation, cannot amount to an effective legal remedy. The ECtHR noted that in view of the persistent backlog in Slovene courts in general, it is clear that the length of judicial proceedings remained a major problem in Slovenia; furthermore, it took into consideration the fact that there were approximately 500 length-ofproceedings cases against Slovenia pending before the ECtHR. Hence the violation of the applicant's right emerged as an expression of a systemic problem that resulted from inadequate legislation and inefficiency in the administration of justice.

The pilot judgement (commanding appropriate legal measures and administrative practices to be undertaken to secure the right to a trial within a reasonable time) had triggered comprehensive responds - legislative and administrative (the so called Lukenda Project). ${ }^{838}$ As the "Pinto" Act in Italy, the "Lukenda" Act (the Act Regulating the Protection of the Right to a Trial without Undue Delay, Official Gazette RS, No. 67/12 - official consolidated text) regulating the right to a trial without undue delay was passed in Slovenia and several administrative measures aimed at the elimination of backlogs were undertaken. The Lukenda judgement marked the end of the period of the ECtHR's indulgence towards Slovenia. It laid the foundation for the dialog and alliance between Strasbourg and the $\mathrm{CC}$ regarding the protection of the right to a trial within a reasonable time.

Interestingly, just two weeks before the Lukenda judgement was delivered, the CC handed down Decision No. U-I-65/05 (22 September 2005) on the constitutionality of the Act on the Judicial Review of Administrative Acts. The CC reviewed whether affected persons were ensured effective judicial protection of the right to a trial without undue delay under the first paragraph of Article 23 of the Constitution if the proceedings in which this right had been violated had already been concluded. It decided that the challenged Act was not consistent with the Constitution. In the reasoning, it inter alia set forth that "[i]n order to satisfy the guarantees of Art. 5 and Art. 15.4 of the Constitution and the requirements of the ECHR, the legislature will have to comprehensively regulate the protection of the right to a trial without undue delay [...]. In establishing the system of the protection of the right to a trial without undue delay, the legislature will have to pay special attention to ensure that it does not additionally (over)burden courts or, to put it differently, that the new legal remedy for the protection of the right to a trial within a reasonable time does not cause additional prolongation of court proceedings."

The cooperation and alliance between both courts were implemented in the CC Case No. U-I-207/08, Up-2168/08 (18 March 2010). As the legislature did not regulate the status of the injured parties who claimed just satisfaction before national courts due to a violation of the right to a trial within a reasonable time in the same manner as it regulated the status of persons who claimed just satisfaction before an international court in Article 25 of the Act Regulating the Protection of the Right to a Trial without Undue Delay (the so called "Lukenda" Act), the CC found that the legislature had violated the fourth paragraph of Article 15 of the Constitution in connection with the first paragraph of Article 23 of the Constitution (the right to a trial without undue delay).

The next pilot judgement was delivered in the case of Kurić and others v. Slovenia (26 June 2012) concerning the "erasure" of non-citizens from the register of permanent residents. The "erased" were citizens of other republics of former Yugoslavia who resided in Slovenia at the time of its

\footnotetext{
${ }^{837}$ For a comprehensive review of the problem of the excessive length of court proceedings in Slovenia see $\mathrm{P}$. Leach and others, op. cit., pp. 76-96, 101-104.

838 Joint state project for the elimination of court backlogs: the Lukenda project, operational plan, Ljubljana, 12 December 2005.
} 
independence, but who (for different reasons) did not obtain Slovene citizenship. The case demonstrates the dialogue between the Strasbourg Court and the Slovene CC, as the former relied on previous decisions of the latter (CC Decisions No. U-I-284/94 of 4 February 1999 and No. U-I246/02 of 3 April 2003). ${ }^{839}$ The year-long story in fact commenced in 1992, when the "erasure", creating a widespread human-rights concern, occurred. For the majority of "erased" persons this situation lasted for nearly 20 years - in spite of the CC's leading decisions (which were themselves not complied with for more than a decade - until 24 July 2010, when the amended Legal Status Act, regulating the status of the "erased" ex tunc and ex nunc in compliance with CC Decision No. U-I246/02, entered into force). However, apart from CC Decision No. U-II-1/10 of 10 June 2010 (by which the CC did not allow a referendum to be held on the abovementioned amended Legal Status Act) the ECtHR, opined that the acknowledgment of the human rights violations and the issuance of (both ex nunc and ex tunc) permanent residence permits did not constitute "appropriate and sufficient" redress at the national level. So far none of the "erased" have been awarded compensation for the damage sustained by a final and binding judgement (although several sets of proceedings were still pending). ${ }^{840}$

The ECtHR thus concluded that (despite the efforts made after the CC decisions of 1999 and 2003, as well as with the enactment of the amended Legal Status Act) the Slovene authorities failed to remedy comprehensively and with the requisite promptness the blanket nature of the "erasure" and its grave consequences for the "erased". In addition to a violation of the right to respect for private and/or family life, the ECtHR found that the remedies available to the applicants were not "adequate" and "effective" in order to redress such violation - accordingly, there had also been a violation of the right to an effective remedy. Finally, the Court found that there had been a violation of the prohibition of inequality (in conjunction with Article 8 of the ECHR). ${ }^{841}$

With regard to all facts the Court adopted a pilot-judgment (indicating that Slovene authorities should within one year, set up an ad hoc domestic compensation scheme). ${ }^{842}$ Namely, the ECtHR found that the facts of the case disclosed the existence, within the Slovene legal order, of a shortcoming as a consequence of which the whole category of the "erased" were still denied compensation for the infringement of their fundamental rights. Although only a few similar applications lodged by "erased" persons were currently pending before the ECtHR, in the context of systemic, structural or similar violations the potential inflow of future cases was also an important consideration in terms of preventing the accumulation of such repetitive cases on the Court's docket.

The case of Kovačic and the others v. Slovenia (3 October 2008) also belongs to the same group. Namely, it dealt with the consequences of the break-up of the Socialist Federal Republic of Yugoslavia and its banking system and, ultimately, the redistribution of liability for old foreigncurrency savings among its successor States. As some of the applicants have received the full amount of their foreign-currency deposits plus accrued interest, while others had cases pending in a court to recover foreign-currency deposits, the applications were accordingly struck out of the list.

839 The ECtHR relied on CC Decision No. U-I-284/94 holding that the transfer of the names of the "erased" from the Register of Permanent Residence to the Register of Aliens without a Residence Permit had no domestic legal basis. It relied on the subsequent decision No. U-I-246/02 which found certain provisions of the Legal Status Act to be unconstitutional as it had failed to grant the "erased" retroactive permanent residence permits and to regulate the situation of those who had been deported.

${ }^{840}$ All the compensation claims were eventually dismissed, mostly for failure to comply with the prescribed statutes of limitation. In one case the first instance court had initially held in an interim judgment that there were grounds for holding the State liable for damages. However, the Supreme Court upheld the secondinstance decision dismissing the claim on account of the expiry of the statutory time-limit for filing a lawsuit. A constitutional complaint was lodged; however, the CC did not accept it for consideration on the merits.

${ }^{841}$ After the Declaration of Independence the difference between the "old" aliens (citizens of States other than the former Yugoslav republics) and the "erased" evaporated - their situation became at least comparable. However, as an effect of "erasure", only members of one of these groups could keep their residence permits. ${ }^{842}$ At the time of accomplishing this text, the Government has not yet met its obligation. 
The right to a fair trial was at issue in the cases of Flisar, Suhadolc, Berdajs, Marguč, Milenović and Mesesnel, all concerning a common aspect of this right, namely the right to be heard in proceedings. Even the person undergoing prosecution of a minor offence is in principle entitled to a hearing before the tribunal examining his or her case, unless there existed exceptional circumstances which justified that such a hearing was not carried out. The ECtHR has accepted such exceptional circumstances in cases not belonging to the traditional categories of criminal law, where the issues at stake were of a rather technical nature. In the cases of Flisar v. Slovenia (29 September 2011), Milenović v. Slovenia (28 February 2013), and Mesesnel v. Slovenia (28 February 2013) a violation of the first paragraph of Article 6 of the ECHR was established. As the ECtHR set forth in the Flisar judgement, the national local court upheld the police's decision on the basis of the file forwarded by the police, which contained the payment order, the statement of facts, and the applicant's request for judicial review, without examining the witnesses proposed by the applicant - despite the fact that the case concerned an offence of alleged violent and aggressive behaviour which had been personally observed by police officers and the officers' observations had been the sole basis of the applicant's conviction. The situation in the case of Suhadolc v. Slovenia (17 May 2011), which concerned evidence obtained by means of an objective method, namely the use of a speed measuring device and an alcohol test, was however quite different.

The case of Eberhard and M. v. Slovenia (1 December 2009) concerned the right to respect for family life, particularly the mutual enjoyment by parent and child of each other's company. The ECtHR concluded that the Slovene authorities had failed to make adequate and effective efforts to execute the access order specifying arrangements for the applicant's access to his daughter. ${ }^{843}$ It further found that the court proceedings concerning access and custody rights had not been conducted effectively, in particular not promptly, as required by Article 8 of the ECHR. ${ }^{844}$ As a result of all these shortcomings, the applicant had almost no contact with his daughter for more than four years.

\section{The effects of the European Court's Case Law on National Law}

\subsection{General observations}

As the jurisprudence of the ECtHR belongs to the international-law system of measures which are not vested with the ability of coercive implementation, it doesn't have any immediate binding effect on the legal systems of the respective states. That is why the Strasbourg Court and the Committee of Ministers which supervises the execution of ECtHR judgments (its essential function is to ensure that member states comply with the judgments) have no power to interfere with the authority of the respective state. Therefore, the judgements of the ECtHR are due to their very international-law nature mostly declaratory, holding whether there was a violation of the respective human right except in the part where they order a State to pay just satisfaction according to Article 41 of the Convention. The Court is not vested with a power to quash a challenged domestic court's decision and remand the case for new adjudication, neither can the ECtHR order the reopening of a case - yet it could recommend that step to be undertaken, as the most appropriate mode of reparation.

\footnotetext{
${ }^{843}$ The ECtHR observed "[...] that fines, even if they were capable of compelling M.E. to comply with the access arrangements, were never actually executed. Further, the attempts by the Šentjur Centre (Social Welfare Centre) to organise supervised meetings failed as M.E. refused to cooperate, but there is no indication in the case file that any measures were taken in response to her lack of cooperation or that this would have any consequences for her." In addition, "[...] no other measures were taken by the authorities to create the necessary conditions for executing the order in question, be they coercive measures against M.E. or preparatory steps for contact between the applicant and M."

844 The court proceedings in which the applicant sought custody of his daughter lasted for more than four years and six months (and terminated with a settlement between the parties); during the first three years, the applicant only had contact with his daughter on three occasions.
} 
However, the enlargement of the Council of Europe in the 1990's gave rise to proliferation of the ECtHR's work load. Namely, thousands of cases were (and still are) coming from the newer member states, many of them revealing a "structural dysfunction in the operation of legal systems". 845 Hence the ECtHR found itself under a pressing need to develop a procedure which would enable it to tackle the issue of systemic and structural problems which were at the root of repetitive cases. The invention of the pilot procedure or in other words a shift to a quasi-constitutional role of the ECtHR was thus inevitable. As W. Sadurski pointed out, the emergence of pilot judgements is an important symbolic step on the path to a growing "constitutionalisation" - through effective superiority and justiciability - of the Convention, and the growing "constitutionalisation" of the ECtHR. ${ }^{846}$ However, by accepting the pilot judgement procedure, the ECtHR has denied the erga omnes effect of its judgements - as Judge Zupančič shrewdly discovered. Namely, his proposition was that the pilot judgement procedure compensated for the fact that the Court's judgements were not in practice binding on the states. ${ }^{847}$

\subsection{The Legislative level}

As already mentioned, so far three pilot judgements have been delivered against Slovenia. Two of them are already final; the third has been referred to the Grand Chamber. The Lukenda judgement (demanding the introduction of appropriate legal measures and administrative practices to secure the right to a trial within a reasonable time) triggered the comprehensive so called Lukenda Project, a package of reforms with the goal of eliminating court backlogs by the end of 2010. The central position belonged to the Act Regulating the Protection of the Right to a Trial without Undue Delay, which was introduced in January 2007. The Act stipulated the maximum time limits for case processing in courts and issued standards for the length of procedures, further it introduced accelerative remedies and provided adequate redress for a violation that occurred despite the fact that all accelerative remedies had been exhausted. Moreover, the Civil Procedure Act was amended in order to make civil proceedings more effective, hence introducing measures enabling proceedings to be more concentrated, providing sanctions for failing to respond to court summons, ${ }^{848}$ stipulating that appellate courts could not quash the challenged decisions and remand cases to lower courts; additionally, amendments were made for the encouragement of mediation. Some administrative actions were undertaken as well: 140 new judges, 650 new technical personnel and 175 administrative staff were appointed to help expedite proceedings. ${ }^{849}$

Nevertheless the package of reforms was only partially successful. Backlogs and the problem of excessive length of proceedings remained. The only benefit (which is, however, regarded as decisive from the Strasbourg perspective) entails the mechanism providing for just satisfaction for delays that have already occurred. Thus the ECtHR was the only subject (apart from the persons obtaining such satisfaction) which drew some profit from the Lukenda Act. ${ }^{850}$ Later on, the case of Lesjak v. Slovenia

845 L. Wildbacher, A Constitutional Future for the European Court of Human Rights?, Human Rights Law Journal, Vol. No. 23 (2002), p.164.

846 W. Sadurski, op. cit., 450.

847 Interview with Judge Zupančič, Strasbourg, 26 March 2009, quoted in P. Leach and others, op. cit., p. 14.

848 However, most of such amendments were later set aside by the CC (due to their unconstitutionality).

849 P. Leach and others, op. cit., p. 88. However, the new (additional) appointments proved unsuccessful. See V. Dimitrova Grajzl, P. Grajzl, J. Šušteršič, K. Zajc, Court output, judicial staffing, and the demand for court services: Evidence from Slovene courts of first instance, International Review of Law and Economics, Vol. 32, Issue 1, March 2012, pp.19-29. The article examines how judicial staffing and caseload influence court output in Slovenia (a post-socialist EU member state struggling with implementing an effective judicial system), addressing the problem of reverse causality between court output and both caseload and judicial staffing. The judicial efficiency is raised by increasing demand for judicial services, rather than by the increased number of judges.

850 In the case of Žunič v. Slovenia (18 October 2007) the ECtHR stated that "[...] a remedy is 'effective' if it can be used either to expedite the proceedings or to provide adequate redress, such as just satisfaction, for delays 
(21 July 2009) revealed some deficiencies of the Lukenda Act (regarding delays incurred during proceedings before the Supreme Court) which were eliminated (by amendments of the Act) just a week before the Lesjak judgement was delivered. The story was concluded by the CC's decision in case Nos. U-I-207/08, Up-2168/08 (18 March 2010) and thus once more demonstrated a "coincidence of interests" as between the CC and the ECtHR. ${ }^{851}$ As already mentioned, the CC found a violation of the right to a trial within a reasonable time, since the legislature did not regulate the status of the injured parties who claimed just satisfaction before national courts in the same manner as it regulated the status of persons who claimed just satisfaction before an international court under Article 25 of the Act Regulating the Protection of the Right to a Trial without Undue Delay. 852

The case of Matko v. Slovenia could also be classified into the group of "third tier" pilot judgements. ${ }^{853}$ Even though the Court didn't explicitly hold that the problem at issue (the police brutality) was systemic, it noted that a similar investigation had been criticised in the case of Rehbock v. Slovenia. Moreover, to support its conclusions, the ECtHR referred to a (at that time) recent Slovene CC decision (Nos. Up-555/03-41, Up-827/04-26, dated 6 July 2006) in a case concerning a person who had died during a planned police operation and in which an interference with several constitutional rights of the deceased and his wife had been alleged. Legislature responded by amending the State Prosecutor's Act which introduced measures for the investigation of any alleged malpractice by the police or other home affairs officials and re-established the State Prosecutor's Office responsibility for directing the investigation and ensuring its impartiality.

\subsection{The Judiciary}

As mentioned above, the Constitutional Court regularly refers to Strasbourg case law. Only few CC decisions on the merits regarding human rights and fundamental freedoms contain no reference to ECtHR case law. And so far none of the CC's decisions has been consciously taken contrary to ECtHR case law. Both courts have demonstrated a good cooperation and allied relations on several occasions. Pilot judgements are characteristic in this regard. The case of Kurić and others v. Slovenia showed the alliance between the two courts in its full dimension and strengthened the position of the CC significantly - and, vice versa, the ECtHR's judgement has gained strength from the CC's decisions and their reasons. ${ }^{854}$ The indirect and implied message from Strasbourg was (and still is) clear: respect and implement the CC decision! By providing for such, the ECtHR made the execution of the domestic CC decision subject of the international obligation of the state. This viewpoint reveals the horizontal (mutually active) relationship between the ECtHR and the national CC.

The other axis of the relationship between these two tribunals is the vertical. Even though the international binding effects of a pilot judgement are limited on the respective state (inter partes effect - see paragraph 1 of Article 46of the ECHR), its effects on the national (state's) level are general - erga omnes. Since a state must abide by the final judgment of the Court in any case to which it is a party, all of the state's bodies are thus bound by that judgement. It is incumbent upon the state as an entity in its whole integrity to implement a pilot judgement (in this respect the phenomenon of "piercing the veil of the State" 1855 should be overlooked); irrespective of the question on which branch of power the particular duty falls. If it is the legislature and it fulfils its obligation (by passing an act introducing the requested measures), it is then for the judiciary to interpret the

that have already occurred [...]"

851 See P. Leach and others, op. cit., p. 128.

852 The Act may be accessed at:

http://www.mp.gov.si/fileadmin/mp.gov.si/pageuploads/mp.gov.si/zakonodaja/angleski_prevodi_zakonov/12

1212_Act_on_the_Protection_of_the_Right_to_a_Trial_without_Undue_Delay_eng.pdf

${ }^{853}$ See P. Leach and others, op. cit., p. 97-98.

854 Mostly from the decision No. U-I-284/94 (4 February 1999).

855 A formula used by S. Besson in her lecture on 19 August 2008 in Sidney "The Authority of International Law", The 2008 Annual Julius Stone Address (quoted in W. Sadurski and others, op. cit., pp. 399, 421). 
respective legislative measures in a way coherent with the pilot judgement's reasons and the aim pursued therein. This interpretation should not be conducted in such a manner that the core message and the essence of the pilot judgement would be hollowed out (and thus the internationallaw obligation outmanoeuvred). ${ }^{856}$

Due to the abovementioned constitutional principle of the highest protection of human rights (the fifth paragraph of Article 15 of the Constitution) the role of the Slovene CC could be described as the executing assistant of the ECtHR. Namely, according to the principle of subsidiarity and according to the principle of the highest protection of human rights, the CC is performing the abstract, the individual, and the concrete control over governmental acts of all the state's bodies (directly or indirectly) that are bound by the pilot judgement.

Despite the good relations between the ECtHR and the Slovene CC a slight controversy arose in the case of Gaspari v. Slovenia (21 July 2009). The Strasbourg Court found a violation of the right to adversarial proceedings as the constitutional appeals lodged by the other party to the proceedings had not been communicated to the applicant. Hence the ECtHR found that the applicant was not given the chance to participate properly in the proceedings before the Constitutional Court and thus the latter deprived her of a fair hearing. Despite the violation having been established, the ECtHR did not award the applicant compensation in respect of pecuniary damage (due to the fact that the existence of a causal link between the violation found and the alleged damage was not demonstrated). The ECtHR sent the following message:"[T]he most appropriate form of redress in respect of a violation of Article 6 is to ensure that the applicant as far as possible is put in the position he or she would have been had the requirements of Article 6 not been disregarded. This would in the present case be best achieved, if the domestic legislation provided for a possibility to reopen the proceedings and re-examine the case in keeping with all the requirements of a fair hearing. [...] Whatever the case may be, the Court considers that the lack of Article 6 guarantees in the proceedings at issue caused the applicant distress which cannot be made good by the mere finding of a violation." 857

The applicant from the proceedings before the ECtHR later submitted an application to the CC for the reopening of the constitutional complaint proceedings which were previously concluded by CC Decision No. Up-140/02, dated 12 December 2002. She substantiated her application by referring to the abovementioned judgment of the ECtHR. At the same time, she submitted a petition to initiate proceedings for the review of the constitutionality of the Civil Procedure Act and of the Constitutional Court Act, in the event the CC assessed that the challenged acts could not be interpreted so broadly as to allow for a reopening of the proceedings. The CC dismissed the petition to initiate proceedings for the review of constitutionality and rejected the application for the reopening of the proceedings with the constitutional complaint. ${ }^{858}$ It clearly stated that it is not within the jurisdiction of the ECtHR to require the contracting state to adopt precisely defined measures. A contracting state can select appropriate measures to redress the consequences of an individual act that is disputed, or measures by which it will be able to ensure that its national legislation is consistent with the requirements of the ECHR. Only in exceptional cases, when a violation is of such nature that it excludes any possibility of selection of measures, does the ECtHR direct the contracting state to adopt a precisely defined measure. The CC pointed out that in its reasoning in the case of Gaspari v. Slovenia, the ECtHR did in fact note that the most appropriate

\footnotetext{
856 See Slovene CC Decision Nos. U-I-223/09, Up-140/02 (14 April 2011) in which the Court held: "The binding force of ECtHR final judgments does not entail that only the legislature is obliged to abide by them, but rather that also national courts must strive to interpret national regulations in accordance with the requirements of the ECHR. Such a requirement follows also from Article 1 of the ECHR, which obliges contracting states to ensure the compatibility of national legislation with the requirements of the Convention."

857 The case of Gaspari v. Slovenia, para. 80.

858 CC Decision Nos. U-I-223/09, Up-140/02.
} 
form of redress would be to reopen the proceedings and thus ensure that the applicant is put in the position she would have been in had the requirements of Article 6 of the ECHR not been disregarded.

However, the reasons on which the ECtHR based its judgment in the present case do not necessarily entail that thereby the CC has an obligation to unconditionally implement the specific measure of reopening the constitutional complaint proceedings in the applicant's case. It is not within the jurisdiction of the ECtHR to order the reopening of national judicial proceedings. Therefore, such a statement in the reasoning of the ECtHR judgment can only be interpreted as an indication of a possible measure which could be, in the assessment of the ECtHR, appropriate to redress the consequences of the established violation. Namely, the Constitutional Court Act does not provide for the possibility to reopen constitutional complaint proceedings. In one of its panel orders, the Court did, however, adopt the standpoint that in the event that an obvious administrative error occurred in constitutional complaint proceedings, it could re-examine the constitutional complaint in question. Nevertheless, the case at issue was not such a case, since the applicant requested the reopening of the constitutional complaint proceedings on the basis of the existence of an ECtHR judgment in which the existence of such an error of the Constitutional Court had already been established.

It seems to be uncontested that the primary responsibility to safeguard human rights lies with ordinary courts (courts of general jurisdiction). ${ }^{859}$ According to the principle of subsidiarity (being expressed through the demand to exhaust legal remedies), parties are required to invoke their human rights primarily in proceedings before the ordinary courts. Following the principle of the highest protection (the fifth paragraph of Article 15of the Constitution), ordinary courts are at least indirectly and implicitly bound by international instruments regulating human rights (see above pp. 10-11). Hence they have a duty to interpret statutory law in conformity with the Constitution and, through the principle of the highest protection, in conformity with international instruments regulating human rights, ordinary courts have been turned into miniature constitutional tribunals. ${ }^{860}$ Therefore, ordinary courts should be expected to refer to the ECHR and the case law of the ECtHR. Such also applies to the Supreme Court; ${ }^{861}$ whereas lower courts, unlike the Supreme Court, rarely refer to the ECHR and ECtHR case law.

In any event, a review of the case law leads to the conclusion that the ECHR supplemented by ECtHR case law is integrated into national case law by the "middleman" - the decisions of the CC. ${ }^{862}$ The opinion that this is the natural and logical way (deriving this conclusion from the fact that Constitutional Courts are in one way or another constantly paying attention to whether their legal systems comply with the Constitution and provisions of international law- hence the application of the minimal (quasi-constitutional) standards of the ECHR is just a part of their general modus operandi) $^{863}$ could be questioned. Namely, it disregards the gradual change in the position of Constitutional Courts in Europe, being a consequence of the process of constitutionalisation of statutory (mostly civil) law, requiring constitutionally conform interpretation of (statutory) Laws. Even though only few provisions of the ECHR are directly applicable, that doesn't diminish the impact of the Constitution and the ECHR on the process of discovering the substance of provisions of

\footnotetext{
859 See CC Order No. Up-139/99 (30 May 2000). See also A. Galič, Varstvo človekovih pravic pred rednimi sodišči [Protecton of Human Rights before the Ordinary Courts], Podjetje in delo, No.. 6-7 (2010), p. 1047.

${ }^{860}$ See M. Bobek, Quantity or Quality? Reassessing the Role of Supreme Jurisdictions in Central Europe, in: The American Journal of Comparative Law, Vol. 57 (2009), No. 1, p. 59.

${ }^{861}$ The trend of cases in which the Supreme Court has referred to ECtHR case law seems to be increasing. In the period 2000-2001 9 references were made, in the period 2002-2003, 5, in the period 2004-2005, 11, in the period 2006-2007, 22, in the period 2008-2009, 46, and in the period 2010-2011, 92 (see N. Betetto, Vpliv Evropske konvencije za človekove pravice na slovensko sodno prakso[ The Impact of the European Convention for the Protection of Human Rights and Fundamental Freedoms on Slovene case law], Podjetje in delo, No. 6-7 (2012), p. 1238)

862 See N. Betetto, op. cit., p. 1246.

863 Ibid., pp. 1246-1247.
} 
statutory law. As M. Bobek pointed out, "[t]hrough the 'Ausstrahlungswirkung' and the duty of the court of general jurisdiction to interpret 'ordinary law' ('einfaches Recht') in conformity with the Constitution (and, by application, with the case law of the constitutional court), courts of general jurisdiction were turned into miniature constitutional tribunals." 864

\section{Remedies}

In the abovementioned case of Gaspari v. Slovenia (and in several other cases) ${ }^{865}$ the ECtHR noted that the most appropriate form of redress would be to reopen the proceedings and thus ensure that the applicant is put in the position he or she would have been in had the requirements of Article 6 of the ECHR not been disregarded. In the assessment of the Slovene CC, the requirement to ensure such a subsequent legal remedy does not follow from Article 13 of the ECHR. It further opined that even the fourth paragraph of Article 15 of the Constitution does not require the possibility to reopen (in the case at issue constitutional complaint) proceedings on the basis of the ECtHR judgment. Namely, the requirements determined by the mentioned constitutional provision ${ }^{866}$ can also be met by ensuring the right to financial compensation or even simply by establishing the violation as such. ${ }^{867}$ However none of these measures are capable to re-establish the balance - that could only be done by restitutio in integrum..$^{868}$

Due to some additional reasons the possibility to reopen the disputed civil proceedings or the disputed outcome of domestic civil proceedings seems to be even more questionable. Not only in the light of the prevailing approach of the member states of the Council of Europe (most of them having long and respectable legal traditions), but most of all also the excessive duration of the proceedings before the ECtHR (and thus loosening social peace and legal certainty, both based on the final resolution of the legal dispute) and the fact that the opponent (adversary) in the domestic civil proceedings is not granted the right to participate in the proceedings before the ECtHR as a party (she or he has only the possibility to intervene - see Article 36 of the ECHR), the institution of an extraordinary legal remedy based on the Strasbourg's judgement would probably be contrary to the mentioned constitutional requirements (i.e. the right to participate in proceedings and legal certainty). ${ }^{869}$ For such reason an ECtHR judgement could serve as a special ground for the reopening of domestic proceedings only in criminal cases. Namely, those cases that are nothing but disputes between the state and the accused individual; hence in criminal cases the convicted person (the applicant) can only benefit from an ECtHR judgement. Therefore, the Criminal Procedure Act legitimately provides for the reopening of criminal proceedings on the ground of a judgement of the ECtHR establishing a violation of the applicant's right (Articles 416 and 421 of the Criminal Procedure Act). The reopening of the proceedings cannot at any rate damage the opposite party's interest or the value of the certainty of the final resolution of a dispute.

\footnotetext{
${ }^{864}$ See M. Bobek, op. cit., p. 59.

865 See the ECtHR judgments in the cases of Somogyi v. Italy, dated 18 May 2004, para. 86; Öcalan v. Turkey, dated 12 May 2005, paras. 208 through 210; Lungoci v. Romania, para. 56; and Yanakiev v. Bulgaria, dated 10 August 2006, para. 90.

866 The fourth paragraph of Article 15 of the Constitution is worded as follows: "Judicial protection of human rights and fundamental freedoms, and the right to obtain redress for the violation of such rights and freedoms, shall be guaranteed."

867 See CC Order No. Nos. U-I-223/09, Up-140/02 (14 April 2011).

${ }^{868}$ See the judgement in the case of Hentrich $v$. France (22 September 1994) in which the ECtHR held that there had been a breach of Article 1 of Protocol No. 1 and considered that he best form of redress would in principle be for the State to return the land (para. 71).

${ }^{869}$ See A. Galič, Sodba ESČP - nov razlog za obnovo pravdnega postopka?[The Judgement of the ECtHR - a new ground for the reopening of civil litigation?], Pravna praksa 2002, No. 6, Supplement, pp. I-III.
} 


\section{Dissemination}

\subsection{Teaching}

Teaching: There are three law faculties in Slovenia (in Ljubljana, in Maribor, and in Nova Gorica), which provide undergraduate studies (the first cycle). All of them require students to take courses in Constitutional Law and European Constitutional Law (both inter alia encompass teaching about the international protection of human rights and freedoms); an elective course in European Law of Human Rights is offered at the Law Faculty in Ljubljana. The second cycle of studies at the Law Faculty in Ljubljana offers inter alia a course on the Constitutional guarantees in civil proceedings (which also encompasses the ECtHR's case law as regards the right to a fair trial) and a course in Constitutional Procedural Law, while the same level at the Law Faculty in Maribor includes a course on the System of judicial protection within the Council of Europe and in the EU. The postgraduate study at the European Law Faculty in Nova Gorica also comprises a course on the Theory and practice of the social state, a course in Constitutional and International Criminal Law, and a course in Constitutional and International Law of Human Rights. The Graduate School of Government and European Studies at Brdo pri Kranju provides a course in Constitutional and International Law of Human Rights and a course in Comparative Constitutional Law in the framework of the master's degree program. All these courses concern Conventional law (including the ECtHR's case law).

\subsection{Scholarship}

There are only two specialized journals for human rights law and hence concerning the ECtHR's case law: Dignitas and Revus. The journal Dignitas is specialized in the area of domestic constitutional and international law of human rights. It is published by The Graduate School of Government and European Studies at Brdo pri Kranju (Slovenia) in collaboration with the European Faculty of Law in Nova Gorica (Slovenia). The journal is published under the auspices of the Slovene section of the International Commission of Jurists and the Slovene Comparative Constitutional Law Association. The first issue of the journal was published in 1999 and the most recent issue in December 2012. In addition to over 20 regular issues published over the past ten years, a number of special thematic issues was published. The journal Revus (European Constitutionality Review) covers a wide range of fields, encompassing the foundations of the Western Balkans legal cultures, and focusing on constitutional law in its widest sense. However, in addition to constitutional courts' law-making and institutional constitutional law of the Council of Europe, the European Union and individual SouthEast European countries, Revus is oriented towards international public law, theory and philosophy of law, human rights, rule of law and democracy. It also values comparative law, going beyond regional and European borders. Other law journals cover all fields of law and most of them are not focused on particular issues and topics; however they regularly publish articles, essays, and treatises on the topic of human rights and Conventional law. The weekly paper Pravna praksa [Legal Practice], published each Thursday, regularly provides information on current Strasbourg case law with short comments and guidelines for further research.

\subsection{Judiciary}

In general, the ECtHR's case law is disseminated in two ways. One is through the annual judicial school and through periodical lectures organised by the Association of judges. Another instrument for dissemination consists of the regularly issued internal paper Sodnikov informator [Judge's informant], which provides basic information on current ECtHR's decisions. In any case, some judges also attend seminars, symposiums, and congresses held in Slovenia and abroad. 


\subsection{Lawyering}

Lawyers are informed in a similar way - through lectures, held periodically (mostly once a year on the annual meeting of the Bar), and through law journals (one of them, Odvetnik [The Lawyer], is published by the Bar Association of Slovenia).

\section{The influence of the case-law and the democratisation process}

\subsection{Political Pluralism}

There have been only a few cases brought before the CC concerning political pluralism, and only in three of them the CC referred to ECtHR case law. Furthermore, it has touched upon the topic merely on the surface and indirectly. In Case No. U-I-155/07 (Decision of 9 April 2009) the CC cited the case of Gorzelik v. Poland (judgement of 20 December 2001) when advancing the opinion that one of the aspects of freedom of association determined in the second paragraph of Article 42 of the Constitution is that individuals have the possibility to establish a legal entity for collective action in the sphere of their common interests. While referring to the case of Vogt v. Germany (judgement of 26 September 1995), it further stated that the state is obliged to ensure appropriate mechanisms in cases when an individual could suffer some harmful consequences (e.g. discrimination, vexation, different forms of penalisation) due to his or her affiliation with certain associations.

Another case brought before the CC concerned the collision between the freedom to inform the public and the right to fair elections (Decision Nos. U-I-67/09, Up-316/09 of 24 March 2011). The CC reviewed the constitutionality of the challenged second paragraph of Article 5 of the Elections and Referendum Campaign Act which prohibited the mass media from publishing any public opinion polls during the period of seven days before the elections. The CC emphasized that we can only speak of fair elections or voting when the true will of the people is expressed and if during such processes the public is also extensively and comprehensively informed. Hence the challenged seven-day prohibition was found to be a disproportionate limitation that excessively interfered with the free functioning of the mass media. The CC referred to the ECtHR's principled standpoint that at the time of elections the freedom of expression should be treated in the light of Article 3 of Protocol No. 1 which provides for the right to regular, free and fair elections. Namely, as the ECtHR stated in the case of MathieuMohin and Clerfayt v. Belgium (judgment of 2 March 1987 - later reiterated in the case of Bowman v. the United Kingdom, judgement of 19 February 1998), "[f]ree elections and freedom of expression, particularly freedom of political debate, together form the bedrock of any democratic system." ${ }^{170}$ Free elections and the freedom of expression, especially the freedom of political discussion, together form the foundation of each democratic system. The freedom of expression is just one of the essential prerequisites for assuring the free (s)election of men and women, entrusted to compose the structure of the legislative body. The CC continued citing the aforementioned case: "The two rights are inter-related and operate to reinforce each other." However in certain circumstances those freedoms could collide with each other. In such cases "it may be considered necessary, in the period preceding or during an election, to place certain restrictions, of a type which would not usually be acceptable, on freedom of expression, in order to secure the free expression of the opinion of the people in the choice of the legislature" ${ }^{871}$

The third relevant CC case was related to the naming of one of the streets in Ljubljana after the former Yugoslav communist leader Tito. ${ }^{872}$ While annulling Article 2 of the Ordinance on Determining and Changing the Names and Course of the Roads and Streets in the Territory of Ljubljana Municipality, as it violated the principle of respect for human dignity, the CC referred to the ECtHR

\footnotetext{
870 The case of Bowman v. the United Kingdom, para. 42.

${ }^{871}$ CC Decision Nos. U-I-67/09, Up-316/09, para. 12.

872 CC Decision No. U-I-109/10 (26 September 2011).
} 
case of Vajnai v. Hungary (judgement of 8 October 2008). In this case the ECtHR on the contrary held that the prohibition on wearing the red star is an inadmissible interference with Article 10 of the ECHR, which guarantees freedom of expression, however it pointed out that there is an important difference if an individual wears such red star during a political speech or if a bearer of public authority when exercising power identifies with such symbol (paragraphs 48 and 49 of the reasoning).

\subsection{Equality before the law}

In this regard again only three cases - all of them dealing with the abstract review of the constitutionality of laws - should be outlined. Namely, only in these "equality" cases the CC cited the jurisprudence of the ECtHR. The first concerned the position of blind and partially sighted persons in civil proceedings (Decision No. U-I-146/07, dated 13 November 2008). In the beginning, the CC explained that in order to determine a violation of the constitutional prohibition against discriminatory treatment, it is sufficient to establish the existence of inadmissible discrimination in the enjoyment of any human right, whereas a petitioner does not need to demonstrate an interference with this human right. ${ }^{873}$ The CC further ruled that the existing civil procedure regulation did not ensure this disadvantaged social group the necessary and appropriate accommodations which would enable them to exercise their right to fair treatment in proceedings (Article 22 of the Constitution) on equal terms with others. Such omission of the legislature entailed a constitutionally inadmissible interference with their right to non-discriminatory_treatment. In this regard the CC pointed out that following the recent case law of the ECtHR, the right to non-discriminatory treatment in enjoying Convention rights is violated not only in cases in which a state without an objective and sound reason treats persons in similar situations differently, but also in cases in which a state without an objective and sound reason does not treat persons whose positions are relevantly different differently. ${ }^{874}$

The next case concerned the position of partners living in registered same-sex partnerships regarding the right to inheritance following the death of one's partner (Decision No. U-I-425/06, dated 2 July 2009). The CC found the position of those partners in its essential factual and legal aspects comparable with the position of spouses. Therefore, it concluded that the differences in the regulation of inheritance between spouses and between partners in registered same-sex partnerships are not based on any objective, non-personal circumstance, but on sexual orientation. As sexual orientation is one of the personal circumstances determined in the first paragraph of Article 14 of the Constitution, (this provision prohibits discrimination in ensuring, exercising, and protecting human rights and fundamental freedoms regarding individuals' personal circumstances), and due to the fact that no constitutionally admissible reason could be found for such differentiation, the CC found the challenged provision (regulating the inheritance of the separate and joint property of registered partners differently than the general regulations on inheritance between spouses) inconsistent with the first paragraph of Article 14 of the Constitution. The CC here reiterated its previous standpoint regarding the autonomous nature of the Article 14 and again referred to the aforementioned case of Thlimmenos v. Greece.

\footnotetext{
${ }^{873}$ Reference was made to the recent ECtHR's case law which superseded a dependant, ancillary nature of the right to equality in accordance with which the violation of Article 14 of the ECHR could be successfully enforced only in connection with the violation of one of the Convention rights. The ECtHR namely emphasizes that the application of Article 14 of the ECHR no longer presupposes a breach of other Convention rights and that therefore Article 14 of the ECHR is to this extent autonomous. For Article 14 to become applicable, it suffices that the facts of a case fall within the ambit of another substantive provision of the ECHR or its Protocols (cf. Thlimmenos v. Greece, Judgment dated 6 April 2000, para. 40).

874 The CC referred to the abovementioned case of Thlimmenos v. Greece; for a more detailed consideration of this question, see Olivier De Schutter, Reasonable Accommodations and Positive Obligations in the European Convention on Human Rights, in: A. Lawson and C. Gooding (eds.), Disability Rights in Europe: From Theory to Practice, Hart, Oxford and Portland, Oregon 2005, p. 52.
} 
Also the third case concerned the right to (legal) inheritance between same-sex partners; however between partners in the so-called actual stable same-sex partnership (Decision No. U-I-212/10, dated 14 March 2013). The CC found that the position of such partners is, from the viewpoint of the human right to (legal) inheritance (from a deceased partner), in its essential factual basis comparable to the position of common-law partners. Since the legislature omitted the determination of the legal consequences in the field of legal inheritance also of partners in an unregistered same-sex partnership (equally as it determined such for common-law partners), such same-sex partners are inadmissibly discriminated against. Such differentiation in the regulation of inheritance is not based on any factual, impersonal circumstance, but on sexual orientation, and the legislature did not state a constitutionally admissible reason for such differentiation. Even though the case seems to be just a logical and consistent continuation of the previous case (Case No. U-I-425/06), the CC, when reiterating and strengthening its prior viewpoints, added some fresh arguments, based on the ECtHR's case law. Above all, the CC paid attention to the cases dealing with analogical (relevantly similar) situations and found support for its statement that there are no essential and fundamental distinctions between same-sex couples and different-sex couples in the Strasbourg case law; such follows especially from the cases Schalk and Kopf $v$. Austria (judgement dated 24 June 2010) and P.B. and J.S. v. Austria (judgement dated 22 July 2010). Following the evolution of social attitudes towards same-sex couples which has taken place in many countries throughout Europe (a considerable number of Member States have afforded legal recognition to same-sex couples), the ECtHR adopted the view, that "[...] the relationship of the applicants, a cohabiting same-sex couple living in a stable de facto partnership, falls within the notion of 'family life', just as the relationship of a different-sex couple in the same situation would." The CC also concluded, referring to the ECtHR's case law, that (only) that essential factual basis (so-called tertium comparationis) should be extracted from both comparing situations which are comparable as regards particular legal entitlement at stake. ${ }^{875}$

\subsection{Due process}

The ECtHR's jurisprudence regarding the right to a fair trial had a significant influence on Slovene case law; not only on the CC's case law but also on the case law of ordinary courts as well. The vast majority of citations of the ECtHR's case-law belong to interpretations of different aspects of the right to a fair trial. Standards for the protection of such were set up in CC Decision No. Up-39/95 (dated 16 January 1997), even though the Court did not expressly refer to the ECtHR's case law.876 Therefore just some starting-points and aspects of the right to a fair trial (in its narrow sense) as developed through the Strasbourg jurisprudence and assumed by Slovene courts will be presented here.

i) First, it should not be disregarded that the right to a fair trial has an autonomous and intrinsic value - a fair trial is a value per se. For this reason there is no justification for interpreting the guarantees of the first paragraph of Article 6 of the Convention conditionally, i.e. depending on its influence on the final decision of a court in specific proceedings. Even if the breach of the right to a fair trial has no influence on the outcome of the substantial resolution of the dispute, it constitutes a violation of the Conventional (and Constitutional) value. ${ }^{877}$

\footnotetext{
875 Here the CC referred to the case of J.M. v. UK (judgement dated 28 September 2010) and the case of Kozak v. Poland (judgement dated 2 March 2010). However in the case of Gas and Dubois v. France (judgement dated 15 March 2012) the ECtHR considered that, for the purposes of second-parent adoption, the applicants' legal situation (living in a civil partnership) cannot be said to be comparable to that of a married couple.

876 The stress was laid on the principle of adversarial proceedings as an expression of the right to equal protection in procedures. The CC emphasized that parties must be guaranteed the right to be present at the taking of evidence, to put questions to witnesses or expert witnesses, and then be informed on the results of the hearing of evidence, and in relation to this also to provide their legal opinion.

877 See judgements in the cases of A. B. v. Slovakia (dated 4 March 2003) and P., C. and S. v. the United Kingdom (dated 16 July 2002).
} 
ii) Second, the right to a fair trial incorporates diverse aspects of procedural fairness - first of all equality of arms and the principle of adversarial proceedings as an expression of the right to equal protection in procedures. However, it is not only the procedural equality, but also the right of the party to take an active part in the proceedings and the duty of the court to give the party an opportunity to influence the outcome of the proceedings, that are of central importance. The ECtHR reiterated several times that "each party must be afforded a reasonable opportunity to present their case - including their evidence - under conditions that do not place them at a substantial disadvantage vis-à-vis their opponent". Further the Court has emphasised in the case of Ziegler v. Switzerland (judgement dated 1 February 2002) that "[w] hat is particularly at stake here is litigants' confidence in the workings of justice, which is based on, inter alia, the knowledge that they have had the opportunity to express their views on every document in the file." The right to be heard (as a reflection of the equality of arms) could be divided into several sub-rights: the right to information

878 See the cases of Lobo Machado v. Portugal (judgment dated 20 February 1996) and K.S. v. Finland (judgment dated 31 May 2001). See also the cases of Frette v. France (judgement dated 26 February 2002) and Milatová and others v. The Czech Republic (judgement dated 21 June 2005). In the latter case the Court held: "As to consulting the case file at the Constitutional Court and obtaining a copy of any written observations, the Court is of the view that this is not in itself a sufficient safeguard to secure the applicants' right to an adversarial procedure. In its view, and as a matter of fairness, it was incumbent on the Constitutional Court to inform the applicants that the observations had been filed and that they could, if they so wished, comment on them in writing."

879 See the case of Georgiadis v. Greece (judgment dated 29 May 1997). See also the cases of Niderhöst-Huber v. Switzerland, (judgment dated 18 February 1997) and Walston (No.1) v. Norway (judgement dated 3 June 2003) recalling that it is for the applicants to judge whether or not a document calls for their comments.

880 See the cases of Nideröst-Huber v. Switzerland (judgment dated 18 February 1997) and Galich v. Russia (judgement dated 13 May 2008). The ECtHR stated that “'fairness' implies that the proceedings be adversarial in nature, which, in turn, requires that a court should not base its decision on evidence that has not been made available to each of the parties." See also the cases of Perić v. Croatia (judgment dated 27 March 2008) and Souminen v. Finland (judgement dated 1 July 2003)

881 The extent to which the duty to state reasons applies may vary according to the nature of the decision. However, the rationale of this duty should always be borne in mind: first, it is the obligation of a (democratic) authority to justify its activities by giving reasons for its decisions. It is clearly put forward in the case of Kushoglu v. Bulgaria (judgement dated 10 May 2007), where the court stated: "According to the Court's established case-law reflecting a principle linked to the rule of law and, therefore, to the requirement of lawfulness, judgments of courts and tribunals should adequately state the reasons on which they are based". Second, the function of a reasoned decision is to demonstrate to the parties that they have been heard and, third, only a reasoned decision affords a party the possibility to appeal against it, as well as the possibility of having the decision reviewed by an appellate body. Finally, it is only by giving a reasoned decision that there can be public scrutiny of the administration of justice (see the cases of Hirvisaari v. Finland, judgement dated 27 Sept 2001, and Souminen v. Finland, judgement dated 1 July 2003). The Slovene CC has even taken a step further in holding that the duty to state reasons has an intrinsic and autonomous value, rather than being just a mere reflection of the right to be heard (Decisions Nos. Up-147/09, dated 23 Septembre 2010, Up-162/09, dated 16 December 2010, and Up-1273/09, dated 13 October 2011).

882 The right to a "public hearing" under the first paragraph of Article 6 of the ECHR entails the entitlement to an "oral hearing" unless there are exceptional circumstances that justify dispensing with such a hearing. The exceptional character of the circumstances that may justify dispensing with an oral hearing essentially comes down to the nature of the issues to be decided on. For example, disputes concerning benefits under social-security schemes are generally rather technical, often involving numerous figures, and their outcome usually depends on the written opinions given by medical doctors. Many such disputes may accordingly be better dealt with in writing than in oral argument. Moreover, it is understandable that in this sphere the national authorities should have regard to the demands of efficiency and economy. Systematically holding hearings could be an obstacle to the particular diligence required in social-security cases (see the case of Miller v. Sweden, judgement dated 8 February 2005 and the case-law cited therein). On the contrary, when personal factors are at stake, a party must be afforded the right to explain his/her personal situation in a hearing before the court subject to public scrutiny (see the case of Göc v. Turkey, judgement dated 11 July 2002). 
(communication), ${ }^{878}$ the right to present arguments, ${ }^{879}$ guarantees in the process of the taking of evidence, ${ }^{880}$ the right to a reasoned judgement ${ }^{881}$ and the right to a public hearing. ${ }^{882}$

iii) Third, the question of fair trial encompasses the proceedings as a whole and not just a part of them. The ECtHR reiterated several times that its "[...] task is to ascertain whether the proceedings in their entirety, including the way in which evidence was taken and submitted, were fair within the meaning of Article $6 \S 1 .{ }^{\prime 883}$

iv) Fourth, the law making process is not only the legislature's business. The legislature provides "just" the bare legal wording, leaving the rest to the judiciary. Therefore, uniformity in adjudication represents a significant constitutional value. Although obliged to take into consideration uniform judicial practice, the judiciary (in Slovenia and in most European countries) is not formally bound to follow it. Even lower courts are allowed to depart from the case law of higher courts if there are good reasons (clearly explicated in the reasoning of a decision) to do so. Whether that condition is met, depends on a balancing of competing (constitutional) values. Unlike the German Federal CC and the Slovene CC, the Strasbourg Court has not expressly adopted the doctrine of the prohibition on arbitrary departure from the constant case law as one of the guarantees of fair trial. However, in few cases it (exceptionally) touched upon this problem. In the case Beian v. Romania (judgement dated 6 December 2007) the Court found that "[i]n the absence of a mechanism for ensuring consistency in its case-law, the highest domestic court delivered diametrically opposed judgments, sometimes on the same day." Such a practice, developed within the country's highest judicial authority, was in itself contrary to the principle of legal certainty, a principle which is implicit in all the Articles of the Convention and constitutes one of the basic elements of the rule of law. Therefore the ECtHR concluded that this lack of certainty with regard to the case law constituted a violation of the first paragraph of Article 6 of the Convention.

v) Fifth, the CC established the doctrine of the prohibition against judicial arbitrariness as one of the guarantees of procedural fairness. When a court's decision is not substantiated with reasonable legal arguments based on law (and prima facie appears as grossly wrong), the conclusion occurs that such a decision was driven by reasons other than legal-ones and hence constitutes a violation of the prohibition against judicial arbitrariness. ${ }^{884}$ In the ECtHR's case law it is well established and undisputed that the first paragraph of Article 6 of the ECHR does not guarantee a particular outcome in any case or that the "right result" will be reached by the domestic courts. However the ECtHR (similarly as the Slovene $\mathrm{CC}$ ) considered that a prima facie contradictory reasoning and the subsequent approval of such inadequate reasoning by a higher court as an appellate body, failed to fulfil one of the requirements of a fair trial. 885

vi) Sixth: The Slovene $\mathrm{CC}$ so far has not clearly expressed its standpoint regarding the infringement of the Supreme Court's obligation (or other court of last instance) to make a reference for a preliminary ruling. It just scratched the surface in the case Nos. Up-958/09, U-I-199/09886 holding that due to the fact that the Supreme Court dismissed the claim in the appellate proceedings without addressing the

\footnotetext{
${ }^{883}$ See the judgements in the cases of Dombo Beheer B.V. v. the Netherlands (dated 27October 1993) and Peric v. Croatia (dated 27 March 2008).

${ }^{884}$ See Decision No.Up-347/96 (dated 13 October 1999) in which the CC held: "The decision of the Supreme Court to reject as too late the complainant's suit in the framework of judicial review of administrative decisions was not based on any data included in the administrative files. By such an arbitrary decision the Supreme Court violated the complainant's right to equality in the (judicial) protection of rights determined in Art. 22 of the Constitution."

885 See the case of Hirvisaari v. Finland, judgement dated 27 September 2001. Compare also the case of Klasen v. Germany (judgement dated 5 October 2006), confirming the doctrine of prohibition against judicial arbitrariness as one of the limbs of fair trial, in which the ECtHR held "[...] that the reasons on which the German courts based their decisions are sufficient to exclude the assumption that their evaluation of the case had been arbitrary."

886 Decision dated 15 April 2010.
} 
essential allegations (particularly the allegations on the unconstitutionality of the statutory provisions which were the basis for the decision and the inconsistency of these provisions with the acquis communautaire), the Supreme Court, in the assessment of the Constitutional Court, did not satisfy the requirement that judicial decisions must contain a statement of reasons. The CC just added (as obiter dictum) that apart from what had been said before, the Supreme Court should consider the party's request to refer a question for a preliminary ruling to the Luxembourg Court. Consequently the CC has yet to explicate which aspect of the right to a fair trial is infringed in the case of a non-referral to the Court of Justice of the European Union (hereinafter CJEU). At any rate the Strasbourg case-law should be borne in mind. Above all, the ECHR does not guarantee the absolute right to have the issue of EU law discussed before the CJEU. However the ECtHR reiterated that there may be certain circumstances in which the refusal by a national court to refer a question for a preliminary ruling to the CJEU might infringe the principle of the fairness of judicial proceedings, particularly when it appears to be arbitrary. ${ }^{887}$

Nevertheless, the problem seems to be more complex. The preliminary ruling procedure provided for in Article 267 of the Treaty on the Functioning of the European Union is an instrument of cooperation between CJEU and national courts by means of which the former provides the latter with interpretation of such EU law as is necessary for them to give a judgment in cases upon which they are called to adjudicate. That being so the EU law obliges national courts to reason the decision to refer or not to refer a question for a preliminary ruling to the CJEU taking into account the Cilfit criteria. ${ }^{888}$ If so, the non-referral for a preliminary ruling could infringe the party's right to access to the court constituted by law guaranteed by Art. 23 of the Constitution. Namely, the court which corresponds to the court constituted by law (which is one of the guarantees of the right to judicial protection - the first paragraph of Art. 23 of the Constitution) could only be the CJEU. ${ }^{889}$ The Luxembourg court is that to which Slovenia has transferred the exercise of part of its sovereign rights, according to Art. 3.a of the Constitution. Hence only CJEU could be regarded as "the court constituted by law".

vii) Last, the CC's decision on the constitutionality of the provision of the Civil Procedure Act (hereinafter refreed to as the CPA) stipulating that it suffices for the reasoning of an order by which a motion for leave to appeal is dismissed that the Supreme Court makes general reference to the nonexistence of the conditions determined by Article 367a of this Act is also worth mentioning. ${ }^{890}$ In the latter the CC found petitions challenging the relevant statutory provision to be manifestly unfounded. It put forward that the purpose of the right to fair trial, which also includes the requirement to ensure appropriate reasoning of decisions, is to protects individuals in proceedings regarding their rights, obligations, and legal interests. Hence the assessment of to what extent the proceedings refer to the individual position of the party is an important factor which determines the scope of the protection of the right to appropriate reasoning. Deciding on granting leave to appeal is a sui generis preliminary procedure in which the Supreme Court reviews whether the case involves

\footnotetext{
887 See Regina Valutyte, State Liability for the Infringement of the Obligation to Refer for a Preliminary Ruling under the European Convention on Human Rights, Jurisprudencija/Jurisprudence, Vol. 39, No. 1 2012, p.11. See the cases cited therein: Societe Divagsa v. Spain (decision dated 12 May 1993); Peter Moosbrugger v. Austria (decision dated 25 January 2000); Canela Santiago v. Spain (decision dated 4 October 2001); Pedersen and Pedersen v. Denmark (decision dated 12 June 2003), Coëme and Others v. Belgium (decision dated 22 June 2000). The standard of arbitrariness is directly linked to the obligation to motivate the decisions, the ambit of which depends on the circumstances of each case and the arguments chosen by national courts in order to substantiate the non-referral (ibidem, p. 17).

888 Case No. 283/81, Cilfit and Others [1982] ECR 3415, para. 21

${ }^{889}$ Compare decisions of the German Federal Constitutional Court BVerGE 73, 339; 82, 159; 50, 287; 54, 86; 81, 97 etc. See Bodo Pieroth in Grundgesetz für die Bundesrepublik Deutschland Kommentar, (Jarass, Pieroth ed.), Verlag C. H. Beck, München 2011, p. 1029.

890 See CC Order Nos. U-I-302/09, Up-1472/09, U-I-139/10, Up-748/10, dated 12 May 2011.
} 
legal issues relevant to the legal order as a whole which go beyond the specific case and interests of the parties to the specific proceedings.

The decision as to whether a party's case involves legal issues relevant to the legal order as a whole entails only an insignificant degree of deciding on the party's "rights, obligations, and legal interests". What the constitutional procedural requirement to ensure appropriate reasoning is designed for protecting the individual position of a party (his or her right to know the reasons for a decision on his or her rights, obligations, or legal interests) - is not primary or decisive. This scope of individual protection corresponds to the degree of reasoning that is required under the challenged Article 367c of the CPA. In other words, it does not follow from the right to make statements and the right to a fair trial determined by Article 22 of the Constitution that the Supreme Court must provide a statement of reasons on the merits as to whether based on the criterion of public interest it will grant a legal remedy that human rights do not demand. From the standpoint of this procedural guarantee, it suffices that in its order the Supreme Court merely makes a general reference to the legal reasons for dismissing the leave to appeal. The established position of the ECtHR is essentially the same: in cases when the Supreme Court or the highest court in the state dismisses a motion by reasoning that there is no legal basis for such, the requirements determined by the first paragraph of Article 6 of the ECHR are satisfied even by a very limited statement of reasons. ${ }^{891}$ And this is not (only) because the requirement to provide a full statement of reasons for a mass of procedural orders that are virtually insignificant with regard to the legal order as a whole could undermine the capabilities of the Supreme Court due to the resulting excessive caseload. What is crucial is that manageability and clarity with regard to the number of cases are inherent to the nature of precedent, and that everything the precedent court states is understood as a precedent (even what it writes with regard to the merits in the order dismissing a leave to appeal).

The central role of courts of supreme jurisdiction is precedential (these courts bear responsibility to ensure the consistency of case law in a state, thereby guaranteeing equality before the law and ensuring the development of the law by means of case law) and thus focused on the protection of the public interest. The subjective dimension of an appeal, on a point of law, i.e. protecting parties' rights in specific disputes, is not primary; the principal manner in which courts of supreme jurisdiction protect particular interests of individuals is indirect, through the protection of the public interest. ${ }^{892}$ If so, the question may arise: should the ECtHR's case law on excessive length of proceedings before supreme courts and constitutional courts be reconsidered? Namely, those courts are designed as guardians of the public interest. They are not focused on the protection of individual rights in specific cases; this is what proceedings at the first and second instances are dedicated to. It is at the first and second instances that the human right to effective judicial protection (including the execution of court decisions) and the human right to legal remedies are implemented, and that is where the requirement to provide a statement of reasons on the merits in court decisions applies to its full extent. Does this entail that the right to a trial within a reasonable time should not be applied to proceedings before courts of supreme jurisdiction - or at least not in the same manner as to proceedings before lower courts? If the answer was positive, would the legal remedies before courts of supreme jurisdiction (which, as a matter of principle, should be exhausted before referring to the ECtHR) still be effective remedies?

${ }^{891}$ See, for example, the judgments in the cases of Nerva and others $v$. the United Kingdom, dated 11 July 2000 (the House of Lords Appeal Committee did not grant the right to a legal remedy with limited reasoning, by a decision implying that the case did not concern legal issues of fundamental importance), Ovlisen v. Denmark, dated 30 August 2006 (the Procesbevillingsnaevnet, i.e. the appeals committee, rejected a motion for the admissibility of an appeal against the decision of a higher court with the reasoning that the case did not deal with legal issues of fundamental importance), and Bachowski v. Poland, dated 2 November 2010 (the Supreme Court only stated the typical formulaic sentence in the reasoning). For similar in ECtHR case law, see A. Galič, Dostop do Vrhovnega sodišča v pravdnem postopku v novejši praksi ESČP [Recourse to the Supreme Court in Civil Procedure in Recent ECtHR Case-law], Pravna praksa, Nos. 6-7 (2011), pp. 7 et seq.

892 See M. Bobek, op. cit., pp. 62 and 63. 


\subsection{Civil rights}

The ECtHR's jurisprudence on civil rights had (and still has) a considerable influence on Slovene legislation and judicial practice and even on the functioning of the national executive branch of government. The aforementioned cases of Matko and Rehbock stimulated the Government to submit appropriate amendments of the Police Act and the Code of Criminal Procedure regarding the supervision of police activities. The case of Štrucl and others and the case of Mandić and Jović activated the governmental awareness of the conditions in Ljubljana prison - what resulted in tangible improvements therein. The case of Šilih influenced not only the jurisprudence, but also raised the general awareness of the importance of the state's duty to set up an effective independent judicial system so that the cause of death of patients in the care of the medical profession (and other persons who are in detention or otherwise under the control of the police or other state authorities - detainees and prisoners) is examined promptly and diligently. ${ }^{893}$ When reviewing provisions of the Non-litigious Civil Procedure Act, regulating the procedures for detaining persons in mental institutions, the CC considered the criteria established in the ECtHR's case of Winterwerp v. Netherlands (dated 24 October 1979). ${ }^{894}$ Since these criteria were not met, the challenged provisions were found to be contrary to the Constitution (CC Decision No. U-I-60/03, dated 4 December 2003). ${ }^{895}$

The Strasbourg case law was one of its main supports when the CC examined a number of provisions of the Religious Freedom Act (Decision No. U-I- 92/07, dated 15 April 2010). The CC referred to the cases of Campbell and Cosans v. the United Kingdom (judgment dated 25 February 1982) and Leela Förderkreis E. V. and Others V. Germany (judgment dated 6 November 2008), when arguing that religious or other beliefs enjoy protection under Article 41 of the Constitution (freedom of conscience) only if the internal and external characteristics of belief demonstrate its consistency, cogency, seriousness, cohesion, and importance. Further the CC held (by quoting the ECtHR's case law), that the constitutional protection encompasses only those actions which are reasonably related to the essence of the religious beliefs and without which the religious freedom of the individual would be significantly curtailed. Obligations and prohibitions of actions that do not meet this standard cannot constitute an interference with freedom of religion. ${ }^{896}$ The CC clearly established that religious groups are also the addressees of religious freedom. In this respect a reference was made to the ECtHR which emphasised in several decisions, inter alia, that religious communities traditionally exist in the form of organised structures and that their autonomous existence is an indispensable element of pluralism in a democratic society and thus an issue at the very heart of the protection which Article 9 of the ECHR guarantees. ${ }^{897}$ Finally the CC explicated the very essence of the principle of the separation of the state and religious communities. Its purpose "[...] is not [...] to protect the state itself from religious and other beliefs and associations (the state itself, of course if it

\footnotetext{
893 This assumption could be proved by the subsequent case of Volk v. Slovenia (13 December 2012), in which the ECtHR found that the authorities had investigated the applicant's son's death (during his imprisonment) with the diligence and promptness required under the procedural limb of Article 2 of the ECHR.

894 See para. 40.

${ }^{895}$ According to the ECtHR, involuntary commitment is only permissible if the mental disorder has been reliably demonstrated based on objective medical expertise, and if the patient's mental disorder is of such a kind or gravity as to make him or her an actual danger to himself or herself or to others. The third demand refers to the duration of commitment which may last only as long as the mental disorder justifying it persists.

${ }^{896}$ For example, the ECtHR did not consider the refusal of a pharmacist to sell contraceptive pills to be the exercise of religion or belief (the decision in the case of Pichon and Sajous v. France, dated 2 October 2001).

897 See, for example, the judgments in the cases of Cha'are Shalom Ve Tsedek v. France, dated 27 June 2000, and Hasan and Chaush v. Bulgaria, dated 26 October 2000. The ECtHR has repeatedly emphasised that the failure to recognise the legal personality of a religious community constitutes an interference with the freedom of religion determined in Article 9 of the ECHR (see the cases of Religionsgemeinschaft der Zeugen Jehovas and others v. Austria, judgement dated 31 July 2008, and Metropolitan Church of Bessarabia and others v. Moldova, judgement dated 13 Dec. 2001).
} 
is democratic, is not to be protected from anything), but to ensure complete freedom of conscience and the equality of all people, adherents and non-adherents, with its neutral stance." The CC continued: "Without this principle, encompassed in the freedom of conscience, this human right would be incomplete. It would be incomplete because there would be no effective tool for establishing freedom and equality for all. And, more importantly, without this principle the door would be open in the other direction - to the influence of the state on religious communities. The principle of separation is therefore not statist, but humanistic." 898

The ECtHR's case law has been extensively cited in all cases concerning the right to privacy. In one of its last decisions (the case concerned the right to privacy of legal persons) the CC referred to the Strasbourg case Société Colas Est and others v. France (judgement dated 16 April 2002), which seems to have had a weighty influence on the decision. ${ }^{899}$ Namely, the CC found support for its standpoint that the word "home" under Article 8 of the ECHR encompasses also the registered office of a company in the position of the ECtHR that "[...] the word 'domicile' (in the French version of Article 8) has a broader connotation than the word 'home' and may extend [...] to a professional person's office." Further the CC relied on the ECtHR's conclusion that the inspectors' wide power to conduct investigations of the premises of the applicant companies' head or branch offices, without any prior warrant being issued by a judge and without a senior police officer being present, in order to obtain and seize numerous documents containing evidence of unlawful agreements, cannot be regarded as strictly proportionate to the legitimate aims pursued.

The CC found that the decisive standpoint of the Supreme Court (on which the challenged judgement was based) that in police proceedings the police may obtain data which are part of the constitutionally protected communicational privacy without a court order was contrary to the Constitution. ${ }^{900}$ The CC referred, inter alia, to the ECtHR's case law, from which it follows that information on the telephone numbers dialled are considered an integral element of telephone communications..$^{901}$ Hence the release of that information to the police without the consent of the subscriber amounts to an interference with the right guaranteed by Article 8 of the Convention.

In case No. Up-2155/08 (Decision dated 1 October 2009) the CC reviewed the constitutionality of the standpoint of first instance court (on which the challenged judgment had been based) that the right to reverence is ensured to individuals already if they are enabled to visit a deceased's grave, whereas their distress, pain, and fury, which indicate that the event ${ }^{902}$ had upset them and that it had provoked a certain emotional reaction in them, did not seem to be of significance from the viewpoint of the right to reverence. The CC found that such substantive definition of the right to reverence is too narrow from the viewpoint of the requirements which derive from the right to privacy. As the complainants justifiably pointed out, a grave is not merely a place of physical proximity to the deceased. The right to reverence is not exhausted already with visitations to the grave, but it ensures relatives most of all the conviction that the deceased are resting in peace, the conviction that the inviolability of their mortal remains and their grave are being respected, the conviction that their passing is being respected, and that their wishes expressed during their life are respected. In this decision the CC extensively referred to the ECtHR's case law. The Strasbourg Court underlines that certain events in the life of a family must be given particularly careful protection. The death of a close

\footnotetext{
898 See the par. 102 of the abovementioned decision. The CC clearly took the position of the liberal (American) model of separation which is based on the idea of the liberation of the church from the state with the intent to provide space for religious freedom. See Christian Walter, Religionsverfassungsrecht [Constitutional Law of Religion], Mohr Siebeck, Tübingen 2006, p. 69.

899 Decision No. U-I-40/12, dated 11 April 2013.

900 Decision No. Up-106/05, dated 2 October 2008.

901 See the case of Malone v. the United Kingdom, judgement dated 2 August 1984; see also the case of $P$. G. and J. H. v. United Kingdom, judgement dated 25 September 2001.

902 In order to arrange the cemetery the municipal utility company had moved the urn grave of their parents (by $20 \mathrm{~cm}$ ) without their knowledge and consent, and even against their deceased father's will,
} 
relative and the ensuing mourning must lead the authorities to take the necessary measures to ensure that the private and family lives of the persons concerned are respected. ${ }^{903}$ The ECtHR established a violation of Article 8 of the Convention in a case in which the competent authorities refused to allow the then detained applicant to leave detention to attend the funerals of his parents; ${ }^{904}$ in a case in which the authorities did not return the body of a girl who had died in hospital to her parents due to the inquiry for seven months; ${ }^{905}$ and in a case in which the competent authorities, without notifying the parents of a stillborn baby, took the baby's body in an inappropriate vehicle to the cemetery and buried the baby in a communal grave. ${ }^{906}$

In case No. U-I-30/12 (dated 18 October 2012) the CC ruled that the right to know one's own origin, deriving from the protection of the right to privacy and personality rights (Article 35 of the Constitution) does not cease to exist after the death of one's alleged father. Therefore the imposition of a preclusive time limit for a child to file a legal action for the post-mortem determination of paternity entails an interference with the child's personality right to know his or her origin. The CC's standpoint is supported by the Strasbourg case of Jäggi v. Switzerland (judgment dated 13 July 2006). In weighing the applicant's right to establish who his father was by means of a DNA analysis of a DNA sample of his deceased father, on the one hand, and the right of relatives to the inviolability of the deceased's body and the right to respect for the dead, on the other, the ECtHR tipped the scales in favour of the right to establish one's fatherhood.

The ECtHR's case law is considered to be an inevitable guidance for the Slovene judiciary when searching and establishing the proper balance between competing human rights, thus for resolving conflicts arising from the horizontal effect of fundamental rights; for example conflicts between the freedom of expression on one side and the right on privacy (or the right to dignity) on the other. In such cases so-called "multi-polar" fundamental rights constellations are involved and as a consequence courts usually have to balance conflicting fundamental rights positions, using practical concordance as a tool and jurisprudence of (the CC and) the ECtHR as an argumentative expedient. In one of its recent decisions the CC weighed the right of the plaintiffs to privacy and the confidentiality of written communications, on one side, and the right of a book's author and the publishing house to freedom of expression, on the other. ${ }^{907}$ On the basis of the weighing or balancing of both, the court establishes a rule regarding the coexistence of both rights, stipulating which of them should be given priority in the circumstances of the case at issue. From the viewpoint of constitutionality, it is essential that neither of the human rights is excluded from consideration by the court. In the assessment or weighing, the court must not disregard constitutionally decisive circumstances. In this (and in similar) case(s) references were made to exhaustive Strasbourg case law on this matter. However, some embarrassment may occur in this respect, due to the principle of the highest level of protection (the fifth paragraph of Article 15 of the Constitution). From this point of view it could become contestable whether the ECtHR's case law could always serve as a considerable fingerpost for determining which circumstances are decisive and how much weight should be assigned to each of the conflicting rights respectively.

\footnotetext{
${ }^{903}$ See the case of Hachette Filipacchi Associes v. France, judgment dated 14 June 2007.

${ }^{904}$ See the case of Płoski v. Poland, judgment dated 12 November 2002.

905 See the case of Pannullo and Forte v. France, judgment dated 30 October 2001.

906 See the case of Hadri-Vionnet v. Switzerland, judgment dated 14 February 2008.

907 Case No. Up-444/09 (Decision dated 12 April 2012). In another recent case (Decision No. Up-570/09, dated 2 February 2012) the CC assessed that the Higher Court (which by its decision had protected the complainant's right to the protection of privacy and personality rights) had not established a proper balance between the right of the plaintiff and the right of the complainants - a journalist and a newspaper company - to freedom of expression. The CC concluded that by the adopted standpoints the Higher Court had unjustifiably limited the leeway of the journalist and the newspaper to report about a topic of high public interest. Thereby it had inadmissibly interfered with the constitutionally protected core of the complainants' right to freedom of expression. In both cases the CC extensively cited the ECtHR's case law.
} 


\section{Has the case law in relation to the country influenced the Court's case law more broadly and in what manner?}

As previously stated, Slovenia is one of the states infamous for being convicted for violating the right to a trial within a reasonable time. Therefore the ECtHR's case law in relation to Slovenia mainly influenced the Court's case law exactly in this respect. The vast majority of "Slovene" cases cited in Strasbourg jurisprudence fall under the first paragraph of Article 6 of the Convention. The case Lukenda for example has been cited in more than 30 cases, all classified in the group of cases of high importance, and six of them have been included in the Case Reports. The next group of cases in which case law in relation to Slovenia was cited, belongs to the cases regarding the prohibition of torture. The prominent position in this group belongs to the cases Rehbock and Matko; the former has been cited in six and the latter in three cases classified in the Case Reports. The case Šilih (concerning the procedural limb of the right to life) can be found in four cases published in the Case Reports. However none of these cases, even though frequently cited, had a decisive and broad impact on the development of the ECtHR's case law. Furthermore only four cases in relation to Slovenia, namely the cases Kurić and others, Mamić, ${ }^{908}$ Lukenda and Rehbock have been classified in the Case Reports.

\section{Conclusions}

Due to the principle of the highest extent of human rights protection, as set forth in the fifth paragraph of Article 15 of the Constitution, the ECHR has become a sort of "Shadow Constitution". ${ }^{909}$ Hence the ECtHR plays the role of a "Shadow Constitutional Court", explicitly through the pilot procedure. At first glance this seems very promising; namely, Individuals may turn to two supreme guardians for the protection of their human rights - one on the national level and one on the international. Moreover, as ordinary courts are bound by national Constitutions and thus turned into miniature constitutional tribunals, ${ }^{910}$ the number of such guardians became multiple. However, the insight into the empirical substance of the life of human rights is less promising. The problem (and the bad luck for the values protected by human rights) arose from their inception, i.e. from the moment when the ethical values prior exclusively belonging to the world of ethics (based on the assumption of the reasonableness of human beings and their capability to act as moral agents) have lost their innocence. This is the moment when they entered the magic (and prescriptive) circle of the Law.

What is coming to pass from then on is well known, especially in the age of human rights. Almost all fields of law have been constitutionalized - what is a good news for the law (and much better for the parties in proceedings and their lawyers) and not so good news for the ethical values inherent in the rights (and thus in the law). Since law is nothing but a mere substitute for rude physical power as a criterion for the resolution of disputes between members of a certain community (i.e. "rational egoists"), it is likely to be manipulated. The dispute will be won by the one (as law is a substitute for rude power, not who has a better weapon but) who has better legal arguments, to be precise, the one who is better in argumentation manoeuvring. It has been stated previously, how human rights are nowadays (ab)used as means for attaining certain tangible and at times selfish interests, far from

\footnotetext{
908 In the case of Mamić v. Slovenia, judgement dated 27 July 2006, the ECtHR found that the proceedings did not disclose periods of inactivity such as to render them incompatible with the first paragraph of Article 6 of the Convention. Nor did the overall length of the proceedings infringe the reasonableness requirement of that provision. However the Court considered that there had been a violation of Article 13 on account of the lack of a remedy under domestic law whereby the applicant could obtain a ruling on whether her case had been heard within a reasonable time.

$909 \mathrm{H}$. Keller and A. Stone-Sweet, A Europe of Rights: The Impact of the ECHR on National Legal Systems, Oxford University Press, Oxford 2008, p. 686.

910 See M. Bobek, op. cit., p. 59.
} 
the intrinsic Conventional values. Values imbedded in human rights are not treated as values and ends per se; rather they are a mere expedient (although significant, if not decisive), which is manipulated for achieving the final goal, that is winning the case. A dilution effect on human rights and on the values which stand behind them is becoming obvious: at the end in the constantly increasing case load of the highest guardians of human rights - including the ECtHR.

As long as the ECtHR operates as a discoverer of new aspects of human rights, corresponding to certain individual interests, as long as the rights and duties under the ECHR are stretched to an extent that de facto new norms are "discovered", invented or created, ${ }^{911}$ as long as the Court performs the role of a fine tuner (term belongs to W. Sadurski), operating on the periphery of the rights, until then the Court will be flooded with cases. And consequently a huge number of judgements will be delivered. The ECtHR is a precedential court bearing special responsibility with regard to the development of case law. Its role is jeopardised not just if it delivers too few decisions, but also - just as effectively, albeit not as obviously at first glance - by an overproduction of case law. What is crucial is that manageability and clarity with regard to the number of cases are inherent to the nature of precedent, and that everything the precedent court states is understood as a precedent. Only if the number of cases is manageable and it is possible to maintain an overview in terms of substance, is it reasonable to expect that the cases will indeed serve as ex ante guidelines for national courts and addressees of Conventional norms in general. The precedential dimension of the ECtHR's mission could actually be undermined and its position would be weakened by a huge influx of cases and consequently the sheer volume of judgements delivered. Or, as L. Wildhaber addressed this problem: "Is it not better for there to be fewer judgments, but promptly delivered and extensively reasoned ones which establish the jurisprudential principles with a compelling clarity that will render them de facto binding erga omnes? At the same time they would reveal the structural problems which undermine democracy and the rule of law in parts of Europe." ${ }^{12}$ That is to say: less is more. However, how could the ECtHR meet this end?

It is hard to disagree with calls for the return to the primary role of the Court: safeguarding the core of common European values. If less is more, than the fundamentals are more, while the glass bead game approach is less. On the one hand, the Court has taken an over-detailed and over-minutious approach in weighing competing rights, for instance the right to privacy and freedom of expression, ${ }^{913}$ while on the other hand, relying on its doctrine of dynamic interpretation of the Convention, the

\footnotetext{
911 See J. Gerards, op. cit., p. 186.

912 L. Wildhaber, The European Court of Human Rights in action, Ritsumeikan Law Review, Vol. 2 (2004), No. 21, p. 92.
}

111 In this respect see one of the most cited and discussed cases in this category Von Hannover v. Germany, dated 24 June 2004

112 See for example the case of Gross v. Switzerland (judgement dated 14 May 2013), where the Court characteristically demonstrated its incremental, case by case approach which resulted in the highly contestable conclusion that "Swiss law, while providing the possibility of obtaining a lethal dose of sodium pentobarbital on medical prescription, does not provide sufficient guidelines ensuring clarity as to the extent of this right" and thus violated the applicant's right to private life. The main reproach to the Swiss law was that the absence of clear and comprehensive legal guidelines on whether and under which circumstances an individual in the applicant's situation - that is, someone not suffering from a terminal illness - should be granted the ability to acquire a lethal dose of medication allowing them to end their life. However, as underlined in the joint dissent, the Federal Supreme Court's case-law, which refers to medical guidelines, sufficiently and clearly defines the circumstances under which a medical practitioner is allowed to issue a prescription for a lethal dose of sodium pentobarbital. See also the case of Société Colas Est and others v. France (judgement dated 16 April 2002) wherein, "[b]uilding on its dynamic interpretation of the Convention, the Court considers that the time has come to hold that in certain circumstances the rights guaranteed by Article 8 of the Convention may be construed as including the right to respect for a company's registered office, branches or other business premises." Several other similar cases could be mentioned, e.g. Stec and others v. United Kingdom (judgement dated 12 April 2006), Hirst v. United Kingdom (judgement dated 6 October 2005) etc. 
Court discovers new interests protected by Conventional (and thus, from the Slovene perspective, constitutional) rights. ${ }^{914}$

When there is a collision of two human rights, the content of both rights must be restricted. The assessment of whether the exercise of one right already excessively restricts the exercise of the other right requires a value-based weighing of the meaning of both rights against the weight of the interference. Therefore, in cases of horizontal effect of human rights the Court should exercise more self-restraint and limit its intervention only to fundamental cases - that is cases in which one of the conflicting rights was disregarded or cases in which the national court failed to balance conflicting fundamental rights positions. However, when the national court took into consideration each of the competing rights, applied the law of balancing and hence found a practical concordance between the rights in conflict, then, irrespective of the particular outcome, the Court should not enter into a detailed review of the final decision, even if it reflects a different balance or even if a different weight was assigned to the respective conflicting rights than the Court would have preferred. What is essential in this respect is that neither of the human rights has been excluded from consideration by the Court. In addition, in cases of conflicting rights positions neither of the two rights could be exercised to its full extent; hence restrictions are inherent to fundamental rights in their horizontal relations. Proportionality (as a result of balancing) includes mutual limitations - one right is given priority on account of another. If this is connected with the principle of the highest level of protection (the fifth paragraph of Articel 15 of the Constitution), a problem may occur if a national court gives priority to one right, while the ECtHR's case law favoured another.

As regards dynamic interpretation of the Convention, the Court should always bear in mind that its decisions, regardless of how they are treated by the respective states, at least yield a considerable message all over Europe, from Reykjavik to Vladivostok (the expression belongs to B. M. Zupančič), on how the Convention should be understood in similar factual circumstances and thus establishing a fundamental moral order in all member states. By limiting its activity by the common ethical denomination throughout Europe the Court will focus on cases that truly concern basic values underlying the Convention and emanating its spirit and hence uphold the ECHR's core standards and put into force its values as ends in themselves; the proactive nature of human rights should be based on Kant's common denominations, thus on some kind of categorical imperatives: that is on prescriptive norms assumed as being essential and absolutely fundamental for human dignity. ${ }^{915}$ If for anybody, it is for the ECtHR to demonstrate that human rights law is much more than formal logic and the glass bead game. Or in the words of Leonid Pitamic, a giant of Slovene legal thought: "We will not create, we will not share, and we will not find justice, if there is no justice inside us!"916

\footnotetext{
[space between two footnotes]

915 See B. M. Zupančič, Dignity, Anomy...and the Future of Human Rights [Dostojanstvo, anomija...in prihodnost človekovih pravic], Revus, Vol. 10, November 2009, p. 29.

916 L. Pitamic, Pravo in revolucija [Law and revolution], Zbirka političnih, gospodarskih in socialnih spisov, Vol. V., Tiskovna zadruga, Ljubljana 1920, p. 23.
} 


\title{
UKRAINE
}

\author{
Ganna Yudkivska*
}

\section{Ukraine on the Way to Democracy Role and Achievements of The European Court Of Human Rights}

\section{Introduction}

Some ten years ago, in 2004, as a practicing lawyer I applied to the Court requesting an interim measure under Rule 39 of the Rules of the Court in an extradition case. The measure was granted and that was the very first application of Rule 39 in Ukraine. It struck both prosecuting authorities and judges, who could hardly imagine that the European Court of Human Rights, still considered that time to be more extraterrestrial than a part of a real legal system, could interfere in the middle of the process and upset applecart. Lawyers did not know much about the Convention and its mechanisms either; we were learning and trying to bring changes.

Over past years the situation has changed dramatically. Today the European Court of Human Rights is tremendously popular and well-known even in the most remote Ukrainian villages. Its judgments are disseminated and widely discussed both by professionals and non-lawyers. Ukrainian lawyers refer to the Convention and the Court's case-law in their pleadings before courts and in procedural documents; accordingly, Ukrainian judges quote the Court's judgments all the more (although not always in a fully satisfactory way - as will be argued below). It means that Ukrainian judges nowadays feel themselves as a part of the European judicial system; they are ready, willing and able to "borrow" legal approaches of their European colleagues and to adopt their views on human rights matters.

Political and legislative processes are much slower. Dialog between Strasbourg and Kyiv has its successes and defeats which I'll try to address below.

Ukraine passes now through an extremely difficult period in its history. I have drafted this article at the time when following a national rebellion, well-known today as "the EuroMaidan protests", my country lost more than hundred its sons and daughters; and unfortunately the war is not yet over and deep crisis is still far from being overcome.

The EuroMaidan was triggered firstly by the government's decision not to integrate into the European community with its high democratic standards, and then - to a much larger extent - by violent attempts to scatter peaceful demonstration on 30 November 2013, when for the first time in the Independent Ukraine blood was spilled by police. Ukrainians realized that brutal violations of the core human rights had reached their limits, and the desire to see the Human Rights treaties more than a scrap of paper brought the next morning about half of million people to the Kyiv central square. That became already a point of no return, and subsequent passage of legislation restricting the most valued freedom for the civil society - freedom of assembly and association - acted as a further catalyst.

The peaceful protest which turned into a violent conflict solidated the nation - during about three months hundreds of thousands of people came to the streets to protect precisely the values promoted and shared by the European Community and safeguarded by the European Court of Human Rights. And the Court is much-in-demand by Ukrainians who become more preserving in struggling for their right to live in the State adherent of rule of law.

These days the Court receives a record number of new applications against Ukraine (only in January 2014 we have got 2,600 new cases). A relatively recent trend of significant decrease of people's trust 
in the domestic judicial system on the one hand, and growing acquaintance of their rights on the other hand, generate an inspiration to look for a fairness outside the framework of the internal legal system. However, this unshakeable faith in the European justice is combined with lack of sufficient knowledge of the Court's competence and procedure, thus numerous applications are declared inadmissible already by a single judge, in accordance with a procedure introduced by Protocol No. 14 to the Convention (for example, out of 15,245 new applications against Ukraine received by the Court in 2013, 7,765 were declared inadmissible in a single judge formation). Many legal problems have an endemic nature thus bringing many so-called "clone cases" to the Court, which will be mentioned below.

But many complicated legal problems coupled with increased perception of rights and freedoms and a desire to struggle for them, encourage Ukrainians to bring new important cases to the Court.

\section{Historical aspects of the accession of Ukraine at the European Convention on Human Rights}

Ukraine signed the European Convention on Human Rights in November 1995. The Convention then entered into force with respect to Ukraine in September 1997. The very first cases against Ukraine, examined by the Commission, concerned detention conditions in a death row. In November 1998 the Commission carried out a fact-finding visit to Ukraine in this respect, and almost a year later, in October 1999 it expressed the opinion that there had been a violation of Article 3 as a result of the conditions of the applicant's detention there, and also a violation of Article 8 and Article 9 (concerning family visits and visits by a priest for sentenced to a death penalty). A month after, in November 1999, the death penalty was abolished in Ukraine.

Since that time, for past 15 years, around 900 judgments were given in cases against Ukraine, and more than 30,000 applications were declared inadmissible by different Court formations, about 1000 applications were struck down following a reached friendly settlement or accepted unilateral declaration by the Government.

It is noteworthy that the Constitution of Independent Ukraine was drafted at the time of active negotiations with the Council of Europe concerning the membership. The Constitution was adopted in June 1996, about seven months after Ukraine signed the European Convention. Thus many of its provisions on human rights and freedoms were drafted in conformity with the Convention. The Constitutional Court of Ukraine, for instance, in its landmark judgment on abolishment of death penalty mentioned that Article 28 of the Constitution according to which "no one shall be subjected to torture or to inhuman or degrading treatment or punishment" merely "reproduce[d] Article 3 of the European Convention on Human Rights of 1950"917.

Obviously, application of the Convention and the Court's case-law in Ukraine raises a more general issue on relationship between international and national legal norms in Ukrainian legal system.

The Ukrainian Constitution implements a monistic approach and considers the international agreements ratified by the Verkhovna Rada (Ukrainian parliament) as an integral part of national legislation. According to Article 9 of the Constitution, "[i]nternational treaties in force, consented by the Verkhovna Rada of Ukraine as binding, shall be an integral part of the national legislation of Ukraine".

Further, according to Article 19 of the Law on International Agreements of Ukraine, "Current international agreements of Ukraine, the binding nature of which has been ratified by the Verkhovna Rada of Ukraine, are a part of domestic legislation and shall be applied under the procedure provided for the norms of domestic legislation". As concerns correlation between international

917 Decision no. 11-pп/99 of 29 December 1999. 
agreements (ratified by the Verkhovna Rada) and domestic legislation the same Article provides as follows:

[i]f the international agreement of Ukraine, which has come into force under the set procedure, sets rules other than those envisaged in the respective act of Ukrainian legislation, the rules of international agreement shall apply.

Thus it is clear that in case of a discrepancy between a ratified international treaty and domestic legislation (except for the Constitution), the former will prevail.

However, Ukrainian scholars note that whilst the Ukrainian legal doctrine is based on the priority of international law over domestic one, the situation in practice is different. In particular, the procedure for application of ratified international treaties by courts is not clearly defined in the national legislation. ${ }^{918}$.

\section{Mechanisms of implementation of the Convention}

\subsection{Law on the Enforcement of Judgments and Application of Practice of the European Court of Human Rights}

In 2006 the Ukrainian Parliament adopted the Law on the Enforcement of Judgments and Application of Practice of the European Court of Human Rights (hereinafter - "the Law on Enforcement"), which was highly appreciated at the international level as one of the best examples of application of the Convention in the national legal systems. This law became a revolutionary contribution into the issue of implementation of the Convention at a national level. It also embodied majority of relevant recommendations of the Committee of Ministers of the Council of Europe concerning execution of the Court's judgments.

Since this Law on Enforcement plays a vital role in implementing the Convention's standards in Ukraine I'll dwell upon it. I must say at the outset that, unfortunately, its most progressive provisions were well in advance of their time and thus cannot be fully implemented.

One can assume that the most valued provision of the Law on Enforcement is Article 17, which provides that "courts shall apply case-law of the ECtHR as a source of law". Due to this provision the Law was highly appreciated by different bodies of the Council of Europe. Despite disagreement by many legal scholars on such legislative recognition of the Court's law-making function, today the very principle that national courts should rely on judgments of the Court does not raise the same sharp discussions as previously. Regrettably, nevertheless, the above provision serves more a vector of development of domestic courts' practice rather than an enforceable legal norm. In order to fully enforce it, our judges should sufficiently know the Court's case-law, and should follow its development. Needless to say that their workload and linguistic barrier do not allow them to learn it to a necessary extent. Numerous seminars and conferences, of course, make their contribution, but their effect is still insufficient. Thus among several thousand judgments of national courts, which according to the database ${ }^{919}$ contain reference to this Article 17 - application of the Court's case-law as the source of law -, only in several judgments there is a deep analysis of a certain Convention provision and the Court's case-law. The remainder only contains a general reference to the most famous translated judgments, factual circumstances of which quite often do not correspond to factual circumstances of a case at stake (for example, a rare case concerning the limits of free speech in connection with criticism of public figures gets along without mentioning the textbook precedent of Lingens $v$. Austria, which is often inappropriate in the circumstances of the case).

\footnotetext{
918 See, for example, O. Butkevich, "Ukrainian case-law and the legal standards of the European Court of Human Rights" in "Law of Ukraine", no. 5-6, 2011.

919 www.reyestr.court.gov.ua
} 
Former President of the Supreme Court of Ukraine, Mr Vasyl Onopenko, pointed in this respect:

"In many cases, when applying the practice of the European Court, courts have no precise and unambiguous notion of the legal substance of such application. For this reason, the activities of Ukrainian courts often manifest abstract references to the practice of the European Court without indicating the specific decisions of this institution.

At times it happens the other way around - decisions of Ukrainian courts refer to specific decisions of the European Court but do not indicate their correlation with the norms of national law and the circumstances of a specific case" 920 .

Again, the situation is changing now and, as mentioned above, Ukrainian judges feel now much more comfortable in application of the Convention than even several years ago.

Further, Article 18 of the Law on Enforcement, which obliges to use either official translation or original text, creates significant difficulties - there are not so many judgments published in official editions (in fact, the Law binds the Ministry of Justice to translate and publish only judgments against Ukraine); and it would be quite unrealistic to rely on Ukrainian judges' fluent knowledge of the Court's official languages. It is even more unrealistic to imagine English- or French-language quotations in a judgement of Ukrainian court.

Another ambitious provision of the Law concerns an obligation imposed on a Governmental Agent to analyze, in each case, circumstances which led to a violation found, and to undertake necessary measures to eliminate the systemic or structural problems. There is no information on how this provision works. In principle, the part of the Law on Enforcement which deals with general measures to be implemented following the Court's judgments is also far from being fully realized. A timely response to the existing structural problems in legislation and practice, as pointed by the Court, would allow not only to avoid clone applications to Strasbourg and pilot judgments, but also to restore health of the Ukrainian legal system.

Nevertheless, despite all practical deficiencies of this Law, it demonstrates a strong desire of the State to implement the human rights standards as developed by the Court's jurisprudence.

\subsection{Executive level}

The Ukrainian Government closely cooperates with international bodies which pay significant attention to the issue of implementation of the Court's case-law in Ukraine.

Thus, the Council of Europe Action Plan for Ukraine for 2008 - 2011 stated that "Ukraine is one of the countries with the highest number of applications to the ECtHR and the capacity to implement the Convention must be strengthened. Efforts to train key professional groups on the ECHR must be continued. Judges, prosecutors, lawyers, law enforcement officials, NGOs, staff of the Ombudsman and the Government Agent for the ECtHR, and staff of penitentiary institutions should be further trained on ECHR standards and ECtHR case law". 200,000 euros were allocated with the aim of "expert support to national structures, NGOs and civil society within three broad areas of CoE competence: Human Rights training; Human Rights education and awareness-raising in European human rights standards" ${ }^{\prime 921}$.

Action plan for 2011-2014 mentions, as the specific objectives, strengthening the capacity of the judiciary and the Government Agent's Office; raising awareness and disseminating knowledge on the Convention and case law in respect of Ukraine to national authorities and the judiciary, training judges, prosecutors, legal professionals, law enforcement agencies and prison staff ${ }^{922}$.

${ }^{920}$ V. Onopenko, "Mechanism for the protection of human rights in Ukraine requires significant improvement" in "Law of Ukraine", no. 5-6, 2011.

${ }^{921} \mathrm{https}: / /$ wcd.coe.int/ViewDoc.jsp?id=1317485

922http://hub.coe.int/c/document_library/get_file?uuid=24875c00-6299-4c4f-9bd5-

ad47a56d5fle\&groupId=10227http://hub.coe.int/c/document_library/get_file?uuid=24875c00-6299-4c4f-9bd5- 
As concerns EU level, it is stated in the operational part of the EU-Ukraine Association Agenda adopted by the EU-Ukraine Cooperation Council on 23 November 2009 that "[t]he Parties agree to maintain dialogue ...[which]... shall cover ...following up on the implementation of the judgments of the European Court of Human Rights and promoting the evolving jurisprudence of the Court as a major source of international human rights law, with the support of the EU".

In February 2013 the Cabinet of Ministers of Ukraine issued an Action Plan on integration of Ukraine in the European Union for 2013, in which it undertook, "in order to deepen cooperation on justice, freedom and security... to ensure proper execution of judgments of the European Court of Human Rights against Ukraine in terms of individual and general approaches and, if necessary, submit appropriate proposals..."

Reference to the case-law of the European Court of Human Rights is made in the "Concept of the State Target Program of formation of the legal aid system for 2013-2017"923. Describing the problem that is to be solved by the Program, the Government noted that "[r]egardless international and constitutional obligations of Ukraine, the practice of free legal assistance remains unsatisfactory which leads to numerous judgments of the European Court of human rights against Ukraine on violation of the Convention, namely right to a fair trial..."

In this respect it worth mentioning that in the case of Savitskyy v. Ukraine ${ }^{924}$, which concerned torture that led to severe disability of the applicant, the Court decided that in the particular circumstances of the case (the applicant, being fully handicapped, could not move unaided and required permanent assistance) "the State's procedural obligations to ensure the effective participation of the victim in the investigation of his complaints of ill-treatment extended to the issues of providing effective access to free legal representation". The Court criticized the State since "the domestic law does not provide for legal-aid schemes which would apply to the applicant's situation". At the same time, it appears that the Free Legal Assistance Act of Ukraine of 2 June 2011 addressed the mentioned problem.

\subsection{Individual remedies}

Rehearing of the case remains the most effective redress for a violation of a right to a fair trial following relevant judgment of the Court. Although in many European countries such a possibility exists in quite a limited way, Ukraine has made all necessary changes in its procedural legislation already in 2001 in the course of so-called "petty judicial reform". Hence, the Code of Civil Procedure and Code of Commercial Procedure were amended with establishment of a new ground for rehearing of a case - if a judgment by an international court, whose jurisdiction is recognised by the Ukraine, acknowledges that a relevant court decision violates Ukraine's international obligations (similar amendment to the Code of Criminal Procedure was introduced much later, in 2010). The Code of Administrative Justice, which created a separate branch of administrative jurisdiction in Ukraine, entered in force in 2005 and already contained an analogous provision.

Further judicial reform in 2010 kept this possibility of review of a case following the Court's judgment unchanged for all types of cases. Therefore, in some cases against Ukraine the Court has specified under Article 41 that it is "indispensable for the proper protection of human rights that a retrial (a possibility of which is envisaged in the Ukrainian legislation) be provided forthwith should the applicant so request" ${ }^{\prime \prime 25}$.

ad47a56d5fle\&groupId $=10227$

${ }_{923}$ As adopted by the Cabinet of Ministers on 4 July 2012.

924 no. 38773/05, 26 July 2012.

${ }^{925}$ See, for instance, Nechiporuk and Yonkalo v. Ukraine, no. 42310/04, § 297, 21 April 2011. 


\section{The Court's case-law in respect of Ukraine and its effect on national legal order}

\subsection{Pilot Cases}

Up to the present moment the Court relied on Article 46 of the Convention, i.e. revealed systemic dysfunctions, in cases against Ukraine seven times. These judgments deserve mentioning.

\subsubsection{Non-enforcement of final judicial decisions}

The first Court's pilot judgment against Ukraine in the case of Yuriy Nikolayevich Ivanov v. Ukraine $e^{926}$ concerned the issue of prolonged non-enforcement of domestic decisions and lack of effective remedies in this respect. The Court noted that the enforcement of the judgments in the applicant's favour was hindered by a combination of factors, including the lack of budgetary allocations, the bailiffs' omissions and the shortcomings in the national legislation.

This judgment was delivered in 2009, but already 5 years before - in 2004 - in the case of Voytenko $v$. Ukraine $^{927}$ the Court found that there was no effective remedy in Ukraine against lengthy nonenforcement of final judgments, contrary to requirements of the Convention. The Court repeated the same conclusion in many other cases, but nothing was done at the national level to address the problem, so Ukraine came up with a pilot judgment, which likewise, unfortunately was not fully enforced despite it became final already four years ago. This situation, as stated by the Committee of Ministers, "poses a serious threat to the respect of the rule of law and to the effectiveness of the Convention system"928.

Having previously granted the Government an extension for execution of the pilot judgment and thus apparently not examining follow-up cases, in February 2012, in light of the failure of the Ukrainian Government to adopt the required measures, the Court resumed the examination of all cases covered by that judgment. Already in July 2012 the Court adopted the first grouped judgment disposing of 116 cases $^{929}$. By the end of 2013, about 2,900 so-called "Ivanov-type cases" were disposed in the same way.

However, despite the Court's efficiency in handling the Ivanov-type cases, the number of new applications introduced against Ukraine has been increasing radically, particularly in the last few months.

This Court's efficiency has not gone unnoticed at home. Out of 15,245 new applications against Ukraine received by the Court in 2013 approximately 40\% were of "Ivanov-type", marking 300\% increase compared to the previous year. That shows not only that the reasons led to the endemic nature of the problem at national level did not disappear, but also that those Ukrainians, whose judgments remained unenforced, realized that the only way to achieve enforcement within a reasonable period of time would be to apply to this Court.

In June 2012 the Parliament of Ukraine adopted a new "Law on State Guarantees with regard to enforcement of the judicial decisions", which entered in force in 2013 and was amended on two occasions. This Law introduced a procedure by which the debts under the domestic courts judgments were to be paid by the State Treasury of Ukraine if the creditors apply to the State Treasury according to a prescribed procedure.

\footnotetext{
926 no. 40450/04, 15 October 2009.

927 no. 18966/02, 29 June 2004.

928 Interim Resolution CM/ResDH(2012)234.

${ }^{929}$ see Kharuk and others v. Ukraine, no. 703/05, 26 July 2012.
} 
Nevertheless, as from the end of 2013 the Court has received a number of applications concerning the refusal of the State Bailiffs and the State Treasury to enforce the domestic judgments and to pay relevant debts. Therefore, it will be up to the Court in a very near future to examine adequacy of this remedy in terms of its ability to cure the systemic dysfunction.

\subsubsection{Problematic aspects of Criminal Procedure}

Many judgments issued against Ukraine concerned different aspects of procedural guarantees of accused and suspects; some of them derive from deficient legal norms, others are result of administrative practice. Undoubtedly, it's impossible to eliminate immediately a source of a violation of the Convention if it originates in well-established vicious practice. On the other hand a lot of systemic violations found in judgments against Ukraine were due to lacunas in legislation. Thus, in the quasi-pilot case Kharchenko v. Ukraine ${ }^{930}$, the Court said that "it regularly found violations of Article 5 of the Convention as to the periods of detention not covered by any court order; and the court orders made during the trial stage which fix no time-limits for further detention, therefore upholding rather than extending detention, which is not compatible with the requirements of Article 5. Both issues seem to stem from legislative lacunae».

Similar violations the Court had been finding in cases against Ukraine during several years, but as nothing was done by the national authorities in the mentioned case of Kharchenko the Court requested the Government to submit within six months the strategy adopted in this respect.

The Government provided the Committee of Ministers with the detailed analysis of a preventive detention procedure envisaged by the new Code of Criminal Procedure, which entered in force in November 2012. It was stressed, in particular, that the Code resolves the long-standing issue under Article $5 \S 1$ of the Convention concerning unauthorised detention not covered by the court decision (in particular, between completion of pre-trial investigation and beginning of trial procedure, while defendants were kept in custody solely on the basis of the fact that a bill of indictment has been submitted to the trial court). The Government claimed that the new procedure "ensure[d] the absence of periods of unauthorized detention a contrario the previous Code" ${ }^{\prime \prime 31}$.

However, the new applications received by the Court after the new Code entered into force, dispelled an illusion that the long-standing flawed traditions in criminal procedure could be easily eliminated within a short period of time following legislative changes.

In September 2013 the Court communicated to the Ukrainian Government a new application concerning the same issue of pre-trial detention without any court order during the period between the end of investigation and beginning of trial in February-April 2013, i.e. when the provisions of the new Code were already applicable ${ }^{932}$.

The very fact that this new case was urgently communicated to the Government demonstrates, that the reform of legal system by means of the Convention mechanisms is a two-ways street, and the Court is always ready to assist the State, pointing at systemic shortcomings and adequacy of their rectification.

Other problematic aspects of criminal procedure, criticised by the Court over past years, were:

(a) the general practice of unregistered detention by the police; the general practice of using administrative arrest for criminal investigation purposes without safeguarding the detainee's

\footnotetext{
930 no. 40107/02, 10 February 2011.

931 Communication from Ukraine concerning the case of Kharchenko v. Ukraine (Application No. 40107/02). https://wcd.coe.int/com.instranet.InstraServlet?command=com.instranet.CmdBlobGet\&Instranet/mage=2246 320\&SecMode $=1 \&$ Docld $=1984292 \&$ Usage $=2$

${ }^{932}$ See communication report in the case of Yuriy Vasylyovych Chanyev v. Ukraine, no. 46193/13.
} 
procedural rights, in particular the right to a defence; failure to state the grounds when authorising detention on remand and to set a time-limit for such detention (Article $5 \S 1$ );

(b) failure to bring the arrested person before a judge promptly; failure to advance relevant and sufficient grounds for extending detention on remand as well as to consider any alternative preventive measure (Article $5 \S 3$ );

(c) lack of a clear procedure in Ukrainian legislation which would allow speedy and due review of the lawfulness of detention on remand (Article $5 \S 4$ ); and

(d) lack of a remedy in Ukrainian legislation capable of providing compensation for the aforementioned breaches (Article $5 \S 5$ ) $^{933}$.

For all cases raising these issues the Government submitted to the Committee of Ministers a detailed account on how provisions of the new Code of Criminal Procedure would eradicate the identified shortcomings.

As concerns relevant and sufficient grounds for a decision to held one in custody, the new Code gave a thorough explanation of grounds capable to justify this measure. The concept is that burden of proof of such grounds is on prosecution.

In one of the latest meetings of the CoM in this respect the Committee mentioned that the adopted legislative measures appear to be promising, however an in-depth evaluation of the developments which have taken place would be preferable. There is no comprehensive information on relevant changes in the administrative practice and as regards an impact assessment of the functioning of the new Code in practice. As was mentioned by the Committee, updated information was still required as regards the state of implementation of the entire reform strategy (including on the monitoring of the domestic courts' practice).

The quasi-pilot judgment in the case of Balitskiy v. Ukraine ${ }^{934}$ limelighted on additional problems in the area of guarantees in criminal proceedings. The applicant was convicted on the basis of selfincriminating statements made in the absence of a lawyer whilst being arrested for an administrative offence. The Court condemned the practice of placing a person under administrative arrest to ensure his/her availability for questioning as a criminal suspect, which it had previously found in other Ukrainian cases to be contrary to requirements of Article 5 of the Convention.

The Court further noted that the initial classification of the crime as a simple murder rather than a qualified murder (murder for profit) had allowed the investigation to avoid the requirement of the obligatory legal representation. It reminded that it had examined similar allegations in previous cases against Ukraine "in which the circumstances give rise to strong suspicion as to the existence of an ulterior purpose in the initial classification of the offence and the applicants were effectively denied appropriate legal assistance owing to the way in which the investigator exercised his discretionary power concerning the classification of the investigated crime". This artificial degrade of severity of the offence in order to classify it under an provision of the Criminal Code which would not require obligatory legal representation of the suspect, made the Court to invite the authorities to address this malpractice in specific reforms to avoid further repetitive complaints of this type.

In their submissions to the Committee of Ministers the Government of Ukraine stressed that the new Code of Criminal Proceedings clearly provides that evidence obtained from a witness later acknowledged a suspect in the criminal proceedings are to be declared inadmissible and excluded from evidence data. What is more, the mere notion of "voluntary surrender" (явка з повинною) was removed from the criminal procedure, which makes a practice of keeping a one in administrative detention as a pretext for his/her questioning as a suspect merely useless ${ }^{935}$. It is to be noted that

$933 \mathrm{http}: / /$ www.coe.int/t/dghl/monitoring/execution/Reports/pendingCases_en.asp?CaseTitleOrNumber=Kharche nko\&StateCode $=\&$ SectionCode $=$

934 no. 12793/03, 3 November 2011. 
the new Code for the first time introduced a procedure of declaring evidence inadmissible and its further exclusion.

Personally, I consider the new Code of Criminal Procedure to be one of the biggest success the Council of Europe bodies, including primarily the Court, reached for the legal order in Ukraine. It worth mentioning that up to November 2012 Ukraine had the Code of Criminal Procedure drafted in 1960 (although amended on numerous occasions) for a completely different country USSR with a completely different legal ideology. Although important changes introduced to the Code in 2001 significantly extended application of adversarial principle in criminal proceedings, Ukrainian criminal process still remained influenced by its "Soviet" heritage. Moreover, some "progressive" features of adversarial proceedings were artificially incorporated into existing machinery, which thus did not function as an integral process.

Yet, more than one-year experience of application of the new Code in Ukraine demonstrated that it is not easy to embody even the best imaginable new law into social relations existing for decades. The real reforms take time, and close cooperation with the ECtHR, hopefully, can assist in prompt positive changes.

\subsubsection{Ill-treatment of detainees}

Additional demand to "urgently put in place specific reforms in the legal system» was made in another quasi-pilot judgment in the case of Kaverzin v. Ukraine ${ }^{936}$, where the Court, being struck by a number of cases of ill-treatment by police and ineffective investigation in this respect, ordered "to ensure that practices of ill-treatment in custody are eradicated, that effective investigation is conducted in accordance with Article 3 in every case where an arguable complaint of ill-treatment is raised". The Court mentioned that "the above-mentioned violations were neither prompted by isolated incidents, nor were attributable to a particular turn of events, but were the consequence of regulatory shortcomings and the administrative conduct of the authorities with regard to their obligations under Article 3 of the Convention". Referring to the Ukrainian Ombudsman's reports the Court mentioned that "the evaluation of police officer's work based on the number of solved crimes has been one of the factors contributing to the use of torture against criminal suspects". The Court further pointed out "double role" of the prosecutors in criminal trials, who both prosecute on behalf of the State and supervise of the lawfulness of pre-trial investigations. These conflicting tasks, according to the Court's findings, explain the prosecutors' reluctance to investigate complaints of ill-treatment - since usually criminal suspects are ill-treated with the aim of extracting a confession - which, quite unfortunately, remains the "queen of proof" as of Vyshynskiy time, "it cannot be ruled out that prosecutors have not been interested to conduct full-scale investigations that would be potentially capable of undermining the reliability of such evidence". Given the fundamental value of prohibition of ill-treatment in a democratic society, the Court called "for the prompt implementation of comprehensive and complex measures".

Provisions of the new Code of Criminal Procedure which envisage an obligation to open criminal investigation each time when there is a suspicion that a criminal offence has been committed, is an extremely positive step ahead in this respect. This development appears to solve a persistently found problem in cases against Ukraine - numerous refusals by the prosecuting authorities to institute proceedings following complaints about ill-treatment. Removal, as mentioned above, of a "voluntary surrender" from criminal proceedings and establishing a procedure to declare evidence inadmissible (for instance evidence obtained with a violation of defence rights) should also significantly diminish flagrant practice of ill-treatment.

\footnotetext{
935 Revised action report - Communication from Ukraine concerning the case of Balitskiy against Ukraine https://wcd.coe.int/ViewDoc.jsp?id=1999867\&Site=COE\&BackColorInternet=C3C3C3\&BackColorlntranet=EDB 021\&BackColorLogged=F5D383

936 no. 23893/03, 15 May 2012.
} 
For the moment, this is the only pilot judgment on ill-treatment in the history of the Court.

\subsubsection{Accountability of judges}

One of the most important judgments against Ukraine was the recent case of Oleksandr Volkov $v$. $U_{k r a i n e}{ }^{937}$, as it touched upon the central issue of the whole system of human rights protection independence of judiciary.

The case of Oleksandr Volkov is crucial primarily due to the fact that for the first time the Court has conducted an elaborate study of the system of dismissal of judges which existed in a State. Given its utmost importance for a democratisation process in Ukraine l'll address it in more details.

The case was brought by a former Supreme Court judge, who was dismissed following a procedure that violated, as established by the Court, both Article 6 and Article 8 of the Convention. In particular, the applicant was dismissed for a "breach of oath", which was not sufficiently detailed in the domestic law at the material time. The text of judicial oath itself, as noted by the Court, "offered wide discretion in interpreting the offence of "breach of oath". Pleading before the Court, the Government submitted that the relevant legislation had been amended shortly afterwards. Interestingly, given the significance of the issue, the Court even exceeded scope of the case and, referring to the "new legislation [which] now specifically deals with the external elements of that offence", said obiter dictum, that "while the new legislation did not apply to the applicant's case, it is relevant to note that the specification of "breach of oath" in that section still provides the disciplinary authority with wide discretion on this issue..."

The Court further noted a political interference in the dismissal of judges in Ukraine. It doubted independence of judges of the Highest Administrative Court of Ukraine which reviwed decisions of the High Council of Justice and the Parliament, since these judges

\footnotetext{
"were also under the disciplinary jurisdiction of the HCJ. This means that these judges could also be subjected to disciplinary proceedings before the HCJ. Having regard to the extensive powers of the HCJ with respect to the careers of judges (appointment, disciplining and dismissal) and the lack of safeguards for the HCJ's independence and impartiality..., the Court is not persuaded that the judges of the HAC considering the applicant's case, to which the HCJ was a party, were able to demonstrate the "independence and impartiality" required by Article 6 of the Convention".
}

In this respect a detailed analysis by the Court of independence and impartiality of the High Council of Justice - the first and key body in a procedure of bringing a judge to accountability - is of interest.

Referring to the European Charter on the statute for judges, the Court noted that «with respect to disciplinary proceedings against judges, the need for substantial representation of judges on the relevant disciplinary body has been recognised». At the same time, given the state of legislation at the material time, "the applicant's case was determined by sixteen members of the HCJ ..., only three of whom were judges».

Notably, the Government again refereed to the relevant amendments in the "Law on High Council of Justice" adopted shortly after the events in question, according to which ten members of the HCJ should be appointed from the judicial. Here once more, although these amendments did not affect the applicant and the Court could merely ignore them, considering significance of the matter the Court took the liberty of saying obiter dictum:

"In any event, [these amendments] are insufficient, as the bodies appointing the members of the HCJ
remain the same, with only three judges being elected by their peers. Given the importance of reducing
the influence of the political organs of the government on the composition of the HCJ and the necessity
to ensure the requisite level of judicial independence, the manner in which judges are appointed to the
disciplinary body is also relevant in terms of judicial self-governance. As noted by the Venice

937 no. 21722/11, ECHR 2013. 
Commission, the amended procedures have not resolved the issue, since the appointment itself is still carried out by the same authorities and not by the judicial corps".

Under Article 46 of the Convention the Court noted that the case disclosed "serious systemic problems as regards the functioning of the Ukrainian judiciary. In particular, the violations found in the case suggest that the system of judicial discipline in Ukraine has not been organised in a proper way, as it does not ensure sufficient separation of the judiciary from other branches of State power. Moreover, it does not provide appropriate guarantees against abuse and misuse of disciplinary measures to the detriment of judicial independence, the latter being one of the most important values underpinning the effective functioning of democracies".

Ukraine was urged to take general measures aimed at reforming the system of judicial discipline, including legislative reform involving the restructuring of the institutional basis of the system.

Quite apart from the above mentioned legal topic, the judgment in Oleksandr Volkov case asserted influence on the Ukrainian political life due to a one long-discussed in the Ukrainian society issue. $\mathrm{Mr}$ Volkov claimed that whilst dismissing him the Parliament abused the electronic voting system. He argued that during the plenary vote on his dismissal some members of Parliament had unlawfully cast votes belonging to other members of Parliament who had not been there. His complaint was supported by the video of the plenary meeting of Parliament and by the statements of four members of Parliament certified by a notary.

The Court found that "the decision on the applicant's dismissal was voted on in the absence of the majority of the members of Parliament. The MPs present deliberately and unlawfully cast multiple votes belonging to their absent peers. The decision was therefore taken in breach of [relevant legislation], requiring that members of Parliament should personally participate in meetings and votes". Therefore, the principle of legal certainty had been undermined, in breach of Article $6 \S 1$ of the Convention.

The Court thus drawn down the curtain in a painful point of the legislative process - it was wellknown and widely criticised in the society that majority of laws were voted for in the same way, i.e. when one MP pressed several voting buttons using voting carts belonged to his or her absent peers.

Following judgment in the Oleksandr Volkov case, in February 2013, the Ukrainian Parliament introduced necessary amendments to the Law on the Rules of Procedure of the Verkhovna Rada of Ukraine. The changes were also introduced to a system of tracking violations of the personal voting rule, and in case of a violation the voting card of an absent MP shall be forfeited.

This positive development slackened tension in the Ukrainian society which found ignominious the very fact that the law-makers themselves bluntly violate law.

\subsubsection{Freedom of assembly}

Significance of the quasi-pilot judgement in the case of Vyerentsov $v$. Ukraine 938 for a democratic process can hardly be overestimated. The Court found violations of Articles 11 and 7 of the Convention which stem from a legislative lacuna concerning freedom of assembly in Ukraine. In this case the applicant was arrested for breach of procedure for holding demonstration, regardless an absence of domestic legislation establishing such procedure. The Court noted that the domestic judicial authorities relied on a relevant Decree on the procedure for organising and holding meetings, rallies, street marches and demonstrations in the USSR of 1988, which provided, as was confirmed in the practice of the domestic courts, for a different procedure from the one outlined in the Constitution:

"Indeed, whilst the Ukrainian Constitution requires advance notification to the authorities of an intention to hold a demonstration and stipulates that any restriction thereon can be imposed only by a

938 no. 20372/11, 11 April 2013. 
court, the 1988 Decree, drafted in accordance with the Constitution of the USSR of 1978, provides that persons wishing to hold a peaceful demonstration have to seek permission from the local administration which is also entitled to ban any such demonstration. From the preamble of the Decree it is clear that it had been intended for a very different purpose, namely for only certain categories of individuals to be provided by the administration with facilities to express their views in favour of a particular ideology, this in itself being incompatible with the very essence of the freedom of assembly guaranteed by the Ukrainian Constitution and the Convention. As found by a domestic court ..., demonstrations under the 1988 Decree were considered on the basis of their compatibility with "nonexistent constitutions of non-existent subjects".

The Court further accepted "that it may take some time for a country to establish its legislative framework during a transitional period", however a delay of more than twenty years was not justifiable, "especially when such a fundamental right as freedom of peaceful assembly is at stake". The Court concluded that the interference with the applicant's right to freedom of peaceful assembly was not prescribed by law.

In its judgement the Court referred to the data of the Ukrainian Helsinki Human Rights Union, according to which in 2012 the Ukrainian authorities sought to restrict peaceful gatherings in 358 cases and in $90 \%$ of the cases they succeeded.

Under Article 46 the Court stressed that "specific reforms in Ukraine's legislation and administrative practice should be urgently implemented in order to bring such legislation and practice into line with the Court's conclusions in the present judgment and to ensure their compliance with the requirements of Articles 7 and 11 of the Convention".

In order to enforce this Court's judgment, in July 2013 a group of MPs from several political factions submitted to the Parliament a draft law "On Peaceful Assembly". The draft law waits for its examination.

\subsubsection{Hindrance with the right to submit an application to the Court}

The case of Vasiliy Ivashchenko v. Ukraine ${ }^{939}$ concerned, among others, the authorities' failure to comply with their obligation under Article 34 to provide the applicant with all necessary facilities in order to ensure an effective examination of his application by the Court. In particular, the applicant, who was in detention, was not provided with copies of necessary documents to prove allegations of violations of the Convention which he claimed before the Court. The Court found that "the issue resulted from the absence of a clear and specific procedure enabling prisoners to obtain copies of case documents, either by making such copies themselves, by hand or using relevant equipment, or having the authorities make copies for them. While there were domestic regulations providing for public access to documents kept by the authorities, including court case files, the national judicial authorities did not consider themselves under an obligation to assist prisoners, taking into account their specific situation, in obtaining such copies".

Under Article 46, the Court held that this constituted a systemic problem and considered that adequate legislative and administrative measures should be taken without delay by Ukraine in order to ensure that those who are deprived of their liberty have effective access to documents necessary for substantiating their complaints before the Court.

\subsection{Other important judgments which made a difference}

\subsection{1. conditions of detention}

Although there was no pilot case on conditions of pre-trial detention in Ukraine, the Court has addressed this issue in more than 40 judgments and found a violation of Article $3^{940}$.

939 no. 760/03, 26 July 2012 
The cases revealed poor material conditions of detention in police departments (ITT), pre-trial detention centres (SIZO) and prisons, largely resulting from severe overcrowding, lack of hygiene and sanitation facilities, ventilation, access to natural light and fresh air. In some cases the Court has also found lack of adequate medical treatment precisely for tuberculosis, HIV and hepatitis (led in some cases to death of prisoners ${ }^{941}$ ). The Court has also stressed appalling conditions of detainees' transportation to and from detention facilities both by road and rail. In many cases the Court relied on reports of the Committee for the Prevention of Torture and Inhuman and Degrading Treatment (CPT) which up to the present time has carried out eleven visits to Ukrainian detention facilities.

Finally, absence of effective domestic remedies to complain about these violations and to obtain redress was found to be in violation of Article 13.

Obviously, all mentioned problems are of structural nature. Thus a comprehensive reform of the penitentiary system is necessary as soon as possible. It follows from the reports of Ukrainian government to the Committee of Ministers that, in particular as concerns ITT "since 2006, the Ministry of the Interior has been implementing a programme on construction, reconstruction, repair of police detention facilities aimed, inter alia, at solving the problem of overcrowding and poor sanitary conditions" 942 .

Furthermore, the amendments introduced to the Code on Execution of Sentences in 2010 set a norm of personal space of at least $4 \mathrm{~m} 2$ per prisoner as of January 2012. Some construction works and repairs were done through these years in different facilities. It is also argued that the new Code of Criminal Procedure, with its wide range of preventive measures and strict requirements for application of pre-trial detention, significantly discharged Ukrainian SIZOs (by more than $30 \%$ already in 2013).

Regarding medical assistance in detention, a priority strategy was elaborated by the Penitentiary Department "for curbing the spread of the HIV virus". Furthermore, on 10 February 2012 a joint Order of the Ministry of Justice and the Ministry of Health Protection "On co-operation of medical facilities of the State Penitentiary Service of Ukraine with healthcare institutions as regards medical treatment of detainees" was adopted, setting up procedures of primary medical examination of persons to be placed in penitentiary facilities, their treatment while in detention, emergency medical aid and post-release treatment ${ }^{943}$.

Unfortunately, the Court's findings under Article 13 - lack of effective domestic remedies for complaints about detention conditions - remained unanswered. Although Ukrainian legislation does not preclude the courts from allowing some financial reimbursement ${ }^{944}$, the national courts remain reluctant in granting compensation to detainees for their anguishes.

\subsection{2. detention pending extradition}

Many Court's findings are still waiting for their implementation. In fact, the proceedings before the Committee of Ministers were completed as the necessary general measures were undertaken concerning only several groups of cases against Ukraine.

\footnotetext{
940 see, among many others and most recent, Gorbatenko v. Ukraine, no. 25209/06, 28 November 2013, Vitkovskiy v. Ukraine, no. 24938/06, 26 September 2013.

941 see Kats and Others v. Ukraine, no. 29971/04, 18 December 2008 and Salakhov and Islyamova v. Ukraine, no. 28005/08, 14 March 2013.

942 http://www.coe.int/t/dghl/monitoring/execution/Reports/pendingCases_en.asp?CaseTitleOrNumber=meln ik\&StateCode $=\&$ Section Code $=$

943 Ibid.

944 see, for example, the case of Sizarev v. Ukraine (no. 17116/04, 17 January 2013) where the domestic judicial authorities admitted that the applicant had suffered inhuman and degrading treatment on account, in particular, of the poor conditions of his detention and provided him with a compensation
} 
A group of cases concerning extradition can serve a successful example. In 2008, in the case of Soldatenko v. Ukraine ${ }^{945}$, the Court found that there is no provision in the legislation, which would cover keeping in detention a person, in respect of whom the extradition request is pending. In two years, the relevant amendment to the CCP entered into force. The new legislation set up a detailed procedure for arrest and detention with a view to extradition. It established rules on apprehension, provisional arrest and arrest upon obtaining an extradition request, grounds and time-limits for detention pending extradition, provided for an appeal procedure.

The Court already had an opportunity to examine this new legislation for the purposes of Article $5 \S$ 1 (f) of the Convention and found it "to be sufficiently clear and precise, while their accessibility was not questioned by the applicant" ${ }^{\prime 946}$.

\subsection{3. right of appeal in cases related to administrative offences}

Another group of cases for which general measures were implemented concerned impossibility to challenge a verdict in cases of administrative offence, which are criminal in the autonomous meaning of the Convention, contrary to requirements of Article 2 of Protocol No.7 to the Convention ${ }^{947}$ . The relevant changes to the Code on Administrative Offences were introduced in 2008. This example could be mentioned as a successful one, had the legislator made a one step ahead and recognized that, if majority of the offences which are administrative under Ukrainian law are criminal according to the Convention, quite apart from the requirements of Article 2 of Protocol No.7, an accused in such administrative proceedings should be given all procedural guarantees envisaged in Article 6 of the Convention for criminal proceedings. Amendments to this effect could prevent the Court from finding relevant violations in subsequent cases. Unfortunately that was not done, and in further cases the Court found violations of Article 6. Thus, in the case of Kornev and Karpenko v. Ukraine ${ }^{948}$, a violation of the applicant's right to a fair trial in the administrative (criminal according to the Convention) proceedings was found on account of the fact that she was not afforded adequate time and facilities for the preparation of her defence (violation of Article $6 \S 1$ taken together with Article $6 \S 3$ (b).).

\subsection{4. force-feeding}

In the case of Nevmerzhitskiy v. Ukraine ${ }^{949}$ the Court found the procedure prescribed in the relevant Decree of the Ministry of Internal Affairs for force-feeding of detained persons who go on hunger strike, namely the restraints applied - handcuffs, a mouth-widener, a special rubber tube inserted into the food channel - in the event of resistance, with the use of force, amounted to torture within the meaning of Article 3 of the Convention, if there is no medical necessity. This decree was replaced by another one in 2000, which also does not appear to satisfy fully requirements of Article 3 of the Convention, and was finally quashed in 2013.

\subsection{5. freedom of assembly and association}

The Law of Ukraine "On Public Associations", adopted in 2012, became a significant achievement for democratization process in Ukraine. This law had been developed and promoted during several years by some NGOs following the Court's judgment in the case of Koretskyy v. Ukraine ${ }^{950}$.

\footnotetext{
945 Soldatenko v. Ukraine, no. 2440/07, 23 October 2008

946 Molotchko v. Ukraine, no. 12275/10, § 166, 26 April 2012

947 see, Gurepka v. Ukraine, no. 61406/00, 6 September 2005

948 no. 17444/04, 21 October 2010.

949 no. 54825/00, ECHR 2005-II (extracts).

950 no.40269/02 03 April 2008.
} 
This case concerned a violation of the applicants' right to freedom of assembly due to the authorities' refusal to register their association on the ground that its articles had not been drafted in accordance with domestic law. The City Department of Justice stated that an association did not clearly indicate if it had a local or a all-Ukrainian status; that an association could not carry out publishing activities on its own, publicise its activities, lobby the authorities about environmental protection, or carry out expert examinations in this field; that the managing board of an association was not entitled to exercise everyday administrative functions and that the association could not engage volunteers as members of the association. After unsuccessful attempts to challenge that decision before the domestic judicial authorities, the applicant lodged the case before the ECtHR. The Court found a violation of Article 11 of the Convention, having stated that the provisions of the Associations of Citizens Act, which regulated the registration of associations at the material time, were too vague to be sufficiently "foreseeable" and granted an excessively wide margin of discretion to the authorities to decide whether a particular association could be registered. The Court has also found little justification for then existing restrictions on the possibility for associations to publish and distribute propaganda, to involve volunteers as members, or to carry out everyday activities through a managing body. As concerns the territorial limitation of the activities of associations with local status, the Court considered as burdensome the requirement for associations wishing to have a panUkrainian status, to set up local branches in the majority of the twenty-five regions of Ukraine.

It appears that the Law adopted in 2012 eliminated the above-mentioned problematic aspects of the previous legislation on the issue.

Thus it clearly provides for only two grounds for refusal of registration - if provisions of the articles of association or other documents submitted for the registration contravene the Constitution of Ukraine or other requirements of the said Law concerning founders of an association and its name. The Law does not contain restrictions as regards involving volunteers as members, or a possibility for a managing body to determine an association's everyday activities.

\section{The influence of the case-law in relation to Ukraine on the Court's jurisprudence}

On its turn, Ukrainian practice also enriched the case-law of the Court.

In one of the first judgments against Ukraine, Sovtransavto Holding v. Ukraine ${ }^{951}$, the Court for the first time formulated a general rule concerning the positive obligation of a State as regards the protection of property: "[t]he States are under an obligation to afford judicial procedures that offer the necessary procedural guarantees and therefore enable the domestic courts and tribunals to adjudicate effectively and fairly any disputes between private parties"952. In this case the Court found a number of 'very serious procedural shortcomings, including interventions of the State executive branch into the relevant proceedings and considered that they were ipso facto incompatible with the notion of an 'independent and impartial tribunal'. Thus the Court introduced this positive obligation by an analogous way it has done so in cases not concerning protection of property.

In another important case Editorial Bord of Pravoye delo and Shektel v. Ukraine ${ }^{953}$, which concerned an order to a newspaper to pay damages for having published an anonymous letter found on the Internet, the Court imposes a positive obligation on States to set up an appropriate legislative framework to protect journalists' freedom of expression on the Internet.

\footnotetext{
951 no. 48553/99, ECHR 2002-VII

952 Prior to this judgment the same approach was implicitly used once in the case of Hentrich v. France where the proportionality issue was linked to procedural elements since the applicant was refused the possibility "of effectively challenging the measure taken against her" - see D.Popovic, Protecting Property in European Human Rights Law, Eleven International Publishing, p.118.

953 no. 33014/05, ECHR 2011 (extracts)
} 
The judgment in the case of Savitskyy v. Ukraine ${ }^{954}$ complements to the case-law on the procedural limb of Article 3. The Court stated that the State's procedural obligations to ensure the effective participation of the victim in the investigation of his complaints of ill-treatment means that he or she must be provided with an effective access to free legal representation.

In the above-mentioned judgment in the case of Oleksandr Volkov v. Ukraine ${ }^{955}$ the Court required the State, in the operative provisions, to reinstate the applicant in his post as a Supreme Court judge or an equivalent post - and this was a rather innovative step in application of the principle of restitution in integrum by the Court.

The case of Nataliya Mikhaylenko v. Ukraine ${ }^{956}$ concerned lack of access to court for person seeking restoration of his/her legal capacity. Whilst in Stanev v. Bulgaria ${ }^{957}$ the Grand Chamber interpreted Article $6 \S 1$ as guaranteeing that anyone who had been declared partially incapable had direct access to a court to seek restoration of his or her legal capacity, in the said Ukrainian case this guarantee was expanded to those declared fully incapable.

It also appears that the adopted judgments in the cases of Lutsenko v. Ukraine ${ }^{958}$ and Tymoshenko $\mathrm{v}$. Ukraine ${ }^{959}$, as well as a number of pending cases against former governmental officials, are called upon to clarify requirements of Article 18 of the Convention which for the moment remains a grey area in the Court's case-law.

Hence, in the case of Mr Lutsenko - a well-known opposition leader and ex-Minister of Interior, violation of Article 18 in conjunction with Article 5 was found because the prosecuting authorities seeking the applicant's arrest explicitly indicated the applicant's communication with the media as one of the grounds for his arrest, and thus the restriction of the applicant's liberty permitted under Article $5 \S 1$ (c) was applied not only for the purpose of bringing him before the competent legal authority on reasonable suspicion of having committed an offence, but also for other reasons. Similarly, in the case of Mrs Tymoshenko, the former Ukrainian Prime Minister, the purpose of the applicant's detention was to punish the applicant for a lack of respect towards the court which it was claimed she had been manifesting by her behavior during the proceedings. Consequently, the restriction of the applicant's liberty permitted under Article $5 \S 1$ (c) was applied for a wrong reason.

\section{Impact of the Court's jurisprudence on national jurisdictions}

\section{1. the Constitutional Court of Ukraine}

Researches and judges of the Constitutional Court of Ukraine (CCU) indicate that there are three ways by which the CCU applies the ECtHR's case-law ${ }^{960}$. In some judgments the CCU whilst substantiating its own legal position merely mentions that there are some international standards in this respect without further specification. It should be noted that this technique is not emblematic any more in recent years. For instance, in the case on independence of judges as part of their status ${ }^{961}$ the Constitutional Court stated that its approach to the issue of judicial independence is also enshrined in the Convention and other international documents, and is also confirmed by the Court's case-law. No further references - to the provisions of the Convention or the Court's judgments - were made.

\footnotetext{
954 no. 38773/05, 26 July 2012

955 no. 21722/11, ECHR 2013

956 no. 49069/11, 30 May 2013

957 no. 36760/06, ECHR 2012

958 no. 6492/11, 3 July 2012

959 no. 49872/11, 30 April 2013

960 Gultay M. Impact Of The European Court On Human Rights Case-Law On Constitutional Jurisprudence: Ways Of Optimization With Further References

961 Decision no. 19-pп/2004 of 01.12.2004.
} 
The second way is more prevailing - the CCU invokes concrete provisions of the Convention and refers to the most well-known judgments of the Court without, however, a detailed analysis of the Court's legal position. Thus, in the case upon the constitutional petition of the Board of the Pension Fund of Ukraine, concerning official interpretation of the legislative provisions on a possibility to change a scale of social benefits depending on social economic capabilities of state ${ }^{962}$, the Constitutional Court stated that "the European Court of Human Rights in its judgment of 9 October 1979 in the case of Airey v. Ireland also held that social and economic rights largely depended on the situation in the states, especially financial. These postures apply as well to the issues of acceptability of reduction of social benefits, as stated in the judgment of this Court in the case of Kjartan Ásmundsson v. Iceland of 12 October 2004". This brief reference to the Court's judgments without further precision was criticized by the dissenting judge in his separate opinion, according to which the above mentioned judgments "concerned different casual aspects". Having explaining ratio decidendi of these judgments, the dissenter came to a conclusion that they "by no means could be used as an appropriate argumentation for completely different stance of the Constitutional Court of Ukraine". Without interfering into this legal dispute one can just note that a well-defined analysis of the Court's case-law would furnish legitimacy of the Constitutional Court's position in a specific case.

And that represents the third way of application of the Court's case-law by the Constitutional Court in its decisions. In past years the CCU more and more often resorts to an assessment of the Court's conclusions in different cases on a content and scope of a particular Conventional provision or particular legal guarantee.

In the case concerning conformity with the Constitution of Ukraine of some provisions of the Code of Administrative Offences and the Law of Ukraine "On Militia" on terms of the administrative arrest ${ }^{963}$ the Constitutional Court referred to its interpretation of the principle of legal certainty, according to which it is one of the elements of the rule of law which states that restriction of the fundamental human rights and are acceptable only if application of the relevant legal provisions is foreseeable. In other words, restriction of any right should be based on the criteria which provide a person with a possibility to distinguish lawful behavior from an unlawful one. The CCU referred to the cases of Baranowski v. Poland and Novik v. Ukraine where the Court recalled that where deprivation of liberty is concerned, it is particularly important that the general principle of legal certainty is satisfied. It also relied on the case of Soldatenko v. Ukraine in which the Court held that "In laying down that any deprivation of liberty must be effected "in accordance with a procedure prescribed by law", Article $5 \S 1$ does not merely refer back to domestic law.., it also relates to the "quality of the law", requiring it to be compatible with the rule of law... "Quality of law" in this sense implies that where a national law authorises deprivation of liberty it must be sufficiently accessible, precise and foreseeable in its application, in order to avoid all risk of arbitrariness". Basing on these arguments the CCU concluded that the impugned provisions did not satisfy requirements of "legal certainty" and thus had to be declared unconstitutional.

In the case concerning official interpretation of the provision of Article 62.3 of the Constitution of Ukraine that "accusation shall not be based on illegally obtained evidence" 964 , the CCU referred to cases of Teixeira de Castro v. Portugal and Shabelnik v. Ukraine. It found that a conviction shall not be based on any information or evidence obtained as a result of operative and investigation activity by the authorised person contrary to the constitutional provisions or in violation of the procedure envisaged by the law, as well as obtained through their collection and fixation by a person, not authorised to perform such activities.

\footnotetext{
962 Decision No. 3-рп/2012 of 25.01.12; see also the separate opinion by Judge Shyshkin annexed to this judgment.

963 Decision no. 10-pп/2011 of 11 October 2011

964 Decision no. 12-rp/2011 of 20 October 2011
} 


\subsection{Courts of general jurisdiction and specialized courts}

As argued above, the Law on Enforcement obliges Ukrainian judges to use the Convention and the Court's case-law in their practice. The Code of Administrative Justice clearly provides that "a court shall apply the principle of the rule of law by taking into account the case-law of the European Court of Human Rights". The same provision was introduced to the new Code of Criminal Procedure "the principle of the rule of law in criminal proceedings shall be applied with due consideration of the practices of the European Court of Human Rights".

According to the Ruling of the Plenary of the Supreme Court of Ukraine of 18 December 2009 "On a judicial decision in a civil case", reasoning part of each judgment should contain, if necessary, a reference to the Convention and the Court's case-law which serves a source of law. The same position was repeated in some other rulings of the Plenary.

The task of summarizing the reception of the Court's practice by national judges in Ukraine is hardly feasible, it varies from a court to a court and from a judge to a judge. Subject matter of each particular case and existence of well-established and translated into Ukrainian the Court's practice is another factor to be taken into consideration.

Thus, for example, an extensive use of the Court's practice can be found in decisions of the domestic courts concerning alleged ill-treatment. Very often courts quash rulings of the prosecuting authorities not to institute criminal proceedings following a complaint about ill-treatment, citing judgments of the Court in cases against Ukraine and explaining what shall be done to have an "effective investigation" into complaint of use of force by the police as developed by the Strasbourg court.

Unfortunately, this courts' stance remained ineffective in a struggle against ill-treatment by police officers, as practice shows that following such decisions the prosecuting authorities continue to evade effective investigation, ignore the courts' instructions and refuse to open criminal proceedings or terminate pending proceedings on the same grounds as found previously inacceptable ${ }^{965}$. The courts then continue to insist on standards of effectiveness, and this "ping-pong" between prosecuting and judicial authorities can last for years. For example, in the case of Vergelskiy v. Ukraine ${ }^{966}$ the prosecutor's decisions not to institute criminal proceedings were quashed 13 times.

Another area in which the Court's case-law is extensively used is defamation claims. Virtually all judgments on defamation in past years refer to Article 10 of the Convention as interpreted by the Court both in judgments against Ukraine and against other States. Interestingly, the very first judgment against Ukraine on Article 10 of the Convention, Ukrainian Media Group v. Ukraine ${ }^{967}$, according to analysts had an instant impact on Ukrainian courts and immediately became an effective way to protect journalists from politicians' lawsuits ${ }^{968}$. In that case the Court found that the sanctions for defamation were disproportionate to the aim pursued as value judgments were not distinguished from statements of facts. The vice-president of the Ukrainian Association of media lawyers in her analysis refers to the defamation case brought by the Regional Governor in which the defendant's arguments concerning wider limit of acceptable criticism with regard to a politician acting in his public capacity than in relation to a private individual were firstly rejected by the presiding judge. However, as soon as the Court's judgment in the Ukrainian Media Group case

965 Пошва Б.М., Касько В.В. Застосування національними судами України положень ЄКПЛ та практики Європейського суду з прав людини у сфері протидії жорстокому поводженню і безкарності. In: Application of European standards for combating ill-treatment and impunity in Ukraine. Scientific and practical manual for judges, 2012.

966 no. 19312/06, 12 March 2009

967 no. 72713/01, 29 March 2005

968 Панкратова Людмила. Коментар до рішення Європейського суду з прав людини «Українська пресгрупа проти України». http://www.justinian.com.ua/article.php?id=2863 
appeared, he had changed his mind and dismissed the claim, having referred to Article 10 of the Convention and stated that the disputed information "was a value judgments of the author about the plaintiff, who was a politician and a public figure, and thus had to be more tolerant to the value judgments against him" ${ }^{\prime \prime 69}$.

It appears that after almost nine years since the judgment was passed and many other relevant Court's judgments were translated into Ukrainian and disseminated among the judges, distinction between value judgments and statements of facts does not create any problem.

The Court's case-law is traditionally widely used in the administrative jurisdiction, as it was introduced in 2005 already with an explicit requirement to rely on the Convention.

Two judgments are most cited by the administrative courts up to now - Kechko v. Ukraine ${ }^{970}$ and Shchokin v. Ukraine ${ }^{971}$

The case of Kechko concerns payment of social benefits - the issue generating waste majority of cases before the administrative courts in Ukraine. The Court found that the denial by the domestic authorities of the applicant's entitlement to a benefit, envisaged by law but suspended by a secondary legislation, was arbitrary and not based on the law. The Court considered that the State could introduce, suspend or terminate the payment of benefits by making the appropriate legislative changes. "However, once a legal provision is in force which provides for the payment of certain benefits and the conditions stipulated have been met, the authorities cannot deliberately refuse their payment while the legal provisions remain in force". This Court's finding is widely referred to by administrative courts when they allow claims of plaintiffs whose social benefits were postponed or diminished due to a lack of sufficient budgetary funds.

In the case of Schokin the applicant complained that the tax authorities had unlawfully increased his income tax liability. He argued that the tax rate in respect of the income earned outside the principal place of business had been regulated by three different acts, and the tax authorities arbitrarily relied on less favourable of them. Having reminded that it was primarily for the national authorities to interpret and apply domestic law and assuming that the interpretation by the domestic authorities was plausible, the Court was not satisfied with the overall state of domestic law on the matter in question, given manifest inconsistency of relevant legal acts with each other. The Court came to a conclusion that "the lack of the required clarity and precision of the domestic law, offering divergent interpretations on such an important fiscal issue, upset the requirement of the "quality of law" under the Convention and did not provide adequate protection against arbitrary interference by the public authorities with the applicant's property rights". Thus the Court concluded that the interference with the applicant's property rights had not been lawful for the purpose of Article 1 of Protocol No. 1.

This judgment significantly influenced the administrative jurisprudence in tax matters in Ukraine. The new Tax Code entered into force in 2011and its transitional provisions also permitted controversial interpretations, which allowed tax authorities and subsequently courts to take opposite approaches in similar cases. Eventually, the Highest Administrative Court of Ukraine took the side of tax payers, with a view of position of the Court in Shchokin case and a clear provision of national legislation (also underlined in Shchokin), according to which if the norms of different laws or normative legal acts offer ambiguous or multiple interpretations of the rights and obligations of taxpayers and supervising authorities, the decision taken shall be in favour of the taxpayer ${ }^{972}$.

\footnotetext{
969 lbid.

970 no. 63134/00, 8 November 2005

971 nos. 23759/03 and 37943/06, 14 October 2010

972 A.V. Soloviov, P.M. Rabinovich / Influence of the ECHR case-law on domestic jurisprudence of administrative courts in Ukraine // Legal Ensuring of the Effective Execution Of Judgments And Implementation of Practice of the European Court of Human Rights: Materials of scientific articles of the Second International
} 
Some other Court's judgments in tax matters are successfully used by Ukrainian taxpayers in their litigations. Administrative courts quash rulings of Tax Administration imposing fines on legal entities for alleged breach of VAT obligations by their business partners. Apart from relevant norms of Ukrainian legislation the courts refer to the Court's findings in the cases of Intersplav v. Ukraine ${ }^{973}$ and "Bulves" $A D$ v. Bulgaria974, where it was stated that if State authorities possess any information about abuse of the VAT refund system by a concrete entity, they can apply appropriate measures to prevent or stop such abuses by this entity and not but its counteragent in the absence of any indication of its direct involvement in such abusive practices ${ }^{975}$. The courts widely rely on the ECtHR's stance as to inability for a company to secure compliance by its counteragent with its VAT reporting obligations whilst there is no fraud in relation to the VAT system of which a company had knowledge or the means to obtain such knowledge ${ }^{976}$.

Application of the Court's jurisprudence in criminal matters is less extensive, although there is, of course, a growing knowledge among judges about the Court's interpretation of procedural guarantees under Article 6 of the Convention. Nevertheless, in increasing number of cases courts of appeal and cassation quash first-instance courts' judgments since rights of convicts for legal representation or interrogation of witnesses were not sufficiently respected.

Some curiosity examples also take place. For instance, having found that a drug-related offence was provoked by police officers, one of the Ukrainian courts referred to the judgment in the case of Texiera de Castro v. Portugal ${ }^{977}$ and considered the fact of entrapment as a "mitigating circumstance" for the purpose of sentencing ${ }^{978}$.

It appears that with a turn from partly inquisitorial criminal process, existed in Ukraine prior to November 2012, into adversarial one judges will more and more have recourse to the Convention.

One more issue worth mentioning in this part of the paper. The most problematic aspect in the Court's jurisprudence for comprehension and use by Ukrainian judges is the requirement of proportionality of interference, inherent in the Convention. Several years ago my learned colleague judge Angelika Nussberger wrote that "[t]he decisions of the Ukrainian Constitutional court are not yet as refined as to have resort to the proportionality test. As a rule, a large number of constitutional provisions are quoted to prove constitutionality or unconstitutionality without going into the details of interpretation". ${ }^{979}$ Proportionality test is completely unnatural for the Ukrainian legal system (as, in fact, for all post-communist systems). Although the requirement to analyze proportionality of interference is contained in the Code of Administrative Justice, virtually no administrative court judgment with such an analysis can be found. The courts mostly restrict their examination of the case to the issue of legality of interference only, even when circumstances of the case and the Convention's requirements clearly call for a further study if an interference was proportionate toward the legitimate aim pursued. It appears that more attention to this subject should be paid during numerous legal trainings.

\footnotetext{
Scientific Conference / National University «Odessa Law Academy». - Odessa : Feniks, 2013. - 492 P.

973 no. 803/02, 9 January 2007

974 no. 3991/03, 22 January 2009

975 See among others judgment of the Odessa County Administrative Court of 12 August 2012, http://reyestr.court.gov.ua/Review/17773582.

976 See, for example, judgment of the Mykolaiv County Administrative Court of 21 February 2012, http://reyestr.court.gov.ua/Review/24395750.

9779 June 1998, Reports of Judgments and Decisions 1998-IV.

978 Judgment of the Belotserkovskiy district court of 19 February 2013.

979 Angelika Nussberger. The Reception Process in Russia and Ukraine, in: Keller/Stone Sweet (eds.), A Europe of Rights. The Impact of the European Court of Human Rights on National Legal Systems. Oxford Press 2008, p. 603-674.
} 


\section{Dissemination of the Court's case-law, teaching and scholarship}

It cannot be said that the Court's jurisprudence is poorly disseminated in Ukraine. All judgments in cases against Ukraine are translated into Ukrainian language and published in the official magazine issued by the Ministry of Justice. From time to time summations of the Court's most important judgments on different topics are prepared by high courts legal officers and distributed among judges. Numerous books and practical guidances to the Convention were published in Ukraine during past years. Major legal magazines devote their articles to diverse aspects of the Court's caselaw.

One can hardly count all seminars, conferences, trainings and study visits for judges, lawyers and prosecutors that were devoted to the Court's work and organized by different international and local bodies (including primarily the Council of Europe) during past fifteen years. These activities continue to attract many participants from all branches of the legal system of Ukraine.

It worth mentioning that questions concerning the Convention and the Court's case-law form integral part of exams necessary to pass for becoming a judge in Ukraine, as well as exams for admission to the Bar. Further obligatory trainings also include this matter. The National School of Judges of Ukraine pays particular attention to judges' awareness of the Convention. Obviously, this work cannot be exhausted and it is necessary to deepen the knowledge of Ukrainian lawyers about human rights and keep them posted on developments in the Court's practice. But it is undisputed that an original "hunger" for information on the European Court of Human Rights which existed some ten years ago is now satisfied.

The Court's case-law has also an impact on the legal scholars' scientific interest. For past years many Doctoral thesis were devoted precisely to the issues related to the Court's jurisprudence and activity ${ }^{980}$

\section{Concluding remarks}

I would dare to argue that the most obvious influence of Ukrainian presence in the Council of Europe and within the Court's jurisdiction is a rise of a strong civil society. The recent events in Ukraine showed that it is capable now to bring the power to accountability using democratic procedures. In fact, the revolution of 2013-2014 was mostly a struggle of a civil society against dictatorship and nepotism. But that became conceivable following years of intensive work of Ukrainian NGOs using, among others, Convention mechanisms, to bring changes to the society still suffering from vicious soviet heritage with its complete disrespect to the rule of law.

Various legal NGOs not only spread information among population on international mechanism of human rights protection, admissibility criteria, other particularities of application to the Court, Court's case-law; they also lobby execution of the Court' judgments thus promoting implementation of the human rights standards.

The Ukrainian Helsinki Union, for instance, created the Strategic Litigations Center in order "to enforce the state, by means of national and international legal mechanisms, to adhere to high human rights standards". The Center "brings together organizational and financial resources of nongovernmental organizations, activists and lawyers in order to strengthen impact of strategic litigations and to change the situation in the country". Cases which can potentially change legislation, administrative or judicial practice in order to improve protection of rights and liberties are considered to be "strategic" ones. Some of these cases were brought to the Court and gave rise

980 Korotkyi T.R./Influenced The Development Of Legal Consciousness Of The European Court Of Human Rights // Legal Provision Of The Effective Execution Of Judgments And Implementation Of The European Court Of Human Rights Practice: Collection Of Scientific Articles Of The International Scientific Conference / National University «Odessa Law Academy». - Odessa : Feniks, 2012. - 520 P. 
to important Court's judgments for the domestic legal order (for example, the above mentioned case of Vyerentsov $v$. Ukraine on freedom of assembly).

Being backed by the international human rights community and elated with many examples of successful litigation before the Court, Ukrainians draw inspiration to stand upon their rights from the very possibility to be heard by this most respected European judicial institution.

Ukrainian legal system is still far from being perfect; it is eroded by contradicting legislation, longstanding flawed administrative practice and high judicial corruption. Each Court's judgment, however, and general measures to be subsequently implemented, is considered a "building block" to this system, and 17 years after joining the Convention are clearly not sufficient to overcome all flows inherited from the communist legal consciousness. Building of a State committed to rule of law is a long travel; we are moving toward this goal and a lot had already been done. The ultimate objective of joining the European system of human rights protection is to form a democratic constitutional state in reality and not on paper. And a strong civil society, inspired by the Court's standards, is the biggest Ukrainian achievement of being a part of the European family, particularly being under jurisdiction of the European Court of Human Rights. 